\title{
-
}

(liner: 2an The Arctic rint Prainies

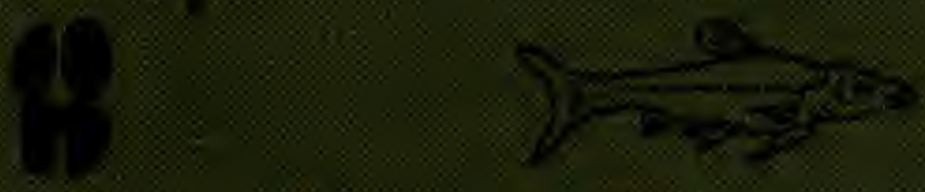

\section{Ernest Thompson Seton}

(1) $y$

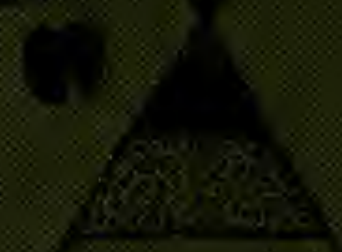

$x$

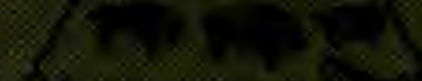

chers.

extoris 

0.1

के 



\title{
The Arctic Prairies
}

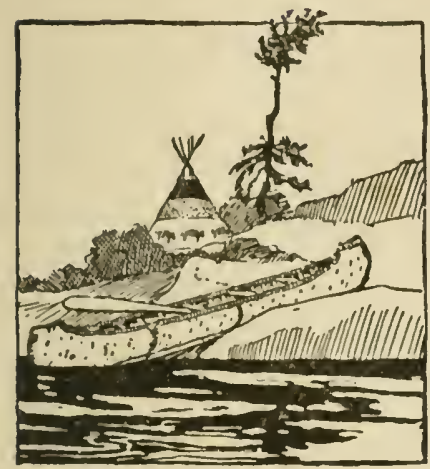

\author{
A Canoe - Journey \\ OF 2,000 MILES IN SEARCH \\ OF THE CARIBOU
}

BEING THE ACCOUNT OF A VOYAGE TO THE REGION NORTH OF AYLMER LAKE

By Ernest Thompson Seton Author of "Wild Animals I Have Known". "Life Histories"Etc

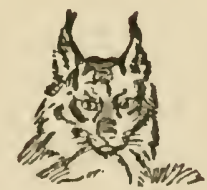

PUBLISHED·BY·CHARLES SCRIBNER'S SONS. NEW YORK CITY·A·D·1920 
Copyright, 1911 , by

Ernest Thompson Seton

First Edition

First Impression

November 16. 1911

Second Impression

February 26, 1912

New Uniform Edition

First Impression

August 18, 1917

Second Impression

May 24, 1920 


\section{DEDICATED}

TO

THE RIGHT HONOURABLE

SIR WILFRID LAURIER, G. C. M. G.

PREMIER OF CANADA 



\section{PREFACE}

What young man of our race would not gladly give a year of his life to roll backward the scroll of time for five decades and live that year in the romantic bygone days of the Wild West; to see the great Missouri while the Buffalo pastured on its banks, while big game teemed in sight and the red man roamed and hunted, unchecked by fence or hint of white man's rule; or, when that rule was represented only by seattered trading-posts, hundreds of miles apart, and at best the traders could exchange the news by horse or canoe and months of lonely travel?

I, for one, would have rejoiced in tenfold payment for the privilege of this backward look in our age, and had reached the middle life before I realised that, at a much less heary cost, the miracle was possible to-day.

For the uncivilised Indian still roams the far reaches of absolutely unchanged, unbroken forest and prairie leagues, and has knowledge of white men only in bartering furs at the scattered trading-posts, where locomotive and telegraph are unknown; still the wild Buffalo elude the hunters, fight the Wolves, wallow, wander, and breed; and still there is hoofed game by the million to be found where the Saxon is as seldom seen as on the Missouri in the times of Lewis and Clarke. Only we must seek it all, not in the West, but in the far North-west; and for "Missouri and Mississippi" read "Peace and Mackenzic Rivers," those noble streams that northward roll their mile- 
wide turbid floods a thousand leagues to the silent Arctic Sea.

This was the thought which spurred me to a sixmonths' journey by canoe. And I found what I went in search of, but found, also, abundant and better rewards that were not in mind, even as Saul, the son of Kish, went seeking asses and found for himself a crown and a great kingdom.

My thanks are due here to the Right Honourable Lord Strathcona, G. C. M. G., Governor of the Hudson's Bay Company, for giving me access to the records of the Company whenever I needed them for historical purposes; to the Honourable Frank Oliver, Minister of the Interior, Canada, for the necessary papers and permits to facilitate scientific collection, and also to Clarence C. Chipman, Esq., of Winnipeg, the Hudson's Bay Company's Commissioner, for practical help in preparing my outfit, and for letters of introduction to the many officers of the Company, whose kind help was so often a Godsend.

Ernest Thompson Seton. 


\section{CON'TENTS AND ILLUSTRA'TIONS}

In addition to the illustrations in the following list there are in this book one hundred and twenty-five drawings in pen and ink including a number of maps.

Preface . . . . . . . . . . . . $\begin{array}{r}\text { Page } \\ \text { vii }\end{array}$ CHAPTER

I. Departure for the North . . . 3

Pierre Powder (It-talı-min-a-hoo) . . 6

John Schott, Caspar IVhitney's guide . 6

II. Down the Noisy River witi tire Vorageurs . . . . . . . 10

E. T. Seton and E. A. Preble leaving Athabaska Landing, May 17, 1907 . 10

Down the Athabaska River . . . 10

I found it was a dead house-cat; . . . under it was a hungry-looking Lynx 12

Our camp above Grand Rapids, Athabaska River . . . . . . . 14

Looking down the Athabaska River from the island in the Grand Rapids 14

III. Human Nature on the River \& . 19

Lobsticks or Monument Trees on the skyline, Athabaska River . . . 20 
CHAPTER

Camp on the Great Slave River

The Hudson's Bay Company convoy descending the Athabaska River . 24

Grand Rapids, Athabaska River . . 24

IV. Down the Silent River with the Mounted Police

The love-song of the Richardson Owl

V. A Conference witi tue Chiefs . . 36

VI. Out with Sousi Beaulieu . . . . 40

VII. The Buffalo Hunt . . . . . . 44

Bear-claw marks on tree . . . . 44

The Buffalo herd disappearing in brush $4 \mathrm{~S}$

VIII. Thomas Anderson . . . . . . 54

Thomas Anderson, Smith Landing, June $11,190 \overline{7}$. . . . . 54

Murdo Mackay, June 9, 1907 . . jt

IX. Mosquitoes . . . . . . . . 61

X. A Bad Case . . . . . . . . 70

XI. The Second Buffalo Hunt . . . 75

The Athabaska Rose or Needle Bloom $\quad 76$

Pierre Squirrel, Chief of the Chipewyans

XII. Bezky and the Pills . . . . . 83 
XIII. Fort Suitil ANd the Social Queen 86 Indian cabin, Fort Smith . . . . SS

Starving squaws looking for the return of the fisher boats . . . . . . 88

XIV. Rabists AND Lrixes in the NorthWEST . . . . . . . 95

XV. Fisis and Flow of Animal Life • . 107

XYI. The P'rican Trip . . . . . . 113

XYII. 'Til: 'Thind Buffalo Hunt . . . . 116

XVIII. Dowy to Fundanentals . . . . 125

XIX. White MiN AND Red. MeAt, BUt Notilng More . . . . 130

X. ON the Niarling . . . . . . 136

July camp on the Great Slave Lake . 136

The Nyarling Tessi or Underground River . . . . . . . 136

XXI. Fort Resolotion and Its Folk . . 143 Sunset on Slave River . . . . . 144 Fort Resolution . . . . . . 144

XXII. The, Chupewans, Them Speecil and Writing . . . . . . . 147

XXIII. The Dogs of Fort Resolution . . 159 XXIV. The Vorage Across the Lake * 169 Our party at Lockliart River . . . 170 
XXV. Crossing the Lake. Its Natural HistorY . . . . . . . . 179

The Japanese landscape about Great Slavc Lake . . . . . . . 182

Dwarf spruce, about four feet ligh, on edge of the Barren-Grounds . . 182

Forcing ice on the Great Slave Lake . 186

The meal at the Lobstick, Pike's Portage . . . . . . . 186

XXVI. The Lynx at Bay . . . . . . 190

Photographing a Lynx . . . . . 192

XXVII. The Last of that Indan Crew . . 193

XXVIII. Geological Forces at Work . . . 197

XXIX. Pike's Portage . . . . . . . 200

The Deathbirds, the Storm, and the Wolverine . . . . . . . 200

XXX. Caribou-Land at Last . . . . 204

XXXI. Good-bye to THe Woods . . . 213

The giants on the edge of the forest . 216 An ancient dwarf about 250 years old. Billy ready for action . . . . 216

XXXII. The Treeless Plains . . . . . 219

Tyrrell's Monument at Last Woods . 220

The falls of the Casba River . . . 220

Spring migration of Caribou . . . 222 
XXXIII. THe UnkNown

A young buck . . . . . . 224.

Caribou with broken leg, in sanctuary 224

Same Caribou (another photo.) . . 224

The leap for life . . . . . . . 226

XXXIV. Aylmer Lake . . . . . . . 228

Caribou enjoying a breeze . . . . 228

The trophy that weighed ninc hundreel pounds . . . . . . . 228

XXXV. The Musk-ox . . . . . . . 231

The head of the Musk-ox . . . . 232

Head of bull Musk-ox-a pencil study 232

Head of a young buck . . . . . 234

An Aretic Fox in his summer coat . . 234

Earl Grey River, looking south-west . 236

XXXVi. The Arctic Prairies and My FarTHEst North . . . . . 237

Getting the first sight of the Musk-ox . 238

The bull turned and faced us . . . 238

Snap-shot taken at fifty yards . . 238

The trout brook back of Tyrrell's

Monument, Last Woods . . . 240

Typical landscape, Arctic Prairies . 240

XXXVII. Facing Homeward . . . . . . 246

XXXViII. The First Woods . . . . . 251

A Wolverine and her cubs stealing our Caribou meat . . . . . . 252 
XL. Old Fort Reliance to Fort ResoLUtion . . . . . . . 263

Xli. Going up the Lower Slave . . . 271

XliI. Fort Suith and the Tug . . . 276 The camp was like a country graveyard . . . . . . . . 276

XLIII. Fort McKay and Jiarobia . . . 281 XliV. The River . . . . . . . . . 285

Xly. The River Shows Its Teeth . . . 289

XlVI. Bright Again . . . . . . . . 296

XlviI. When Nature Simled . . . . 301 XLVIII. 'The End . . . . . . . . . 307 


\section{THE ARCTIC PRAIRIES}





\section{CHAPTER I}

\section{DEPARTURE FOR THE NORTH}

Is 1907 I set out to journey by canoe down the Athabaska and adjoining waters to the sole remaining forest wilds-the far north-west of Canada-and the yet more desert Arctic Plains, where still, it was said, were to be seen the Caribou in their primitive condition.

My only companion was Edward A. Preble, of Washington, D. C., a trained naturalist, an expert canoeist and traveller, and a man of three seasons' experience in the Hudson's Bay Territory and the Mackenzie Valley. While my chief object was to see the Caribou, and prove their continued abundance, I was prepared incidentally to gather natural-history material of all kinds, and to complete the shore line of the ambiguous lake called "Aylmer," as well as explore its sister, the better-known Clinton-Colden.

I went for my own pleasure at my own expense, and yet I could not persuade my Hudson's Bay Company friends that I was not sent by some government, museum or society for some secret purpose.

On the night of May 5 we left Winnipeg, and our observations began with the day at Brandon.

From that point westward to Regina we saw abundant cvidence that last year had been a "rabbit year," that is, a year in which the ever-fluctuating popula- 
tion of Northern Hares (Snowshoe-rabbits or Whiterabbits) had reached its maximum, for nine-tenths of the bushes in sight from the train had been barked at the snow level. But the fact that we saw not one

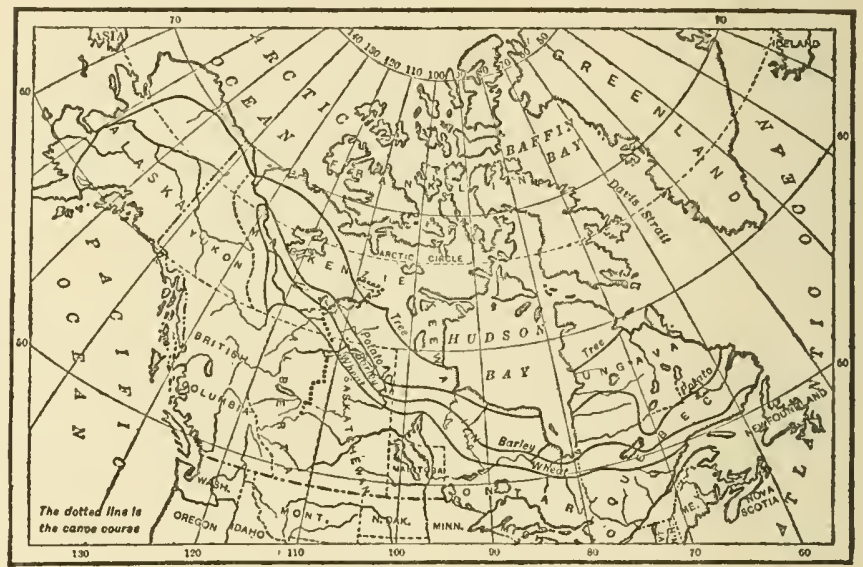

Map showing the north limit of trees and of the successful culture of potatoes, barley, and wheat

The dotted line from the Saskatchewan northward is iny canoe-route

Rabbit shows that "the plague" had appeared, had run its usual drastic course, and nearly exterminated the species in this particular region.

Early next morning at Kininvie (40 miles west of Medicine Hat, Alberta) we saw a band of 4 Antelope south of the track; later we saw others all along as far as Gleichen. All were south of the track. The bands contained as follows: 4, 14, 18, 8, 12, 8, 4, 1, 4, $5,4,6,4,18,2,6,34,6,3,1,10,25,16,3,7,9$ (almost never 2, probably because this species does not pair), or 232 Antelope in 26 bands along 70 miles of track; 
but all were on the south side; not one was noted on the north.

The case is simple. During the past winter, while the Antelope were gone southward, the Canadian Pacific Railway Company had fenced its track. In spring the migrants, returning, found themselves cut off from their summer feeding-grounds by those impassable barb-wires, and so were gathered against the barrier. One band of $\delta$, at a stopping place, ran off when they saw passengers alighting, but at half a mile they turned, and again came up against the fence, showing how strong is the northward impulse.

Unless they learn some way of mastering the difficulty, it means extermination for the Antelope of the north Saskatchewan.

From Calgary we went by train to Edmonton. This is the point of leaving the railway, the beginning of hard travel, and here we waited a few days to gather together our various shipments of food and equipment, and to await notice that the river was open.

In the north the grand event of the year is the opening of the rivers. The day when the ice goes out is the official first day of spring, the beginning of the season; and is eagerly looked for, as every day's delay means serious loss to the traders, whose men are idle, but drawing pay as though at work.

On May 11, having learned that the Athabaska was open, we left Edmonton in a livery rig, and drove 94 miles northward though a most promising, half-settled country, and late the next day arrived at Athabaska Landing, on the great east tributary of the Mackenzic, 
whose waters were to bear us onward for so many weeks.

Athabaska Landing is a typical fronticr town. These are hard words, but justified. We put up at the principal hotel; the other lodgers told me it was considered the worst hotel in the world. I thought I knew of two worse, but next morning accepted the prevailing view.

Our canoe and provisions arrived, but the great convoy of scows that were to take the annual supplies of trade stuff for the far north was not ready, and we needed the help and guidance of its men, so must needs wait for four days.

This gave us the opportunity to study the local natural history and do a little collecting, the results of which appear later.

The great size of the timber here impressed me. I measured a typical black poplar ( $P$. balsamifera), 100 feet to the top, $S$ feet 2 inches in circumference, at 18 inches from the ground, and I saw many thicker, but none taller.

At the hotel, also awaiting the scows, was a body of four (dis-)Mounted Police, bound like ourselves for the far north. The officer in charge turned out to be an old friend from Toronto, Major A. M. Jarvis. I also met John Schott, the gigantic half-breed, who went to the Barren Grounds with Caspar Whitney in 1895. He seemed to have great respect for Whitney as a tramper, and talked much of the trip, evidently having forgotten his own shortcomings of the time. While I slietched his portrait, he regaled me with memorjes of 

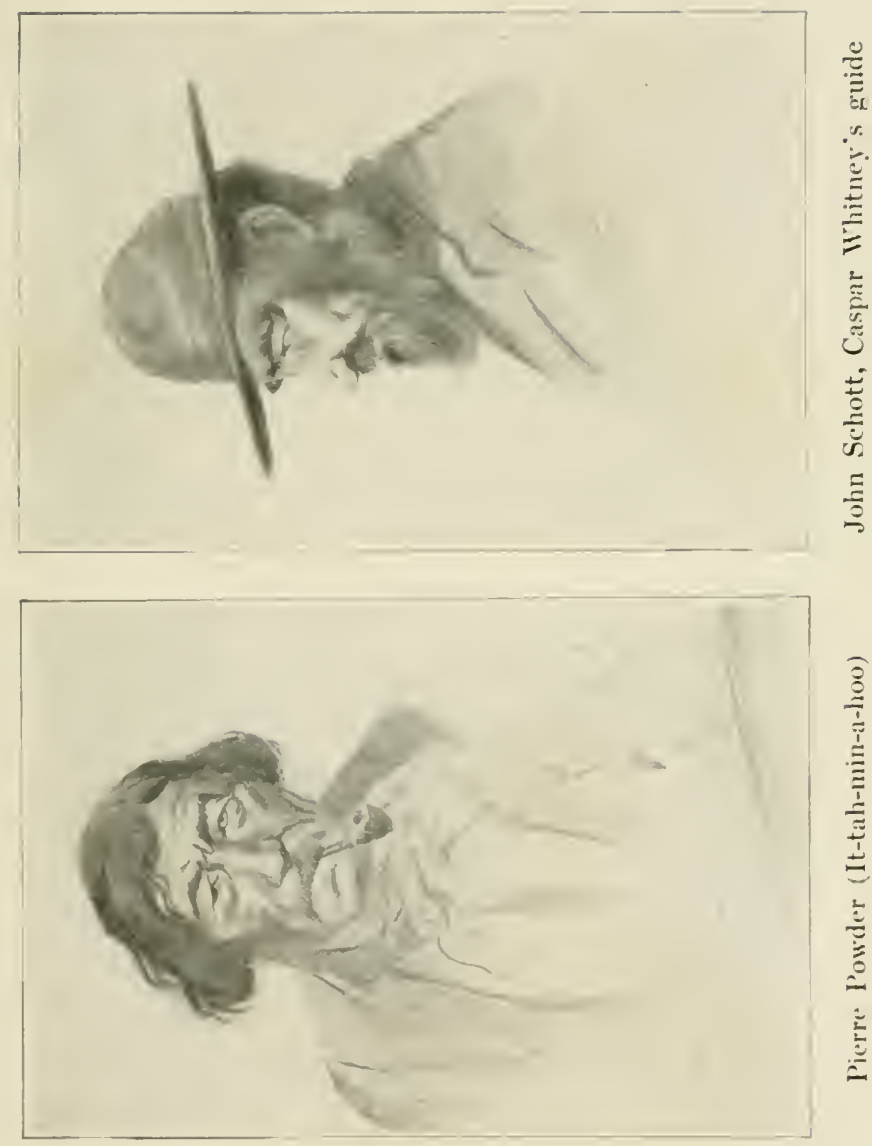

his early days on Red River, where he was bom in 1841 . I did not fail to make what notes I could of those now listoric times. II is accounts of the Antelope on White Horse Plain, in 155.), and Buffalo about the site of Carberry, Manitola, in 1852, were new and valuable light on the ancient ranges of these passing creatures.

All travellers who had preceded me into the Barren Grounds had relied on the abundant game, and in consequence suffered dreadful hardships; in some cases even starved to death. I proposed to rely on no game, but to talie plenty of groceries, the best I could buy in Winnipeg, which means the best in the world; and, as will be seen later, the game, because I was not relying on it, walked into camp every day.

But one canoe could not carry all these provisions, so most of it I shipped on the Hudson's Bay Company scows, taking with ws, in the canoe, food for not more than a week, which with camp outfit was just enough for ballast.

Of course I was in close touch with the Hudson's Bay people. Although nominally that great trading company parted with its autocratic power and exclusive franchise in 1870 , it is still the sovereign of the north. And here let me correct an error that is sometimes found eren in respectable print-the Company has at all times been ready to assist scientists to the utmost of its very ample power. Although jealous of its trading rights, erery one is free to enter the territory without taking count of the Company, but there has not yet been a successful scientific expedition into the region without its active co-operation. 
The Hudson's Bay Company has alway's been the guardian angel of the north.

I suppose that there never yet was another purely commercial concern that so fully realized the moral obligations of its great power, or that has so uniformly done its best for the people it ruled.

At all times it has stood for peace, and one hears over and over again that such and such tribes were deadly enemies, but the Company insisted on their smoking the peace pipe. The Sioux and Ojibway, Black-Foot and Assiniboine, Dog-Rib and CopperKnife, Beaver and Chipewyan, all offer historic illustrations in point, and many others could be found for the list.

The name Peace River itself is the monument of a successful effort on the part of the Company to bring about a better understanding between the Crees and the Beavers.

Besides human foes, the Company has saved the Indian from famine and plague. Many a hungerstricken tribe owes its continued existence to the fatherly care of the Company, not simply general and indiscriminate, but minute and personal, carried into the details of their lives. For instance, when bots so pestered the Caribou of one region as to render their hides useless to the natives, the Company brought in hides from a district where they still were good.

The Chipewyans were each spring the victims of snow-blindness until the Company brought and succeeded in popularizing their present ugly but effectual and universal peaked hats. When their train-dogs 
were rumning down in physique, the Company brought in a strain of pure Huskies or Eskimo. When the Albany River Indians were starving and unable to hunt, the Company gare the order for 5,000 lodge poles. Then, not knowing how else to turn them to account, commissioned the Indians to work them into a picket garden-fence. At all times the native found a father in the Company, and it was the worst thing that ever happened the region when the irresponsible free-traders with their demoralizing methods were allowed to enter and traffic where or how they pleased.

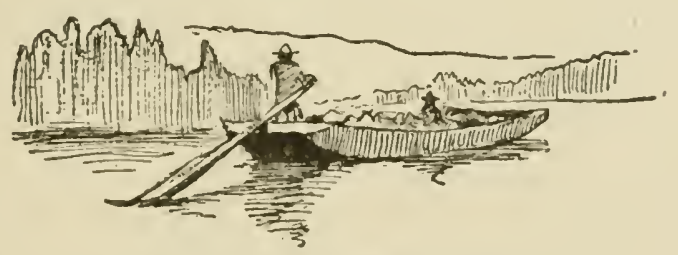

Indian Pilot. May 19, 1907 


\section{CHAPTER II}

\section{DOWN THE NOISY RIVER WITH THE VOYAGEURS}

Aт Athabaska Landing, on May 1S, 1907, 10.15 A. M., we boarded the superb Peterborough canoe that I had christened the Ann Seton. The Athabaska River was a-flood and clear of ice; 13 scows of freight, with 60 half-breeds and Indians to man them, left at the same time, and in spite of a strong headwind we drifted northward fully $3 \frac{1}{2}$ miles an hour.

The leading scow, where I spent some time, was in charge of John MacDonald himself, and his passengers comprised the Hudson's Bay Company officials, going to their posts or on tours of inspection. They were a jolly crowd, like a lot of rollicking schoolboys, full of fun and good-humour, chaffing and joking all day; but when a question of business came up, the serious business man appeared in each, and the Company's interest was cared for with their best powers. The bottle was not entirely absent in these scow fraternities, but I saw no one the worse for liquor on the trip.

The men of mixed blood jabbered in French, Cree, and Chipewyan chiefly, but when they wanted tc swear, they felt the inadequacy of these mellifuous or lisping tongues, and fell back on virile Saxon, whose tang, projectivity, and wealth of vile epithet evidently supplied a long-felt want in the Great Lone Land of the Dog and Canoe. 


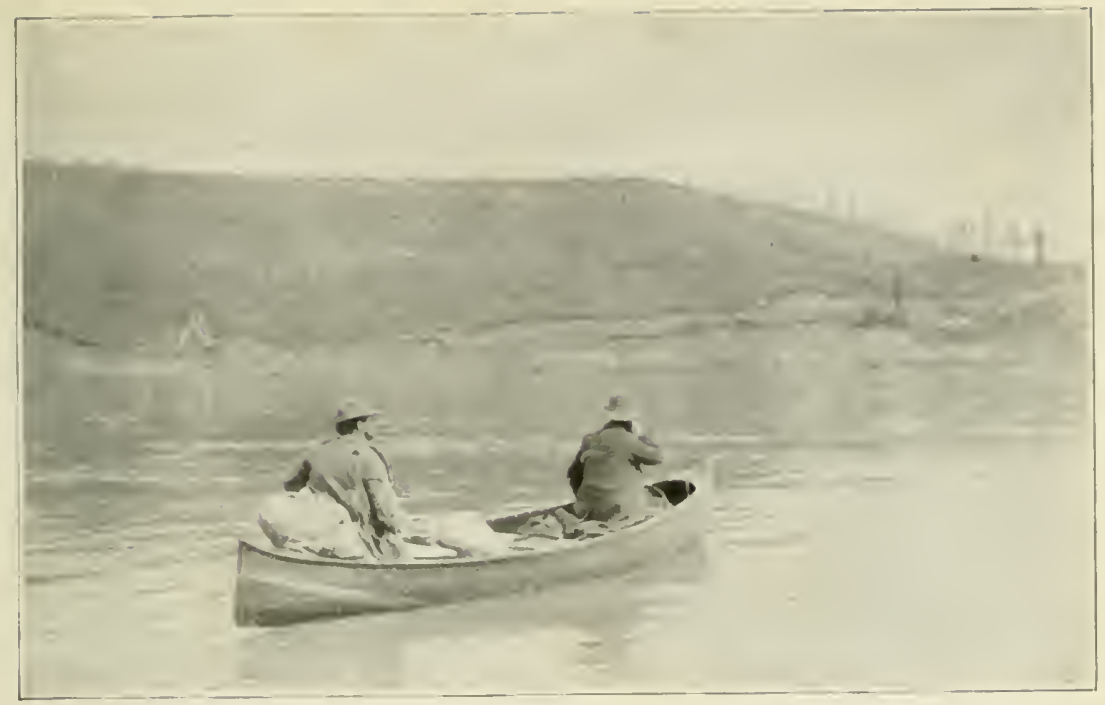

E. T. Seton and E. $\Lambda$. Preble leaving $\Lambda$ thabaska Landing, May 17, 1907

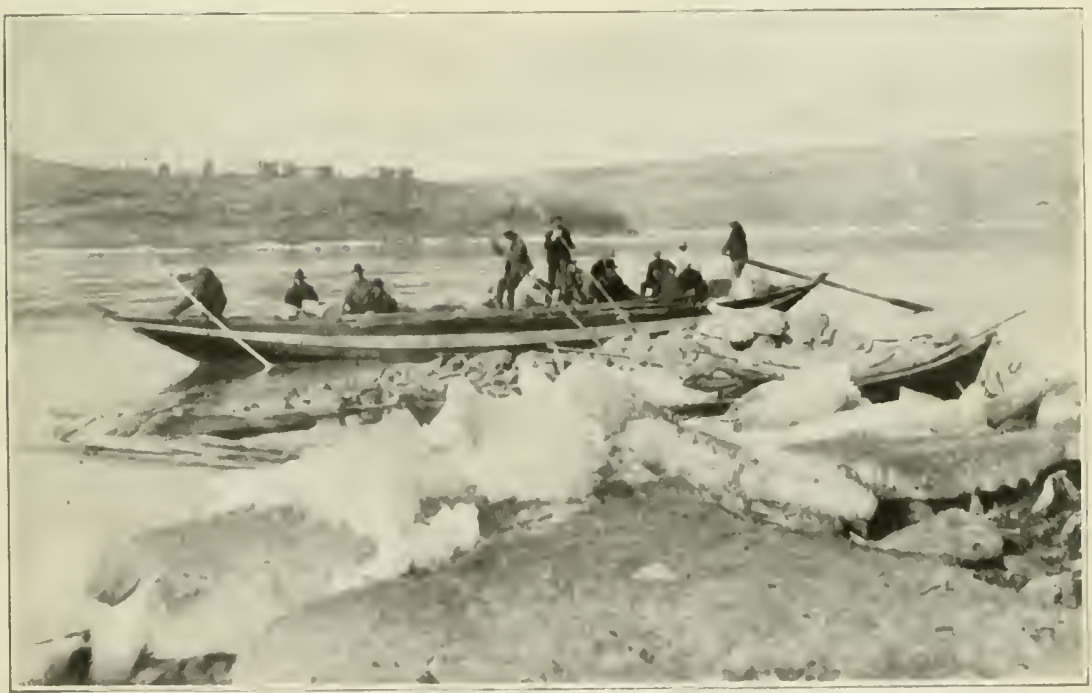

Down the Athabaska River 

In the afternoon Preble and I pushed on in our boat, far in advance of the brigade. As we made early supper I received for the twentieth time a lesson in photography. A cock Partridge or Ruffed Grouse came and drummed on a log in open view, full sunlight, fifty feet away. I went quietly to the place. He walked off, but little alarmed. I set the camera eight feet from the log, with twenty-five feet of tubing, and retired to a good hiding-place. But alas! I put the tube on the left-hand pump, not knowing that that was a dummy. The Grouse came back in three minutes, drumming in a superb pose squarely in front of the camera. I used the pump, but saw that it failed to operate; on going forward the Grouse skimmed away and returned no more. Preble said, "Never" mind; there will be another every hundred yards all the way down the river, later on." I could only reply, "The chance never comes but once," and so it proved. We heard Grouse drumming many times afterward, but the sun was low, or the places densely shaded, or the mosquitoes made conditions impossible for silent watching; the perfect chance came but once, as it always does, and I lost it.

About twenty miles below the Landing we found the abandoned winter hut of a trapper; on the roof were the dried up bodies of 1 Skunk, 2 Foxes, and 30 Lynxes, besides the bones of 2 Moose, showing the nature of the wild life about.

That night, as the river was brimming and safe, we tied up to the scows and drifted, making 30 more miles, or 60 since embarking. 
In the early morning, I was much struck by the lifelessness of the scene. The great river stretched away northward, the hills rose abruptly from the water's edge, everywhere extended the superb spruce forest, here fortunately unburnt; but there seemed no sign of iiving creature outside of our own numerous, noisy,

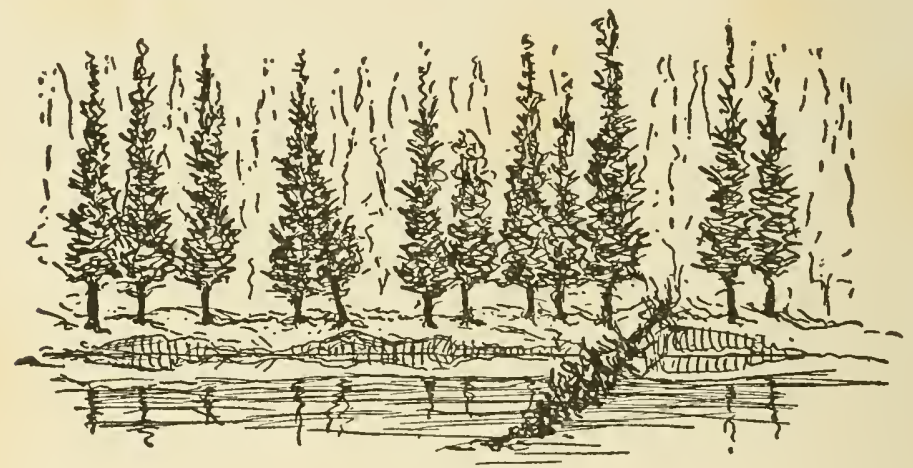

The Roll Call

and picturesque party. River, hills, and woods were calm and silent. It was impressive, if disappointing; and, when at last the fir stillness was broken by a succession of trumpet notes from the Great Pileated Woodpecker, the sound went rolling on and on, in reverberating echoes that might well have alarmed the bird himself.

The white spruce forest along the banks is most inspiring; magnificent here. Down the terraced slopes and right to the water's edge on the alluvial soil it stands in ranks. Each year, of course, the floods undercut the banks, and more trees fall, to become at last the flotsam of the shore a thousand miles away. 


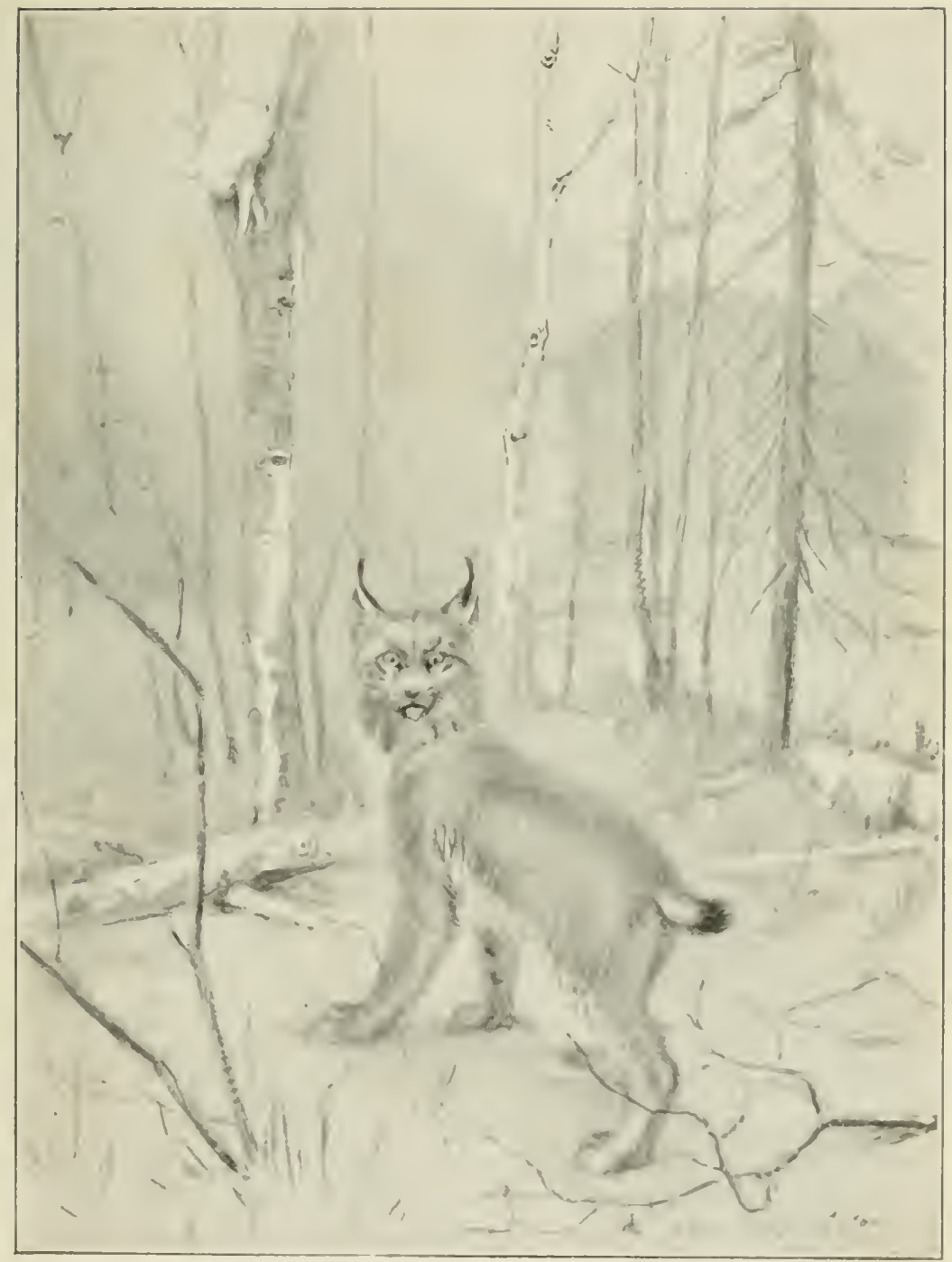

I found it was a dead house-cat; . . . under it was a loungry-looking Iyux 

There is something sad about these stately trees, densely packed, all a-row, unflinching, hopelessly awaiting the onset of the incxorable, invincible river. One group, somewhat isolated and formal, was a forest life parallel to Lady Butler's famous "Roll Call of the Grenadiers."

At night we reached the Indian village of Pelican Portage, and landed by climbing orer huge blocks of ice that were piled along the shore. The adult male inhabitants came down to our camp, so that the village was deserted, except for the children and a few women.

As I walked down the crooked trail along which straggle the eabins, I saw something white in a tree at the far cnd. Supposing it to be a White-rabbit in a snare, I went near and found, to my surprise, first that it was a dead house-cat, a rare species here; second, under it, eyeing it and me alternately, was a hungrylooking Lynx. I had a camera, for it was near sundown, and in the woods, so I went back to the boat and returned with a gun. There was the Lynx still prowling, but now farther from the village. I do not believe he would have harmed the children, but a Lynx is game. I fired, and he fell without a quiver or a sound. This was the first time I had used a gun in many years, and was the only time on the trip. I felt rather guilty, but the carcass was a godsend to two old Indians who were sickening on a long diet of salt pork, and that Lynx furnished them tender meat for three days afterward; while its skin and skull went to the American Museum. 
On the night of May 20, we camped just above Grand Rapids-Preble and I alone, for the first time, under canvas, and glad indecd to get away from the noisy rabble of the boatmen, though now they were but a quarter mile off. At first I had found them amusing and picturesque, but their many unpleasant habits, their distinct aversion to strangers, their greediness to get all they could out of one, and do nothing in return, combined finally with their habit of gambling all night to the loud beating of a tin pan, made me thankful to quit their company for a time.

At Grand Rapids the scows were unloaded, the goods shipped over a quarter-mile hand tramway, on an island, the scows taken down a side channel, one by one, and reloaded. This meant a delay of three or four days, during which we camped on the island and gathered specimens.

Being the organizer, equipper, geographer, artist, head, and tail of the expedition, I was, perforce, also its doctor. Equipped with a "pill-kit," an abundance of blisters and bandages and some "potent purgatives," I had prepared myself to render first and last aid to the hurt in my own party. In taking instructions from our family physician, I had learned the value of a profound air of great gravity, a noble reticence, and a total absence of doubt, when I did speak. I compressed his creed into a single phrase: "In case of doubt, look wise and work on his 'bowels." "This simple equipment soon gave me a surprisingly high standing among the men. I was a medicine man of replice, and soon had a larger practice than I desired, as it was entirely gratuitous. 


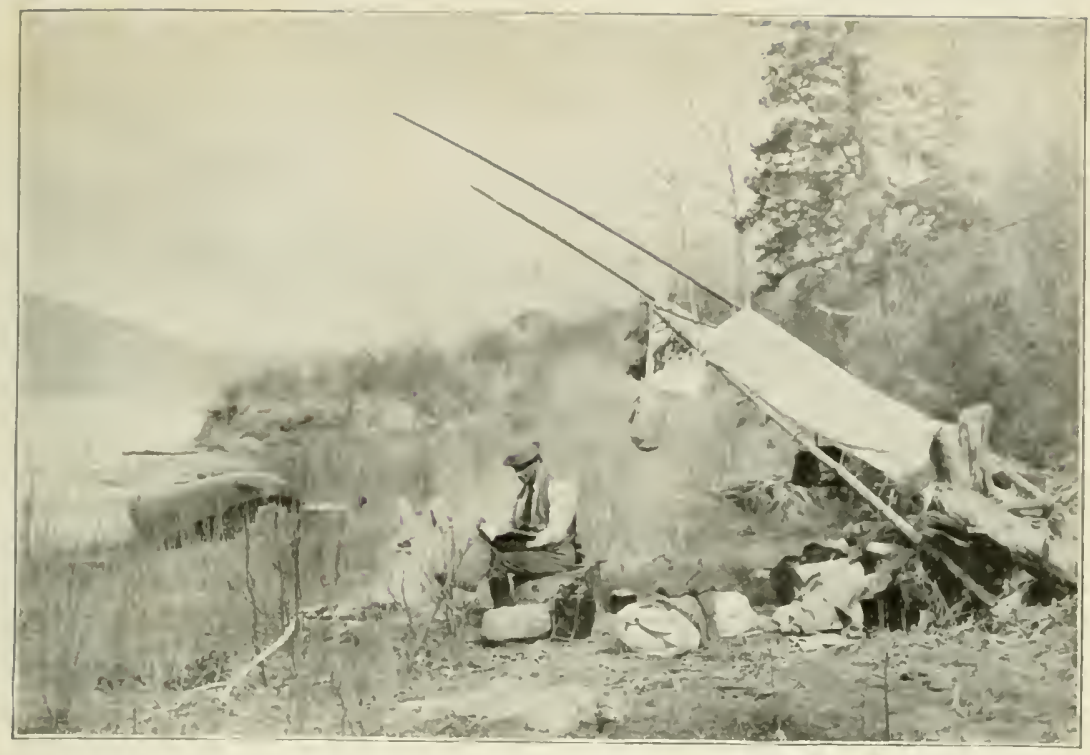

Our camp above Grand Rapids, Athabaska River

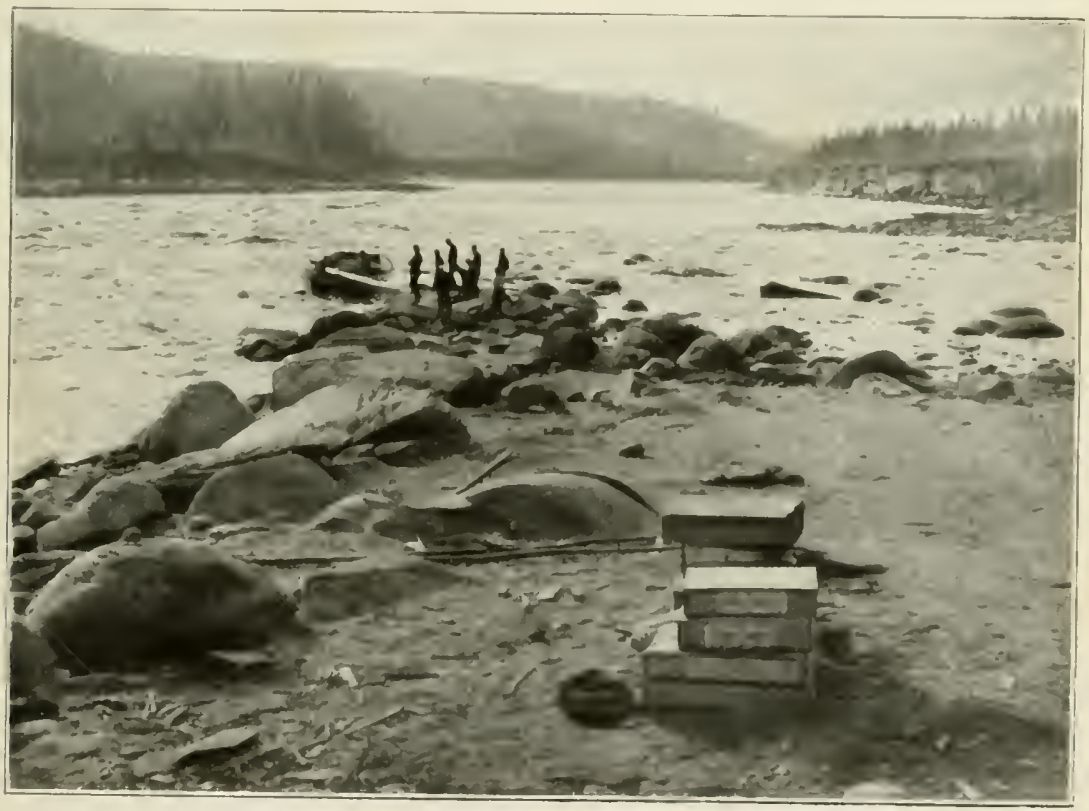

Looking down the Athabaska River from the island in the Grand lapids 

The various boatmen, Indians and half-breeds, came with their troubles, and, thanks chiefly to their faith, were cured. But one day John MacDonald, the ehief pilot and a mighty man on the river, came to my tent (on Grand Islind. John complained that he couldn't hold anything on his stomach; he was a total peristaltic wreck indeed (my words; his were more simple and more vivid, but less sonorous and professional). He sald he had been going down hill for two weeks, and was so bad now that he was "no better than a couple of ordinary men."

"Exactly so," I said. "Now you take these pills and you'll be all right in the morning." Next morning John was back, and eomplained that my pills had no effect: he wanted to foel something take hold of him. Hadn't I any pepuer-juice or brandy?

I do not take liquor on an expedition, but at the last moment a Wimnipeg friend had given me a pint flask of pure brandy-"for cmergencies." An emergeney had come.

"John! you shall have some extra fine brandy, nicely thinned with pepper-juice." I poured half an inch of brandy into a tin eup, then added half an inch of "pain-killer."

"Here, take this, and if you don't feel it, it means your insides are dead, and you may as well order your coffin."

John took it at a gulp. His insides were not dead; but I might have been, had I been one of his boatmen.

IIc doubled up, rolled around, and danced for five minutes. He did not squeal-John never squeals-but 
he suffered some, and an hour later announced that he was about cured.

Next day he came to say he was all right, and would soon again be as good as half a dozen men.

At this same camp in Grand Rapids another cure on a much larger scale was added to my list. An Indian had "the bones of his foot broken," crushed by a heavy weight, and was badly crippled. He came leaning on a friend's shoulder. His foot was blackened and much swollen, but I soon satisfied myself that no bones were broken, because he could wriggle all the toes and move the foot in any direction.

"You'll be better in three clays and all right in a week," I said, with calm assurance. Then I began with massage. It seemed necessary in the Indian environment to hum some tune, and I found that the "Koochy-Koochy" lent itself best to the motion, so it became my medicine song.

With many "Koochy-Koochy"-ings and much icecold water he was nearly cured in three days, and sound again in a week. But in the north folk have a habit (not known elsewhere) of improving the incident. Very soon it was known all along the river that the Indian's leg was broken, and I had set and healed it in three days. In a year or two, I doubt not, it will be his neck that was broken, not once, but in several places.

Grand Island yielded a great many Deermice of the arcticus form, a few Red-backed Voles, and any number of small birds migrant.

As we floated down the river the eye was continu- 
ally held by tall and prominent spruce trees that had been cut into peculiar forms as below. These were known as "lob-sticks," or "lop-sticks," and are usually the monuments of some distinguished visitor in the country or records of some heroic achievement. Thus, one would be pointed out as Commissioner Wrigley's lob-stick, another as John MacDonald's the time he saved the scow.

The inauguration of a lob-stick is quite a ceremony. Some person in camp has impressed all with his importance or other claim to notice. The men, having talked it over, announce that they have decided on giving him a lob-stick. "Will he make choice of some prominent tree in

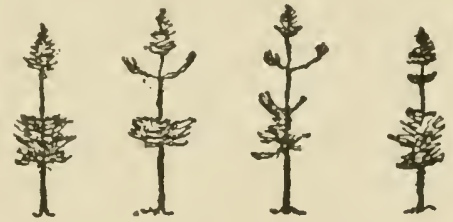

Lob-sticks, or trees trimmed as monuments, along the river

view?" The visitor usually selects one back from the water's edge, often on some far hilltop, the more prominent the better; then an active young fellow is sent up with an axe to trim the tree. The more embellishment the higher the honor. On the trunk they then inseribe the name of the stranger, and he is supposed to give each of the men a plug of tobacco and a drink of whiskey. Thus they celebrate the man and his monument, and ever afterwards it is pointed out as "So-and-so's lob-stick."

It was two months before my men judged that I was entitled to a lob-stick. We were then on Great Slave Lake where the timber was small, but the best they could get on a small island was chosen and trimmed 
into a monument. They were disappointed however, to find that I would by no means give whiskey to natives, and my treat had to take a wholly different form.

Grand Rapids, with its multiplicity of perfectly round pot-hole boulders, was passed in four days, and then, again in company with the boats, we entered the real canyon of the river.

Down Athabaska's hoiling flood

Of seething, leaping, coiling mud. 


\section{CHAPTER III}

\section{HUMAN NATURE ON TIE RIVER}

Sundar moming, 26th of Nay, there was something like a strike among the sixty half-breeds and Indians that composed the crews. They were strict Sabbatarians (when it suited them); they believed that they should do no work, but give up the day to gambling and drinking. Old John, the chief pilot, wished to take adrantage of the fine flood on the changing river, and drift down at least to the head of the Boiler Rapids, twenty miles away. The breeds maintained, with many white swear words, for lack of strong talk in Indian, that they never yet knew Sunday work to end in anything but disaster, and they sullenly scattered among the trees, produced their cards, and proceeded to gamble away their property, next year's pay, clothes, families, anything, and otherwise show their respect for the Lord's Day and defiance of old John MacDonald. John made no reply to their arguments; he merely boarded the cook's boat, and pushed off into the swift stream with the cooks and all the grub. In five minutes the strikers were on the twelve big boats doing thcir best to live up to orders. John said nothing, and grinned at me only with his eyes.

The breeds took their defeat in good part after the first minute, and their commander rose higher in their respect. 
At noon we camped above the Boiler Rapids. In the evening I climbed the 400- or 500-foot hill behind camp and sketched the canyon looking northward. The spring birds were now beginning to arrive, but

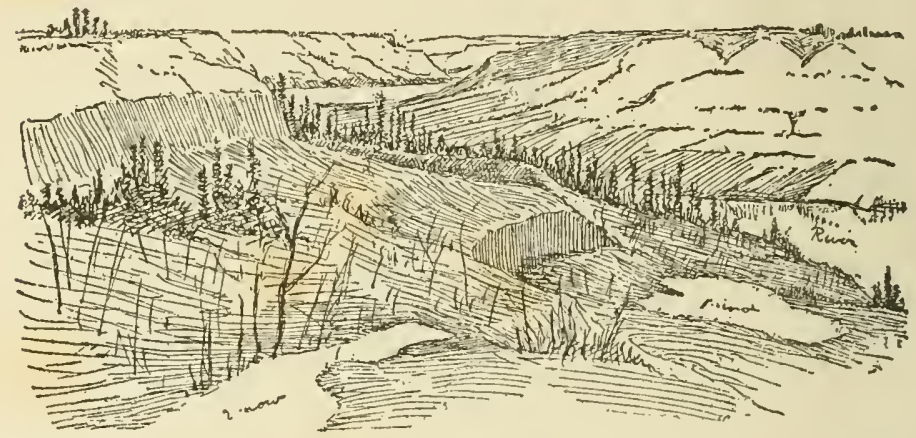

Canyon of the Athabaska River, looking north

were said to be a month late this year. The ground was everywhere marked with moose sign; prospects were brightening.

The mania for killing that is seen in many white men is evidently a relic of savagery, for all of these Indians and half-breeds are full of it. Each carries a rifle, and every living thing that appears on the banks or on the water is fusilladed with Winchesters until it is dead or out of sight. This explains why we see so little from the scows. One should be at least a day ahead of them to meet with wild life on the river.

This morning two Bears appeared on the high bank -and there was the usual uproar and fusillading; so far as could be learned without any effect, except the expenditure of thirty or forty cartridges at five cents each. 


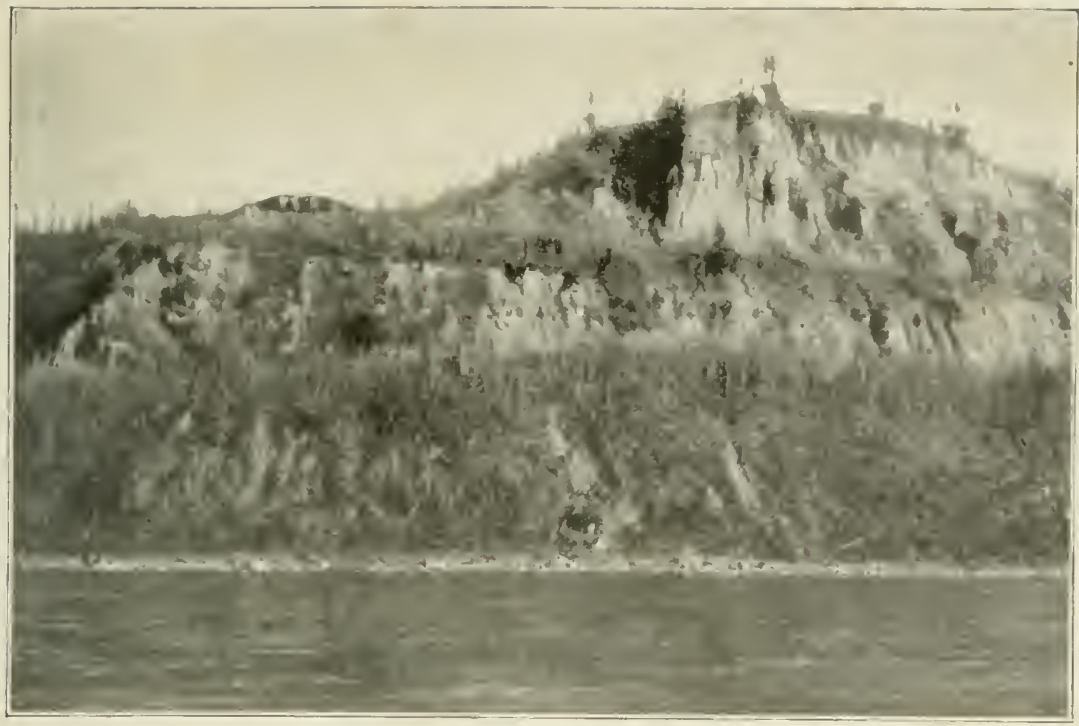

Lobsticks or Monument Trees on the skyline, Athabaska Rivei

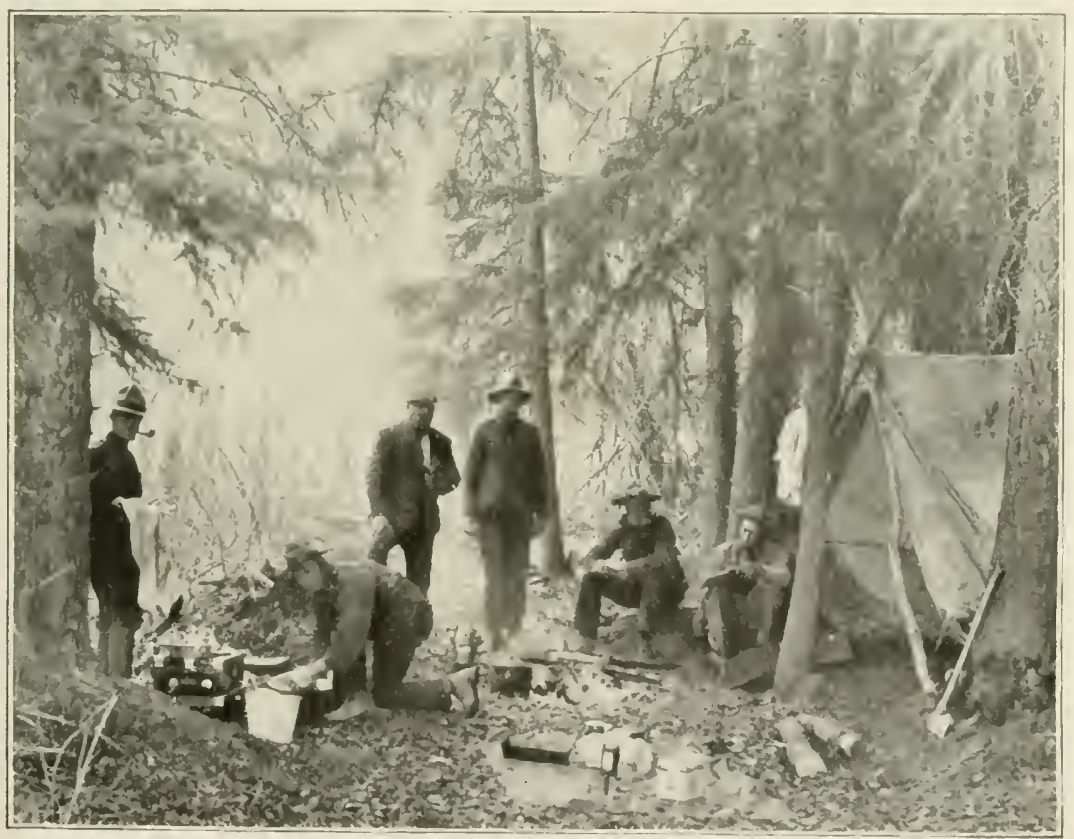

Camp on the Great Slave River 

On the 27th we came to the Cascade Rapids. The first or Little Cascade has about two feet fall, the second or Grand Cascade, a mile farther, is about a six foot sheer drop. These are considered very difficult

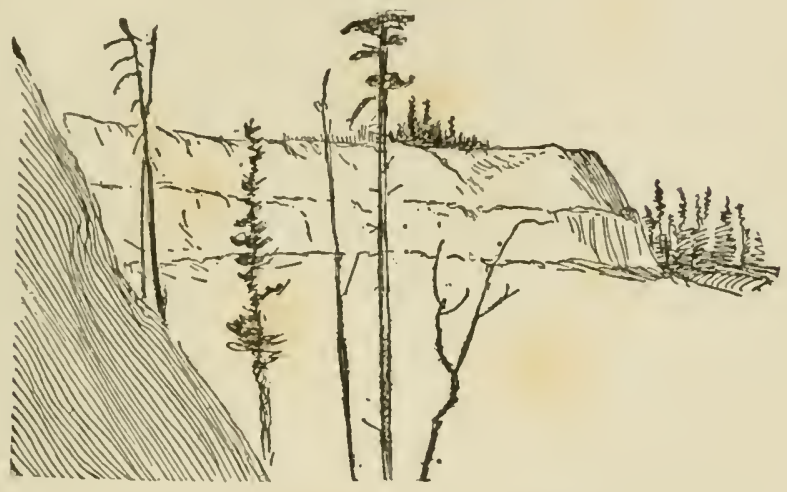

Natural amphitheatre on Athabaska Canyon

to run, and the manner of doing it changes with every change in season or water level.

We therefore went through an important ceremony, always carried out in the same way. All 13 boats were beached, the 13 pilots went ahead on the bank to study the problem, they decided on the one safe place and manner, then returned, and each of the 13 boats was run over in 13 different places and manners. They always do this. You are supposed to have run the Cascades successfully if you cross them alive, but to have failed if you drown. In this case all were successful.

Below the Cascades I had a sample of Indian gratitude that set me thinking. $\mathrm{My}$ success with John 
MacDonald and others had added the whole community to my medical practice, for those who were not sick thought they were. I cheerfully did my best for all, and was supposed to be persona grata. Just below the Cascade Rapids was a famous sucker pool, and after we had camped three Indians came, saying that the pool was full of suckers---would I lend them my canoe to get some?

Away they went, and from afar I was horrified to see them clubbing the fish with my beautiful thinbladed maple paddles. They returned with a boat load of 3- and 4-pound Suckers (Catostomus) and 2 paddles broken. Each of their friends came and received one or two fine fish, for there were plenty. I, presumably part owner of the catch, since I owned the boat, selected one small one for myself, whereupon the Indian insolently demanded 25 cents for it; and these were the men I had been freely doctoring for two weeks! Not to speak of the loaned canoe and broken paddles! Then did I say a few things to all and sundry - stinging, biting things, ungainsayable and forcible things-and took possession of all the fish that were left, so the Indians slunk off in sullen silence.

Gratitude seems an unknown feeling among these folk; you may give presents and help and feed them all you like, the moment you want a slight favour of them they demand the uttermost cent. In attempting to analyse this I was confronted by the fact that among themselves they are kind and hospitable, and at length discovered that their attitude toward us is founded on the ideas that all white men are very rich, 
that the Indian has made them so by allowing them to come into this country, that the Indian is very poor because he never was properly compensated, and that therefore all he can get out of said white man is much less than the white man owes him.

As we rounded a point one day a Lynx appeared statnesque on a stranded cake of ice, a hundred yards off, and gazed at the approaching boats. True to their religion, the half-breeds seized their rifles, the bullets whistled harmlessly about the "Peeshoo"-whereupon he turned and walked calmly up the slope, stopping to look at each fresh volley, but finally waved his stumpy tail and walked unharmed over the ridge. Distance fifty yards.

On May 28 we reached Fort MacMurray.

Here I saw several interesting persons: Miss Christine Gordon, the postmaster; Joe Bird, a half-breed with all the advaneed ideas of a progressive white man; and an American ex-patriot, G-, a tall, raw-boned Yank from Illinois. He was a typical Ameriean of the kind that knows little of America and nothing of Europe; but shrewd and successful in spite of these limitations. In appearance he was not unlike Abraham Lincoln. He was a rabid American, and why he stayed here was a question.

He had had no detailed tidings from home for years, and I never saw a man more keen for the news. On the banks of the river we sat for an hour while he plied me with questions, which I answered so far as I could. He hung on my lips; he interrupted only when there seemed a halt in the stream; he revelled in all the de- 
tails of wrecks by rail and sea. Roosevelt and the trusts-insurance scandals-the lynchings in the South -the burnings in the West-massacres-murdershorrors-risings-these were his special gloats, and yet he kept me going with "Yes-yes-and then?" or "Yes, by golly-that's the way we're a-doing it. Go on."

Then, after I had robbed New York of $\$ 100,000,000$ a year, burnt 10 large towns and 45 small ones, wrecked 200 express trains, lynched 96 negroes in the Southand murdered many men every night for 7 years in Chicago-he broke out:

"By golly, we are a-doing it. We are the people. We are a-moving things now; and I tell you I give the worst of them there European countries, the very worst of 'em, just 100 years to become Americanised."

Think of that, ye polished Frenchmen; ye refined, courteous Swedes; ye civilised Danes; you have 100 years to become truly Americanised!

All down the river route we came on relics of another class of wanderers-the Klondikers of 1898. Sometimes these were empty winter cabins; sometimes curious tools left at Hudson's Bay Posts, and in some cases expensive provisions; in all cases we heard weird tales of their madness.

There is, I am told, a shanty on the Mackenzie above Simpson, where four of them made a strange record. Cooped up for months in tight winter quarters, they soon quarrelled, and at length their partnership was dissolved. Each took the articles he had contributed, and those of common purchase they divided in four 

equal parts. The stove, the canoe, the lamp, the spade, were broken relentlessly and savagely into four parts-four piles of useless rubbish. The shanty was divided in four. One man had some candles of his own bringing. These he kept and earefully screened off his corner of the room so no chance rays might reach the others to comfort them; they spent the winter in darkness. None spoke to the other, and they parted, singly and silently, hatcfully as ever, as soon as the springtime opened the way. 


\section{CHAPTER IV}

\section{DOWN THE SILENT RIVER IVITII THE MOUNTED POLICE}

At Fort MacMurray we learned that there was no telling when the steamer might arrive; Major Jarvis was under orders to proceed without delay to Smith Landing; so to solve all our difficulties I bought a 30 -foot boat (sturgeon-head) of Joe Bird, and arranged to join forces with the police for the next part of the journey.

I had made several unsuccessful attempts to get an experienced native boatman to go northward with me. All seemed to fear the intending plunge into the unknown; so was agreeably surprised when a sturdy young fellow of Scottish and Cree parentage came and volunteered for the trip. A few inquirics proved him to bear a good reputation as a river-man and worker, so William C. Loutit was added to my expedition and served me faithfully throughout.

In time I learned that Billy was a famous traveller. Some years ago, when the flood had severed all communication between Athabaska Landing and Edmonton, Billy volunteered to carry some important despatches, and covered the 96 miles on foot in one and a half days, although much of the road was under water. On another occasion he went alone and afoot from House River up the Athabaska to Calling River, and 
across the Point to the Athabaskit again, then up to the Landing-150 rough miles in four days. These cxploits I had to find out for myself later on, but much more important to me at the time was the fact that he was a first-class cook, a steady, checrful worker, and a capable guide as far as Great Slave Lake.

The Athabaska below Fort MacMurray is a noble stream, one-third of a mile wide, deep, steady, un-

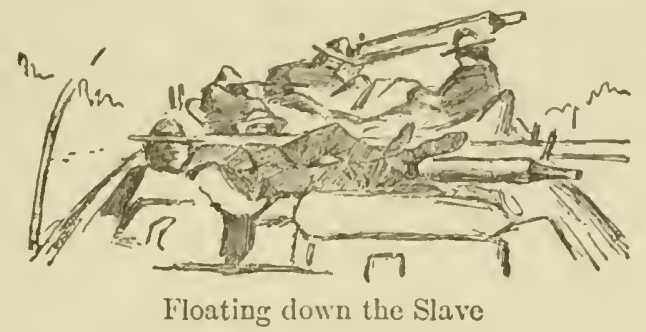

marred; the banks are covered with unbroken virginal forests of tall white poplar, balsam poplar, spruce, and birch. The fire has done no damage here as yet, the axe has left no trace, there are no houses, no sign of man except occasional teepec poles. I could fancy myself floating down the Ohio two hundred years ago.

These were bright days to be remembered, as we drifted down its placid tide in our ample and comfortable boat, with abundance of good things. Calm, lorely, spring weather; ducks all along the river; plenty of food, which is the northerner's idea of bliss; plenty of water, which is the river-man's notion of joy; plenty of leisure, which is an element in most men's heaven, for we had merely to float with the stream, three miles an hour, except when we landed to eat or sleep. 
The woods were donning their vernal green and resounded with the calls of birds now. The mosquito plague of the region had not yet appeared, and there was little lacking to crown with a halo the memory of those days on the Missouri of the North.

Native quadrupeds seemed scarce, and we were all agog when one of the men saw a black fox trotting along the opposite bank. However, it turned out to

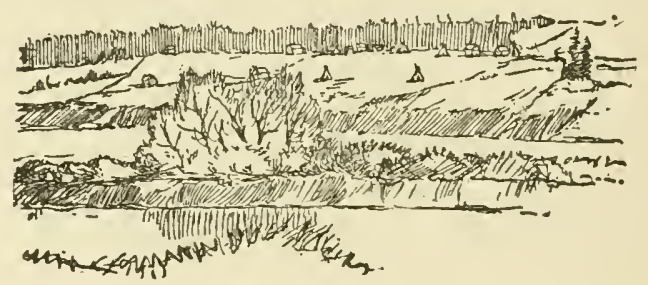

Fort McIKay

be one of the many stray dogs of the country. He followed us a mile or more, stopping at times to leap at fish that showed near the shore. When we landed for lunch he swam the broad stream and hung about at a distance. As this was twenty miles from any settlement, he was doubtless hungry, so I left a bountiful lunch for him, and when we moved away, he claimed his own.

At Fort McKay I saw a little half-breed boy shooting with a bow and displaying extraordinary marksmanship. At sixty feet he could hit the bottom of a tomato tin nearly every time; and even more surprising was the fact that he held the arrow with what is known as the Mediterranean hold. When, months later, I again stopped at this place, I saw another boy 
doing the very same. Some residents assured me that this was the style of all the Chipewyans as well as the Crees.

That night we eamped far down the river and on the side opposite the Fort, for experienee soon teaches one to give the dlogs no chance of entering camp on marauding expeclitions while you rest. About ten, as I was going to sleep, Preble put his head in and said: "Cone out here if you want a new sensation."

In a moment I was standing with him under the tall spruce trees, looking over the river to the dark forest, a quarter mile away, and listening intently to a new and wonderful sound. Like the slow tolling of a soft but high-pitched bell, it came. T'ing, ting, ting, ting, and on, rising and falling with the breeze, but still keeping on about two "tings" to the second, and on, dulling as with distance, but rising again and again.

It was unlike anything I had ever heard, but Preble knew it of old. "That," says he, "is the love-song of the Richardson Owl. She is sitting demurely in some spruce top while he sails around, singing on the wing, and when the sound secms distant, he is on the far side of the tree."

Ting, ting, ting, ting, it went on and on, this soft belling of his love, this amorous music of our northern bell-bird.

Ting, TING, ting, ting, ting, TING, ting, ting, ting, ting, TING, ting-oh, how could any lady owl resist such strains?-and on, with its ting, ting, ting, TING, ting, ting, ting, TING, the whole night ail was vibrant. Then, as though by plan, a different note-the deep boom- 
ing "Oho-oh-who-oh who hoo" of the Great Horned Owl-was heard singing a most appropriate bass.

But the little Owl went on and on; 5 minutes, 10 minutes, 20 minutes at last had elapsed before I turned in again and left him. More than once that night I awoke to hear his "tinging" serenade upon the consecrated air of the pincy woods.

Yet Preble said this one was an indifferent performer. On the Mackenzie he had heard far better singers of

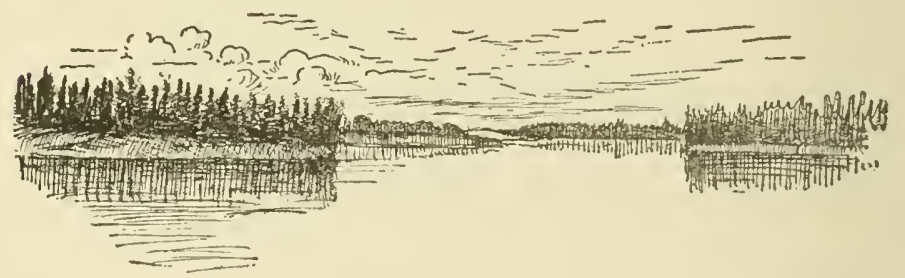

Athabaska River looking north from Poplar Point

the kind; some that introduce many variations of the pitch and modulation. I thought it one of the most charming bird voices I had ever listencel to-and felt that this was one of the things that make the journey worth while.

On June 1 the weather was so blustering and wet that we did not break camp. I put in the day examining the superb timber of this bottom-land. White spruce is the prevailing conifer and is here seen in perfection. A representative specimen was 118 feet high, 11 feet 2 inches in circumference, or 3 feet $6 \frac{1}{2}$ inches in diameter 1 foot from the ground, $i . e$, above any root spread. There was plenty of timber of similar height. Black spruce, a smaller kind, and tamarack 


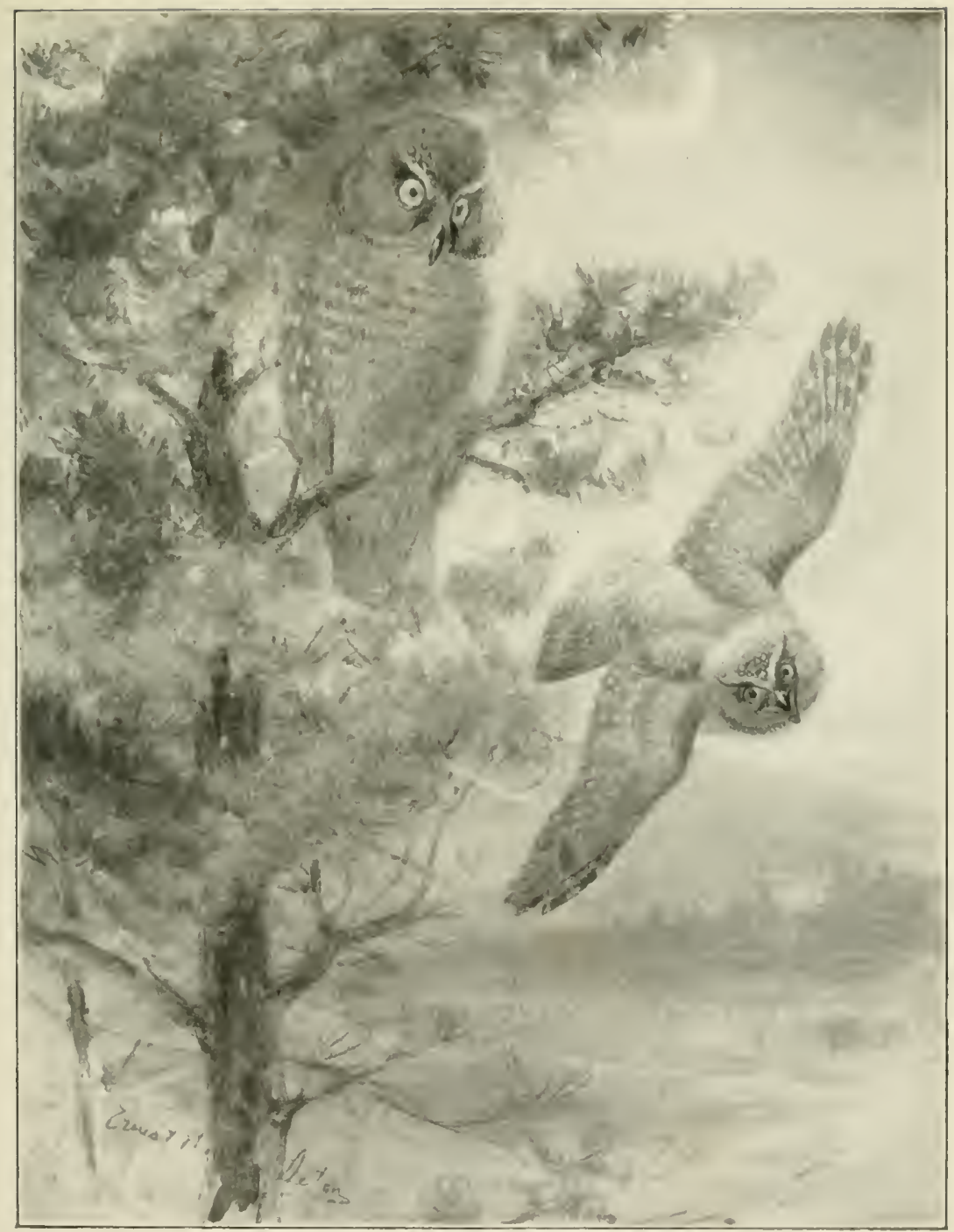

The love-songr of the Richardson Owl 

are found farther up and back in the bog country. jackpine of fair sizc aloounds on the sandy and gravelly parts. Balsam poplar is the largest deciduous tree; its superb legions in upright ranks are crowded along all the river banks and on the islands not oecupied by the spruce. The large trees of this kind often have deep holes; these are the nesting sites of the Whistler Duck, which is found in numbers here and as far north as this tree, but not farther. White poplar is plentiful

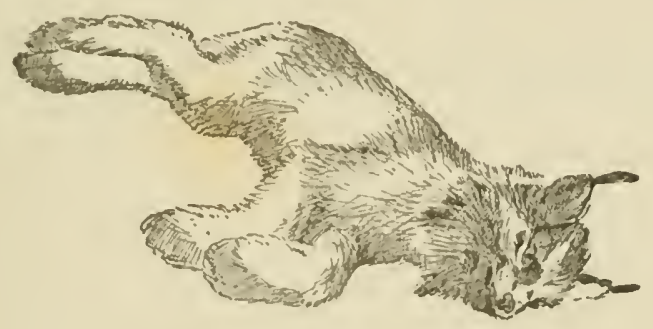

Male Lynx. June 3, 1907

also; the hillsides are beautifully clad with its purplish masses of twigs, through which its white stems gleam like marble columns. White birch is common and large enough for canoes. Two or three species of willow in impenetrable thickets make up the rest of the forest stretelies.

At this camp I had the unique experience of showing all these seasoned Westerners that it was possible to mike a fire by the friction of two sticks. This has long been a specialty of mine; I use a thong and a bow as the simplest way. Ordinarily I prefer balsam-fir or tamarack; in this ense I used a balsam block and a spruce drill, and, although each kind failed when used 
with drill and block the same, I got the fire in half a minute.

On June 3 we left this camp of tall timber. As we floated down we sighted a Lynx on the bank looking contemplatively into the flood. One of the police boys seized a gun and with a charge of No. 6 killed the Lynx. Poor thing, it was in a starving condition, as indeed are most meat-eaters this year in the north. Though it was fully grown, it weighed but 15 pounds.

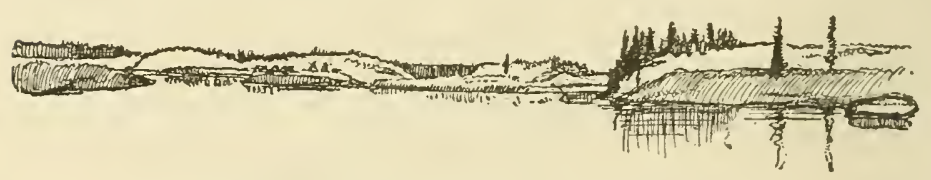

Poplar Point, Athabaska River, from north

In its stomach was part of a sparrow (white-throat?) and a piece of rawhide an inch wide and 4 feet long, evidently a portion of a dog-harness picked up somewhere along the river. I wonder what he did with the bells.

That night we decided to drift, leaving one man on guard. Next day, as we neared Lake Athabaska, the shores got lower, and the spruce disappeared, giving way to dense thickets of low willow. Here the long expected steamer, Graham, passed, going upstream. We now began to get occasional glimpses of Lake Athabaska across uncertain marshes and sand bars. It was very necessary to make Fort Chipewyan while there was a calm, so we pushed on. After four hours' groping among blind channels and mud banks, we reached the lake at midnight-though of course there 
was no night, but a sort of gloaming even at the clarkest-and it took us four hours' hard rowing to cover the ten miles that separated us from Chipewyan.

It sounds very easy and commonplace when one says "hard rowing," but it takes on more significance when one is reminded

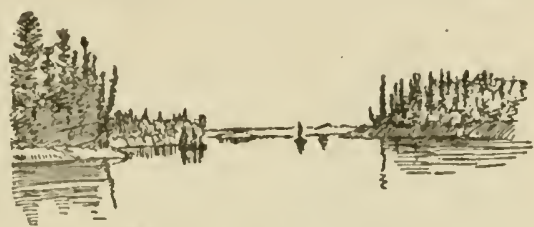

Mouth of Peace River that those oars were 18 feet long, 5 inches through, and weighed about 20 pounds each; the boat was 30 feet long, a demasted schooner indeed, and rowing her through shallow muddy water, where the ground suction was excessive, macle labour so heavy that 15minute spells were all any one could do. We formed four relays, and all worked in turn all night through, arriving at Chipewyan 4 A. x., blistered, sore, and completely tired out.

Fort Chipewyan (pronounced Chip-we-yań) was Billy Loutit's home, and here we met his father, mother, and numerous as well as interesting sisters. Mean-

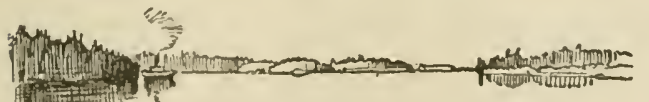

Slave River. June 6, 1907 while I called at the Roman Catholic Mission, under Bishop Gruard, and the rival establishment, under Reverend Roberts, good men all, and devoted to the cause, but loving not each other. The Hudson's Bay Company, however, was here, as everywhere in the north, the really important thing.

There was a long stretch of clead water before we 
could resume our downward drift, and, worse than that, there was such a flood on the Peace River that it was backing the Athabaska, that is, the tide of the latter was

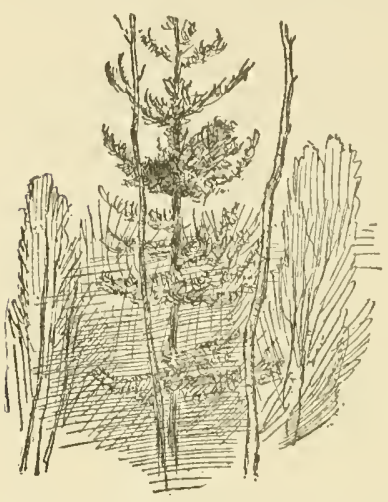

Crow's Nest, Fort Smith Landing reversed on the Rocher River, which extends twenty-five miles between here and Peace mouth. To meet this, I hired Colin Fraser's steamer. We left Chipewyan at 6.15 ; at 11.15 camped below the Peace on Great Slave River, and bade farevvell to the stcamer.

The reader may well be puzzled by these numerous names; the fact is the Mackenzie, the Slave, the Peace, the Rocher, and the Unchaga are all one and the same river, but, unfortunately, the early explorers thought proper to give it a new name each time it did something, such as expand into a lake. By rights it should be the Unchaga or Unjiza,

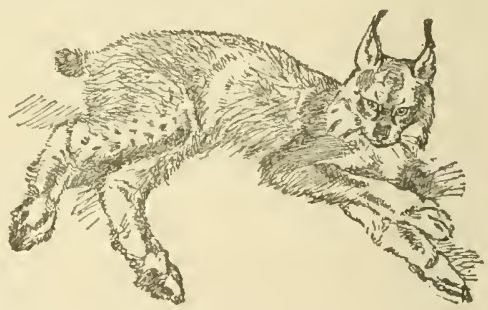

Female Lynx. June 6, 1907 from the Rockics to the Arctic, with the Athabaska as its principal southern tributary.

The next day another Lynx was collected. In its stomach were remains of a Redsquirrel, a Chipmunk, and a Bog-lemming. The last was important as it made a new record. 
The Athabaska is a great river, the Peace is a greater, and the Slave, formed by their union, is worthy of its parents. Its placid flood is here nearly a mile wide, and its banks are covered with a great continuous forest of spruce trees of the largest size. How far back this extends I do not know, but the natives say the best timber is along the river.

More than once a Lynx was seen trotting by or staring at us from the bank, but no other large animal.

On the night of June 7 we reached Smith Landing.

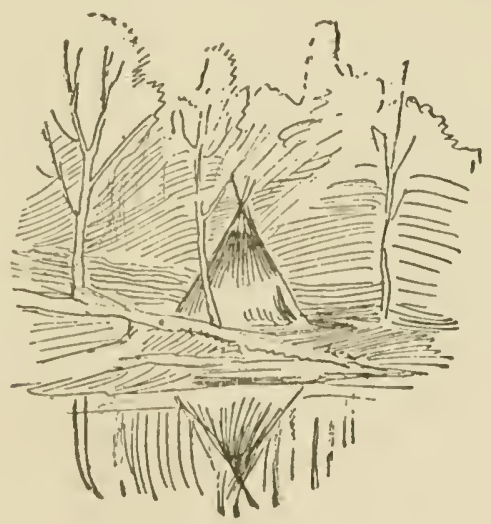




\section{CHAPTER V}

\section{A CONFERENCE WITH THE CHIEFS}

A FEw bands of Buffalo are said to exist in the country east of Great Slave River. Among other matters, Major Jarvis had to report on these, find out how many were left, and exactly where they were. When he invited me to join his expedition, with these questions in view, I needed no pressing.

Our first business was to get guides, and now our troubles began.

Through the traders we found four natives who knew the Buffalo range-they were Kiya, Sousi, Kirma, and Peter Squirrel. However, they seemed in no way desirous of guiding any one into that country. They dodged and delayed and secured many postponements, but the Royal Mounted Police and the Hudson's Bay Company are the two mighty powers of the land, so, urged by an officer of each, these worthies sullenly assembled to meet us in Sousi's cabin.

Sousi, by the way, is Chipewyan for Joseph, and this man's name was Joseph Beaulieu. Other northern travellers have warned all that came after them to beware of the tribe of Beaulieu, so we were on guard.

Sullen silence greeted us as we entered; we could feel their covert antagonism. Jarvis is one of those affable, good-tempered individuals that most persons take for "easy." In some ways he may be so, but I soon real- 


\section{A CONFERENCE WITH THE CHIEFS 37}

ised that he was a keen judge of men and their ways, and he whispered to me: "They mean to block us if possible." Sousi understood French and had some English, but the others professed ignorance of everything but Chipewyan. So it was necessary to call in an interpreter. How admirably he served us may be judged from the following sample secured later.

Q. Are the Buffalo near?

A. Wah-hay-uas-ki busquow Kai-ah taw nip-ee-watchow-es-kee nee-moy-ah. Kee-as-o-win sug-ee-meesh i-mush-wa mus-tat-e-muck ne-mow-ah pe-muk-te-ok nemoy-ah dane-tay-tay-ah.

Interpreter. He say "no."

Q. How long would it take to get them?

A. Ne-moy-ah mis-chay-to-ol Way-hay-o ay-ow-ok-iman-kah-mus-to-ok. Mis-ta-hay cha-gow-os-ki wah-hay-o musk-ee-see-seepi. Mas-kootch e-goot-ah-i-ow mas-kootch ne-moy-ah muk-e-boy sak-te-muk mas-kootch gahk-sinnow ne-moy-ah gehk-kee-win-tay dam-foole-Inglis.

Interpreter. He say "don't know."

$Q$. Can you go with us as guide?

A. Kee-ya-wah-lee nas-bah a-lash-tay wah-lee-lee lan-day. (Answer literally) "Yes, I could go if I could leave the transport."

Interpreter's answer, "Mebby."

After a couple of hours of this bootless sort of thing we had made no headway toward getting a guide, nor could we get definite information about the Buffaloes or the Wolves. Finally the meeting suffered a sort of natural disintegration.

Next day we tried again, but again there were 
technical difficulties, grown up like mushrooms over night.

Kiya could not go or lend his horses, because it was mostly Squirrel's country, and he was afraid Squirrel would not like it. Squirrel could not go because it would be indelicate of him to butt in after negotiations had been opened with Kiya. Kirma was not well. Sousi could not go because his wife was sick, and it preyed on his mind so that he dare not trust himself away from the settlement; at least, not without much medicine to fortify him against rheumatism, home-sickness, and sadness.

Next day Kiya sent word that he had business of great moment, and could not meet us, but would see that early in the morning Squirrel was notified to come and do whatever we wished. In the morning Squirrel also had disappeared, leaving word that he had quite overlooked a most important engagement to "portage some flour across the rapids," not that he loved the tump line, but he had "promised," and to keep his word was very precious to him.

Jarvis and I talked it over and reviewed the information we had. At Ottawa it was reported that the Wolves were killing the calves, so the Buffalo did not increase. At Winnipeg the Wolves were so bad that they killed yearlings; at Edmonton the cows were not safe.

At Chipewyan the Wolves, reinforced by large bands from the Barren Grounds, were killing the young Buffalo, and later the cows and young bulls. At Smith's Landing the Wolves had even tackled an old bull whose head was found with the large bones. Horses 
and dogs were now being devoured. Terrible battles were taking place between the dark Wolves of Peace River and the White Wolves of the Barrens for possession of the Buffalo grounds. Of course the Buffalo were disappearing; about a hundred were all that were left.

But no one ever sees any of these terrible Wolves, the few men who know that country have plenty of pemmican, that is neither Moose nor Caribou, and the Major briefly summed up the situation: "The Wolves are indeed playing havoc with the Buffalo, and the ravenous leaders of the pack are called Sousi, Kiya, Kirma, and Squirrel."

Now of all the four, Sousi, being a Beaulieu and a half-breed, had the worst reputation, but of all the four he was the only one that had admitted a possibility of guiding us, and was to be found on the fifth morning. So his views were met, a substitute found to watch his fishing nets, groceries to keep his wife from pining during his absence, a present for himself, the regular rate of wages doubled, his horses hired, his rheumatism, home-sickness, and sadness provided against, a present of tobaceo, some more presents, a promise of reward for every Buffalo shown, then another present, and we set out.

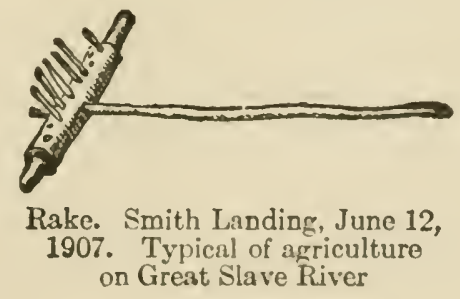




\section{CHAPTER VI}

\section{OU'T WITH SOUSI BEAULIEU}

IT's a fine thing to get started, however late in the day, and though it was 3.20 P. M. before everything was ready, we gladly set out-Sousi, Major Jarvis, and myself-all mounted, the native leading a pack-horse with provisions.

And now we had a chance to study our guide. A man's real history begins, of course, about twenty years before he is born. In the middle of the last century was a notorious old ruffian named Beaulieu. Montreal was too slow for him, so he invaded the north-west with a chosen crew of congenial spirits. His history can be got from any old resident of the north-wwest. I should not like to write it as it was told to me.

His alleged offspring are everywhere in the country, and most travellers on their return from this region, sound a note of warning: "Look out for every one of the name of Beaulieu. They are a queer lot." And now we had committed ourselves and our fortunes into the hands of Beaulieu's second or twenty-second son-I could not make sure which. He is a typical half-breed, of medium height, thin, swarthy, and very active, although he must be far past 60 . Just how far is not 
known, whether 5969 or 79 , he himself seemed uncertain, but he knows there is a 9 in it. The women of Smith's Landing say 59, the men say 79 or \$9.

He is clad in what might be the cast-off garments of a white tramp, except for his beaded moccasins. However sordid these people may be in other parts of their attire, I note that they always have some redeeming touch of color and beauty about the moc-

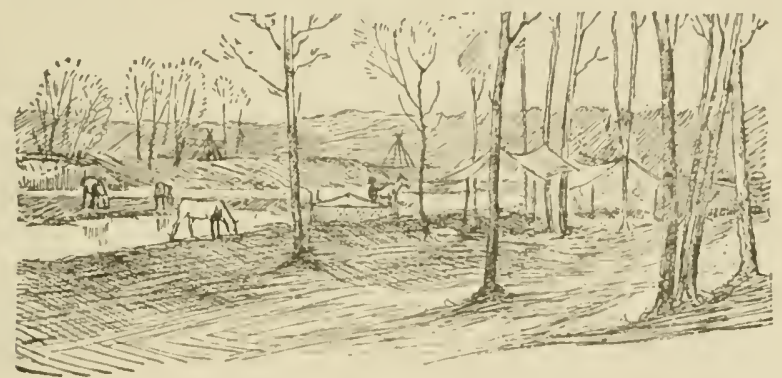

Camp on Salt River. June 13, 1907

casins which cover their truly shapely fect. Sousi's rifle, a Winchester, also was clad in a native mode. An embroidered cover of moose leather protected it night and day, exeept when actually in use; of his weapons he took most scrupulous care. Unlike the founder of the family, Sousi has no children of his own. But he has reared a dozen waifs under prompting of his own kind heart. He is quite a character-does not drink or smoke, and I never lieard him swear. This is not because he does not know how, for he is conversant with the vigor of all the five languages of the country, and the garment of his thought is like Joseph's coat. Ethnologically speaking, its breadth and sub- 
stance are French, but it bears patches of English, with flowers and frills, strophes, and classical allusions of Cree and Chipewyan - the last being the language of his present "home circle."

There was one more peculiarity of our guide that struck me forcibly. He was forever considering his horse. Whenever the trail was very bad, and half of it was, Sousi dismounted and walked-the horse usually following freely, for the pair were close friends.

This, then, was the dark villain against whom we had been warned. How he lived up to his reputation will be seen later.

After four hours' march through a level, swampy country, forested with black and white spruce, black and white poplar, birch, willow, and tamarack, we came to Salt River, a clear, beautiful stream, but of weak, salty brine.

Not far away in the woods was a sweet spring, and here we camped for the night. Close by, on a place recently burnt over, I found the nest of a Green-winged Teal. All cover was gone and the nest much singed, but the down had protected the 10 eggs. The old one fluttered off, played lame, and tried to lead me away. I covered up the eggs and an hour later found she had returned and resumed her post.

That night, as I sat by the fire musing, I went over my life when I was a boy in Manitoba, just too late to see the Buffalo, recalling how I used to lie in some old Buffalo wallow and peer out over the prairie through the fringe of spring anemones and long to see the big brown forms on the plains. Once in those days I got 
a sensation, for I did see them. They turned out to be a herd of common cattle, but still I got the thrill.

Now I was on a real Buffalo hunt, some twenty-five years too late. Will it come? Am I really to see the Wild Buffalo on its native plains? It is too good to be true; too much like tipping back the sands of time.

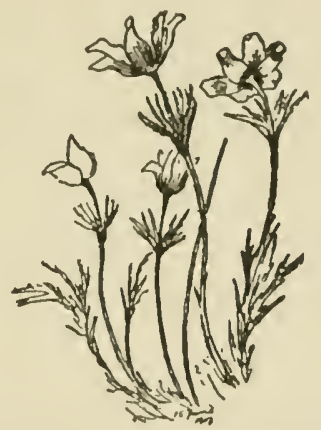

Anemones. June 15, 1907 


\section{CHAPTER VII}

\section{THE BUFFALO HUNT}

We left camp on Salt River at 7.45 in the morning and travelled till 11 o'clock, covering six miles. It was all through the same level country, in which willow swamps alternated with poplar and spruce ridges. At 11 it began to rain, so we camped on a slope under some fine, big white spruces till it cleared, and then continued westward. The country now undulated somewhat and was varied with openings.

Sousi says that when first he saw this region, 30 years ago, it was all open prairie, with timber only in hollows and about water. This is borne out by the facts that all the large trees are in such places, and that all the level open stretches are covered with sapling growths of aspen and fir. This will make a glorious settlement some day. In plants, trees, birds, soil, climate, and apparently all conditions, it is like Manitoba.

We found the skeleton of a cow Buffalo, apparently devoured by Wolves years ago, because all the big bones were there and the skull unbroken.

About two in the afternoon we came up a 200-foot rise to a beautiful upland country, in which the forests were diversified with open glades, and which everywhere showed a most singular feature. The ground is 


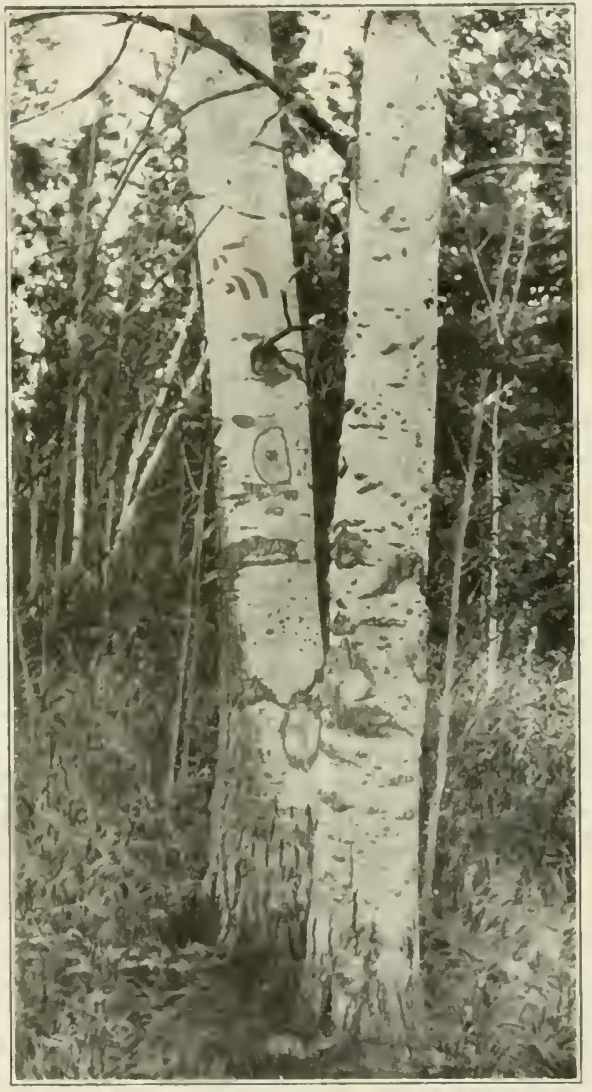

Bear-claw marks on tree 

pitted all over with funnel-shaped holes, from 6 to 40 feet deep, and of equal width across the rim; none of them contained water. I saw one 100 fect across and about 50 feet deep; some expose limestone; in one place we saw granite.

At first I took these for extinct geysers, but later I learned that the whole plateau called Salt Mountain is pitted over with them. Brine is running out of the mountain in great quantities, which means that the upper strata are being unclermined as the salt washes out, and, as these crack, the funnels are formed no doubt by the loose deposits settling.

In the dry woods Bear tracks became extremely numerous; the whole country, indeed, was marked with the various signs. Practically every big tree has bearclaw markings on it, and every few yards there is evidence that the dict of the bears just now is chiefly berries of Uva ursi.

As we rode along Sousi prattled checrfully in his various tongues; but his steady flow of conversation abruptly ended when, about 2 P. ..., we came suddenly on some Buffalo tracks, days old, but still Buffalo tracks. All at once and completely he was the hunter. IIe leaped from his horse and led away like a hound.

Ere long, of course, the trail was erossed by two fresher ones; then we found some dry wallows and several very fresh tracks. We tied up the horses in an old funnel pit and set about an claborate hunt. Jarvis minded the stock, I set out with Sousi, after he had tried the wind by tossing up some grass. But lie stopped, drew a finger-nail sharply across my canvas 
coat, so that it gave a little shriek, and said "Va pa," which is "Cela ne va pas" reduced to its bony framework. I doffed the offending coat and we went forward as shown on the map. The horses were left at $A$; the wind was east. First we circled a little to eastward, tossing grass at intervals, but, finding plenty of new sign, went northerly and westward till most of the

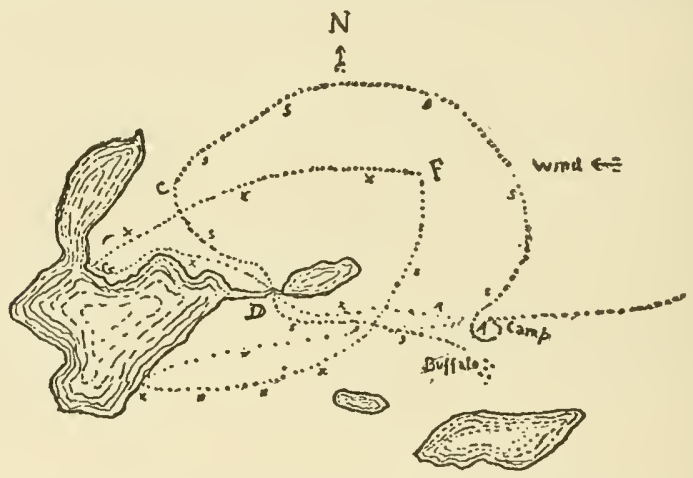

$\mathrm{x} \times \mathrm{x} \times$ course taken when $\mathrm{I}$ got lost. At F I turned back to the lake. s s s shows Sousi's course when stalking the Buffalo

new sign was east of us. Sousi then led for $C$, telling me to step in his tracks and make no noise. I did so for long, but at length a stick cracked under my foot; he turned and looked reproachfully at me. Then a stick cracked under his foot; I gave him a poke in the ribs. When we got to the land between the lakes at $D$, Sousi pointed and said, "They are here." We sneaked with the utmost caution that way-it was impossible to follow any one trail-and in 200 yards Sousi sank to the ground gasping out, "La! la! maintenon faites son portrait au tant que vous voudrez." I 
crawled forward and saw, not one, but half a dozen Buffalo. "I must be nearer," I said, and, lying flat on my breast, crawled, toes and elbows, up to a bush within 75 yards, where I made shot No. 1, and saw here that there were $\delta$ or 9 Buffalo, one an immense bull.

Sousi now cocked his rifle-I said emphatically: "Stop! you must not fire." "No?" he said in aston-

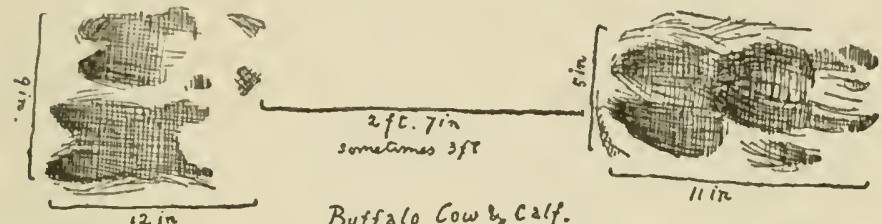

Buffalo Cow \& calf.

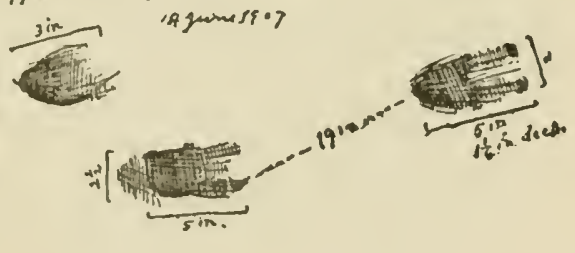

Tracks of Buffalo

ished tones that were full of story and comment. "What did we come for?" Now I saw that by backing out and erawling to another bunch of herbage I could get within 50 yards.

"It is not possible," he gasped.

"Watch me and see," I replied. Gathering all the near vines and twisting them around my neck, I covered my head with leaves and creeping plants, then proceeded to show that it was possible, while Sousi followed. I reached the cover and found it was a bed 
of spring anemones on the far side of an old Buffalo wallow, and there in that wallow I lay for a moment revelling in the sight. All at once it came to me: Now, indeed, was fulfilled the long-deferred dream of my youth, for in shelter of those flowers of my youth, I was gazing on a herd of wild Buffalo. Then slowly I rose above the cover and took my second picture.

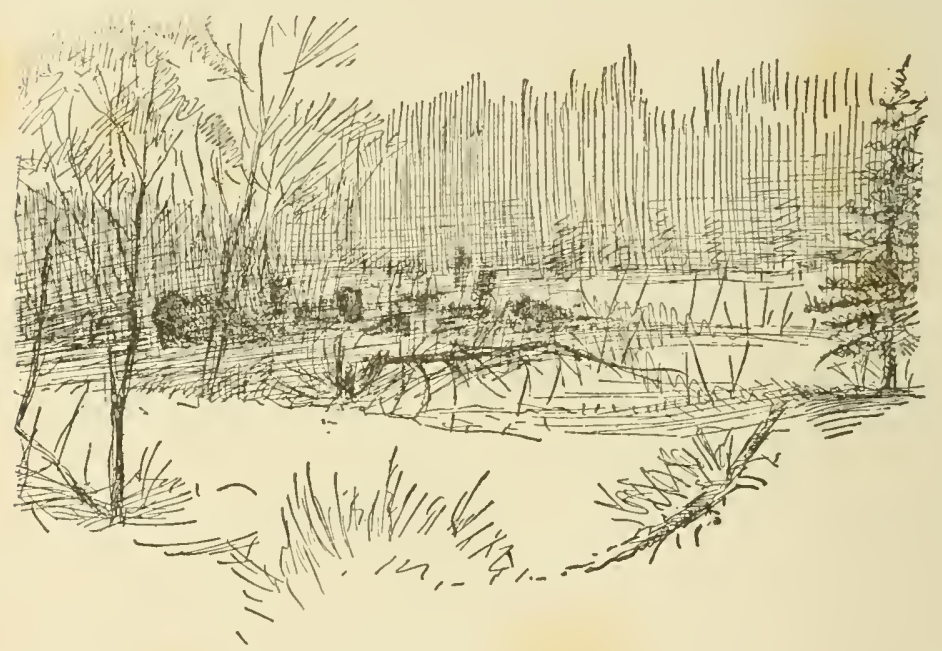

The Buffalo herd

But the watchful creatures, more shy than Moose here, saw the rising mass of herbage, or may have caught the wind, rose lightly and went off. I noticed now, for the first time, a little red calf; ten Buffalo in all I counted. Sousi, standing up, eounted 13. At the edge of the woods they stopped and looked around, but gave no third shot for the camera.

I shook Sousi's hand with all my heart, and he, good old fellow, said: "Ah! it was for this I prayed last 


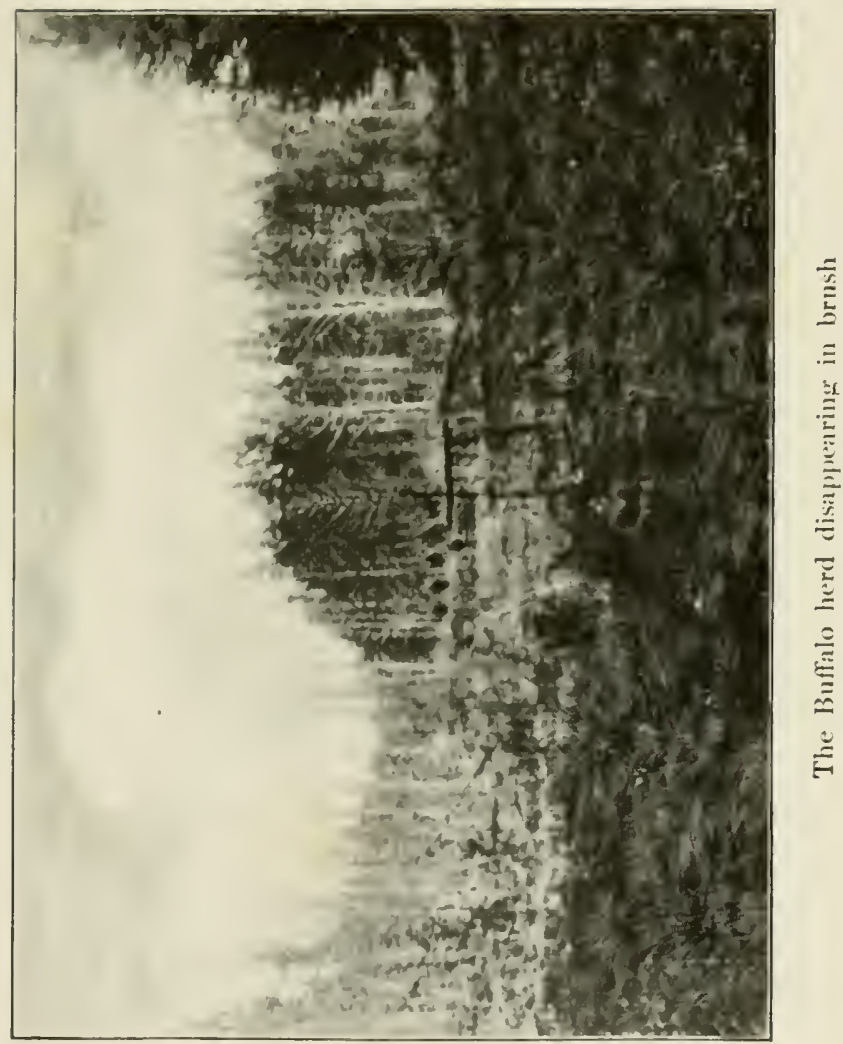



night; without doubt it was in answer to my prayer that the Good God has sent me this great happiness." Then back at camp, 200 yards away, the old man's tongue was loosed, and he told me how the chiefs in conference, and every one at the Fort, had ridiculed him and his Englishmen-"who thought they could walk up to Buffalo and take their pictures."

We had not been long in eamp when Sousi went off to get some water, but at once came running back, shouting excitedly, "My rifle, my rifle!" Jarvis handed it to him; he rushed off to the woods. I followed in time to see him shoot an old Bear and two cubs out of a tree. She fell, sobbing like a human being, "Oh! Oh! Oh-h-h-h!" It was too late to stop him, and he finished her as she lay helpless. The little ones were too small to live alone, so shared her fate.

It seems, as Sousi went to the water hole, he came on an old Bear and her two cubs. She gave a warning "lioff, koff." The only enemies they knew about and feared, were Buffalo, Moose, and Wolves; from these a tree was a safe haven. The cubs scrambled up a tall poplar, then the mother followed. Sousi came shouting in apparent fear; I rushed to the place, thinking he was attacked by something, perhaps a Buffalo bull, but too late to stop the tragedy that followed.

That night he roasted one of the cubs, and as I watched the old cannibal chewing the hands off that little baby Bear it gave me a feeling of disgust for all flesh-eating that lasted for days. Major Jarvis felt much as I did, and old Sousi had exclusive joy in all his bear meat. 
Next morning I was left at camp while Jarvis and Sousi went off to seek for more Buffalo. I had a presentiment that they would find none, so kept the camera and went off to the Lake a mile west, and there made drawings of some tracks, took photos, etc., and on the lake saw about twenty-five pairs of ducks, identified Whitewinged Scoter, Pintail, Green-winged Teal, and Loon. I also watched the manœuvres of a courting Peetweet. He approached the only lady with
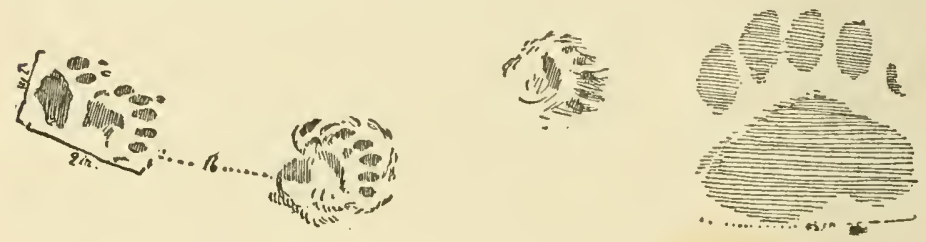

Tracks of the Blackbear

his feathers up and his wings raised; she paid no heed (apparently), but I noticed that when he flew away she followed. I saw a large garter snake striped black and green, and with 2 rows of red spots, one on each side. It was very fat and sluggish. I took it for a female about to lay. Later I learned from Sousi and others that this snake is quite common here, and the only kind found, but in the mountains that lie not far away in the west is another kind, much thicker, fatter, and more sluggish. Its bite is fearfully poisonous, often fatal; "but the Good God has marked the beast by putting a cloche (bell) in its tail."

About 10 I turned campward, but after tramping for nearly an hour I was not only not at home, I was in a totally strange kind of country, covered with a con- 
tinuous poplar woods. I changed my course and tried a different direction, but soon was forced to the conclusion that (for the sixth or seventh time in my life) I was lost.

"Dear me," I said, "this is an interesting opportunity. It comes to me now that I once wrote an essay on 'What 'To Do and What Not To Do When Lost In the Woods.' Now what in the world did I say in it, and which were the things not to do. Yes, I remember now, these were the pieces of advice:

"1st. 'Don't get frightened.' Well, I'm not; I am simply amused.

"2d. 'Wait for your friends to come.' Can't do that; I'm too busy; they wouldn't appear till night.

"3d. 'If you must travel, go back to a place where you were sure of the way.' That means back to the lake, which I know is due west of the camp and must be west of me now."

So back I went, carefully watching the sun for guidance, and soon realised that whenever I did not, I swung to the left. After nearly an hour's diligent travel I did get back to the lake, and followed my own track in the margin to the point of leaving it; then, with a careful corrected bearing, made for camp and arrived in 40 minutes, there to learn that on the first attempt I had swung so far to the left that I had missed camp by half a mile, and was half a mile beyond it before I knew I was wrong. (See map on p. 46.)

At noon Jarvis and Sousi came back jubilant; they had seen countless Buffalo trails, had followed a large bull and cow, but had left them to take the trail of a 
considerable Band; these they discovered in a lake. There were 4 big bulls, 4 little calves, 1 yearling, 3 2 -year-olds, 8 cows. These allowed them to come openly within 60 yards. Then took alarm and galloped off. They also saw a Moose and a Marten-and

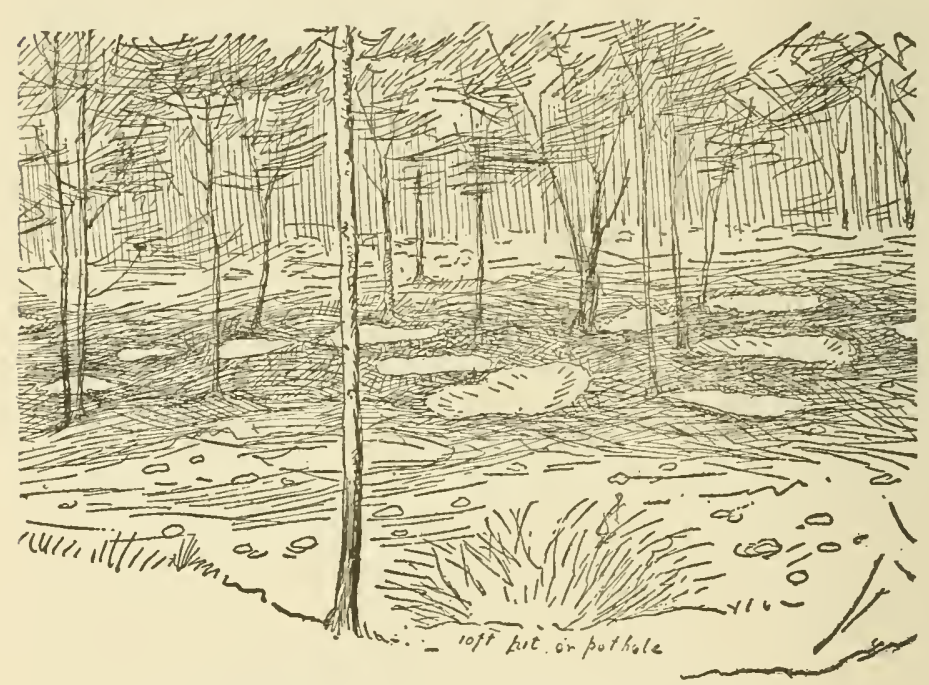

Buffalo dry wallows for the relief from flies

2 Buffalo skeletons. How I did curse my presentiment that prevented them having the camera and securing a really fine photograph!

At 2 P. M. Sousi prepared to break camp. He thought that by going back on our trail he might strike the trail of another herd off to the south-east of the mountain. Jarvis shrewdly suspected that our guide wanted to go home, having kept his promise, won the reward, and got a load of Bear meat. How- 
ever, the native was the guide, we set out in a shower which continued more or less all day and into the night, so we camped in the rain.

Next day it was obvious, and Sousi no longer concealed the fact, that he was making for home as fast as he could go.

At Silt River I found the little Teal back on her eggs in the burnt ground. At 3.30 we reached Smith Landing, having been absent exactly 3 days, and having seen in that time 33 Buffalo, 4 of them calves of this year, 3 old Buffalo skeletons of ancient date, but not a track or sign of a Wolf, not a howl by night, or any evidence of their recent presence, for the buffalo skeletons found were obviously very old.

And our guide-the wicked one of evil ancestry and fame- he was kind, checrful, and courteous throughout; he did exactly as he promised, did it on time, and was well pleased with the pay we gave him. Speak as you find. If ever I revisit that country I shall be glad indeed to secure the services of good old Sousi, even if he is a Beaulieu. 


\section{CHAPTER VIII}

\section{THOMAS ANDERSON}

We were now back at Smith Landing, and fired with a desire to make another Buffalo expedition on which we should have ampler time and cover more than a mere corner of the range. We aimed, indeed, to strike straight into the heart of the Buffalo country. The same trouble about guides arose. In this case it was less acute, because Sousi's account had inspired considerably more respect. Still it meant days of delay which, however, I aimed to make profitable by investigations near at hand.

After all, the most interesting of creatures is the two-legged one with the loose and changeable skin, and there was a goodly colony of the kind to choose from. Most prominent of them all was Thomas Anderson, the genial Hudson's Bay Company officer in charge of the Mackenzie River District. His headquarters are at Fort Smith, 16 miles down the river, but his present abode was Smith Landing, where all goods are landed for overland transport to avoid the long and dangerous navigation on the next 16 miles of the broad stream. Like most of his official brethren, he is a Scotchman; he was born in Nairn, Scotland, in 1848. At 19 he came to the north-west in service of 

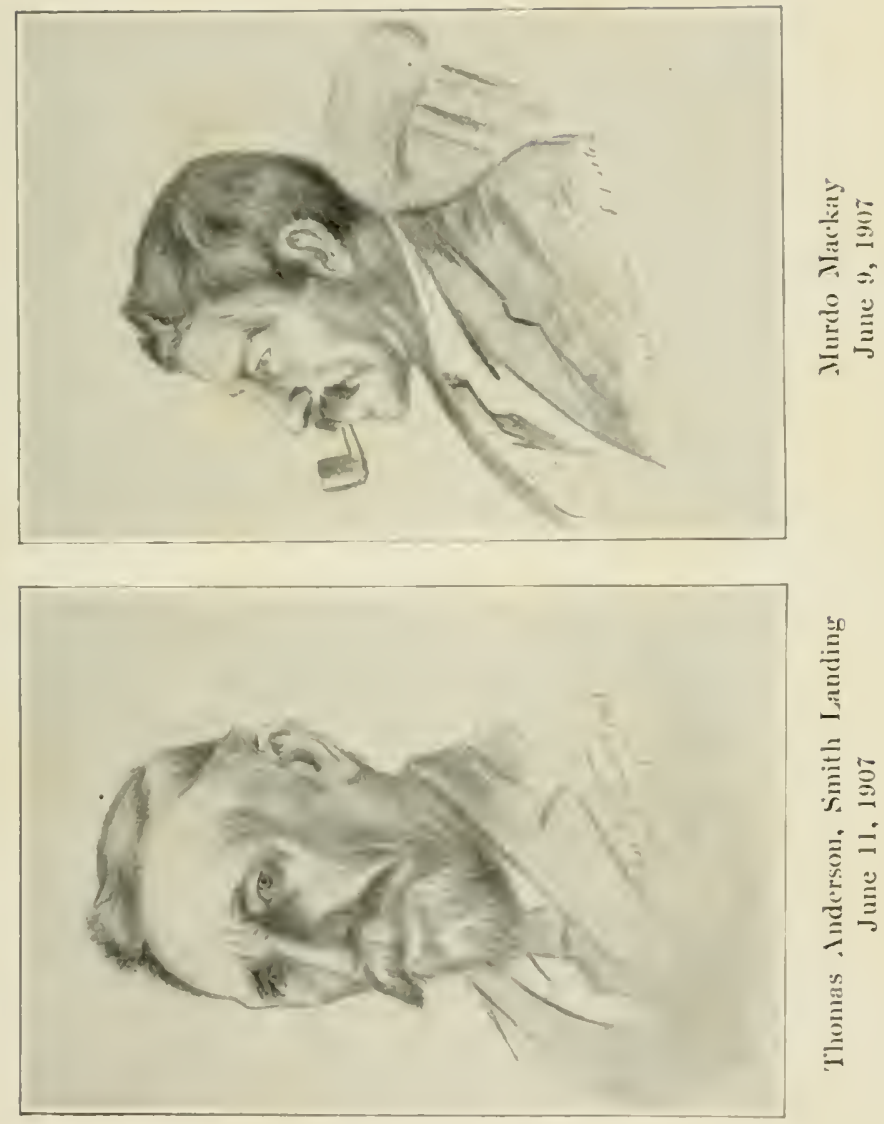

the company, and his long and adventurous life, as he climbed to his present responsible position, may be thus skeletonised:

He spent six months at Fort Temiscamingue,

1 year at Grand Lac,

3 years at Kakabonga,

5 years at Hunter's Lodge, Chippeway,

10 years at Abitibi,

3 years at Dunvegan, Peace River,

1 year at Lesser Slave Lake,

2 months at Savanne, Fort William,

10 years at Nipigon House,

3 years at Isle à la Crosse,

4 years on the Mackenzic River, chiefly at Fort Simpson,

6 months at Fort Smith.

Which tells little to the cars of the big world, but if we say that he spent 5 years in Berlin, then was moved for 3 years to Gibraltar, 2 years to various posts on the Rhine, whence he went for 4 years to St. Petersburg; thence to relieve the officer in charge of Constantinople, and made several flying visits to Bombay and Pekin, we shall have some idea of his travels, for all were afoot, on dogsled, or by canoe.

What wonderful opportunities he had to learn new facts about the wood folk-man and beast-and how little he knew the value of the glimpses that he got! I made it my business to gather all I could of his memories, so far as they dwclt with the things of my world, and offer now a résumé of his more in. 
teresting observations on hunter and hunted of the North. ${ }^{1}$

The following are among the interesting animal notes:

Cougar. Ogushen, the Indian trapper at Lac des Quinze, found tracks of a large cat at that place in the fall of 1879 (?). He saw them all winter on South Bay of that Lake. One day he came on the place where it had killed a Caribou. When he came back about March he saw it. It came toward him. It was evidently a cat longer than a Lynx and it had a very long tail, which swayed from side to side as it walked. He shot it dead, but feared to go near it believing it to be a Wendigo. It had a very bad smell. Anderson took it to be a Puma. It was unknown to the Indian. Ogushen was a first-class hunter and Anderson firmly believes he was telling the truth. Lac des Quinze is 15 miles north of Lake Temiscamingue.

Seals. In old days, he says, small seals were found in Lake Ashkeek. This is 50 miles north-east from Temiscamingue. It empties into Kippewa River, which empties into Temiscamingue. He never saw one, but the Indians of the vicinity told of it as a thing which commonly happened 50 or 60 years ago. Ashkeek is Ojibwa for seal. It is supposed that they wintered in the open water about the Rapids.

White Foxes, he says, were often taken at Cree Lake. Indeed one or two were captured each year. Cree Lake is 190 miles south-cast of Fort Chipewyan. They

${ }^{1}$ Since these notes were made, Thomas Anderson has "crossed the long portage." 
are also taken at Fort Chipewyan from time to time. One was taken at Fondulae, east end of Lake Athabaska, and was traded at Smith Landing in 1906. They are found regularly at Fondulac, the east end of Great Slave Lake, cach year.

In the winter of 1SS5-6 he was to be in charge of Nipigon House, but got orders beforehand to visit the posts on Albany River. He set out from Fort Willian on Lake Superior on his 1,200-mile trip through the snow with an Indian whose name was Joe Eskimo, from Manitoulin Island, 400 miles away. At Nipigon House he got another guide, but this one was in bad shape, spitting blood. After three days' travel the guide said: "I will go to the end if it kills me, because I have promised, unless I ('an get you a better guide. At Wayabimika (Lake Savanne) is an old man named Omeegi; he knows the road better than I do." When they got there, Omeegi, although very old and halfblind, was willing to go on condition that they should not walk too fast. 'Then they started for Osmaburgh House on Lake St. Joseph, 150 miles away. The old man led off well, evidently knew the way, but sometimes would stop, cover his eyes with his hands, look at the ground and then at the sky, and turn on a sharp angle. He proved a fine guide and brought the expedition there in good time.

Next winter at Wayabimika (where Charley de la Ronde ${ }^{1}$ was in charge, but was leaving on a trip of 10 days) Omeegi came in and asked for a present- "a new shirt and a pair of pants." This is the usual

$$
\text { i cisunt de la Ronde. }
$$


outfit for a corpse. He explained that he was to die before Charley came back; that he would die "when the sun rose at that island" (a week ahead). He got the clothes, though every one laughed at him. A week later he put on the new garments and said: "To-day I die when the sun is over that island!" He went out, looking at the sun from time to time, placidly smoking. When the sun got to the right place he came in, lay down by the fire, and in a few minutes was dead.

We buried him in the ground, to his brother's great indignation when he heard of it. He said: "You white men live on things that come out of the ground, and are buried in the ground, and properly, but we Indians live on things that run above ground, and want to take our last sleep in the trees."

Another case of Indian clairvoyance ran thus: About 1879, when Anderson was at Abitibi, the winter packet used to leave Montreal, January 2, each year, and arrive at Abitibi January 19. This year it did not come. The men were much bothered as all plans were upset. After waiting about two weeks, some of the Indians and half-breeds advised Anderson to consult the conjuring woman, Mash-kou-tay Ish-quay (Prairie woman, a Flathead from Stuart Lake, B. C.). He went and paid her some tobacco. She drummed and conjured all night. She came in the morning and told him: "The packet is at the foot of a rapid now, where there is open water; the snow is deep and the travelling heary, but it will be here to-morrow when the sun is at that point."

Sure enough, it all fell out as she had told. This 
woman married a Huclson's Bay man named MacDonald, and he brought her to Lachine, where she bore hin 3 sons; then he died of small-pox, and Sir George Simpson gave orders that she should be sent up to Abitibi and there pensioned for as long as she lived. She was about 75 at the time of the incident. She many times gave evidence of clairvoyant power. The priest said he "knew about it, and that she was helped by the devil."

A gruesome picture of Indian life is given in the following incident.

One winter, 40 or 50 years ago, a band of Algonquin Indians at Wayabimika all starved to death except one squaw and her baby; she fled from the eamp, carrying the child, thinking to find friends and help at Nipigon House. She got as far as a small lake near Deer Lake, and there discovered a cache, probably in a tree. This contained one small bone fish-hook. She rigged up a line, but had no bait. The wailing of the baby spurred her to action. No bait, but she had a knife; a strip of flesh was quickly cut from her own leg, a hole made through the ice, and a fine jack-fish was the food that was sent to this devoted mother. She divided it with the child, saving only enough for bait. She stayed there living on fish until spring, then safely rejoined her people.

The boy grew up to be a strong man, but was cruel to his mother, leaving her finally to die of starvation. Anderson knew the woman; she showed him the scar where she cut the bait.

A piece of yet more ancient history was supplied him in Northern Ontario, and related to me thus: 
Anderson was going to Kakabonga in June, 1879, and camped one night on the east side of Birch Lake on the Ottawa, about 50 miles north-east of Grand Lake Post.

He and his outfit of two canoes met Pah-pah-tay, chief of the Grand Lake Indians, travelling with his family. He called Anderson's attention to the shape of the point which had one good landing-place, a little sandy bay, and told him the story he heard from his people of a battle that was fought there with the Iroquois long, long ago.

Four or five Iroquois war-canoes, filled with warriors, came to this place on a foray for scalps. Their canoes were drawn up on the beach at night. They lighted fires and had a war-dance. Three Grand Lake Algonquins, forefathers of Pah-pah-tay, saw the dance from hiding. They cached their canoe, one of them took a sharp flint-"we had no knives or axes then "-swam across to the canoes, and cut a great hole in the bottom of each.

The three then posted themselves at three different points in the bushes, and began whooping in as many different ways as possible. The Iroquois, thinking it a great war-party, rushed to their canoes and pushed off quickly. When they were in deep water the canoes sank and, as the warriors swam back ashore, the Algonquins killed them one by one, saving alive only one, whom they maltreated, and then let go with a supply of food, as a messenger to his people, and to carry the warning that this would be the fate of every Iroquois that entered the Algonquin country. 


\section{CHAPTER IX}

\section{MIOSQUITOES}

Reference to my Smith Landing Journal for June 17 show's the following:

"The Spring is now on in full flood, the grass is high, the trees are fully leaved, flowers are blooming, birds are nesting, and the mosquitoes are a terror to man and beast."

If I were to repeat all the entries in that last key, it would make dreary and painful reading; I shall rather say the worst right now, and heneeforth avoid the subject.

Every travellor in the country agrees that the mosquitoes are a frightful curse. Captain Back, in 1833 (Joumal, p. 117), said that the sand-flies and mosquitocs are the worst of the hardships to which the northern traveller is exposed.

T. Hutchins, over a hundred years ago, said that no one enters the Barren Grounds in the summer, because no man can stand the stinging insects. I had read these various statements, but clid not grasp the idea until I was among them. At Smith Landing, June 7 , mosquitoes began to be troublesome, quite as numerous as in the worst part of the New Jersey marshes. An estimate of those on the mosquito bar over my bed, showed 900 to 1,000 trying to get at me; day and night, without change, the air was ringing with their hum. 
This was early in the season. On July 9, on Nyarling River, they were much worse, and my entry was as follows:

"On the back of Billy's coat, as he sat paddling before me, I counted a round 400 mosquitoes boring away; about as many were on the garments of his head and neck, a much less number on his arms and legs. The air about was thick with them; at least as many more, fully 1,000 , singing and stinging and filling the air with a droning hum. The rest of us were equally pestered.

"The Major, fresh, ruddy, full-blooded, far over 200 pounds in plumpness, is the best feeding ground for mosquitoes I (or they, probably) ever saw; he must be a great improvement on the smoke-dried Indians. No matter where they land on him they strike it rich, and at all times a dozen or more bloated bloodsuckers may be seen hanging like red currants on his face and neck. He maintains that they do not bother him, and scoffs at me for wearing a net. They certainly do not impair his health, good looks, or his perennial goodhumour, and I, for one, am thankful that his superior food-quality gives us a corresponding measure of immunity."

At Salt River one could kill 100 with a stroke of the palm, and at times they obscured the colour of the horses. A little later they were much worse. On 6 square inches of my tent I counted 30 mosquitoes, and the whole surface was similarly supplied; that is, there were 24,000 on the tent and apparently as many more flying about the door. Most of those that bite 
us are killed, but that makes not the slightest perceptible difference in their manners or numbers. They reminded me of the Klondike gold-seekers. Thousands go; great numbers must die a miserable death; not more than one in 10,000 can get away with a load of the coveted stuff, and yet each believes that he is to be that one, and pushes on.

Dr. L. O. Howard tells us that the mosquito rarely goes far from its birthplace. That must refer to the miserable degenerates they have in New Jersey, for these of the north offer endless evidence of power to travel, as well as to resist cold and wind.

On July 21, 1907, we camped on a small island on Great Slave Lake. It was about one-quarter mile long, several miles from mainland, at least half a mile from any other island, apparently all rock, and yet it was swarming with mosquitoes. Here, as elsewhere, they were mad for our blood; those we knocked off and maimed, would crawl up with sprained wings and twisted legs to sting as ficreely as ever, as long as the beak would work.

We thought the stinging pests of the Buffalo country as bad as possible, but they proved mild and scarce compared with those we yet had to meet on the Aretic Barrens of our ultimate goal.

Each day they got worse; soon it became clear that mere adjectives could not convey any idea of their terrors. Therefore I devised a mosquito gauge. I held up a bare hand for 5 seconds by the wateh, then counted the number of borers on the back; there were 5 to 10 . Each day added to the number, and when 
we got out to the Buffalo country, there were 15 to 25 on the one side of the hand and elsewhere in proportion. On the Nyarling, in early July, the number was increased, being now 20 to 40. On Great Slave Lake, later that month, there were 50 to 60 . But when we reached the Barren Grounds, the land of open breezy plains and cold water lakes, the pests were so bad that the hand held up for 5 seconds often showed from 100 to 125 long-billed mosquitoes boling away into the flesh. It was possible to number them only by killing them and counting the corpses. What wonder that all men should avoid the open plains, that are the kingdom of such a scourge.

Yet it must not be thought that the whole country is similarly and evenly filled. There can be no doubt that they flock and fly to the big moving creatures they see or smell. Maybe we had gathered the whole mosquito product of many acres. This is shown by the facts that if one rushes through thick bushes for a distance, into a clear space, the mosquitoes secm absent at first. One must wait a minute or so to gather up another legion. When landing from a boat on the Northern Lakes there are comparatively few, but even in a high wind, a walk to the nearest billtop results in one again moving in a cloud of tormentors. Does not this readiness to assemble at a bait suggest a possible means of destroying them?

Every one, even the seasoned natives, agree that they are a terror to man a1. $\lambda$ beast; but, thanks to our flyproof tents, we sleep immune. During the day I wear my net and gloves, uncomfortably hot, but a blessed 
relief from the torment. It is casy to get used to those coverings; it is impossible to get used to the mosquitoes.

For July $10 \mathrm{I}$ find this note: "The Mosquitoes are worse now than ever before; even Jarvis, Preble, and the Indians are wearing face protectors of some kind. The Major has borrowed Preble's closed net, much to the latter's discomfiture, as he himself would be glad to wear it."

This country has, for 6 months, the finest climate in the world, but $2 \frac{1}{2}$ of these are ruined by the malignancy of the fly plague. Yet it is certain that knowledge will confer on man the power to wipe them out.

No doubt the first step in this direction is a thorough understanding of the creature's life-history. This understanding many able men are working for. But there is another line of thought that should not be forgotten, though it is negative-many animals are immune. Which are they? Our first business is to list them if we would learn the why of immunity.

Frogs are among the happy ones. One day carly in June I took a wood-frog in my hand. The mosquitoes swarmed about. In a few seconds 30 were on my hand digging away; 10 were on my forefinger, $S$ on my thumb; between these was the frog, a creature with many resemblances to man-red blood, a smooth, naked, soft skin, ete.-and yet not a mosquito attacked it. Scores had bled my hand before one alighted on the frog, and it leaped off again as though the ereature were red hot. The experiment repeated with another 
frog gave the same result. Why? It can hardly be because the frog is cold-blooded, for many birds also seem to be immune, and their blood is warmer than man's.

Next, I took a live frog and rubbed it on my hand over an area marked out with lead pencil; at first the place was wet, but in a few seconds dry and rather shiny. I held up my hand till 50 mosquitoes had alighted on it and begun to bore; of these, 4 alighted on the froggy place, 3 at once tumbled off in haste, but one, No. 32 , did sting me there. I put my tongue to the frog's back; it was slightly bitter.

I took a black-gilled fungus from a manure pile to-day, rubbed a small area, and held my hand bare till 50 mosquitoes had settled and begun to sting; 7 of these alighted on the fungus juice, but moved off at once, except the last; it stung, but at that time the juice was dry.

Many other creatures, including some birds, enjoy immunity, but I note that mosquitoes did attack a dead crane; also they swarmed onto a widgeon plucked while yet warm, and bored in deep; but I did not see any filling with blood.

There is another kind of immunity that is equally important and obscure. In the summer of 1904, Dr. Clinton L. Bagg, of New York, went to Newfoundland for a fishing trip. The Codroy country was, as usual, plagued with mosquitoes, but as soon as the party crossed into the Garnish River Valley, a land of woods and swamps like the other, the mosquitoes had dis- 
appeared. Dr. Bagg spent the month of August there, and found no use for nets, dopes, or other means of fighting winged pests; there were none. What the secret was no one at present knows, but it would be a priceless thing to find.

Now, lest I should do injustice to the Northland that will some day be an empire peopled with white men, let me say that there are three belts of mosquito countrythe Barren Grounds, where they are worst and endure for $2 \frac{1}{2}$ months; the spruce forest, where they are bad and continue for 2 months, and the great arable region of wheat, that takes in Athabaska and Saskatchewan, where the flies are a nuisance for 6 or 7 weeks, but no more so than they were in Ontario, Michigan, Manitoba, and formerly England; and where the cultivation of the land will soon reduce them to insignificance, as it has invariably done in other similar regions. It is quite remarkable in the north-west that such plagues are most numerous in the more remote regions, and they disappear in proportion as the country is opened up and settled.

Finally, it is a relief to know that these mosquitoes convey no discase-even the far-spread malaria is unknown in the region.

Why did I not take a "dope" or "fly repellent," ask many of my friends.

In answer I can only say I have never before been where mosquitoes were bad enough to need one. I had had no experience with fly-dope. I had heard that they are not very effectual, and so did not add one to the outfit. I can say now it was a mistake to 
leave any means untried. Next time I carry "dope." The following recipe is highly recommended:

Pennyroyal, one part,
Oil of Tar, " "
Spirits of Camplior, " "

Sweet Oil, or else vaseline, three parts.

Their natural cnemies are numerous; most small birds prey on them; dragon-fiies also, and the latter alone inspire fear in the pests. When a dragon-fly comes buzzing about one's head the mosquitoes move away to the other side, but it makes no considerable difference.

On Buffalo River I saw a boatman or water-spider seize and devour a mosquito that fell within reach; which is encouraging, because, as a rule, the smaller the foe, the deadlier, and the only creature that really affects the whole mosquito nation is apparently at small red parasite that became more and more numerous as the season wore on. It appeared in red lumps on the bill and various parts of the stinger's body, and the victim became very sluggish. Specimens sent to Dr. L. O. Howard, the authority on mosquitoes, elicited the information that it was a fungus, probably new to science. But evidently it is cleadly to the Culex. More power to it, and the cause it represents; we cannot pray too much for its increase.

Now to sum up: after considering the vastness of the region affected-three-quarters of the globe-and the number of diseases these insects communicate, one is inclined to say that it might be a greater boon to 
mankind to extirpate the mosquito than to stamp out tuberculosis. The latter means death to a considerable proportion of our race, the former means hopeless suffering to all mankind; one takes off each year its toll of the weaklings, the other spares none, and in the far north at least has made a hell on earth of the land that for six months of each year might be a human Paradise.

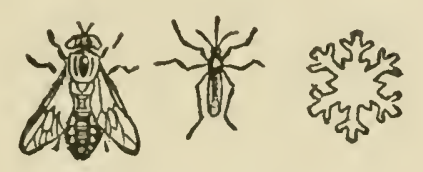

The pests of the Peace 


\section{CHAPTER X}

\section{A BAD CASE}

My unsought fame as a medicine man continued to grow. One morning I heard a white voice outside asking, "Is the doctor in?" Billy replied: "Mr. Seton is inside." On going forth I met a young American who thus introduced himself: "My name is $\mathrm{Y}-$, from Michigan. I was a student at Ann Arbor when you lectured there in 1903. I don't suppose you remember me; I was one of the reception committee; but I'm mighty glad to meet you out here."

After cordial greetings he held up his arm to explain the call and said: "I'm in a pretty bad way."

"Let's see."

He unwound the bandage and showed a hand and arm swollen out of all shape, twice the natural size, and of a singular dropsical pallor.

"Have you any pain?"

"I can't sleep from the torture of it."

"Where does it hurt now?"

"In the hand."

"How did you get it?"

"It seemed to come on after a hard crossing of Lake Athabaska. We had to row all night."

I asked one or two more questions, really to hide my puzzlement. "What in the world is it?" I said to 


\section{A BAD CASE}

myself; "all so fat and puffy." I cudgelled my brain for a clue. As I examined the hand in silence to play for time and conceal my ignorance, he went on:

"What I'm afraid of is blood-poisoning. I couldn't get out to a doctor before a month, and by that time I'll be one-armed or dead. I know which I'd prefer."

Knowing, at all events, that nothing but cvil could come of fear, I said: "Now see here. You can put that clean out of your mind. You never saw bloodpoisoning that colour, did you?"

"That's so," and he seemed intensely relieved.

While I was thus keeping up an air of omniscience by saying nothing, Major Jarvis came up.

"Look at this, Jarvis," said I; "isn't it a bad one?"

"Phew," said the Major, "that's the worst felon I ever saw."

Like a gleam from heaven came the word felon. That's what it was, a felon or whitlow, and again I breathed freely. Turning to the patient with my most cock-sure professional air, I said:

"Now see, Y., you needn't worry; you've hurt your finger in rowing, and the injury was deep and has set up a felon. It is not yet headed up enough; as soon as it is I'll lance it, unless it bursts of itself (and inwardly I prayed it might burst). Can you get any linseed meal or bran?"

"Afraid not."

"Well, then, get some clean rags and keep the place covered with them dipped in water as hot as you car 
stand it, and we'll head it up in twenty-four hours: then in three days I'll have you in good shape to travel." The last sentence, clelivered with the calm certainty of a man who knows all about it and never made a mistake, did so much good to the patient that I caught a reflex of it myself.

He gave me his good hand and said with emotion: "You don't know how much good you have done me. I don't mind being killed, but I don't want to go through life a cripple."

"You say you haven't slept?" I asked.

"Not for three nights; I've suffered too much."

"Then take these pills. Go to bed at ten o'clock and take a pill; if this does not put you to sleep, take another at 10.30. If you are still awake at 11, take the third; then you will certainly sleep."

He went off almost cheerfully.

Next morning he was back, looking brighter. "Well, I said, "you slept last night, all right."

"No," he replied, "I didn't; there's opium in those pills, isn't there?"

"Yes."

"I thought so. Here they are. I made up my mind I'd see this out in my sober senses, without any drugs."

"Good for you," I exclaimed in admiration. "They talk about Indian fortitude. If I had given one of those Indians some sleeping pills, he'd have taken them all and asked for more. But you are the real American stuff, the pluck that can't be licked, and I'll soon have you sound as a dollar." 


\section{A BAD CASE}

Then he showed his immense bladder-like hand. "I'll have to make some preparation, and will operate in your shanty at 1 o'clock," I said, thinking how very professional it sounded.

The preparation consisted of whetting my penknife and, much more important, serewing up my nerves. And now I remembered my friend's brandy, put the flask in my porket, and went to the execution.

He was ready. "Hcre," I said; "take a good pull at this brandy."

"I will not," was the reply. "I'm man enough to go through on my mettle."

"Oh! confound your mettle," I thought, for I wanted an exeuse to take some myself, but could not for shame under the circumstances.

"Are you ready?"

He laid his pudding-y hand on the table.

"You better have your Indian friend hold that hand."

"I'll never budge," he replied, with set teeth, and motioned the Indian away. And I knew he would not flinch. He will never know (till he reads this, perhaps) what an effort it cost me. I knew only I must cut deep enough to reach the pus, not so deep as to touch the artery, and not across the tenclons, and must do it firmly, at one clean stroke. I did.

It was a horrid success. He never quivered, but said: "Is that all? That's a pin-prick to what I've been through every minute for the last week."

I felt faint, went out behind the cabin, and-shall I confess it? - took a long swig of brandy. But I was as 
good as my promise: in three days he was well enough to travel, and soon as strong as ever.

I wonder if real doctors ever conceal, under an air of professional calm, just such doubts and fears as worried me. 


\section{CHAPTER XI}

\section{THE SECOND BUFFALO HUNT}

Thougir so trifling, the success of our first Buffalo hunt gave us quite a social lift. The chiefs were equally surprised with the whites, and when we prepared for a second expedition, Kiya sent word that though he could not act as guide, I should ride his own trained hunter, a horse that could run a trail like a hound, and was without guile.

I am always suspicious of a horse (or man) without guile. I wondered what was the particular weakness of this exceptionally trained, noble, and guileless creature. I have only one prejudice in horse-flesh-I do not like a white one. So, of course, when the hunter arrived he was white as marble, from mane to tail and hoofs; his very eyes were of a cheap china colour, suggestive of cataractine blindness. The only relief was a morbid tinge of faded shrimp pink in his nostrils and ears. But he proved better than he looked. He certainly did run tracks by nose like a hound, provided I let him choose the track. He was a lively walker and easy trotter, and would stay where the bridle was dropped. So I came to the conclusion that Kiya was not playing a joke on me, but really had lent me his best hunter, whose sepulchral whiteness I could see would be of great advantage in snow time when chiefly one is supposed to hunt. 
Not only Kiya, but Pierre Squirrel, the head chief, seemed to harbour a more kindly spirit. He now suddenly acquired a smattering of English and a fair

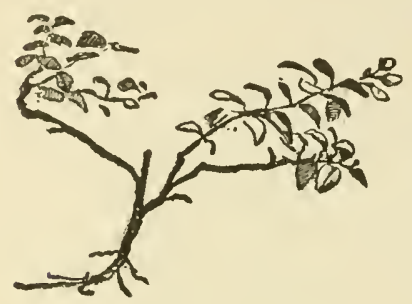

Cranberry knowledge of French. He even agreed to lead us through his own huntinggrounds to the big Buffalorange, stipulating that we be back by July 1 , as that was Treaty Day, when all the tribe assembled to receive their treaty money, and his presence as head chief was absolutely necessary.

We were advised to start from Fort Smith, as the trail thence was through a clryer country; so on the morning of June 24, at 6.50 , we left the Fort on our second Buffalo hunt.

Major A. M. Jarvis, Mr. E. A. Preble, Corporal Selig, Chief Pierre Squirrel, and myself, all mounted, plus two pack-horses, prepared for a week's campaign.

Riding ahead in his yellow caftan and black burnoose was Pierre Squirrel on his spirited

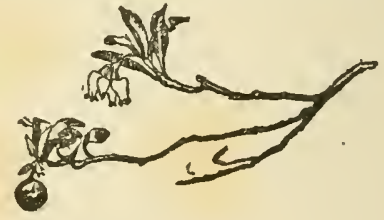

Uva ursi charger, looking most picturesque. But remembering that his yellow caftan was a mosquito net, his black burnoose a Hudson's Bay coat, and his charger an ornery Indian Cayuse, robbed the picture of most of its poetry.

We marched westerly 7 miles through fine, dry, 


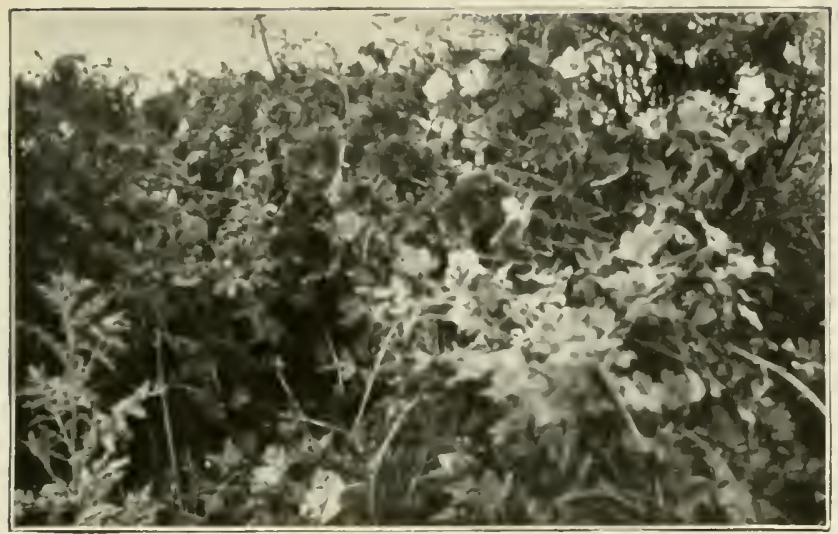

The Athabaska Rose or Needle bloom

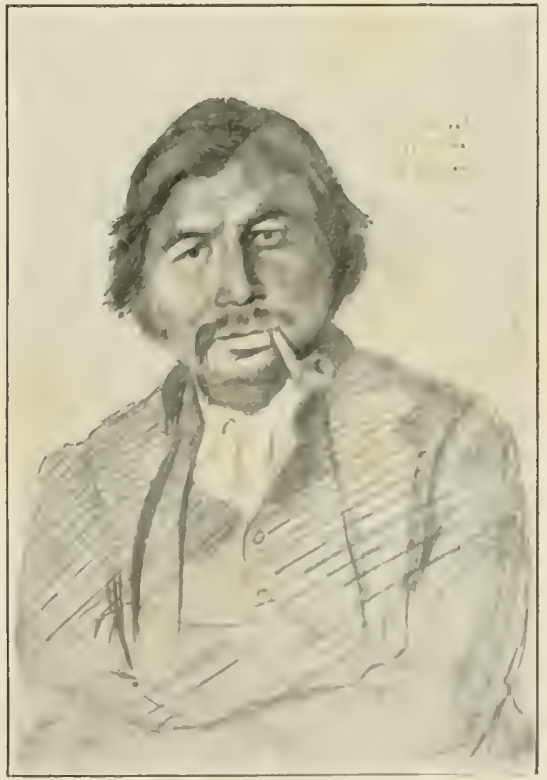

l'ierre Sipuirrel, Chief of the Chipewyans 

jack-pine wood, then 3 miles through mixed poplar, pine, and spruce, and came to the Slave River opposite Point Gravois. Thence we went a mile or so into similar woods, and after another stretch of muskegs. We camper for lunch at 11.45, having covered 12 miles.
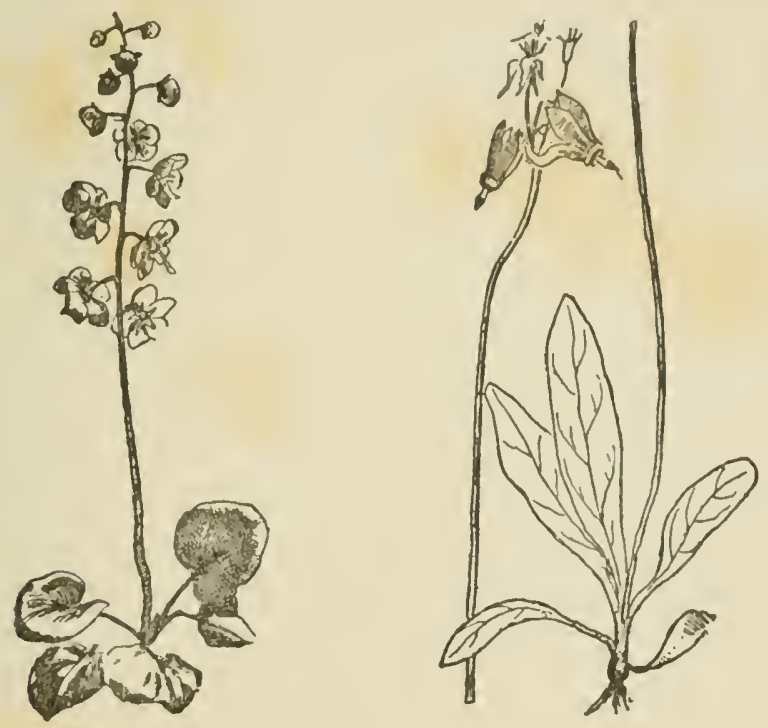

l'yrola

On Salt Mlountain

At two we set out, and reached Salt River at three, but did not eross there. It is a magnificent stream, 200 feet wide, with hard banks and fine timber on each side; but its waters are brackish.

We travelled north-westerly, or northerly, along the east banks for an hour, but at length away from it on a wide prairie, a mile or more across here, but evidently extending much farther behind interruptions of willow clumps. Probably these prairies join with those we 
saw on the Beaulieu trip. They are wet now, though a horse can go anywhere, and the grass is good. We camped about six on a dry place back from the river. At night I was much interested to hear at intervals the

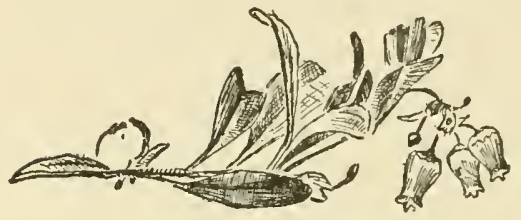

Uva-ursi familiar Kick-kickkick-kick of the Yellow Rail in the adjoining swamps. This must be its northmost range; we did not actually see it.

Here I caught a garter-snake. Preble says it is the same form as that at Edmonton. Our guide was as much surprised to see me take it in my hands, as he was to see me let it go unharmed.

Next morning, after a short hour's travel, we came again to Salt River and proceeded to cross. Evidently Squirrel had selected the wrong place, for the sticky mud seemed bottomless, and we came near losing two of the horses.

After two hours we all got across and went on, but most of the horses had shown up poorly, as spiritless creatures, not yet recovered from the effects of a hard winter.

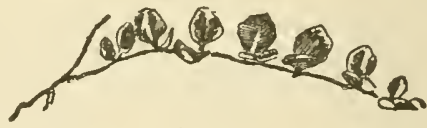

Linnæa

Our road now lay over the high upland of the Salt Mountain, among its dry and beautiful woods. The trip would have been glorious but for the awful things that I am not allowed to mention outside of Chapter IX. 


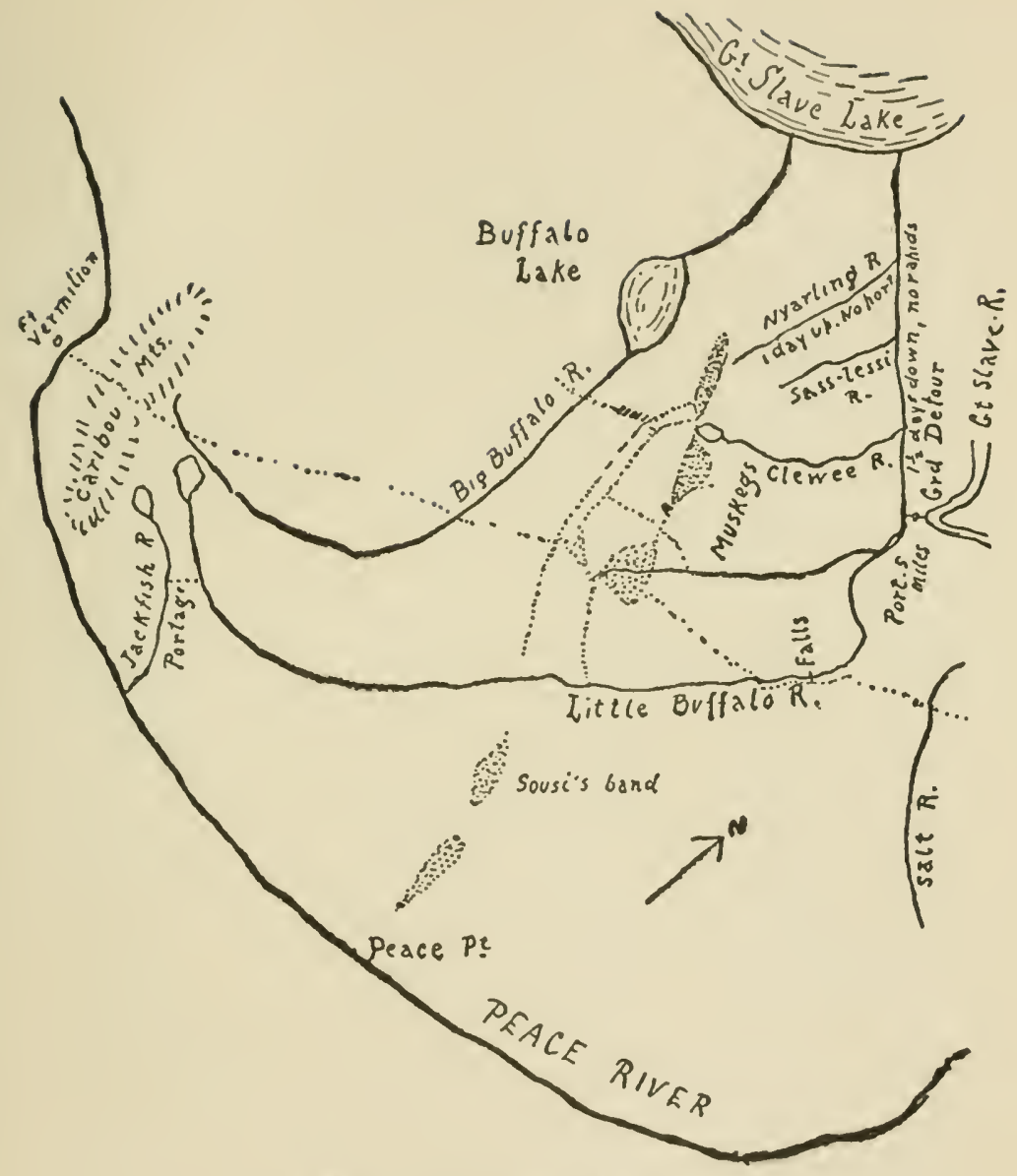

Map of Buffalo herds and trails Drawa by Chlef Pierro Squirrel, Juno 26, 1907 
Pierre proved a pleasant and intelligent companion; he did his best, but more than once shook his head and said: "Chevaux no good."

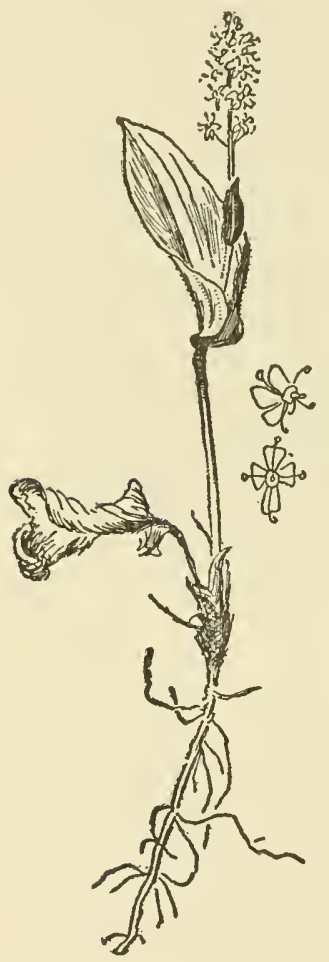

Unifolium

We covered 15 miles before night, and all day we got glimpses of some animal on our track, 300 yards behind in the moods. It might easily have been a Wolf, but at night he sneaked into campa forlorn and starving Indian dog.

Next day we reached the longlooked-for Little Buffalo River. Several times of late Pierre had commented on the slowness of our horses and enlarged on the awful muskegs that covered the country west of the Little Buffalo. Now he spoke out frankly and said we had been $2 \frac{1}{2}$ days coming 40 miles when the road was good; we were now coming to very bad roads and had to go as far again. These horses could not do it, and get him back to Fort Smith for July 1 -and back at any price he must be.

He was willing to take the whole outfit half a day farther westward, or, if we preferred it, he would go afoot or on horseback with the pick of the men and horses for a hasty dash forward; but to take the whole outfit on to the Buffalo country and get back on time was not possible. 
This was a bad shake. We held a council of war, and the things that were said of that Inclian should have riled him if he understood. He preserved his calm demeanour; probably this was one of the convenient times when all his English forsook him. We were simply raging: to be half-way to our goal, with abundance of provisions, fine weather, good health and everything promising well, and then to be balked because our guide wanted to go back.

I felt as savage as the others, but on calmer reflection pointed out that Pierre told us before starting that he must be back for 'Treaty Day, and even now he was ready to do his best.

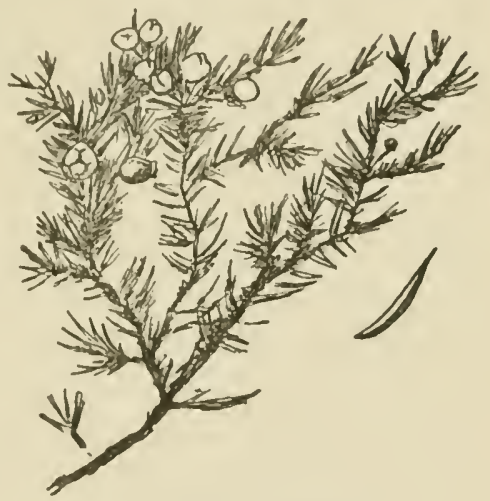

Juniperus nana

Then in a calm of the storm (which he continued to ignore) Pierre turned to me and said: "Why don't you go back and try the canoe route? You can go down the Great River to Grand Detour, then portage 8 miles over to the Buffalo, go down this to the Nyarling, then up the Nyarling into the heart of the Buffalo country; $2 \frac{1}{2}$ days will do it, and it will be easy, for there is plenty of water and no rapids," and he drew a fairly exact map which showed that he knew the country thoroughly.

There was nothing to be gained by going half a day farther. 
To break up our party did not fit in at all with our plans, so, after another brief stormy debate in which the guide took no part, we turned without crossing the Little Buffalo, and silently, savagely, began the homeward journey; as also did the little Indian dog.

Next morning we crossed the Salt River at a lower place where was a fine, hard bottom. That afternoon we travelled for 6 miles through a beautiful and level country, covered with a forest of large poplars, not very thick; it will some day be an ideal cattle-range, for it had rank grass everywhere, and was varied by occasional belts of jack-pine. In one of these Preble found a nest with six eggs that proved to be those of the Bohemian Chatterer. These he secured, with photograph of the nest and old bird. It was the best find of the journey.

The eggs proved of different incubation-at least a week's difference-showing that the cool nights necessitated immediate setting.

We camped at Salt River mouth, and next afternoon were back at Fort Smith, having been out five days and seen nothing, though there were tracks of Moose and Bear in abundance.

Here our guide said good-bye to us, and so did the Indian dog. 


\section{CHAPTER XII}

\section{BEZKYA AND TIIE PILLS}

During this journey I had successfully treated two of the men for slight ailments, and Squirrel had made mental note of the fact. A result of it was that in the morning an old, old, black-looking Indian came hobbling on a stick to my tent and, in husky Chipewyan, roughly translated by Billy, told me that he had pains in his head and his shoulder and his body, and his arms and his legs and his feet, and he couldn't hunt, couldn't fish, couldn't walk, couldn't eat, couldn't lie, couldn't slcep, and he wanted me to tackle the case. I hadn't the least idea of what ailed the old chap, but conveyed no hint of my darkness. I put on my very medical look and said: "Exactly so. Now you take these pills and you will find a wonderful difference in the morning." I had some rather fierce rhubarb pills; one was a dose but, recognising the necessity for éclat, I gave him two.

He gladly gulped them down in water. The Indian takes kindly to pills, it's so easy to swallow them, so obviously productive of results, and otherwise satisfactory. Then the old man hobbled off to his lodge.

A few hours later he was back again, looking older and shakier than ever, his wet red eyes looking like plague spots in his ashy brown visage or like volcanic 
eruptions in a desert of dead lava, and in husky, clicking accents he told Billy to tell the Okimow that the pills were no good-not strong cnough for him.

"Well," I said, "he shall surely have results this time." I gave him three big ones in a cup of hot tea. All the Indians love tea, and it seems to help them. Under its cheering power the old man's tongue was loosened. He talked more clearly, and Billy, whose knowledge of Chipewyan is fragmentary at best, suddenly said:

"I'm afraid I made a mistake. Bezkya says the pills are too strong. Can't you give him something to stop them?"

"Goodness," I thought; "here's a predicament," but I didn't know what to do. I remembered a western adage, "When you don't know a thing to do, don't do a thing." I only said: "Tell Bezkya to go home, go to bed, and stay there till to-morrow, then come here again."

Away went the Indian to his lodge. I felt rather uneasy that day and night, and the next morning looked with some eagerness for the return of Bezkya. But he did not come and I began to grow unhappy. I wanted some evidence that I had not done him an injury. I wished to see him, but professional etiquette forbade me betraying myself by calling on him. Noon came and no Bezkya; late afternoon, and then I sallied forth, not to seek him, but to pass near his lodge, as though I were going to the Hudson's Bay store. And there, to my horror, about the lodge I saw a group of squaws, with shawls over their heads, whispering to- 
gether. As I went by, all turned as one of them pointed at me, and again they whispered.

"Oh, heavens!" I thought; "I've killed the old man." But still I would not go in. That night I did not sleep for worrying about it. Next morning I was on the point of sending Billy to learn the state of affairs, when who should come staggering up but old Bezkya. He was on two erutches now, his complexion was a dirty gray, and his feeble knees were shaking, but he told Billy-yes, unmistakably this time - to tell the Okimow that that was great medicine I had given him, and he wanted a dose just like it for his wife. 


\section{CHAPTER XIII}

\section{FORT SMITH AND THE SOCIAL QUEEN}

Several times during our river journey I heard reference to an extraordinary woman in the lower country, one who gave herself great airs, put on style, who was so stuck up, indeed, that she had "two pots, one for tea, one for coffee." Such incredible pomposity and arrogance naturally invited sarcastic comment from all the world, and I was told I should doubtless see this remarkable person at Fort Smith.

After the return from Buffalo hunt No. 2, and pending arrangements for hunt No. 3, I saw more of Fort Smith than I wished for, but endeavoured to turn the time to account by copying out interesting chapters from the rough semi-illegible, perishable manuscript accounts of northern life called "old-timers." The results of this library research work appear under the chapter heads to which they belong.

At each of these northern posts there were interesting experiences in store for me, as one who had read all the books of northern travel and dreamed for half a lifetime of the north; and that was-almost daily meeting with famous men. I suppose it would be similar if one of these men were to go to London or Washington and have some one tell him: that gentle old man there is Lord Roberts, or that meek, shy, re- 
tiring person is Speaker Cannon; this on the first bench is Lloyd-George, or that with the piereing eyes is Aldrich, the uncrowned King of America. So it was a frequent and delightful experience to meet with men whose names have figured in books of travel for a generation. This was Roderick MacFarlane, who founded Fort Anderson, discovered the MacFarlane Rabbit, etc.; here was John Schott, who guided Caspar Whitney; that was Hanbury's head man; here was Murdo McKay, who travelled with Warburton Pike in the Barrens and starved with him on Peace River; and so with many more.

Very few of these men had any idea of the interest attaching to their observations. Their notion of values centres chiefly on things remote from their daily life. It was very surprising to see how completely one may be outside of the country he lives in. Thus I once met a man who had lived sixteen years in northern Ontario, had had his chickens stolen every year by Foxes, and never in his life had seen a Fox. I know many men who live in Wolf country, and hear them at least every week, but have never seen one in twenty years' experience. Quite recently I saw a score of folk who had lived in the porcupiniest part of the Adirondacks for many summers and yet never saw a Poreupine, and did not know what it was when I brought one into their camp. So it was not surprising to me to find that although living in a country that swarmed with Moose, in a village which consumes at least a hundred Moose per annum, there were at Fort Smith several of the Hudson's Bay men that had lived on Moose meat 
all their lives and yet had never seen a live Moose. It sounds like a New Yorker saying he had never seen a stray cat. But I was simply dumfounded by a final development in the same line.

Quite the most abundant carpet in the forest here is the uva-ursi or bear-berry. Its beautiful evergreen leaves and bright red berries cover a quarter of the ground in dry woods and are found in great acre beds. It furnishes a staple of food to all wild things, birds and beasts, including Foxes, Martens, and Coyotes; it is one of the most abundant of the forest products, and not one hundred yards from the fort are solid patches as big as farms, and yet when I brought in a spray to sketch it one day several of the Hudson's Bay officers said: "Where in the world did you get that? It must be very rare, for I never yet saw it in this country." A similar remark was made about a phœbe-bird. "It was never before seen in the country"; and yet there is a pair nesting every quarter of a mile from Athabaska Landing to Great Slave Lake.

Fort Smith, being the place of my longest stay, was the scene of my largest medical practice.

One of my distinguished patients here was Jacob McKay, a half-breed born on Red River in 1840 . He left there in 1859 to live 3 years at Rat Portage. Then he went to Norway House, and after 3 years moved to Athabaska in 1865 . In 1887 he headed a special government expedition into the Barren Grounds to get some baby Musk-ox skins. He left Fort Rae, April 25, 1887, and, travelling due north with Dogrib Indians some 65 miles, found Musk-ox on May 10, and 


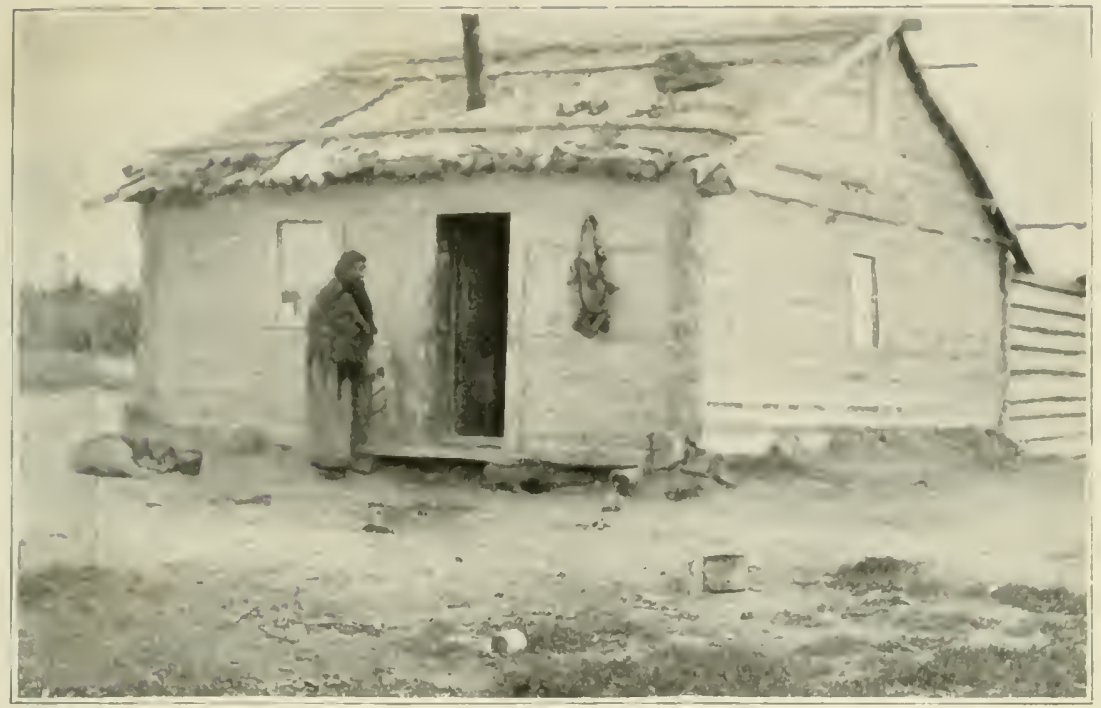

Indian cabin, Fort Smith

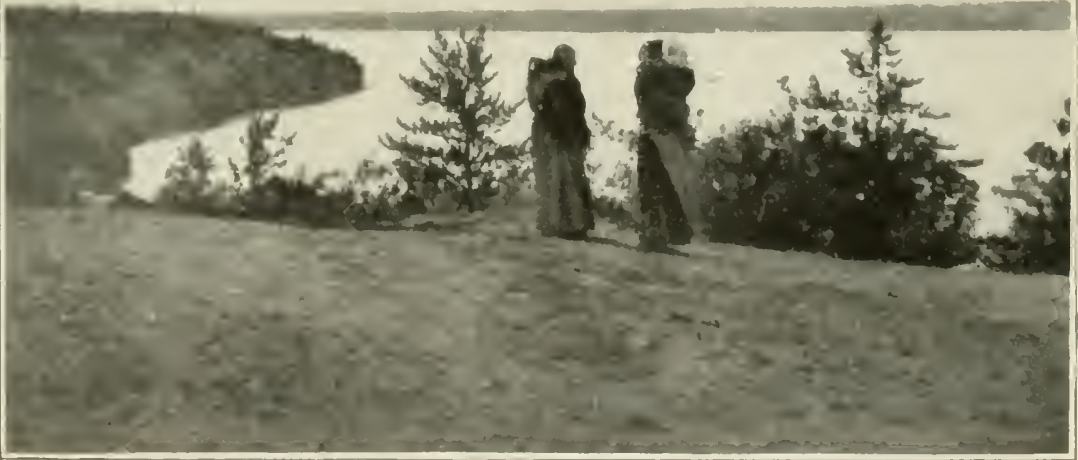

Starving squaws looking for the return of the fisher boats 

later saw many hundreds. 'They killed 16 calves for' their pelts, but no old ones. MeKay had to use all his influence to kecp the Indians from slatightering wholesale; indeed, it was to restrain them that he was sent.

He now lives at Fort Resolution.

One morning the chief came and said he wanted me to doctor a sick woman in his lodge. I thought sick women a good place for an amateur to draw the line, but Squirrel did not. "Il faut venir; elle est bien malade."

At length I took my pill-kit and followed him. Around his lodge were a score of the luuge sled clogs, valuable animals in winter, but useless, sullen, starving, noisy nuisances all summer. If you kick them out of your way, they respect you; if you pity them, they bite you. They respeeted us.

We entered the lodge, and there sitting by the fire were two squaws making moceasins. One was old and ugly as sin; the second, young and pretty as a brown fawn. I looked from one to the other in doubt, and said:

"Laquelle est la malade?"

Then the pretty one replied in perfect English: "You needn't talk French here; I speak English,", which she certainly did. French is mostly used, but the few that speak English are very proud of it and are careful to let you know.

"Are you ill?" I asked.

"The ehief thinks I am," was the somewhat impatient reply, and she broke down in a coughing fit. 
"How long have you had that?" I said gravely. "What?"

I tapped my chest for reply.

"Oh! since last spring."

"And you had it the spring before, too, didn't you?"

"Why, yes! (a pause). But that isn't what bothers me."

"Isn't your husband kind to you?"

"Yes-sometimes."

"Is this your husband?"

"No! F- B- is; I am K-."

Again she was interrupted by coughing.

"Would you like something to ease that cough?" I asked.

"No! It isn't the body that's sick; it's the heart."

"Do you wish to tell me about it?"

"I lost my babies."

"When?"

"Two years ago. I had two little ones, and both died in one month. I am left much alone; my husband is away on the transport; our lodge is nearby. The chief has all these dogs; they bark at every little thing and disturb me, so I lie awake all night and think about my babies. But that isn't the hardest thing." "What is it?"

She hesitated, then burst out: "The tongues of the women. You don't know what a hell of a place this is to live in. The women here don't mind their work; they sit all day watching for a chance to lie about their neighbours. If I am seen talking to you now, a story will be made of it. If I walk to the store for a pound 
of tea, a story is made of that. If I turn my head, another story; and everything is carricd to my husband to make mischief. It is nothing but lies, lies, lies, all day, all night, all year. Women don't do that way in your country, do they?"

"No," I replied emphatically. "If any woman in my country were to tell a lie to make another woman unhappy, she would be thought very, very wicked."

"I am sure of it," she said. "I wish I could go to your country and be at rest." She turned to her work and began talking to the others in Chipewyan.

Now another woman entered. She was dressed in scmi-white style, and looked, not on the ground, as does an Indian woman, on seeing a strange man, but straight at me.

"Bon jour, madame," I said.

"I speak Ingliss," she replied with emphasis.

"Indeed! And what is your name?"

"I am Madame X-."

And now I knew I was in the presence of the stuckup social queen.

After some conversation she said: "I have some things at home you like to see."

"Where is your lodge?" I asked.

"Lodge," she replied indignantly; "I have no lodge. I know ze Indian way. I know ze half-breed way. I know ze white man's way. I go ze white man's way. I live in a house-and my door is painted blue."

I went to her house, a 10 by $12 \log$ cabin; but the door certainly was painted blue, a gorgeous sky blue, the only touch of paint in sight. Inside was all one 
room, with a mud fireplace at one end and some piles of rags in the corners for beds, a table, a chair, and some pots. On the walls snow-shoes, fishing-lines, dried fish in smellable bunches, a portrait of the Okapi from Outing, and a musical clock that played with

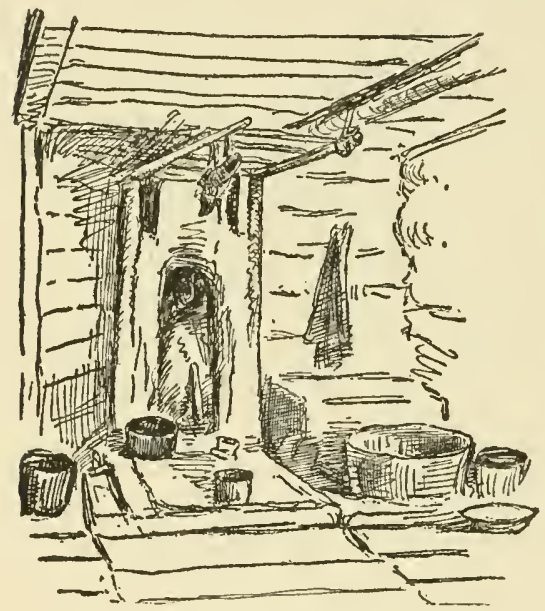

Half-breed's kitchen, Fort Smith painful persistence the first three bars of "God Save the King." Everywhere else were rags, mud, and dirt.

"You see, I am joost like a white woman," said the swarthy queen. "I wear boots (she drew her bare brown feet and legs under her skirt) and corsets. Zey are la," and she pointed to the wall, where, in very truth, tied up with a bundle of dried fish, were the articles in question. Not simply boots and corsets, but high-heeled Louis Quinze slippers and French corsets. I learned afterward how they were worn. When she went shopping to the H. B. Co. store she had to cross the "parade" ground, the great open space; she crowded her brown broad feet into the slippers, then taking a final good long breath she strapped on the fearfully tight corsets outside of all. Now she hobbled painfully across the open, proudly conscious that the eyes of 
the world were upon her. Once in the store she would unhook the corsets and breathe comfortably till the agonized triumphant return parade was in order.

'This, however, is aside; we are still in the home of the queen. She continued to adduce new evidences. "I am just like a white woman. I call my daughter" darrr-leeng." Then turning to a fat, black-looking squaw by the fire, she said: "Darrr-leeng, go feteh a pail of vaw-taire."

But darling, if familiar with that form of address, must have been slumbering, for she never turned or moved a hair's-breadth or gave a symptom of intelligence.

Now, at length it transpired that the social leader wished to see me professionally.

"It is ze nairves," she explained. "Zere is too much going on in this village. I am fatiguée, very tired. I wish I could go away to some quiet place for a long rest."

It was difficult to think of a place, short of the silent tomb, that would be obviously quieter than Fort Smith. So I looked wise, worked on her faith with a pill, assured her that she would soon feel much better, and closed the blue door behind me.

With Chief Squirrel, who had been close by in most of this, I now walked back to my tent. He told me of many sick folk and sad lodges that needed me.

It seems that very few of these people are well. In spite of their healthy forest lives they are far less sound than an average white community. They have their own troubles, with the white man's maladies 
thrown in. I saw numberless other cases of dreadful, hopeless, devastating diseases, mostly of the white man's importation. It is heart-rending to see so much human misery and be able to do nothing at all for it, not even bring a gleam of hope. It made me feel like a murderer to tell one after another, who came to me covered with cankerous bone-eating sores, "I can do nothing"; and I was deeply touched by the simple statement of the Chief Pierre Squirrel, after a round of visits: "You see how unhappy we are, how miserable and sick. When I made this treaty with your government, I stipulated that we should have here a policeman and a doctor; instead of that you have sent nothing but missionaries."

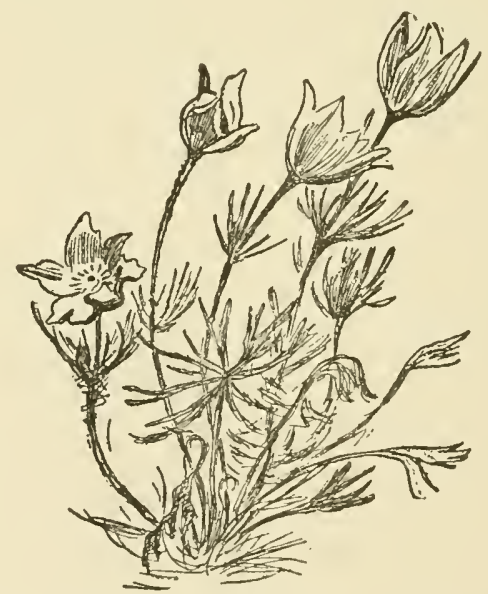

Anemone patens, Slave River, 40 miles above Fort Smith, June 7, 1907 While sketching this a humming-bird moth visited the bloom 


\section{CHAPTER XIV}

\section{RABBITS AND LYNXES IN THE NORTH-WEST}

There are no Rabbits in the north-west. This statement, far from final, is practically true to-day, but I saw plenty of Lynxes, and one cannot write of ducks without mentioning water.

All wild animals fluctuate greatly in their population, none more so than the Snowshoe or white-rabbit of the north-west. This is Rabbit history as far back as known: They are spread over some great area; conditions are favourable; some unknown influence endows the females with unusual fecundity; they bear not one, but two or three broods in a season, and these number not 2 or 3 , but $S$ or 10 each brood. The species increases far beyond the powers of predaceous birds or beasts to check, and the Rabbits after 7 or 8 years of this are multiplied into untold millions. On such occasions every little thicket has a Rabbit in it; they jump out at every $S$ or 10 feet; they number not less than 100 to the acre on desirable ground, which means over 6,000 to the square mile, and a region as large as Alberta would contain not less than 100,000,000 fat white bunnies. At this time one man can readily kill 100 or 200 Rabbits in a day, and every bird and beast of prey is slaughtering Rabbits without restraint. Still they increase. Finally, they are so extraordina- 
rily superabundant that they threaten their own food supply as well as poison all the ground. A new influence appears on the scene; it is commonly called the plague, though it is not one disease but many run epidemic riot, and, in a few weeks usually, the Rabbits are wiped out.

This is an outline of the established routine in Rabbit vital statistics. It, of course, varies greatly in every detail, including time and extent of territory involved, and when the destruction is complete it is an awful thing for the carnivores that have lived on the bunny millions and multiplied in ratio with their abundance. Of all the northern creatures none are more dependent on the Rabbits than is the Canada Lynx. It lives on Rabbits, follows the Rabbits, thinks Rabbits, tastes like Rabbits, increases with them, and on their failure dies of starvation in the unrabbited woods.

It must have been a Hibernian familiar with the north that said: "A Lynx is nothing but an animated Rabbit anyway."

The Rabbits of the Mackenzie River Valley reached their flood height in the winter of 1903-4. That season, it seems, they actually reached billions.

Late the same winter the plague appeared, but did not take them at one final swoop. Next winter they were still numerous, but in 1907 there seemed not one Rabbit left alive in the country. All that summer we sought for them and inquired for them. We saw signs of millions in the season gone by; everywhere were acres of saplings barked at the snow-line; the floor of the woods, in all parts visited, was pebbled over with 
pellets; but we saw not one Woodrabbit and heard only a vague report of 3 that an Indian claimed he had seen in a remote part of the region late in the fall.

Then, since the Lynx is the logical apex of a pyramid of Rabbits, it naturally goes down when the Rabbits are remored.

These bobtailed cats are actually starving and ready to enter any kind of a trap or snare that carries a bait. The slaughter of Lynxes in its relation to the Rabbit supply is shown by the H. B. Company fur returns as follows:

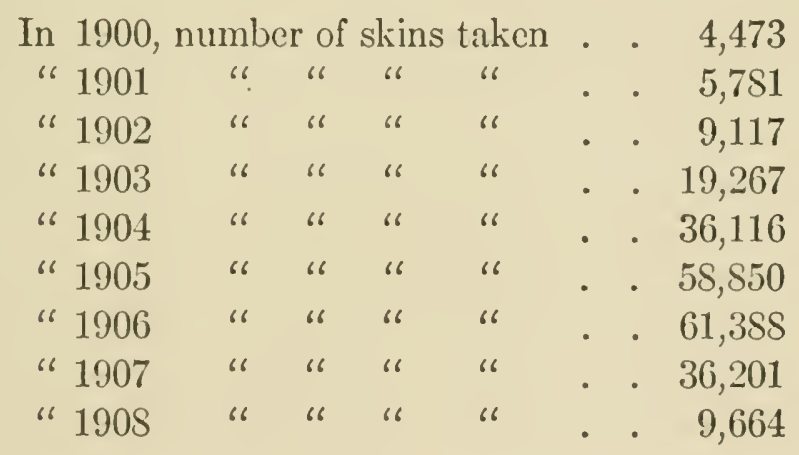

Remembering, then, that the last of the Rabbits were wiped out in the winter of 1906-7, it will be understood that there were thousands of starving Lynxes roaming about the country. The number that we saw, and their conditions, all helped to emphasise the dire story of plague and famine.

Some of my notes are as follows:

May 1Sth, Athabaska River, on roof of a trapper's hut found the bodies of 30 Lynxes. 
May 19th, young Lynx shot to-day, female, very thin, weighed only $12 \frac{1}{2} \mathrm{lbs}$., should have weighed 25 . In its stomach nothing but the tail of a white-footed mouse. Liver somewhat diseased. In its bowels at least one tapeworm.

June 3d, a young male Lynx shot to-day by one of the police boys, as previously recorded. Starving; it weighed only $15 \mathrm{lbs}$.

June 6th, adult female Lynx killed, weighed 15 lbs.; stomach contained a Redsquirrel, a Chipmunk, and a Bog-lemming. (Synaptomys borealis.)

June 18th, young male Lynx, weight 13 lbs., shot by Preble on Smith Landing; had in its stomach a Chipmunk (borealis) and 4 small young of the same, apparently a week old; also a score of pinworms. How did it get the Chipmunk family without digging them out?

June 26th, on Salt Mt. found the dried-up body of a Lynx firmly held in a Bear trap.

June 29th, one of the Jarvis bear-cub skins was destroyed by the dogs, except a dried-up paw, which he threw out yesterday. This morning one of the men shot a starving Lynx in camp. Its stomach contained nothing but the bear paw thrown out last night.

These are a few of my observations; they reflect the general condition-all were starving. Not one of them had any Rabbit in its stomach; not one had a bellyful; none of the females were bearing young this year.

To embellish these severe and skeletal notes, I add some incidents supplied by various hunters of the north. 
Let us remember that the Lynx is a huge eat weighing 25 to 35 or even $40 \mathrm{lbs}$, that it is an ordinary cat multiplied by some 4 or 5 diameters, and we shall have a good foundation for comprehension.

Murdo MeKay has often seen 2 or 3 Lynxes together in March, the mating season. They fight and caterwaul like a lot of tomcats.

The uncatlike readiness of the Lynx to take to water is well known; that it is not wholly at home there is shown by the fact that if one awaits a Lynx at the landing he is making for, he will not turn aside in the least, but come right on to land, fight, and usually perish.

The ancient feud between cat and dog is not forgotten in the north, for the Lynx is the deadly foe of the Fox and habitually kills it when there is soft snow and scarcity of easier prey. Its broad feet are snowshoes enabling it to trot over the surface on Reynard's trail. The latter easily runs away at first, but sinking deeply at each bound, his great speed is done in 5 or 6 miles; the Lynx keeps on the same steady trot and finally claims its victim.

Joln Bellecourt related that in the January of 1907, at a place 40 miles south of Smith Landing, he saw in the snow where a Lynx had run down and devoured a Fox.

A contribution by T. Anderson runs thus:

In late Narch, 1907, an Indian named Amil killed a Caribou near Fort Rae. During his absence a Lynx came along and gorged itself with the meat, then lay down alongside to sleep. A Silver Fox came next; but the Lynx sprang on him and killed him. When 
Amil came back he found the Fox and got a large sum for the skin; one shoulder was torn. He did not see the Lynx but saw the tracks.

The same old-timer is authority for a case in which the tables were turned.

A Desert Indian on the headwaters of the Gatineau went out in the early spring looking for Beaver. At a well-known pond he saw a Lynx crouching on a log, watching the Beaver hole in the ice. The Indian waited. At length a Beaver came up cautiously and crawled out to a near bunch of willows; the Lynx sprang, but the Beaver was well under way and dived into the hole with the Lynx hanging to him. After a time the Indian took a crotched pole and fished about under the ice; at last he found something soft and got it out; it was the Lynx drowned.

Belalise ascribes another notable achievement to this animal.

One winter when hunting Caribou near Fond du Lac with an Indian named Tenahoo (human tooth), they saw a Lynx sneaking along after some Caribou; they saw it coming but had not sense enough to run away. It sprang on the neck of a young buck; the buck bounded away with the Lynx riding, but soon fell dead. The hunters came up; the Lynx ran off. There was little blood and no large wound on the buck; probably its neck was broken. The Indian said the Lynx always kills with its paw, and commonly kills Decr. David MacPherson corroborates this and maintains that on occasion it will even kill Moose.

In southern settlements, where the Lynx is little 
known, it is painted as a fearsome beast of limitless ferocity, strength, and activity. In the north, where it abounds and furnishes staple furs and meat, it is held in no such awe. It is never known to attack man. It often follows his trail out of curiosity, and often the trapper who is so followed gets the Lynx by waiting

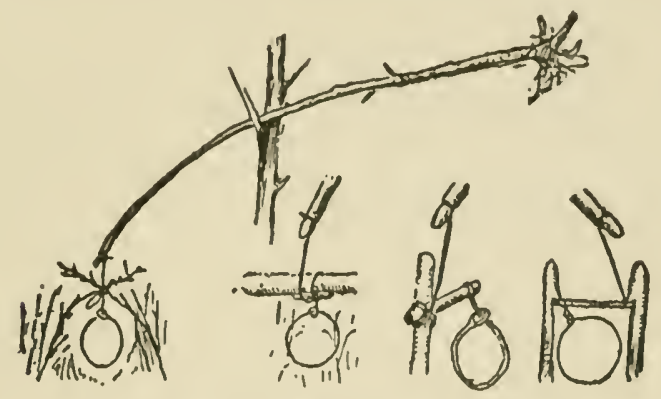

Pole for rabbit snare and various ways of setting the noose

in ambush; then it is easily killed with a charge of duck-shot. When caught in a snare a very small club is used to "add it to the list." It seems tremendously active among logs and brush piles, but on the level ground its speed is poor, and a good runner can overtake one in a few hundred yards.

David MacPherson says that last summer he ran down a Lynx on a prairie of Willow River (Mackenzic), near Providence. It had some 90 yards start; he ran it down in about a mile, then it turned to fight and he shot it.

Other instances have been recorded, and finally, as noted later, I was eye-ritness of one of these exploits. Since the creature can be run down on hard ground, it 
is not surprising to learn that men on snow-shoes commonly pursue it successfully. As long as it trots it is safe, but when it gets alarmed and bounds it sinks and becomes exhausted. It runs in a circle of about a mile, and at last takes to a tree where it is easily killed. At least one-third are taken in this way; it requires half an hour to an hour, there must be soft snow, and the Lynx must be scared so he leaps; then he sinks; if not scared he glides along on his hairy snow-shoes, refuses to tree, and escapes in thick woods, where the men cannot follow quickly. 

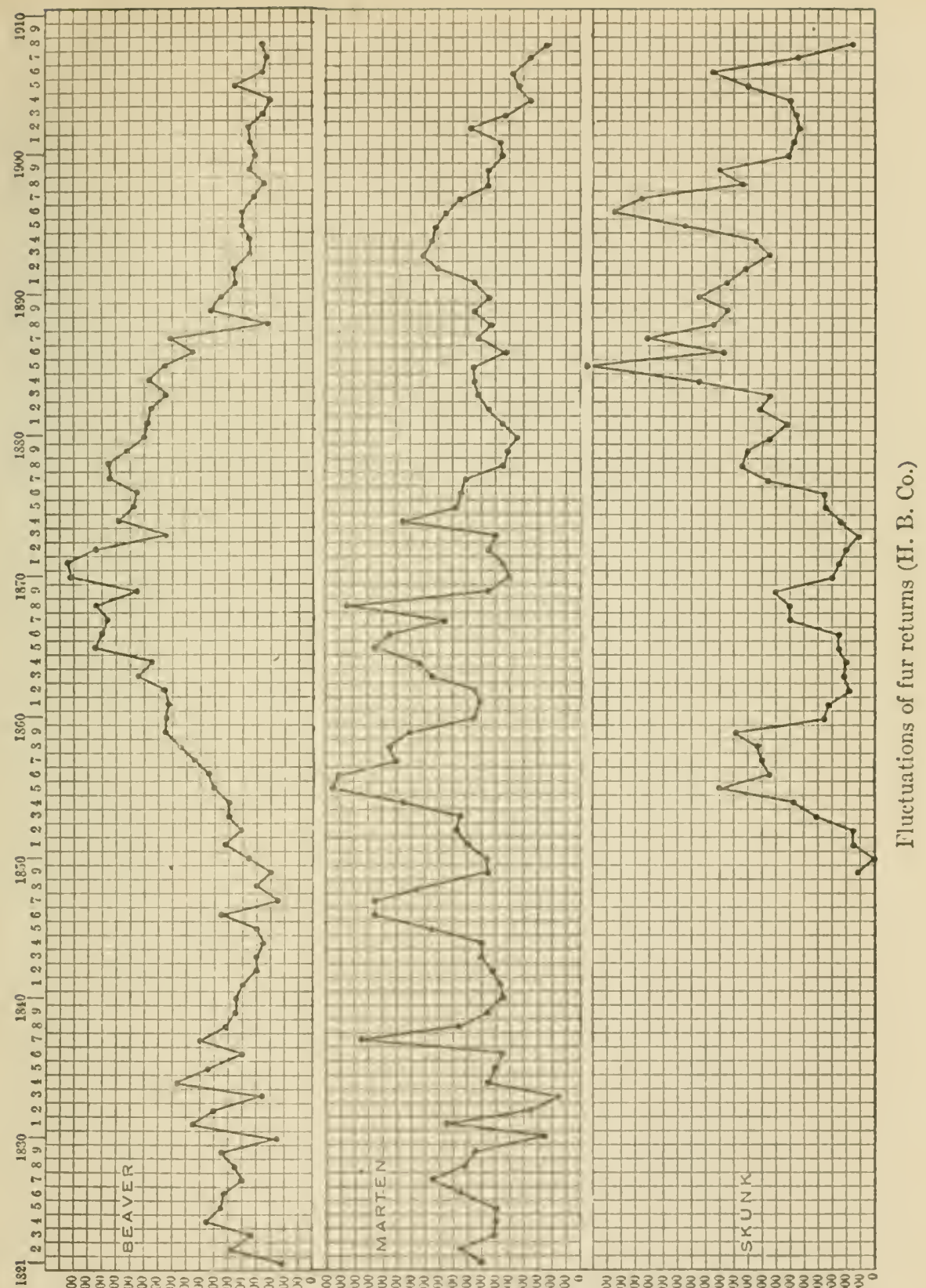

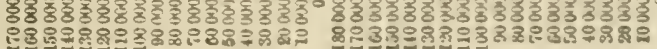




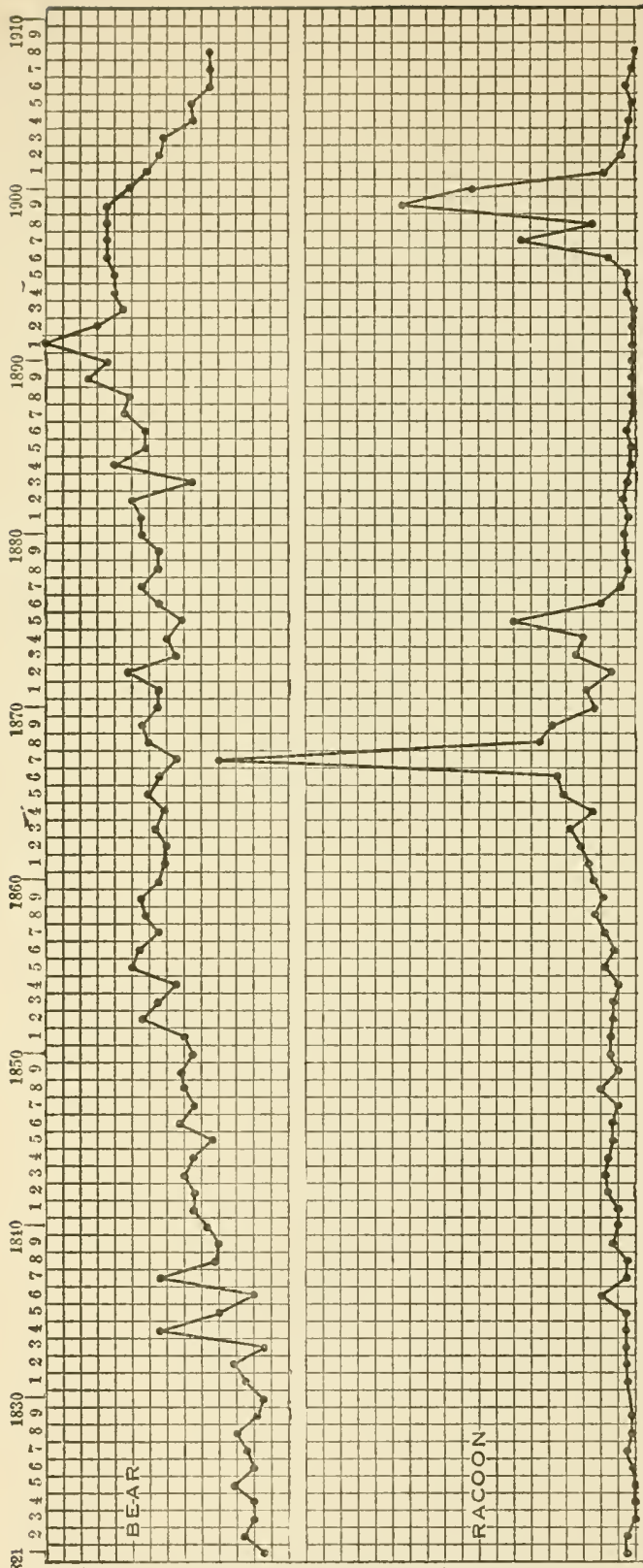

8. 严

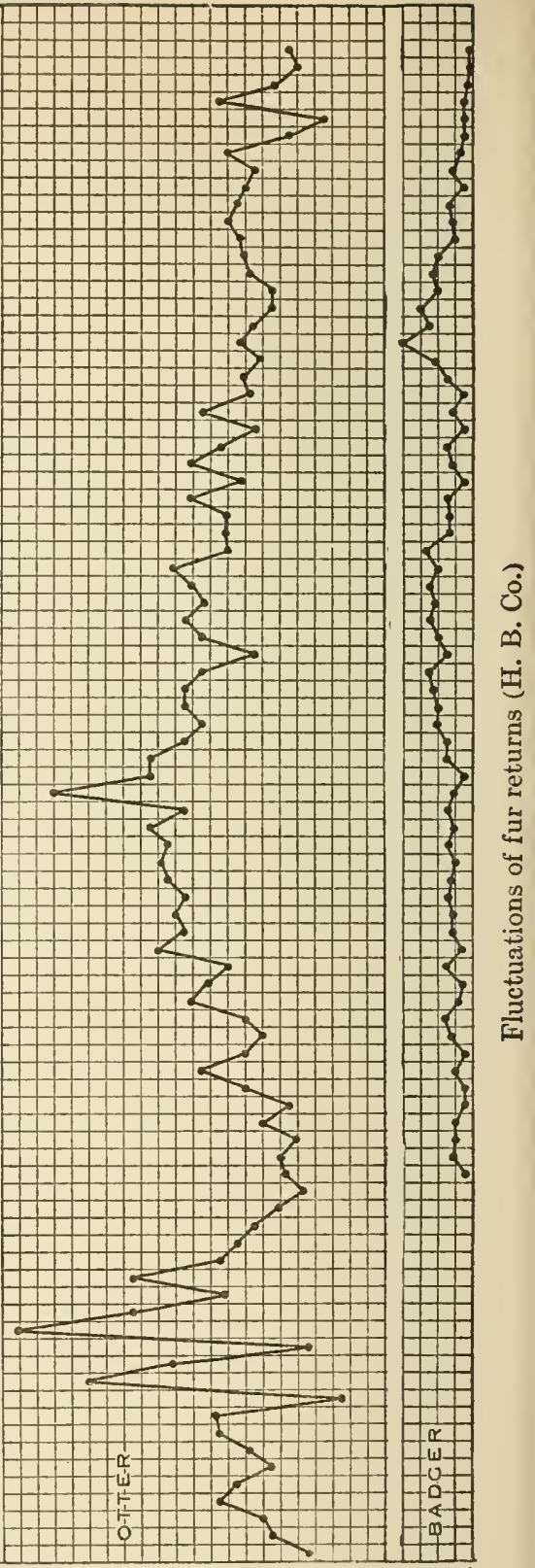

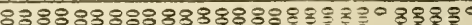

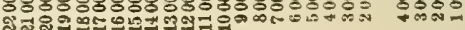



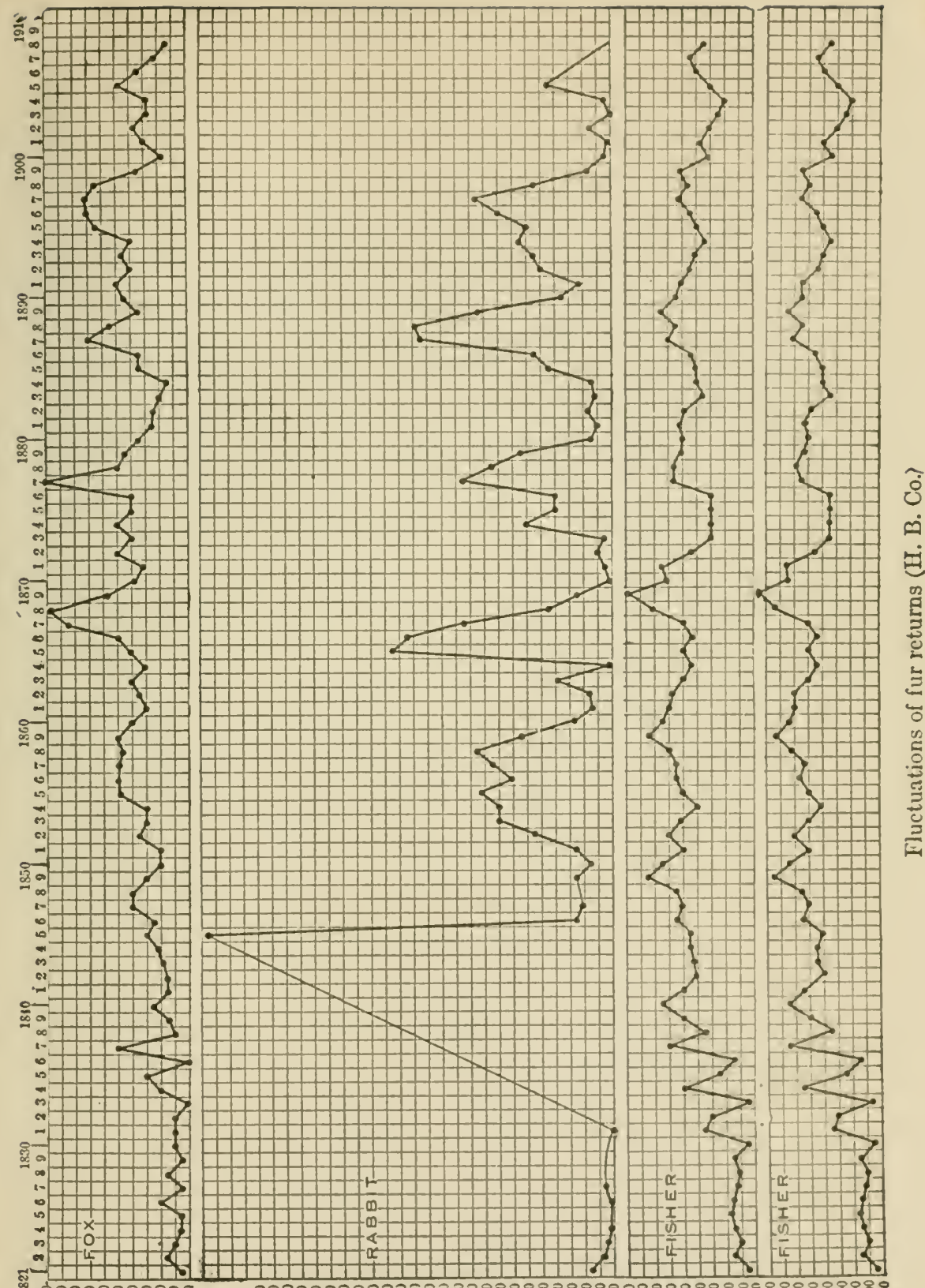

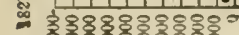

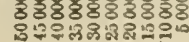

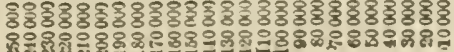



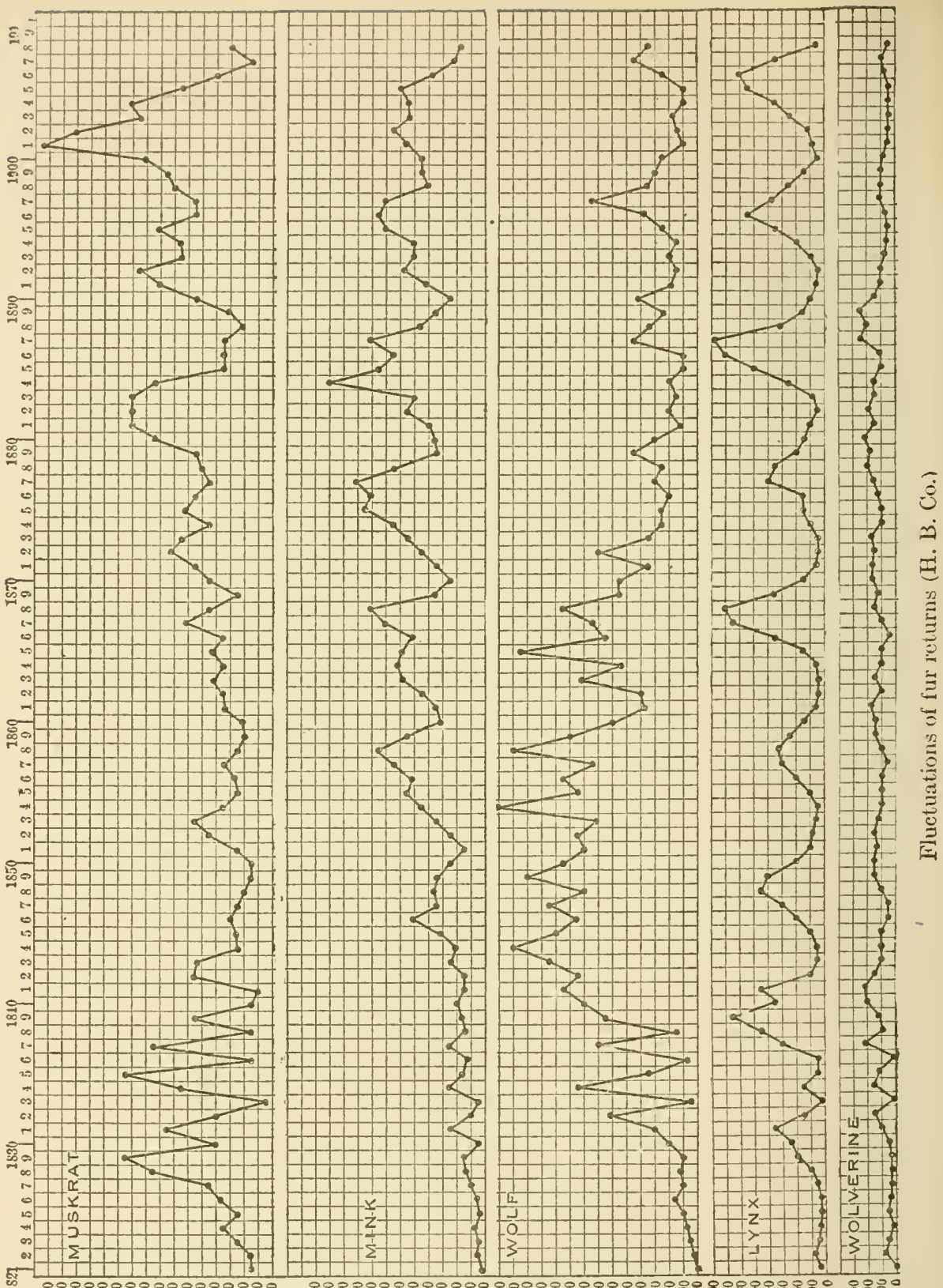

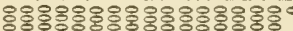

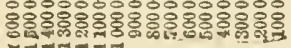

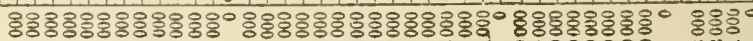




\section{CHAPTER XV}

\section{EBB AND FLOIV OF ANIMAL LIFE}

Tirroughout this voyage we were struck by the rarity of some sorts of animals and the continual remarks that three, five, or six years ago these same sorts were extremely abundant; and in some few eases the conditions were reversed.

For example, during a weck spent at Fort Smith, Preble had out a line of 50 mouse-traps every night and caught only one Shrew and one Meadowmouse in the week. Four years before he had trapped on exactly the same ground, catching 30 or 40 Meadowmice every night.

Again, in 1904 it was possible to see 100 Muskrats any fine evening. In 1907, though continually on the lookout, I saw less than a score in six months. Redsquirrels varied in the same way.

Of course, the Rabbits themselves were the extreme case, millions in 1904, none at all in 1907. The present, then, was a year of low ebb. The first task was to determine whether this related to all mammalian life. Apparently not, because Deermice, Lynxes, Beaver, and Caribou were abundant. Yet these are not their maximum years; the accounts show them to have been so much more numerous last year.

There is only one continuous statistical record of the abundance of animals, that is the returns of the 
fur trade. These have been kept for over 200 years, and if we begin after the whole continent was covered by fur-traders, they are an accurate gauge of the abundance of each species. Obviously, this must be so, for the whole country is trapped over every year, all the furs are marketed, most of them through the Hudson's Bay Company, and whatever falls into other hands

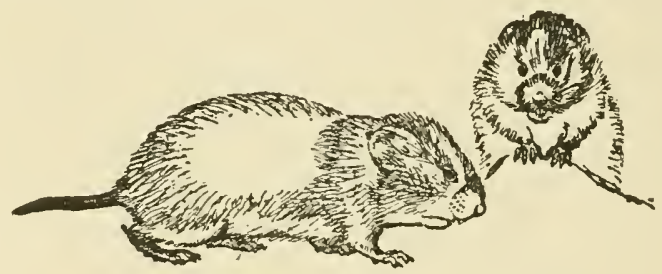

Drummond Vole or Fieldmouse

is about the same percentage each year, therefore the H. B. Co. returns are an accurate gauge of the relative rise and fall of the population.

Through the courtesy of its officials I have secured the Company's returns for the 85 years-1821-1905 inclusive. I take 1821 as the starting-point, as that was the first year when the whole region was covered by the Hudson's Bay Company to the exclusion of all important rivals.

First, I have given these accounts graphic tabulation, and at once many interesting facts are presented to the eye. The Rabbit line prior to 1845 is not reliable. Its subsequent close coincidence with that of Lynx, Marten, Skunk, and Fox is evidently cause and effect. The Mink coincides fairly well with Skunk and Marten. 
The Muskrat's variation probably has relation chiefly to the amount of water, which, as is well known, is cyclic in the north-west.

The general resemblance of Beaver and Otter lines may not mean anything. If, as said, the Otter occasionally preys on the Beaver, these lines should in some degree correspond.

The Wolf line does not manifest any special relationship and secms to be in a class by itself. The great destruction from 1840 to 1870 was probably due to strychnine, newly introduced about then.

The Bear, Badger, and Wolverine go along with little

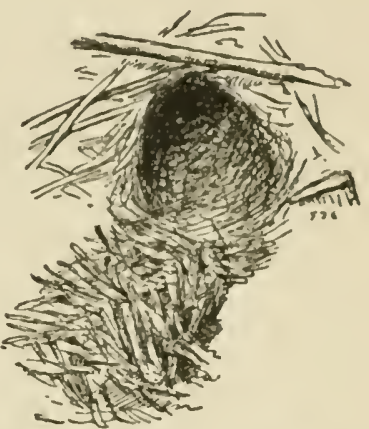

Microtus pocket hole. Edmonton, May 10, 1907

variation. Probably the Coon does the same; the enormous rise in 1567 from an average of 3,500 per annum to 24,000 was most likely a result of accidental accumulation and not representative of any special abundance. Finally, each and every line manifests extraordinary variability in the ' 30 's. It is not to be supposed that the population fluctuated so enormously from one year to another, but rather that the facilities for export were irregular.

The case is further complicated by the fact that some of the totals represent part of this year and part of last; nevertheless, upon the whole, the following general principles are deducible:

(a) The high points for each species are with fair regularity 10 years apart. 
(b) In the different species these are not exactly coincident.

(c) To explain the variations we must seek not the reason for the increase-that is normal-but for the destructive agency that ended the increase.

This is different in three different groups.

First. The group whose food and enemies fluctuate but little. The only examples of this on our list are the Muskrat and Beaver, more especially the Muskrat. Its destruction seems to be due to a sudden great rise of the water after the ice has formed, so that the Rats are drowned; or to a dry season followed by severe frost, freezing most ponds to the bottom, so that the Rats are imprisoned and starve to death, or are forced out to cross the country in winter, and so are brought within the power of innumerable enem es.

How tremendously this operates may be judged by these facts. In 1900 along the Mackenzie I was assured one could shoot 20 Muskrats in an hour after sundown. Next winter the flood followed the frost and the Rats seemed to have been wiped out. In 1907 I spent 6 months outdoors in the region and saw only 17 Muskrats the whole time; in 1901 the H. B. Co. exported over $1 \frac{1}{2}$ millions; in $1907,407,472$. The fact that they totalled as high was due, no doubt, to their abundance in eastern regions not affected by the disaster.

Second. The group that increases till epidemic disease attacks their excessively multiplied hordes. The Snowshoe-Rabbit is the only well-known case today, but there is reason for the belief that once the Beaver were subjected to a similar process. Concern- 
ing the Mice and Lemmings, I have not complete data, but they are believed to multiply and suffer in the same way.

Third. 'The purely carnivorous, whose existence is dependent on the Rabbits. This includes chiefly the Lynx and Fox, but in less degree all the small carnivores.

In some cases such as the Marten, over-feeding seems as inimical to multiplication as under-feeding, and it will be seen that each year of great increase for this species coincided with a medium year for Rabbits.

But the fundamental and phenomenal ease is that of the Rabbits themselves. And in solving this we are confronted by the generally attested facts that when on the increase they have two or three broods each season and $S$ to 10 in a brood; when they are decreasing they have but one brood and only 2 or 3 in that. This points to some obseure agency at work; whether it refers simply to the physical vigour of the fact, or to some uncomprehended magnetic or heliological cycle, is utterly unknown.

The practical consideration for the collecting naturalist is this: Beaver, Muskrat, Otter, Fisher, Raccoon, Badger, Wolverine, Wolf, Marten, Fox reached the low ebb in 1904-5. All are on the up-grade; presumably the same applies to the small rodents. Their decacycle will be complete in 1914-15, so that 1910-11 should be the years selected by the next collecting naturalist who would visit the north.

For those who will enter before that there is a reasonable prospect of all these species in fair numbers, 
except perhaps the Lynx and the Caribou. Evidently the former must be near minimum now (1909) and the latter would be scarce, if it is subject to the rule of the decacycle, though it is not at all proven that such is the case. 


\section{CHAPTER XVI}

\section{THE PELICAN TRIP}

We were still held back by the dilatory ways of our Indian friends, so to lose no time Preble and I determined to investigate a Pelican rookery.

Most persons associate the name Pelican with tropic lands and fish, but ornithologists have long known that in the interior of the continent the great white Pelican ranges nearly or quite to the Arctic circle. The northmost colony on record was found on an island of Great Slave Lake (see Preble, "N. A. Fauna," 27), but this is a very small one. The northmost large colony, and the one made famous by travellers from Alexander Mackenzie downward, is on the great island that splits the Smith Rapids above Fort Smith. Here, with a raging flood about their rocky citadel, they are safe from all spoilers that travel on the earth; only a few birds of the air need they fear, and these they have strength to repel.

On June 22 we set out to explore this. Preble, Billy, and myself, with our canoe on a wagon, drove 6 miles back on the landing trail and launched the canoe on the still water above Mountain Portage. Pelican Island must be approached exactly right, in the comparatively slow water above the rocky island, for 20 feet away on each side is an irresistible current 
leading into a sure-death cataract. But Billy was a river pilot and we made the point in safety.

Drifted like snow through the distant woods were the brooding birds, but they arose before we were near and sailed splendidly overhead in a sweeping, wide-fronted rank. As nearly as I could number them, there were 120 , but evidently some were elsewhere, as this would not allow a pair to each nest.

We landed safely and found the nests scattered among the trees and fallen timbers. One or two mother birds ran off on foot, but took wing as soon as clear of the woods-none remained.

The nests numbered 77, and there was evidence of others long abandoned. There were $163 \mathrm{eggs}$, not counting 5 rotten ones, lying outside; nearly all had 2 eggs in the nest; 3 had $4 ; 5$ had $3 ; 4$ had 1 . One or two shells were found in the woods, evidently sucked by Gulls or Ravens.

All in the nests were near hatching. One little one had his beak out and was uttering a hoarse chirping; a dozen blue-bottle flies around the hole in the shell were laying their eggs in it and on his beak. This led us to examine all the nests that the flies were buzzing around, and in each case (six) we found the same state of affairs, a young one with his beak out and the flies "blowing" around it. All of these were together in one corner, where were a dozen nests, probably another colony of earlier arrival.

We took about a dozen photos of the place (large and small). Then I set my camera with the long tube to get the old ones, and we went to lunch at the other 
end of the island. It was densely wooded and about an acre in extent, so we thought we should be forgotten. The old ones circled high overhead but at last dropped, I thought, back to the nests. After an hour and a half I returned to the ambush; not a Pelican was there. Two Ravens flew high over, but the Pelicans were far away, and all as when we went away, leaving the young to struggle or get a death-chill as they might. So much for the pious Peliean, the emblem of reckless devotion-a common, dirty little cock Sparrow would put them all to shame.

We brought away only the 5 rotten eggs. About half of the old Pelicans had horns on the bill.

On the island we saw a flock of White-winged Crossbills and heard a Song-sparrow. Gulls were seen about. The white spruce cones littered the ground and were full of seed, showing that no Redsquirrel was on the island.

We left successfully by dashing out exactly as we came, between the two dangerous currents, and got well away.

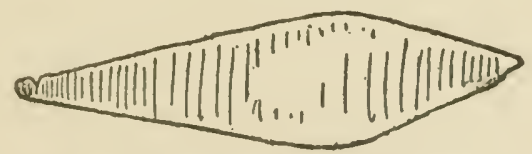

Spruce net-float $20 \times 5 \times \frac{1}{1}$ inches 


\section{CHAPTER XVII}

\section{THE THIRD BUFFALO HUNT}

The Indians are simply large children, and further, no matter how reasonable your proposition, they take a long time to consider it and are subject to all kinds of mental revulsion. So we were lucky to get away from Fort Smith on July 4 with young François Bezkya as guide. He was a full-blooded Chipewyan Indian, so full that he had knowledge of no other tongue, and Billy had to be go-between.

Bezkya, the son of my old patient, came well recommended as a good man and a moose-hunter. A "good man" means a strong, steady worker, as canoeman or portager. He may be morally the vilest outcast unhung; that in no wise modifies the phrase "he is a good man." But more: the present was a moose-hunter; this is a wonderfully pregnant phrase. Moose-hunting by fair stalking is the pinnacle of woodcraft. The Crees alone, as a tribe, are supposed to be masters of the art; but many of the Chipewyans are highly successful. One must be a consummate trailer, a good shot, have tireless limbs and wind and a complete knowledge of the animal's habits and ways of moving and thinking. One must watch the wind, without ceasing, for no hunter has the slightest chance of success if once the Moose should scent him. This 
last is fundamental, a three-times sacred principle. Not long ago one of these Chipewyans went to confessional. Although a year had passed since last he got cleaned up, he could think of nothing to confess. Oh! spotless soul! However, under pressure of the priest, he at length remembered a black transgression. The fall before, while hunting, he went to the wind-

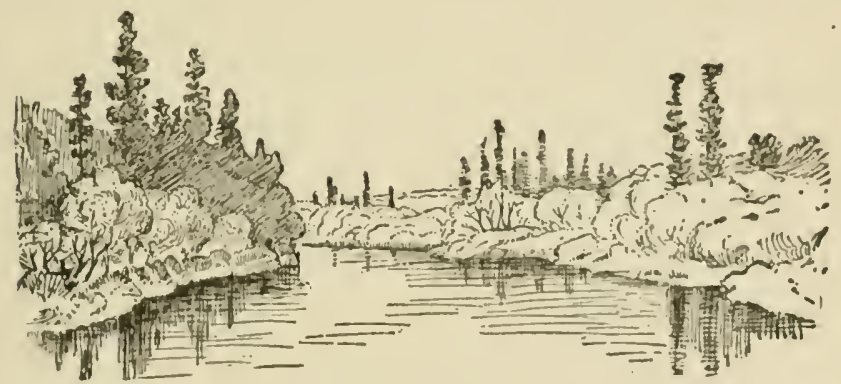

Little Buffalo River looking north. July 8, 1907

ward of a thicket that seemed likely to hold his Moose, because on the lee, the proper side, the footing happened to be very bad, and so he lost his Moose. Yes! there was indeed a dark shadow on his recent past.

A man may be a good hunter, $i$. e., an all-round trapper and woodman, but not a moose-hunter. At Fort Smith are two or three scores of hunters, and yet I am told there are only three moose-hunters. The phrase is not usually qualified; he $i s$, or is not, a moose-hunter. Just as a man is, or is not, an Oxford M.A. The force, then, of the phrase appears, and we were content to learn that young Bezkya, besides knowing the Buffalo country, was also a good man and a moose-hunter. 
We set out in two canoes, Bezkya and Jarvis in the small one, Billy, Selig, Preble, and I in the large one, leaving the other police boys to make Fort Resolution in the H. B. steamer.

Being the 4th of July, the usual torrential rains set in. During the worst of it we put in at Salt River village. It was amusing to see the rubbish about the

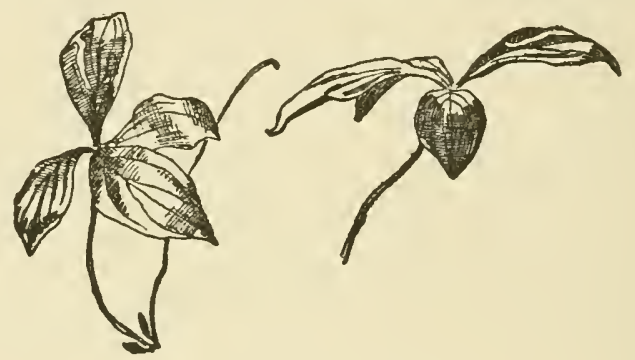

Cornus canadensis

doors of these temporarily deserted cabins. The midden-heaps of the Cave-men are our principal sources of information about those by-gone races; the future ethnologist who discovers Salt River midden-heaps will find all the usual skulls, bones, jaws, teeth, flints, etc., mixed with moccasin beads from Venice, brass cartridges from New England, broken mirrors from France, Eley cap-boxes from London, copper rings, silver pins, lead bullets, and pewter spoons, and interpersed with them bits of telephone wires and the fragments of gramophone discs. I wonder what they will make of the last!

Eight miles farther we camped in the rain, reaching the Buffalo Portage next morning at 10, and had everything over its 5 miles by 7 o'clock at night. 
It is easily set down on paper, but the uninitiated can scarcely realise the fearful toil of portaging. If you are an office man, suppose you take an angular box weighing 20 or 30 pounds; if a farmer, double the weight, poise it on your shoulders or otherwise, as you please, and carry it half a mile on a level pavement in cool, bright weather, and I am mistaken if you do not find yourself suffering horribly before the end of a quarter-mile; the last part of the trip will have been made in something like mortal agony. Remember, then, that each of these portagers was earrying 150 to 250 pounds

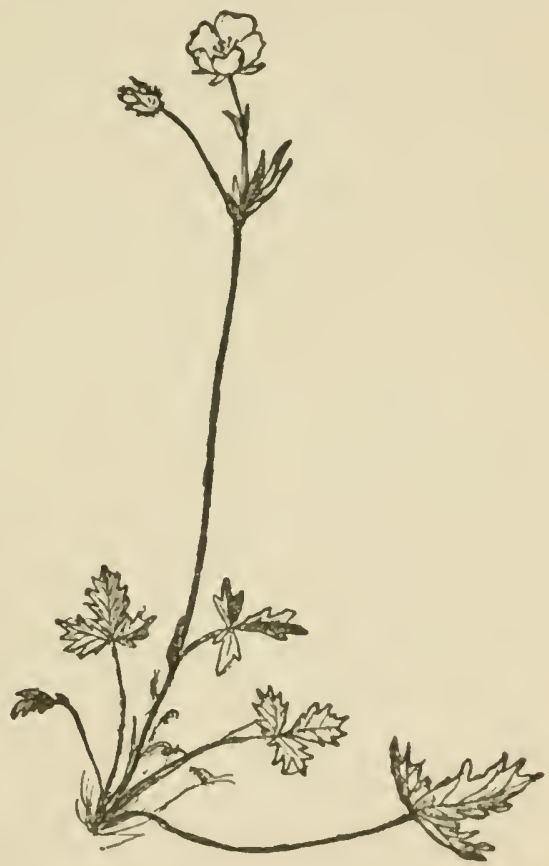

Ranunculus of broken stuff, not half a mile, but sereral miles, not on level pavement, but orer broken rocks, up banks, through quagmires and brush -in short, across ground that would be difficult walking without any burden, and not in cool, clear weather, but through stifling swamps with no free hand to ease the myriad punctures of his body, face, and limbs whenever un- 
sufficiently protected from the stingers that roam in clouds. It is the hardest work I ever saw performed by human beings; the burdens are heavier than some men will allow their horses to carry.

Yet all this frightful labour was cheerfully gone through by white men, half-breeds, and Indians alike. They accept it as a part of their daily routine. This
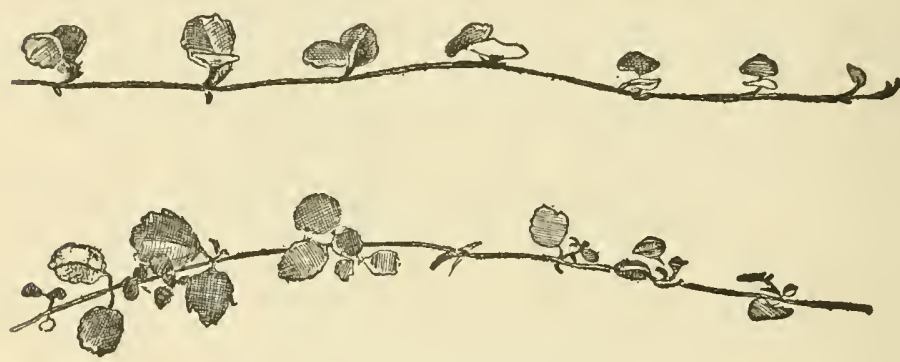

Linnæa americana

fact alone is enough to guarantee the industrial future of the red-man when the hunter life is no longer possible.

Next day we embarked on the Little Buffalo River, beginning what should have been and would have been a trip of memorable joys but for the awful, awful, awful-see Chapter IX.

The Little Buffalo is the most beautiful river in the whole world except, perhaps, its affluent, the Nyarling.

This statement sounds like the exaggeration of mere impulsive utterance. Perhaps it is; but I am writing now after thinking the matter over for two and a half years, during which time I have seen a thousand 
others, including the upper Thames, the Afton, the Seine, the Arno, the 'Tiber, the Iscr, the Sprece, and the Rhine.

A hundred miles long is this uncharted stream; fifty fret its breadth of limpid tide; eight feet deep, crystal clear, ealm, slow, and deep to the margin. A steamer could ply on its placid, unobstructed flood, a child could navigate it anywhere. The heavenly beauty of

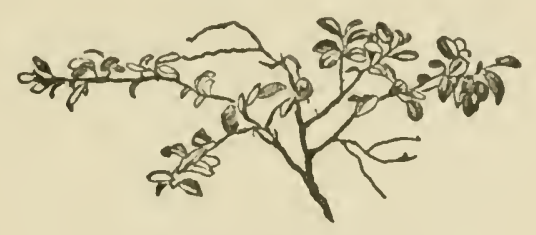

Cranberry fruit and flowers

the shores, with virgin forest of fresh, green spmuces towering a hundred feet on every side, or varied in open places with long rows and thick-set hedges of the gorgeous, wild, red, Athabaska rose, made a stream that most canoemen, woodmen, and naturalists would think without a fault or flaw, and with every river beauty in its highest possible degrec. Not trees and flood alone had strenuous power to win our souls; at every point and bank, in every bend, were living creatures of the north, Beaver and Bear, not often seen but abundant; Moose tracks showed from time to time and birds were here in thousands. Rare winter birds, as we had long been taught to think them in our southern homes; here we found them in their native land and heard not a few sweet melodies, of which in faraway Ontario, New Jersey, and Maryland we had been 
favoured only with promising scraps when wintry clouds were broken by the sun. Nor were the old familiar ones away-Flicker, Sapsucker, Hairy Woodpecker, Kingfisher, Least Flycatcher, Alder Flycatcher, Robin, Crow, and Horned Owl were here to mingle their noises with the stranger melodies

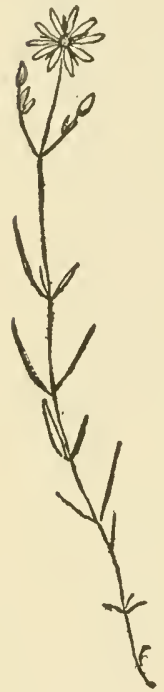

Stellaria and calls of Lincoln Sparrow, Fox Sparrow, Olive-sided Flycatcher, Snipe, Rusty Blackbird, and Bohemian Waxwing.

Never elsewhere have I seen Horned Owls so plentiful. I did not know that there were so many Bear and Beaver left; I never was so much impressed by the inspiring raucous clamour of the Cranes, the continual spatter of Ducks, the cries of Gulls and Yellowlegs. Hour after hour we paddled down that stately river adding our $3 \frac{1}{2}$ miles to its 1 mile speed; each turn brought to view some new and lovelier aspect of bird and forest life. I never knew a land of balmier air; I never felt the piney breeze more sweet; nowhere but in the higher mountains is there such a tonic sense abroad; the bright woods and river reaches were eloquent of a clime whose maladies are mostly foreign-born. But alas! I had to view it all swaddled, body, hands, and head, like a bee-man handling his swarms. Songs were muffled, scenes were dimmed by the thick, protecting, suffocating veil without which men can scarcely live.

Ten billion dollars would be all too small reward, 


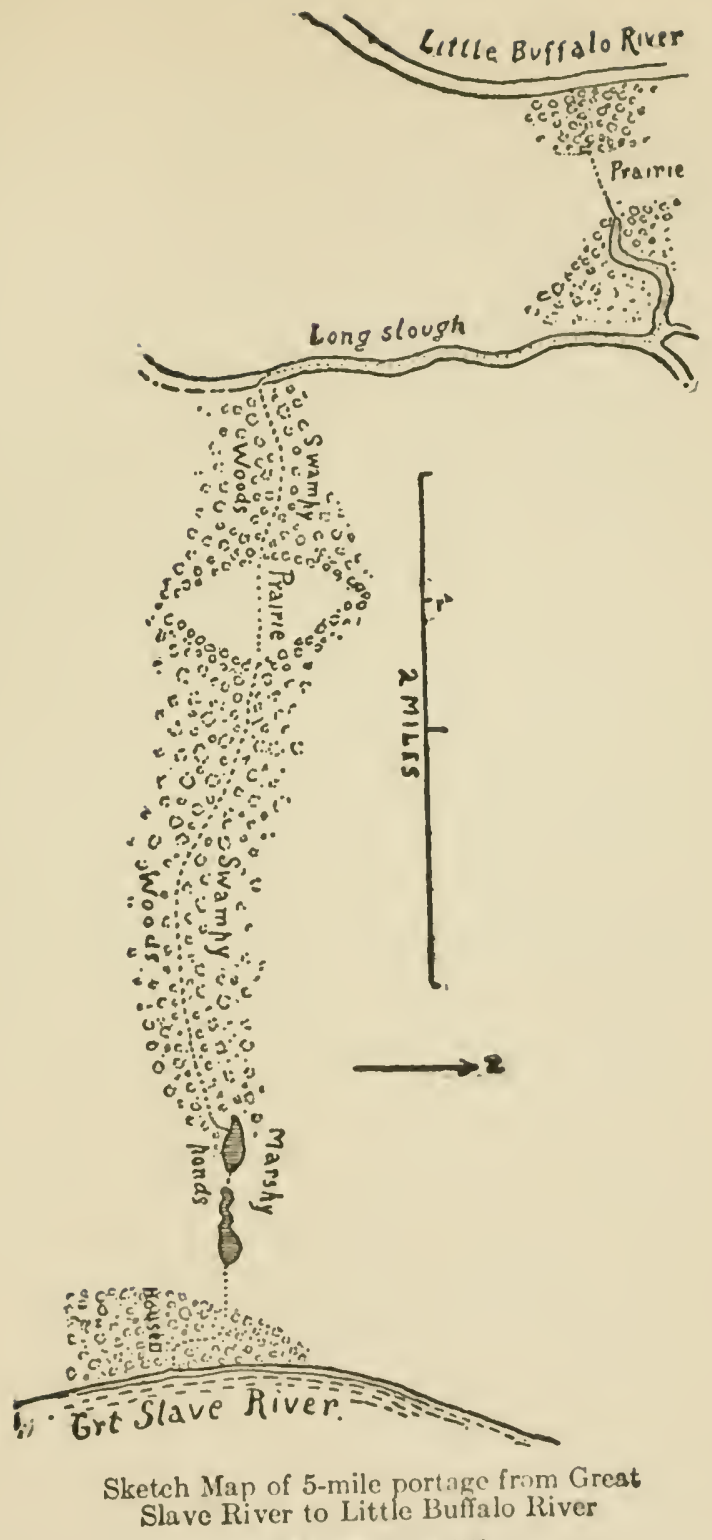

By E T. Solon, Juna, 1907 
a trifle totally inadequate to compensate, mere nominal recognition of the man who shall invent and realise a scheme to save this earthly paradise from this its damning pest and malediction.

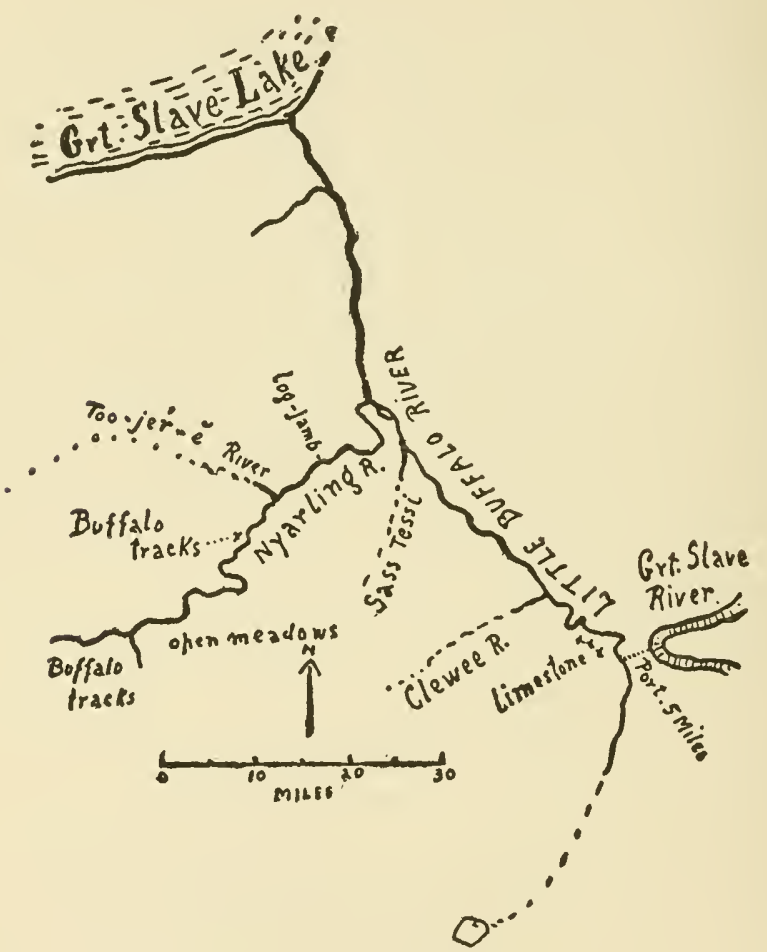

Buffalo and Nyarling Rivers

By E. T. Seton, July, 1907 


\section{CHAPTER XVIII}

\section{DOWN 'TO FUNDAMENTAIS}

At 8.30 A. M., 10 miles from the portage, we eame to the Clew-ee, or White Fish River; at $6.30 \mathrm{P}$. x. made the Sass Tessi, or Bear River, and here camped, having covered fully 40 miles.

Now for the first time we were all together, with leisure to question our guide and plan in detail. But all our mirth and hopes were rudely checked by Corporal Selig, who had entire charge of the commissary, announcing that there were only two day's' rations left.

In the dead calm that followed this bomb-shell we all did some thinking; then a rapid fire of questions demonstrated the danger of having a guide who does not speak our language.

It seems that when asked how many day's' rations we should take on this Buffalo hunt he got the idea how many days to the Buffalo. He said five, meaning five days each way and as much time as we wished there. We were still two days from our goal. Now what r should we do? Scurry back to the fort or go ahead and trust to luck? Every man present voted "go ahead on half rations."

We had good, healthy appetites; half rations was veritable hardship; but our hollow insides made hearty laughing. Preble disappeared as soon as we camped, 
and now at the right time he returned and silently threw at the cook's feet a big 6-pound Pike. It was just right, exactly as it happens in the most satisfactory books and plays. It seems that he always carried a spoon-hook, and went at once to what he rightly judged the best place, a pool at the junction of the two rivers. The first time he threw he captured the big fellow. Later he captured three smaller ones in the same place, but evidently there were no more.

That night we had a glorious feast; every one had as much as he could eat, chiefly fish. Next morning we went on $4 \frac{1}{2}$ miles farther, then came to the mouth of the Nyarling Tessi, or Underground River, that joins the Buffalo from the west. This was our stream; this was the highway to the Buffalo country. It was a miniature of the river we were leaving, but a little quicker in current. In about 2 miles we came to a rapid, but were able to paddle up. About 5 miles farther was an immense and ancient log-jamb that filled the stream from bank to bank for 190 yards. What will be the ultimate history of this jamb? It is added to each year, the floods have no power to move it, logs in water practically never rot, there is no prospect of it being removed by natural agencies. I suspect that at its head the river comes out of a succession of such things, whence its name Underground River.

Around this jamb is an easy portage. We were far now from the haunts of any but Indians on the winter hunt, so were surprised to see on this portage trail the deep imprints of a white man's boot. These were made apparently within a week, by whom I never 
learned. On the bank not far away we saw a Lynx pursued overhead by two scolding Redsquirrels.

Lunch consisted of what remained of the Pike, but that afternoon Bezkya saw two Brown Cranes on a meadow, and manœuvring till they were in line killed both with one shot of his rifle at over 100 yards, the best shot I ever knew an Indian to make. Still, two

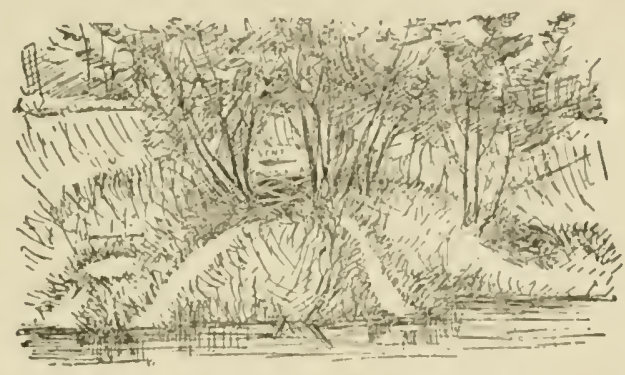

Double lodge in bank 12 yards long, $4 \frac{1}{2}$ feet high. July 7, 1907

Cranes totalling 16 pounds gross is not enough meat to last five men a week, so we turned to our Moose-hunter. "Yes, he could get a Moose." He went on in the small canoe with Billy; we were to follow, and if we passed his canoe leave a note. Seven miles above the log-jamb, the river forked south and west; here a note from the guide sent us up the South Fork; later we passed his canoe on the bank and knew that he had landed and was surely on his way "to market." What a comfortable feeling it was to remember that Bezky:a was a moose-hunter! We left word and travelled till 7, having come 11 miles up from the river's mouth. Our supper that night was Crane, a little piece of bread each, some soup, and some tea. 
At 10 the hunters came back empty-handed. Yes, they found a fresh Moose track, but the creature was so pestered by clouds of — that he travelled continually as fast as he could against the wind. They followed all day but could not overtake him. They saw a Beaver but failed to get it. No other game was found.

Things were getting serious now, since all our food consisted of 1 Crane, 1 tin of brawn, 1 pound of bread, 2 pounds of pork, with some tea, coffee, and sugar, not more than one square meal for the crowd, and we were 5 men far from supplies, unless our hunting proved successful, and going farther every day.

Next morning (July 9) each man had coffee, one lady's finger of bread, and a single small slice of bacon. Hitherto from choice I had not eaten bacon in this country, although it was a regular staple served at each meal. But now, with proper human perversity, I developed an extraordinary appetite for bacon. It seemed quite the most delicious gift of God to man. Given bacon, and I was ready to forgo all other foods. Nevertheless, we had divided the last of it. I cut my slice in two, revelled in half, then secretly wrapped the other piece in paper and hid it in the watch-pocket of my vest, thinking "the time is in sight when the whole crowd will be thankful to have that scrap of bacon among them." (As a matter of fact, they never got it, for five days later we found a starving dog and he was so utterly miserable that he conjured that scrap from the pocket next my heart.)

We were face to face with something like starvation 
now; the game seemed to shun us and our store of victuals was done. Yet no one talked of giving up or going back. We set out to reach the Buffalo country, and reach it we would.

That morning we got 7 little Teal, so our lunch was sure, but straight 'Teal without accompaniments is not rery satisfying; we all went very hungry. And with one mind we all thought and talked about the good dinners or specially fine food we once had had. Selig's dream of bliss was a porterhouse steak with a glass of foaming beer; Jarvis thought champagne and roast turkey spelt heaven just then; I thought of my home breakfasts and the Beaux-Arts at New York; but Billy said he would he perfectly happy if he could have one whole bannock all to himself. Preble said nothing. 


\section{CHAPTER XIX}

\section{WHITE MAN AND RED. MEAT, BUT NOTHING MORE}

THERE was plenty of hollow hilarity but no word of turning back. But hold! yes, there was. There was one visage that darkened more each day, and finally the gloomy thoughts broke forth in words from the lips of-our Indian guide. His recent sullen silence was now changed to open and rebellious upbraiding. "He didn't come here to starve. He could do that at home. He was induced to come by a promise of plenty of flour." All of which was perfectly true. But, he went on, "We were still $1 \frac{1}{2}$ days from the Buffalo, and we were near the head of navigation; it was a case of tramp through the swamp with our beds and guns, living on the country as we went, and if we didn't have luck the Coyotes and Ravens would."

Before we had time to discuss this prospect, a deciding step was announced by Jarvis. He was under positive orders to catch the steamer Wrigley at Fort Resolution on the evening of July 10. It was now mid-day of July 9 , and only by leaving at once and travelling all night could he cover the intervening 60 miles.

So then and there we divided the remnants of food evenly, for "Bezkya was a moose-hunter." 
Then Major Jarvis and Corporal Selig boarded the smaller canoe. We shook hands warmly, and I at least had a lump in my throat; they were such good fellows in camp, and to part this way when we especially felt bound to stick together, going each of us on a journey of privation and peril, seemed especially hard; and we were so hungry. But we were living our lives. They rounded the bend, we waved goodbye, and I have never seen them since.

Hitherto I was a guest; now I was in sole command, and called a council of war. Billy was stanch and ready to go anywhere at any cost. So was Preble. Bezkya was sulky and rebellious. Physically, I had been at the point of a total breakdown when I left home; the outdoor life had been slowly restoring me, but the last few days had weakened me sadly and I was not fit for a long expedition on foot. But of one thing I was sure, we must halt till we got food. A high wind was blowing and promised some respite to the Moose from the little enemy that sings except when he stings, so I invited Bezkya to gird up his loins and make another try for Moose.

Nothing loath, he set off with Billy. I marked them well as they went, one lithe, sinewy, active, animaleyed; the other solid and sturdy, following doggedly, keeping up by sheer blundering strength. I could not but admire them, each in his kind.

Two hours later I heard two shots, and toward evening the boys came back slowly, tired but happy, burdened with the meat, for Berkya was a moosehunter. 
Many shekels and gladly would I have given to have been on that moose hunt. Had I seen it I could have told it. These men, that do it so well, never can tell it. Yet in the days that followed I picked up a few significant phrases that gave glimpses of its action.

Through the crooked land of endless swamp this son of the woods had set out "straightaway west." A big track appeared crossing a pool, seeming fresh. "No! he go by yesterday; water in track not muddy." Another track was found. "Yes, pretty good; see bite alder. Alder turn red in two hours; only half red." Follow long. "Look out, Billy; no go there; wrong wind. Yes, he pass one hour; see bit willow still white. Stop; he pass half-hour; see grass still bend. He lie down soon. How know? Oh, me know. Stand here, Billy. He sleep in thick willow there."

Then the slow crawl in absolute stillness, the long wait, the betrayal of the huge beast by the ear that wagged furiously to shake off the winged bloodsuckers. The shot, the rush, the bloody trail, the pause in the opening to sense the foe, the shots from both hunters, and the death.

Next day we set out in the canoe for the Moose, which lay conveniently on the river bank. After pushing through the alders and poling up the dwindling stream for a couple of hours we reached the place two miles up, by the stream. It was a big bull with no bell, horns only two-thirds grown but 46 inches across; the tips soft and springy; one could stick a knife through them anywhere outside of the basal half. 
Bezkya says they are good to eat in this stage; but we had about 700 pounds of good meat so did not try. The velyet on the horns is marked by a series of concentric eurved lines of white hair, across the lines of growth; these, I take it, correspond with times of check by ehill or hardship.

We loaded our eanoe with meat and pushed on toward the Buffalo country for two miles more up the river. Navigation now became very difficult on account of alders in the stream. Bezkya says that only a few hundred yards farther and the river comes from underground. This did not prove quite correct, for I went half a mile farther by land and found no change.

Here, however, we did find some Buffalo tracks; one went through our camp, and farther on were many, but all dated from the spring and were evidently six weeks old.

There were no recent tracks, which was discouraging, and the air of gloom over our camp grew heavier. The weather had been bad ever since we left Fort Smith, cloudy or showery. This morning for the first time the day dawned with a clear sky, but by noon it was cloudy and soon again raining. Our dict consisted of nothing but Moose meat and tea; we had neither sugar nor salt, and the craving for farinaceous food was strong and growing. We were what the natives call "flour hungry"; our three-times-a-day prospect of Moose, Moose, Moose was beeoming loathsome. Bezkya was openly rebellious once more, and even my two trusties were very, very glum. Still, the 
thought of giving up was horrible, so I made a proposition: "Bezkya, you go out scouting on foot and see if you can locate a band. I'll give you five dollars extra if you show me one Buffalo."

At length he agreed to go provided I would set out for Fort Resolution at once unless he found Buffalo near. This was leaving it all in his hands. While I was considering, Preble said: "I tell you this delay is playing the mischief with our Barren-Ground trip; we should have started for the north ten days ago," which was in truth enough to settle the matter.

I knew perfectly well beforehand what Bezkya's report would be.

At 6.30 he returned to say he found nothing but old tracks. There were no Buffalo nearer than two days' travel on foot, and he should like to return at once to Fort Resolution.

There was no further ground for debate; every one and everything now was against me. Again I had to swallow the nauseating draught of defeat and retreat.

"We start northward first thing in the morning," I said briefly, and our third Buffalo hunt was over. These, then, were the results so far as Buffalo were concerned: Old tracks as far down as last camp, plenty of old tracks here and westward, but the Buffalo, as before on so many occasions, were two days' travel to the westward.

During all this time I had lost no good opportunity of impressing on the men the sinfulness of leaving a camp-fire burning and of taking life unnecessarily; and now I learned of fruit from this seeding. That 
night Bezkya was in a better humour, for obvious reasons; he talked freely and told me how that day he came on a large Blackbear which at once took to a tree. The Indian had his rifle, but thought, "I can kill him, yet I can't stop to skin him or use his meat," so left him in perce.

This is really a remarkable incident, almost unique. I am glad to believe that I had something to do with causing such unusual forbcarance.

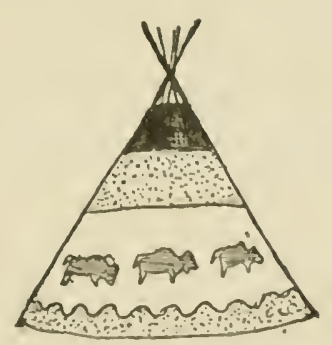

Blackfoot lodge, Calgary 


\section{CHAPTER XX}

\section{ON THE NYARLING}

ALL night it rained; in the morning it was dull, foggy, and showery. Everything was very depressing, especially in view of this second defeat. The steady diet of Moose and tea was debilitating; my legs trembled under me. I fear I should be a poor one to stand starvation, if so slight a brunt should play such havoc with my strength.

We set out early to retrace the course of the Nyarling, which in spite of associated annoyances and disappointments will ever shine forth in my memory as the "Beautiful River."

It is hard, indeed, for words to do it justice. The charm of a stream is always within three feet of the surface and ten feet of the bank. The broad Slave, then, by its size wins in majesty but must lose most all its charm; the Buffalo, being fifty feet wide, has some waste water; but the Nyarling, half the size, has its birthright compounded and intensified in manifold degree. The water is clear, two or three feet deep at the edge of the grassy banks, seven to ten feet in midchannel, without bars or obstructions except the two log-jambs noted, and these might easily be removed. The current is about one mile and a half an hour, so that canoes can readily pass up or down; the scenery 


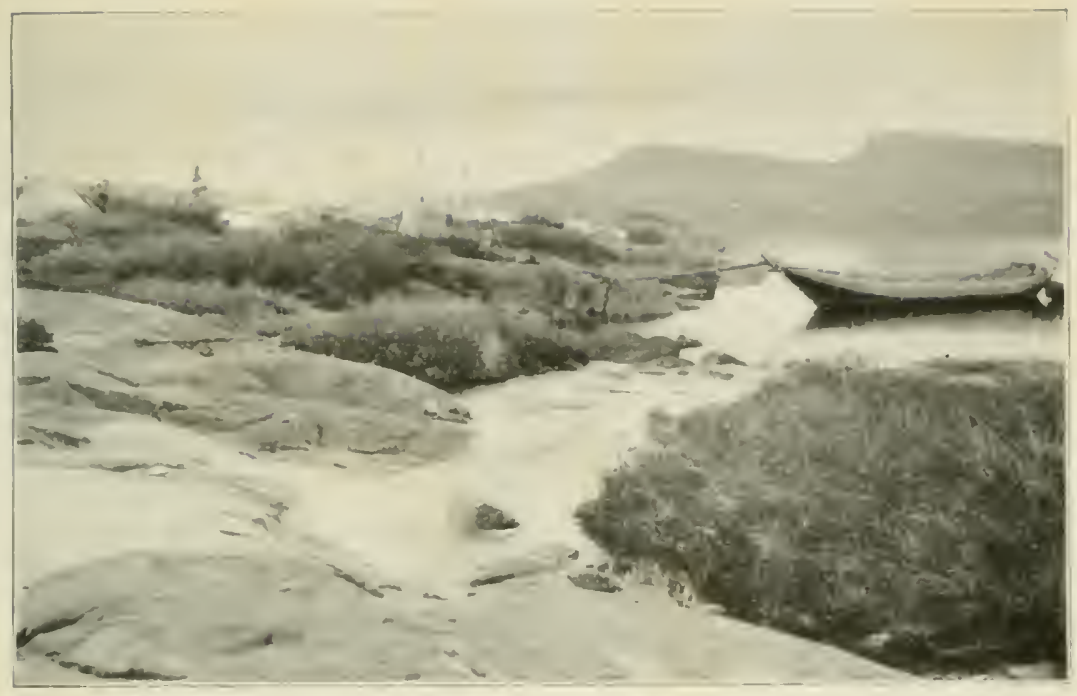

July camp on the Great Sliste Latke

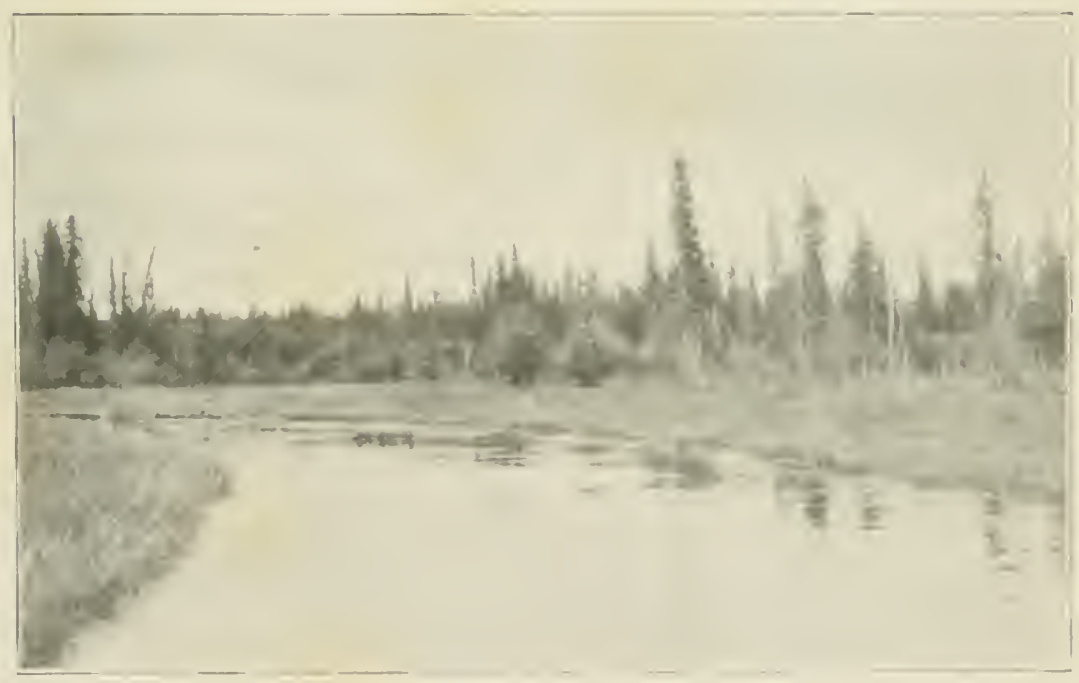

The Nyarling Tessi or Underground River 

varies continually and is always beautiful. Everything that I have said of the Little Buffalo applies to the Nyarling with fourfold foree, because of its more varied secnery and greater range of bird and other life. Sometimes, like the larger stream, it presents a long, straight vista of a quarter-mile through a solemn aisle in the forest of mighty spruce trees that tower a hundred feet in height, all black with gloom, green with heilth, and gray with moss.

Sometimes its channel winds in and out of open grassy meadows that are dotted with elumps of rounded trees, as in an English park. Now it narrows to a deep and simuous hed, through alders so rank and reaching that they meet overhead and form a shate of golden

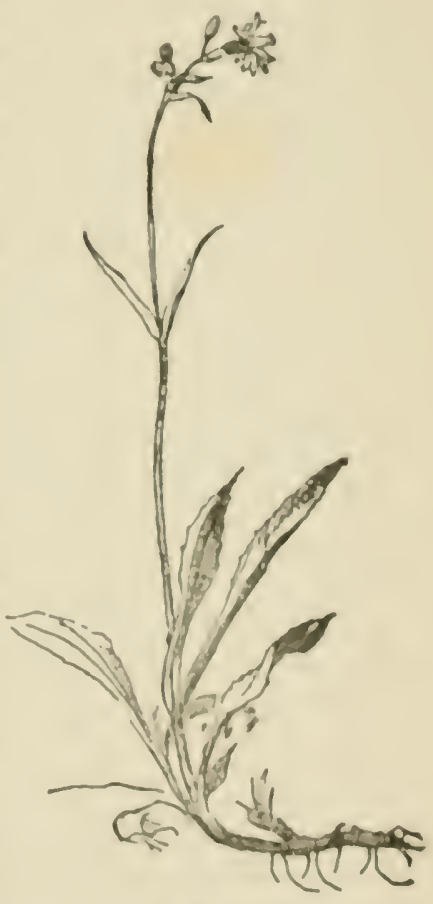

Sincrio green: and again it widens out into reedy lakes, the summer home of countlese Ducks, Geese, Tattlers Terns, Peetweets, Gulls, Rails, Blackbirds, and half a hundred of the leser tribes. Snmetimes the foreground is rounded masess of kimikinnik in snowy flower, or again a far-strung growth of the needle 
bloom, richest and reddest of its tribe-the Athabaska rose. At times it is skirted by tall poplar woods where the claw-marks on the trunks are witness of the many

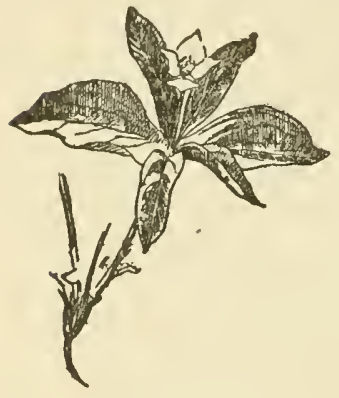

Cornel

Blackbears, or some tamarack swamp showing signs and proofs that hereabouts a family of Moose had fed to-day, or by a broad and broken trail that told of a Buffalo band passing weeks ago. And while we gazed at scribbled records, blots, and marks, the loud "slap plong" of

a Beaver showed from time to time that the thrifty ones had dived at our approach.

On the way up Jarvis had gone first in the small canoe; he saw 2 Bears, 3 Beaver, and 1 Lynx; I saw nothing but birds. On the way down, being alone, the luck came my way.

At the first camp, after he left, we heard a loud

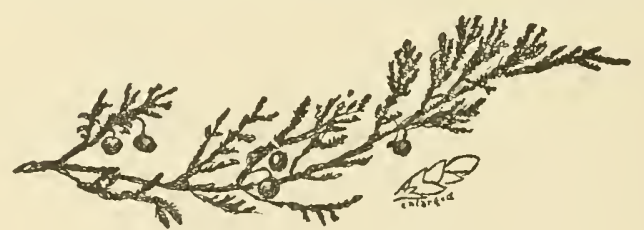

Ground Juniper, Juniperus sabina

"plong" in the water near the boat. Bezkya glided to the spot; I followed-here was a large Beaver swimming. The Indian fired, the Beaver plunged, and we saw nothing more of it. He told Billy, who told me, that it was dead, because it did not slap with 
Its tail as it went down. Next night another splashed by our boat.

This morning as we paddled we saw a little stream, very muddy, trickling into the river. Bezkya said, "Beaver at work on his dam there." Now that we were really heading for flour, our Indian showed up well. He was a strong paddler, silent but apparently cheerful, ready at all times to work. As a hunter and guide he was of course first class.

About 10.30 we came on a large Beaver sunning himself on a perch built of mud just above the water. $\mathrm{He}$ looked like a huge chestnut Muskrat. He plunged at once but came up again 30 yards farther down,

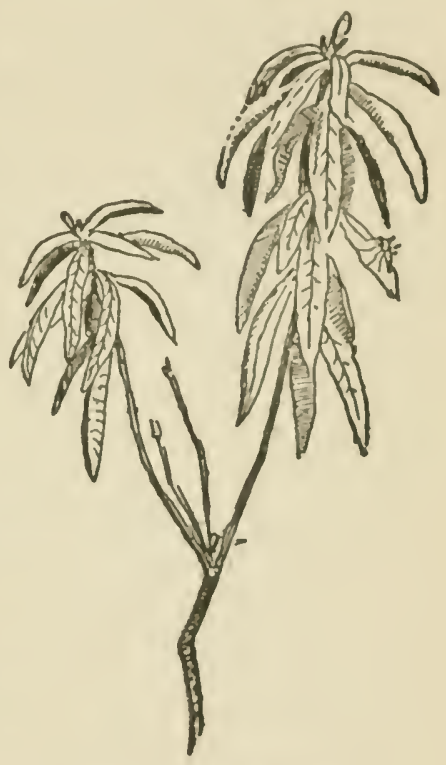

Ledum groenlandicum took another look, and dived, to be seen no more.

At noon we reached our old eamp, the last where all had been together. Here we put up a monument on a tree, and were mortified to think we had not done so at our farthest camp.

There were numbers of Yellowlegs breeding here; we were surprised to see them resting on trees or flying from one branch to another.

A Great Gray-owl sitting on a stump was a con- 
spicuous feature of our landscape view; his white choker shone like a parson's.

Early in the morning we saw a Kingbird. This was our northernmost record for the species.

We pressed on all day, stopping only for our usual supper of Moose and tea, and about 7 the boys were

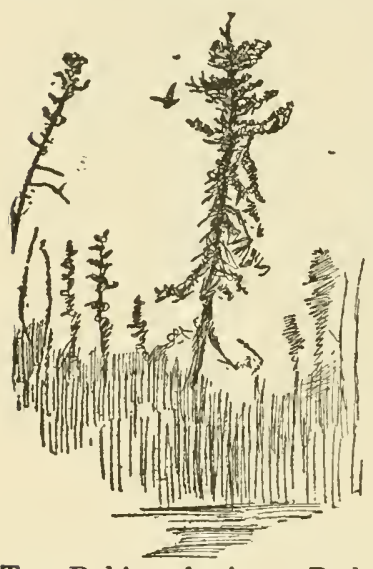

Two Robins chasing a Redtail from its own nest. July 12,1907 ready to go on again. They paddled till dark at 10. Camped in the rain, but every one was well pleased, for we had made 40 miles that day and were that much nearer to flour.

This journey had brought us down the Nyarling and $\mathbf{1 5}$ miles down the Buffalo.

It rained all night; next morning the sun came out once or twice but gave it up, and clouds with rain sprinklings kept on. We had struck a long spell of wet; it was very trying, and fatal to photographic work.

After a delicious, appetising, and inspiring breakfast of straight Moose, without even salt, and raw tea, we pushed on along the line of least resistance, i.e., toward flour.

A flock of half a dozen Bohemian Waxwings were seen catching flies among the tall spruce tops; probably all were males enjoying a stag party while their wives were home tending eggs or young.

Billy shot a female Bufflehead Duck; she was so 
small-only 8 inches in slack girth-that she could easily have entered an ordinary Woodpecker hole. So that it is likely the species nest in the abandoned holes of the Flicker. A Redtailed Hawk had its nest on a leaning spruce above the water. It was a most striking and picturesque object; doubtless the owner was very well pleased with it, but a pair of Robins militant attacked him whenever he tried to go near it.

A Beaver appeared swimming ahead; Bezkya seized his rifle and removed the top of its head, thereby spoil-

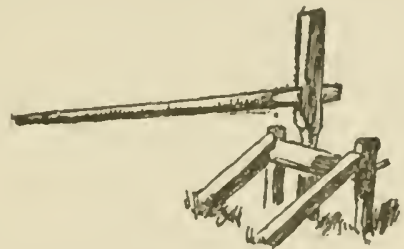

A windlass at the mouth of Little 13uffalo River. July 12, 1907

ing a splendid skull but securing a pelt and a new kind of meat. Although I was now paying his wages, the Beaver did not belong to me. According to the custom of the country it belonged to Bezkya. He owed me nothing but service as a guide. Next meal we had Beaver tail roasted and boiled; it was very delicious, but rather rich and heavy.

At 3.45 we reached Great Slave Lake, but found the sea so high that it would have been very dangerous to attempt crossing to Fort Resolution, faintly to be seen a dozen miles away.

We waited till 7 , then ventured forth; it was only 11 miles across and we could send that canoe at $5 \frac{1}{2}$ 
miles an hour, but the wind and waves against us were so strong that it took $3 \frac{1}{2}$ hours to make the passage. At 10.30 we landed at Resolution and pitched our tent among 30 teepees with 200 huge dogs that barked, scratched, howled, yelled, and fought around, in, and over the tent-ropes all night long. Oh, how different from the tranquil woods of the Nyarling!

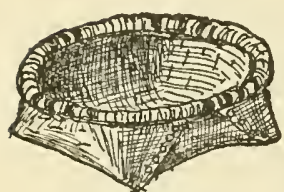

Birch bark wavey quill rim

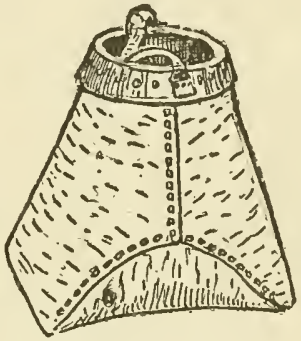

Pierre's water bucket, 10 in. high

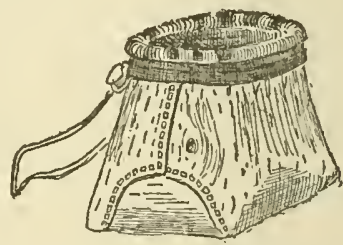

Birch bark pail spruce root wrapping

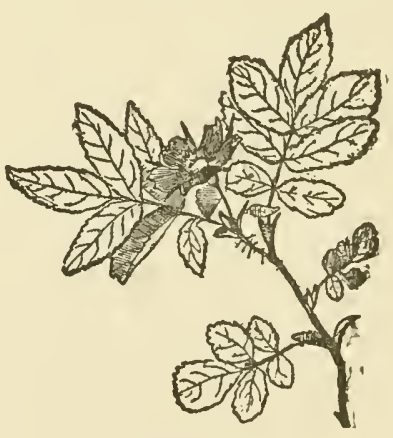

Athabaska Rose 


\section{CHAPTER XXI}

\section{FORT RESOLUTION AND ITS FOLK}

EARLY next morning Preble called on his old acquaintance, Chief Trader C. Harding, in charge of the post. Whenever we have gone to H. B. Co. officials to do business with them, as officers of the company, we have found them the keenest of the keen; but whenever it is their personal affair, they are hospitality out-hospitalled. They give without stint; they lavish their kindness on the stranger from the big world. In a few minutes Preble hastened back to say that we were to go to breakfast at once.

That breakfast, presided over by a charming woman and a genial, generous man, was one that will not be forgotten while I live. Think of it, after the hard scrabble on the Nyarling! We had real porridge and cream, coffee with veritable sugar and milk, and authentic butter, light rolls made of actual flour, unquestionable bacon and potatoes, with jam and toast - the really, truly things-and we had as much as we could eat! We behaved rather badly-intemperately, I fear-we stopped only when forced to do it, and yet both of us came away with appetites.

It was clear that I must get some larger craft than my canoe to cross the lake from Fort Resolution and take the 1,300 pounds of provisions that had come on the stcamer. Harding kindly offered the loan of a 
York boat, and with the help chiefly of Charlie McLeod the white man, who is interpreter at the fort, I secured a crew to man it. But oh, what worry and annoyance it was! These Great Slave Lake Indians are like a lot of spoiled and petulant children, with the added weakness of adult criminals; they are inconsistent, shiftless, and tricky. Pike, Whitney, Buffalo Jones, and others united many years ago in denouncing them as the most worthless and contemptible of the human race, and since then they have considerably deteriorated. There are exceptions, however, as will be seen by the record.

One difficulty was that it became known that on the Buffalo expedition Bezkya had received three dollars a day, which is government emergency pay. I had agreed to pay the regular maximum, two dollars a day with presents and keep. All came and demanded three dollars. I told them they could go at once in search of the hottest place ever pictured by a diseased and perfervid human imagination.

If they went there they decided not to stay, because in an hour they were back offering to compromise. I said I could run back to Fort Smith (it sounds like nothing) and get all the men I needed at one dollar and a half. (I should mortally have hated to try.) One by one the crew resumed. Then another bombshell. I had offended Chief Snuff by not calling and consulting with him; he now gave it out that I was here to take out live Musk-ox, which meant that all the rest would follow to seek their lost relatives. Again my crew resigned. I went to see Snuff. Every 


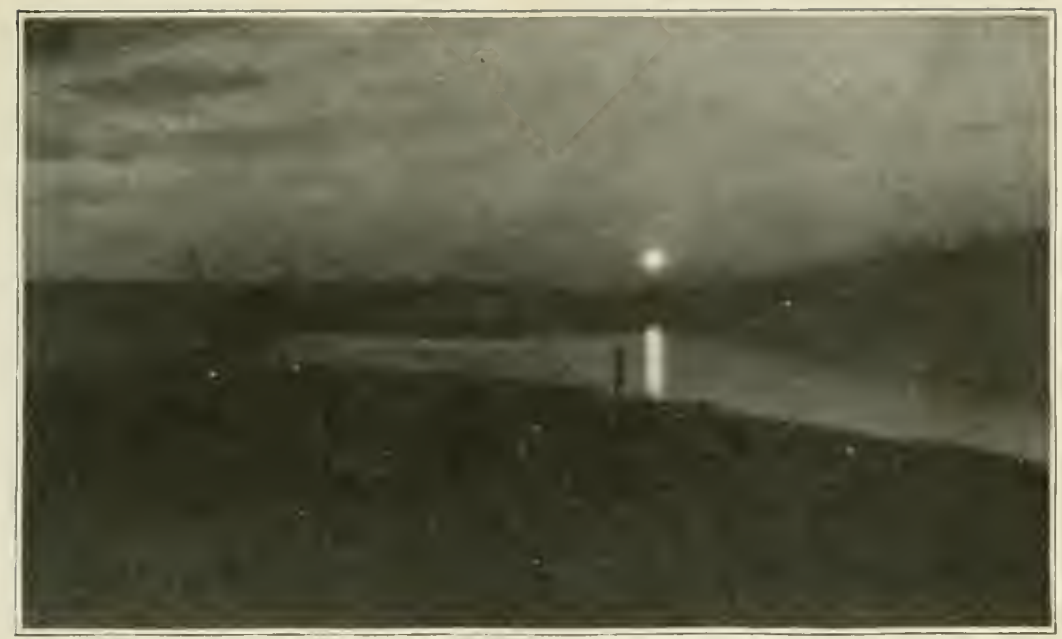

Sunset on Slave River

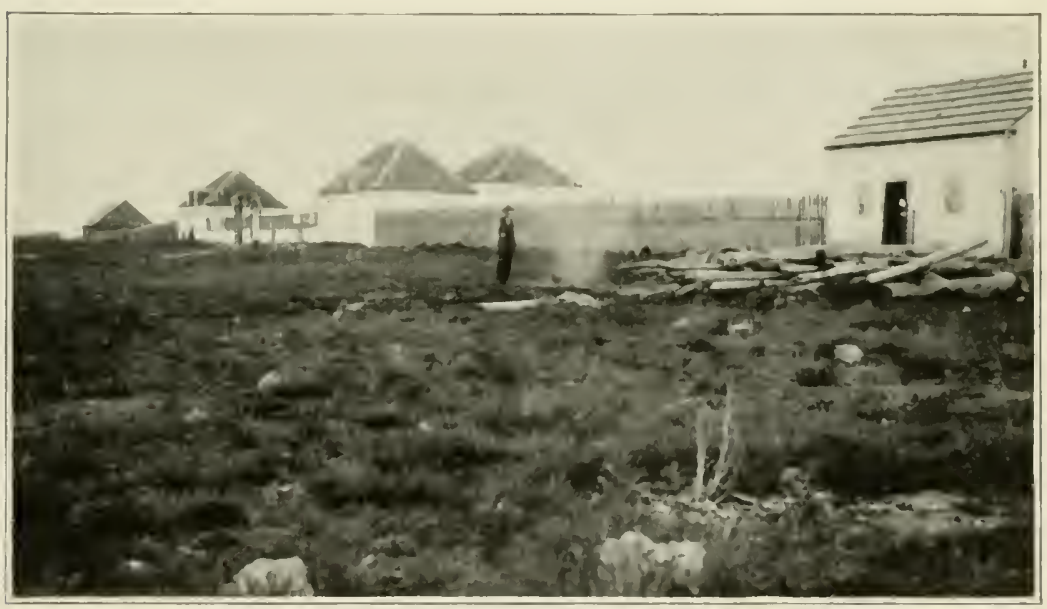

lort Resolntion 

man has his price. Snuff's price was half a pound of tea; and the erew came back, bringing, however, several new modifications in our contract.

Taking no account of several individuals that joined a number of times but finally resigned, the following, after they had received presents, provisions, and advanee pay, were the erew secured to man the York boat on the " 3 or 4" days' run to Pike's Portage and then carry my goods to the first lake.

Weeso. The Jesuits called him Louison d'Noire, but it has been corrupted into a simpler form. "Weeso" they eall it, "Weeso" they write it, and for "Weeso" you must ask, or you will not find him. So I write it as I do "Sousi" and "Yum," with the true local colour.

He was a nice, kind, simple old rabbit, not much use and not over-strong, but he did his best, never mumuring, and in all the mutinies and rebellions that followed he remained staunch, saying simply; "I gave my word I would go, and I will go." He would make a safe guide for the next party headed for Aylmer Lake. He alone did not ask rations for his wife during his absence; he said, "It didn't matter about her, as they had been married for a long time now." He asked as presents a pair of my spectacles, as his eyes were failing, and a marble axe. The latter I sent him later, but he could not understand why glasses that helped me should not help him. He acted as pilot and guide, knowing next to nothing about either.

François d'Noire, son of Weeso, a quiet, steady, inoffensive chap, but not strong; nevertheless, having 
been there once with us, he is now a competent guide to take any other party as far as Pike's Portage.

C., a sulky brute and a mischief-maker. He joined and resigned a dozen times that day, coming back on each occasion with a new demand.

S., grandson of the chief, a sulky good-for-nothing; would not have him again at any price; besides the usual wages, tobacco, food, etc., he demanded extra to support his wife during his absence. The wife, I found, was a myth.

T., a sulky good-for-nothing.

Beaulieu, an alleged grandson of his grandfather. A perpetual breeder of trouble; never did a decent day's work the whole trip. Insolent, mutinous, and overbearing, till I went for him with intent to do bodily mischief; then he became extremely obsequious. Like the rest of the foregoing, he resigned and resumed at irregular intervals.

Yum (William) Freesay; the best of the lot; a bright, cheerful, intelligent, strong Indian boy. He and my old standby, Billy Loutit, did virtually all the handling of that big boat. Any one travelling in that country should secure Yum if they can. He was worth all the others put together.

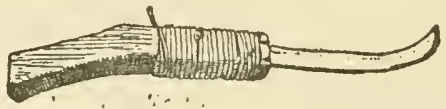

Bess-hath or crooked knife. $10 \frac{1}{2}$ in. long. Property of Weeso. Made of a file. July 16, 1907 


\section{CHAPTER XXII}

THE CHIPEWYANS, TIIEIR SP'EECH AND WRITING

Sweeprng generalisations are always misleading, therefore I offer some now, and later will correct them by specific instances.

These Chipewyans are dirty, shiftless, improvident, and absolutely honest. Of the last we saw daily instances in crossing the country. Valuables hung in trees, protected only from weather, birds, and beasts, but never a suggestion that they needed protection from mankind. They are kind and hospitable among themselves, but grasping in their dealings with white men, as already set forth. While they are shiftless and lazy, they also undertake the frightful toil of hunting and portaging. Although improvident, they have learned to dry a stock of meat and put up a scaffold of white fish for winter use. As a tribe they are mild and inoffensive, although they are the original stock from which the Apaches broke away some hundreds of years ago before settling in the south.

They have suffered greatly from diseases imported by white men, but not from whiskcy. The Hudson's Bay Company has always refused to supply liquor to the natives. What little of the evil traffic there has been was the work of free-traders. But the Royal Mounted Police have most rigorously and effectually 
suppressed this. Nevertheless, Chief Trader Anderson tells me that the Mackenzie Valley tribes have fallen to less than half their numbers during the last century.

It is about ten years since they made the treaty that surrendered their lands to the government. They have no reserves, but are free to hunt as their fathers did.

I found several of the older men lamenting the degeneracy of their people. "Our fathers were hunters and our mothers made good moccasins, but the young men are lazy loafers around the trading posts, and the women get money in bad ways to buy what they should make with their hands."

The Chipewyan dialects are peculiarly rasping, clicking, and guttural, especially when compared with Cree.

Every man and woman and most of the children among them smoke. They habitually appear with a pipe in their mouth and speak without removing it, so that the words gurgle out on each side of the pipe while a thin stream goes sizzling through the stem. This additional variant makes it hopeless to suggest on paper any approach to their peculiar speech.

The Jesuits tell me that it was more clicked and guttural fifty years ago, but that they are successfully weeding out many of the more unpleasant catarrhal sounds.

In noting down the names of animals, I was struck by the fact that the more familiar the animal the shorter its name. Thus the Beaver, Muskrat, Rabbit, and Marten, on which they live, are respectively Tsa, Dthen, Ka, and Tha. The less familiar (in a daily 
sense) Red Fox and Weasel are Nak-ee-they, Noondee-a, Tel-ky-lay; and the comparatively scarce Muskox and little Weasel, At-huh-le-jer-ray and Tel-kylay-azzy. All of which is clear and logical, for the name originally is a description, but the softer parts and sharp angles are worn down by the attrition of use-
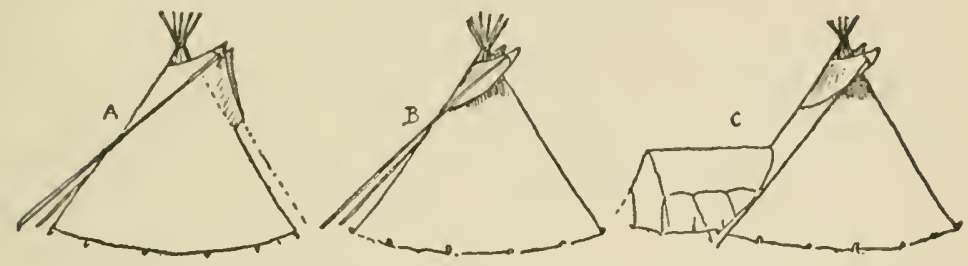

A. Typical teepee of Plains Indians. B. Chipewyan tcepee with smoke flaps of a separate piece. C. MIodern Chipewyan teepee with tent addition

the more use they have for a word the shorter it is bound to get. In this connection it is significant that "to-day" is To-ho-chin-nay, and "to-morrow" Kon'pay.

The Chipewyan teepee is very distinctive; fifty years ago all were of caribou leather, now most are of cotton; not for lack of caribou, but because the cotton does not need continual watching to save it from the dogs. Of the fifty teepees at Fort Chiperyan, one or two only were of caribou but many had caribou-skin tops, as these are less likely to burn than those of cotton.

The way they manage the smoke is very clever; instead of the two fixed flaps, as among the Plains River Indians, these have a separate hood which is easily set on any side (sce III). Chief Squirrel lives in a lodge that is an admirable combination of the white 
men's tent with its weather-proof roof and the Indian teepee with its cosy fire. (See cut, p. 149.)

Not one of these lodges that I saw, here or elsewhere, had the slightest suggestion of decoration.

For people who spend their whole life on or near the water these are the worst boatmen I ever saw. The narrow, thick paddle they make, compared with the

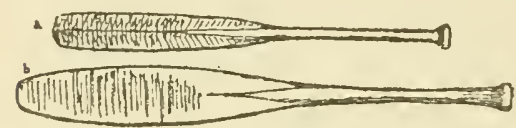

$a$. Chipewyan paddle. $b$. Iroquois paddle

broad, thin Iroquois paddle, exactly expressed the difference between the two as canoemen. The Chipewyan's mode of using it is to sit near the middle and make 2 or perhaps 3 strokes on one side, then change to the other side for the same, and so on. The line made by the canoes is an endless zigzag. The idea of paddling on one side so dexterously that the canoe goes straight is yet on an evolutionary pinnacle beyond their present horizon.

In rowing, their way is to stand up, reach forward with the 30 -pound $16 \frac{1}{2}$-foot oar, throw all the weight on it, falling backward into the seat. After half an hour of this exhausting work they must rest 15 to 20 minutes. The long, steady, strong pull is unknown to them in every sense.

Their ideas of sailing a boat are childish. Tacking is like washing, merely a dim possibility of their very distant future. It's a sailing wind if behind; otherwise it's a case of furl and row.

By an ancient, unwritten law the whole country is roughly divided among the hunters. Each has his 
own recognised hunting ground, usually a given river valley, that is his exclusive and hereditary property; another hunter may follow a wounded animal into it, but not begin a hunt there or set a trap upon it.

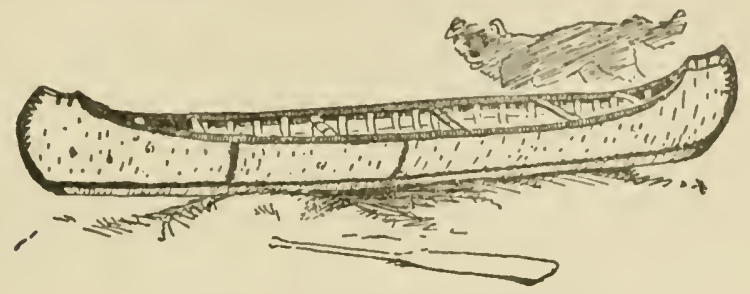

Chipewyan canoe, Smith Landing

Most of their time is spent at the village, but the hunting ground is visited at proper seasons.

Fifty years ago they commonly went half naked. How they stood the insects I do not know, and when asked they merely grinned significantly; probably they doped themselves with grease.

This religious training has had one bad effect. Inspired with horror of being "naked" savages, they do not run any sinful risks, even to take a bath. In all

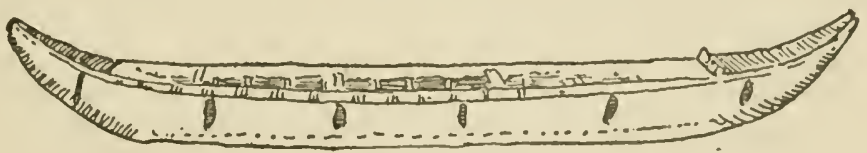

Dogrib canoe

the six months I was among them I never saw an Indian's bare arms, much less his legs. One day after the fly scason was over I took advantage of the lovely weather and water to strip off and jump into a lake by our camp; my Indians modestly turned their backs until I had finished. 
If this mock modesty worked for morality one might well accept it, but the old folks say that it operates quite the other way. It has at all events put an end to any possibility of them taking a bath.

Maybe as a consequence, but of this I am not sure, none of these Indians swim. A large canoe-load upset in crossing Great Slave Lake a month after we arrived and all were drowned.

Like most men who lead physical lives, and like all meat-eating savages, these are possessed of a natural proneness toward strong drink.

An interesting two-edged boomerang illustration of this was given by an unscrupulous whiskey trader. While travelling across country he ran short of provisions but fortunately came to a Chipewyan lodge. At first its owner had no meat to spare, but when he found that the visitor had a flask of whiskey he offered for it a large piece of Moose meat; when this was refused he doubled the amount, and after another refusal added some valuable furs and more meat till one hundred dollars worth was piled up.

Again the answer was "no."

Then did that Indian offer the lodge and everything he had in it, including his wife. But the trader was obdurate.

"Why didn't you take it," said the friend whom he told of the affair; "the stuff would have netted five hundred dollars, and all for one flask of whiskey."

"Not much," said the trader, "it was my last flask. I wouldn't 'a' had a drop for myself. But it just shows how fond these Indians are of whiskey." 
While some of the Chipewyans show fine physique, and many do great feats of strength and endurance, they seem on the whole inferior to whites.

Thus the strongest portager on the river is said to be Billy Loutit's brother George. At Athabaska Landing I was shown a house on a hill, half a mile away, to which he had carried on his back 450 pounds of flour without stopping. Some said it was only 350 pounds, but none made it less. As George is only three-quarters white, this is perhaps not a case in point. But during our stay at Fort Smith we had several athletic meets of Indians and whites, the latter represented by Preble and the police boys, and no matter whether in running, walking, high jumping, broad jumping, wrestling, or boxing, the whites were ahead.

As rifle-shots, also, the natives scem far inferior. In the matter of moose-hunting only, as already noted, the red-man was master. This, of course, is a matter of life-long training. A white man brought up to it would probably do as well as an Indian even in this very Indian department.

These tribes are still in the hunting and fishing stage; they make no pretence of agriculture or stock-raising. Except that they wear white man's clothes and are most of them nominally Roman Catholics, they live as their fathers did 100 years ago. But there is one remarkable circumstance that impressed me more and more-practically every Chipewyan reads and writes his own language.

This miracle was inborn on me slowly. On the first Buffalo hunt re had found a smoothened pole stuck in 
the ground by the trail. It was inscribed as here. with.

"What is that Sousi?" "It's a notice from Chief William that Swiggert wants men on the portage," and he translated it literally: "The fat white man 5 scows, small white man 2 scows, gone down, men wanted for Rapids, Johnnie Bolette this letter for you. (Signed) Chief William."

Each of our guides in succession had shown a similar familiarity with the script of his people, and many

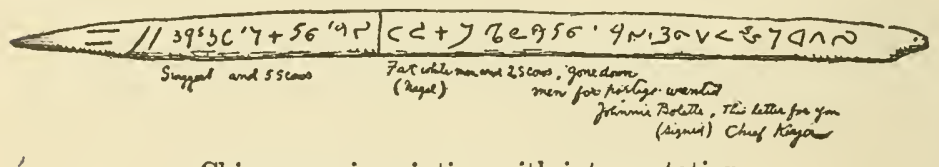

Chipewyan inscription with interpretation

times we found spideresque characters on tree or stone that supplied valuable information. They could, however, tell me nothing of its age or origin, simply "We all do it; it is easy."

At Fort Resolution I met the Jesuit fathers and got the desired chance of learning about the Chipewyan script.

First, it is not a true alphabet, but a syllabic; not letters, but syllables, are indicated by each character; 73 characters are all that are needed to express the whole language. It is so simple and stenographic that the fathers often use it as a rapid way of writing French. It has, however, the disadvantage of ambiguity at times. Any Indian boy can learn it in a week or two; practically all the Indians use it. What a commentary on our own cumbrous and illogical spell- 
ing, which takes even a bright child two or three years to learn!

Now, I already knew something of the Cree syllabic invented by the Rev. James Evans, Methodist missionary on Lake Winnipeg in the '40s, but Cree is a

\begin{tabular}{|c|c|c|c|c|}
\hline$\triangle a$ & $\nabla \mathrm{e}$ & $\Delta i$ & $\triangle 0$ & - $\tau^{n} \Delta$ \\
\hline$\checkmark$ an & $\nabla^{\prime}$ en & $\Delta^{\prime}$ in & D'On & - Ed. \\
\hline$<$ ba & $\checkmark$ be & $\wedge$ bi & $>$ bo & תז'ד , \\
\hline$C$ da & $U$ de & $\cap$ di & $\supset$ do & . UDd \\
\hline b ka & $9 \mathrm{ke}$ & $P \mathrm{ki}$ & $d$ ko & ' రన' \\
\hline$e^{\mathrm{la}}$ & U le & $\Omega \mathbf{l i}$ & bا & ‘ ऽ \\
\hline L ma & $7 \mathrm{me}$ & $\Gamma \mathrm{mi}$ & \rfloor $\mathrm{mo}$ & ת \\
\hline Q na & O ne & $\sigma$ ni & D no & - $\nabla 2 a$. \\
\hline 七ra & q re & $r$ ri & J ro & $n 2 n$ \\
\hline S sa & $4 \mathrm{se}$ & $\sim$ si & $\sim$ so & 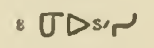 \\
\hline ל ya & $\angle$ ye & $\rightarrow$ yi & < yо & • \ব \\
\hline б za & 10 zе & el $2 \mathrm{i}$ & $\delta 20$ & - 4ranir \\
\hline$E$ cha & $W$ che & $m$ chi & 3 cho & $\Delta D U^{\prime} \Delta$ \\
\hline$\checkmark$ dha & ר dhe & $\cap \mathrm{dhi}$ & $\bigcup$ dho & $=\Delta \cdot-\Delta c$ \\
\hline U tha & in the & on thi & $U$ tho & - $\nabla \mathcal{C}_{0}$ \\
\hline$C^{\prime}$ ta & U'te & $n^{\prime} t i$ & $J^{\prime}$ tto & י ' \\
\hline$\in$ tha & $\cup$ the & ก t thi & $\Rightarrow$ tho & $\cdot \Delta C$ \\
\hline$t_{a}$ & U i & $\cap \mathbb{t q}^{\mathfrak{a}}$ & כז & \\
\hline
\end{tabular}

Chipewyan syllabic alphabet

much less complex language; only 36 characters are needed, and these are so simple that an intelligent Cree can learn to write his own language in one day.

In support of this astounding statement I give, first, the 36 characters which cover every fundamental sound in their language and then a sample of application. While crude and inconcise, it was so logical and simple 
that in a few years the missionary had taught practically the whole Cree nation to read and write. And

\section{SYLLABARIUM}

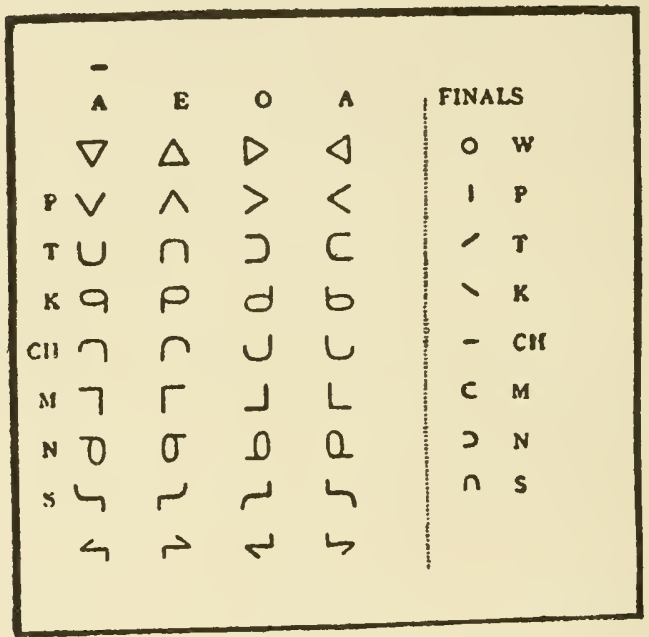

A dot gives a "w" sound

EXAMPLES.

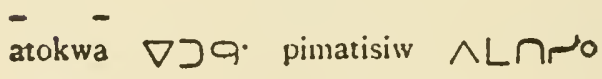

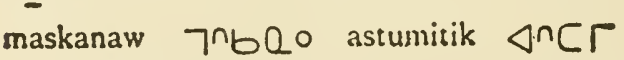

ก. makwach $70^{-}$ustootin $\Delta n \supset \cap^{3}$

pimachehewam $\wedge L \cap \triangle \nabla \cdot c$ kakwi $96:$

The syllabic alphabet of the Cree language

Lord Dufferin, when the matter came before him during his north-west tour, said enthusiastically: "There have been men buried in Westminster Abbey with national honours whose claims to fame were far less 
than those of this devoted missionary, the man who taught a whole nation to read and write."

These things I knew, and now followed up my Jesuit source of information.

"Who invented this?"

"I don't know for sure. It is in general use."

"Was it a native idea?"

"Oh, no; some white man made it."

"Where? Here or in the south?"

"It came originally from the Crees, as near as we can tell."

"Was it a Cree or a missionary that first thought of it?"

"I believe it was a missionary."

"Frankly, now, wasn't it invented in 1840 by Rev. James Evans, Methodist missionary to the Crees on Lake Winnipeg?"

Oh, how he hated to admit it, but he was too honest to deny it.

"Yes, it seems to me it was some name like that. 'Je ne sais pas.'"

Reader, take a map of North America, a large one, and mark off the vast area bounded by the Saskatchewan, the Rockies, the Hudson Bay, and the Arctic circle, and realise that in this region, as large as continental Europe outside of Russia and Spain, one simple, earnest man, inspired by the love of Him who alone is perfect love, invented and popularised a method of writing that in a few years-in less than a generation, indeedhas turned the whole native population from ignorant illiterates to a people who are proud to read and write 
their own language. This, I take it, is one of the greatest feats of a civiliser. The world has not yet heard of, much less comprehended, the magnitude of the achievement; when it does there will be no name on the Canadian roll of fame that will stand higher or be blazoned more brightly than that of James Evans the missionary.

\section{(n) UT}

(2) $\wedge \zeta^{s}$ ก 4
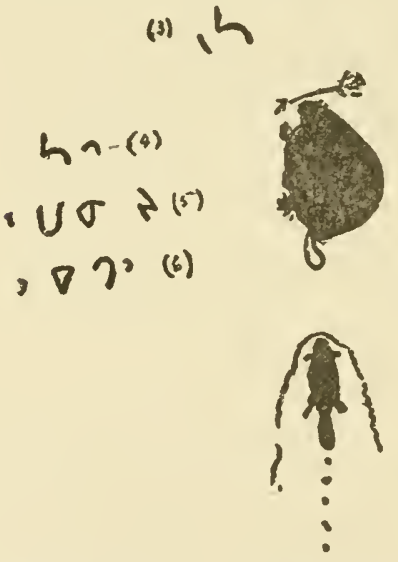

(1) Tinné. (2) Peter Squirrel. (3) Tsa or Beaver. (4) Sass or Bear. (5) Den-nee or Moose. (6) Et-then or Deer 


\section{CHAPTER XXIII}

\section{THE DOGS OF FOR'T RESOLUTION}

IT sounds like the opening of an epic poem but it is not.

The Chipewyan calender is divided in two seasonsdog season and canoe season. What the horse is to the Arab, what the Reindeer is to the Lap and the Yak to the Thibetan, the dog is to the Chipewyan for at least one-half of the year, until it is displaced by the canoe.

During dog season the canoes are piled away somewhat carelessly or guarded only from the sun. During canoe season the dogs are treated atrociously. Let us remember, first, that these are dogs in every doggy sense, the worshipping servants of man, asking nothing but a poor living in return for abject love and tireless service, as well as the relinquishment of all family ties and natural life. In winter, because they cannot serve without good food, they are well fed on fish that is hung on scaffolds in the fall in time to be frozen before wholly spoiled. The journeys they will make and the devoted service they render at this time is none too strongly set forth in Butler's "Cerf Vola" and London's "Call of the Wild." It is, indeed, the dog alone that makes life possible during the white half-year of the boreal calender. One cannot be many 
days in the north without hearing tales of dog prowess, devotion, and heroism. A typical incident was related as follows by Thomas Anderson:

Over thirty years ago, Chief Factor George McTavish and his driver, Jack Harvey, were travelling from East Main to Rupert's House (65 miles) in a blizzard so thick and fierce that they could scarcely see the leading dog. He was a splendid, vigorous creature, but all at once he lay down and refused to go. The driver struck him, but the factor reproved the man, as this dog had never needed the whip. The driver then went ahead and found open water only a few feet from the dogs, though out of sight. After that they gave the leader free rein, surrendered themselves to his guidance, and in spite of the blinding blizzard they struck the flagpole of Rupert's between 11 and 12 that night, only a little behind time.

Many of the wild Wolf traits still remain with them. They commonly pair; they bury surplus food; the mothers disgorge food for the young; they rally to defend one of their own clan against a stranger; and they punish failure with death.

A thousand incidents might be adduced to show that in the north there is little possibility of winter travel without dogs and little possibility of life without winter travel.

But April comes with melting snows and May with open rivers and brown earth everywhere; then, indeed, the reign of the dog is over. The long yellowbirch canoe is taken down from the shanty roof or from a sheltered scaffold, stitched, gummed, and launched; 
and the dogs are turned loose to fend for themselves. Gratitude for past services or future does not enter into the owner's thoughts to secure a fair allowance of food. All their training and instinet prompts them to hang about camp, where, kicked, stoned, beaten, and starved, they steal and hunt as best they may, until the sad season of summer is worn away and merry winter with its toil and good food is back once more.

From leaving Fort MaeMurray we saw daily the starving dog, and I fed them when I could. At Smith Landing the daily dog became a daily fifty. One big fellow annexed us. "I found them first," he seemed to say, and no other dog came about our camp without a fight.

Of course he fared well on our seraps, but many a time it made my heart ache and my food-store suffer to see the gaunt skeletons in the bushes, just beyond his sphere of influence, watching for a chance to rush in and secure a mouthful of - anything to stay the devastating pang. My journal of the time sets forth in full detail the diversity of their diet, not only every possible scrap of fish and meat or whatsoever smelled of fish or meat, but rawhide, leather, old boots, flourbags, potato-peelings, soap, wooden fragments of meatboxes, rags that have had enough animal contact to be odorous. An ancient dish-cloth, sueculent with active service, was eonsidered a treat to be bolted whole; and when in due eourse the cloth was returned to earth, it was intact, bleached, purged, and purified as by chemic fires and ready for a new round of benevolenees. 
In some seasons the dogs catch Rabbits enough to keep them up. But this year the Rabbits were gone. They are very clever at robbing fish-nets at times, but these were far from the fort. Reduced to such desperate straits for food, what wonder that cannibalism should be common! Not only the dead, but the sick or disabled of their own kind are torn to pieces and devoured. I was told of one case where a brutal driver disabled one of his dogs with heavy blows; its companions did not wait till it was dead before they feasted. It is hard to raise pups because the mothers so often devour their own young; and this is a charge I never heard laid to the Wolf, the ancestor of these dogs, which shows how sadly the creature has been deteriorated by contact with man. There seems no length to which they will not go for food. Politeness forbids my mentioning the final diet for which they scramble around the camp. Never in my life before have I seen such utter degradation by the power of the endless hunger pinch. Nevertheless-and here I expect the reader to doubt, even as I did when first I heard it, no matter how desperate their straits-these gormandisers of unmentionable filth, these starvelings, in their dire extremity will turn away in disgust from duck or any other web-footed water-fowl.

Billy Loutit had shot a Pelican; the skin was carefully preserved and the body guarded for the dogs, thinking that this big thing, weighing 6 or 7 pounds, would furnish a feast for one or two. The dogs knew me, and rushed like a pack of Wolves at sight of coming food. The bigger ones fought back the smaller. 
I threw the prize, but, famished though they were, they turned away as a man might turn from a roasted human hand. One miserable creature, a mere skeleton, sneaked forward when the stronger ones were gone, pulled out the entrails at last, and devoured them as though he hated them.

I can offer no explanation. But the Hudson's Bay men tell me it is always so, and I am afraid the remembrance of the reception accorded my bounty that day hardened my heart somewhat in the days that followed.

On the Nyarling we were too far from mankind to be bothered with dogs, but at Fort Resolution we reentered their country. The following from my journal records the impression after our enforced three days' stay:

"Tuesday, July 16, 1907.-Fine day for the first time since July 3. At last we pulled out of Fort Resolution (9.40 А. Mr.). I never was so thankful to leave a place where every one was kind. I think the maddest cynophile would find a cure here. It is the worst dog-eursed spot I ever saw; not a square yard but is polluted by them; no article can be left on the ground but will be carried off, torn up, or defiled; the four corners of our tent have become regular stopping places for the countless canines, and are disfigured and made abominable, so that after our escape there will be needed many days of kindly rain for their purification.

"There certainly are several hundred dogs in the village; there are about 50 tecpees and houses with 5 to 15 
dogs at each, and 25 cach at the mission and H. B. Co. In a short walk, about 200 yards, I passed $\$ 6$ dogs.

"There is not an hour or ten minutes of day or night that is not made hideous with a dog-fight or chorus of yclps. There are about six different clans of dogs, divided as their owners are, and a Dogrib dog entering the Yellow-knife or Chipewyan part of the camp is immediately set upon by all the residents. Now the clansmen of the one in trouble rush to the reseue and there is a battle. Indians of both sides join in with clubs to belabour the fighters, and the yowling and yelping of those discomfited is painful to hear for long after the fight is over. It was a battle like this, I have been told, which caused the original split of the tribe, one part of which went south to become the Apaches of Arizona. The scenes go on all day and all night in different forms. A number of dogs are being broken in by being tied up to stakes. These keep up a heartrending and peculiar crying, beginning with a short bark which melts into a yowl and dies away in a nerveracking wail. This ceases not day or night, and half a dozen of these prisoners are within a stone's throw of our camp.

"The favourite place for the clan fights seems to be among the guy-ropes of our tent; at least half a dozen of these general engagements take place every night while we try to sleep.

"Everything must be put on the high racks eight feet up to be safe from them; even empty tins are carried off, boots, hats, soap, etc., are esteemed most toothsome morsels, and what they can neither eat, carry off, nor 
destroy, they defile with elaborate persistency and precision."

A common trick of the Indians when canoe season arrives is to. put all the family and one or two of the best dogs in the canoes, then push away from the shore, leaving the rest behind. Those so abandoned come howling after the canoes, and in unmistakable pleadings beg the heartless owners to take them in. But the canoes push off toward the open sea, aiming to get out of sight. The dogs howl sadly on the shore, or swim after them till exhausted, then drift back to the nearest land to begin the summer of hardship.

If Rabbits are plentiful they get along; failing these they eatch mice or fish; when the berry season comes they eat fruit; the weaker ones are devoured by their brethren; and when the autumn arrives their insensate owners generally manage to come back and pick up the survivors, feeding them so that they are ready for travel when dog-time begins, and the poor faithful brutes, bearing no grudge, resume at once the service of their unfecling masters.

All through our voyage up Great Slave Lake we daily heard the sad howling of abandoned dogs, and nightly, we had to take steps to prevent them stealing our food and leathers. More than once in the dim light, I was awakened by a rustle, to see sneaking from my tent the gray, wolfish form of some prowling dog: and the resentment I felt at the loss inflicted, was never more than to make me shout or throw a pebble at him. 
One day, as we voyaged eastward (July 23) in the Tal-thel-lay narrows of Great Slave Lake, we met 5 canoes and 2 York boats of Indians going west. A few hours afterward as we were nooning on an island (we were driven to the islands now) there came a long howling from the rugged main shore, a mile away to the east of us; then it increased to a chorus of wailing, and we knew that the Indiaris had that morning abandoned their dogs there. The wailing continued, then we saw a tiny black speck coming from the far shore. When it was half-way across the ice-cold bay we could hear the gasps of a tired swimmer. He got along fairly, dodging the cakes of ice, until within about 200 yards, when his course was barred by a long, thin, drifting floe. He tried to climb on it, but was too weak, then he raised his voice in melancholy howls of despair. I could not get to him, but he plucked up heart at length, and feebly paddling went around till he found an opening, swam through and came on, the slowest dog swimmer I ever saw. At last he struck bottom and crawled out. But he was too weak and ill to eat the meat that I had ready prepared for him. We left him with food for many days and sailed away.

Another of the dogs that tried to follow him across was lost in the ice; we heard his miserable wailing moans as he was carried away, but could not help him. My Indians thought nothing of it and were amused at my solicitude.

A couple of hours later we landed on the rugged east coast to study our course through the ice. At once 


\section{THE DOGS OF FORT RESOLUTION 167}

we were met by four dogs that trotted along the shore to where we landed. 'They did not seem very gaunt; one, an old yellow female, carried something in her mouth; this she never laid down, and growled savagely when any of the others came near. It proved to be the blood-stained leg of a new-killed dog, yellow like herself.

As we pulled out a big black-and-white fellow looked at us wistfully from a rocky ledge; memories of Bingo, whom he resembled not a little, touched me. I threw him a large piece of dried meat. He ate it, but not ravenously. He seemed in need, not of food, but of company.

A few miles farther on we again landed to study the lake; as we came near we saw the dogs, not four but six, now racing to mect us. I said to Preble: "It scems to me it would be the part of merey to shoot them all." He answered: "They are worth nothing now, but you shoot one and its value would at once jump up to one hundred dollars. Every one knows everything that is done in this, country. You would have six hundred dollars' damages to pay when you got back to Fort Resolution."

I got out our stock of fresh fish. The Indians, sceing my purpose, said: "Throw it in the water and see them dive." I did so and found that they would dive into several feet of water and bring up the fish without fail. The yellow female was not here, so I suppose she had stayed to finish her bone.

When we came away, heading for the open lake, the dogs followed us as far as they could, then gathering 
on a flat rock, the end of a long point, they sat down, some with their backs to us; all raised their muzzles and howled to the sky a heart-rending dirge.

I was thankful to lose them in the distance.

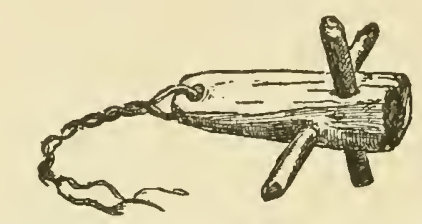

Dog-toggle or clog, Smith Landing 


\section{CHAPTER XXIV}

\section{THE VOYAGE ACROSS THE LAKE}

Hitherto I have endeavoured to group my observations on each subject; I shall now for a change give part of the voyage across Great Slave Lake much as it appears in my joumal.

"July 16, 1907.-Left Fort Resolution at 9.40 A. . in the York boat manned by 7 Indians and Billy Loutit, besides Preble and myself, 10 in all; ready with mast and sail for fair wind, but also provided with heavy 16-foot oars for head-winds and calm. Harding says we should make Pike's Portage in 3 or 4 days.

"Reached Moose Island at 11.30 chicfly by rowing; camped. A large dog appeared on the bank. Freesay recognised it as his and went ashore with a club. We heard the dog yelping. Freesay came back saying: 'He'll go home now.'

"At 1.30 went on but stopped an unnecessary halfhour at a saw-mill getting plank for seats. Reached the Big, or Main, River at 4.10; stopped for tea again till 4.50, then rowed up the river till 5.40; rested 15 minutes, rowed till 6.30 ; rested 15 minutes, rowed till 7 ; then got into the down eurrent of the north branch or mouth of the Slave; down then we drifted till S, then landed and made another meal, the fourth to-day, and went on drifting at $S .30$. 
"At 9.30 we heard a Ruffed Grouse drumming, the last of the season, also a Bittern pumping, some Cranes trumpeting, and a Wood Frog croaking. Snipe were still whirring in the sky. Saw Common Tern.

"At 10.15, still light, we camped for the night and made another meal. The Indians went out and shot 2 Muskrats, making 7 the total of these $I$ have seen in the country. This is the very lowest ebb. Why are they so scarce? Their low epoch agrees with that of the Rabbits.

"July 17.-Rose at 6 (it should have been 4 , but the Indians would not rouse); sailed north through the marsh with a light east breeze. At noon this changed to a strong wind blowing from the north, as it has done with little variation ever since I came to the country. These Indians know little of handling a boat and resent any suggestion. They maintain their right to row or rest, as they please, and land when and where they think best. We camped on a sand-bar and waited till night; most exasperating when we are already behind time. The Indians set a net, using for tiestrings the bark of the willow (Salix bebbiana). They caught a Jack-fish. Reached Stony Island at night, after many stops and landings. The Indians land whenever in doubt and make a meal (at my expense), and are in doubt every two hours or so. They eat by themselves and have their own cook. Billy cooks for us, i.e., Preble, Weeso, and myself. Among the crew I hear unmistakable grumblings about the food, which is puzzling, as it is the best they ever had in their lives; there is great variety and no limit to the quantity. 


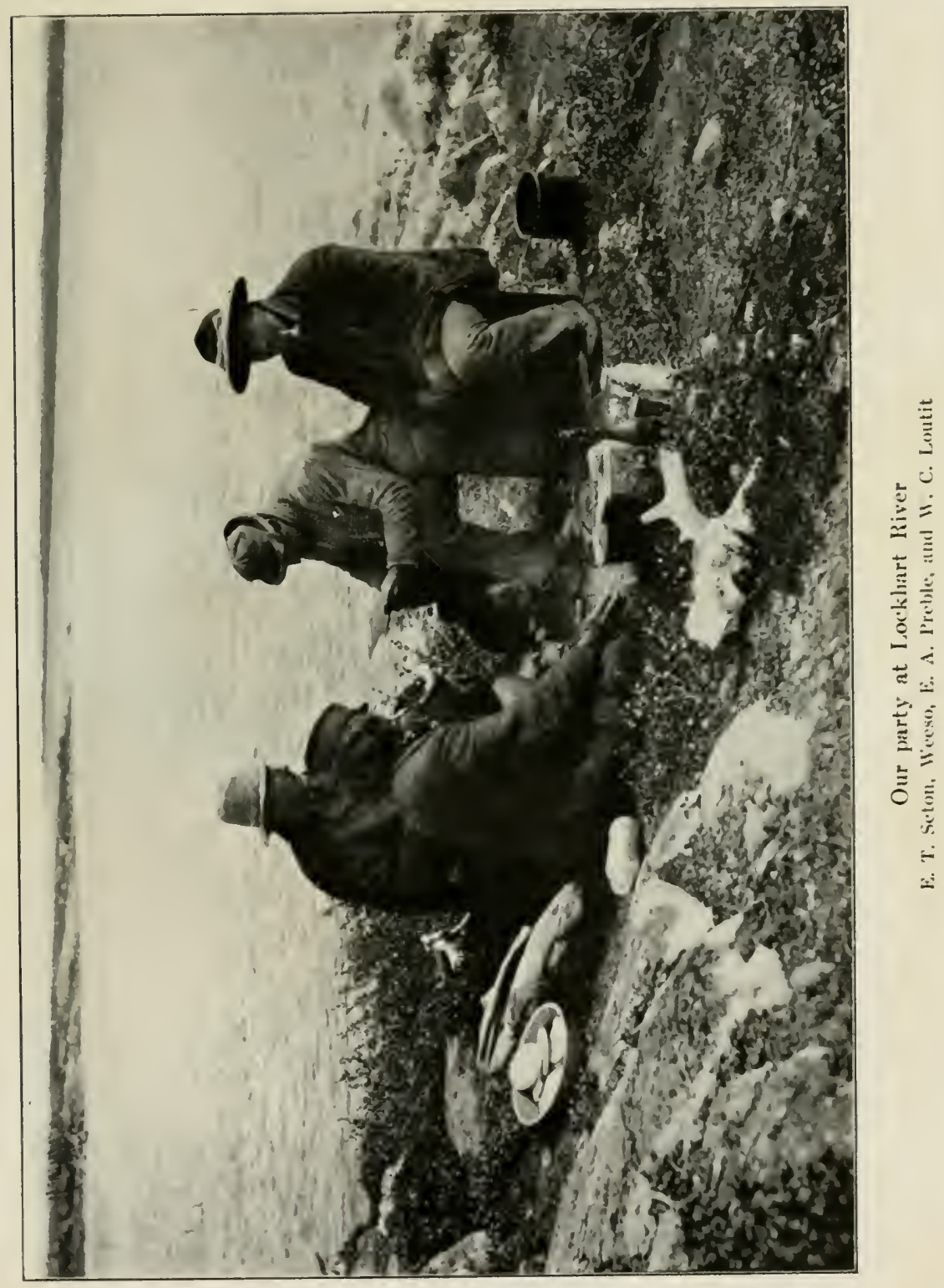



"Made 6 meals and 17 miles to-day, rowing 7, sailing 10.

"July 18.-Left Stony Island at 6.55; could not get the crew started sooner; sailing with a light breeze which soon died down and left us on a sea of glass. I never before realised how disgusting a calm could be.

"Camped at 9.15 on one of the countless, unnamed, uncharted islands of the lake. It is very beautiful in colour, red granite, spotted with orange and black lichen on its face, and carpeted with caribou moss and species of cetraria, great patches of tripe-de-roche, beds of saxifrage, long trailers, and masses of bearberry, empetrum, ground cedar, juniper, cryptograma, and many others; while the trees, willow, birch, and spruce are full of character and drawing. Sky and lake are in colour worthy of these rich details, the bird life is well represented and beautiful; there is beauty everywhere, and 'only man is vile.'

"I am more and more disgusted with my Indian crew; the leader in mischief seems to be young Beaulieu. Yesterday he fomented a mutiny because I did not give them 'beans,' though I had given them far more than promised, and beans were never mentioned. Still, he had discovered a bag of them among my next month's stores, and that started him.

"Tu-day, when sick of seeing them dawdling two hours over a meal when there are 6 meals a day, I g. ve the order to start. Beaulieu demanded insolently: 'Jh! who's boss?' My patience was worn out. I said: 'I am, and I'll show you right now,' and proceeded to do so, meaning to let him have my fist with 
all the steam I could get back of it. But he did not wait. At a safe distance he turned and in a totally different manner said: 'I only want to know; I thought maybe the old man (the guide). I'll do it, all ri, all ri,' and he smiled and smiled.

"Oh! why did I not heed Pike's warning to shun all Beaulieus; they rarely fail to breed trouble. If I had realised all this last night before coming to the open lake I would have taken the whole outfit back to Resolution and got rid of the crowd. We could do better with another canoe and two men, and at least make better time than this ( 17 miles a day).

"Yesterday the Indian boys borrowed my canoe, my line, and in my time, at my expense, caught a big fish, but sullenly disregarded the suggestion that I should have a piece of it.

"Each of them carries a Winchester and blazes away at every living thing that appears. They have volleyed all day at every creature big enough to afford a mouthful-Ducks, Gulls, Loons, Fish, Owls, Terns, etc.-but have hit nothing. Loons are abundant in the water and are on the Indians' list of Ducks, therefore good food. They are wonderfully expert at calling them. This morning a couple of Loons appeared flying far to the east. The Indians at once began to mimic their rolling whoo-000-whoo-00o; doing it to the life. The Loons began to swing toward us, then to circle, each time nearer. Then all the callers stopped except Claw-hammer, the expert; he began to utter a peculiar cat-like wail. The Loons responded and dropped their feet as though to alight. Then at 40 yards the whole 
crew blazed away with their rifles, doing no damage whatever. 'The Loons turned away from these unholy' callers, and were none the worse, but wiser.

"This scene was repeated many times during the voyage. When the Loons are on the water the Indians toll them by flashing a tin pan from the bushes behind which the toller hides till the bird is in range. I saw many clever tollings but I did not see a Loon killed.

"July 19.-I got up at 4, talked strong talk, so actually got away at 5.30. Plenty grumbling, many meals to-day, with many black looks and occasional remarks in English: 'Grub no good.' Three days ago these men were starving on one meal a day, of fish and bad flour; now they have bacon, dried venison, fresh fish, fresh game, potatoes, flour, baking powder, tea, coffee, milk, sugar, molasses, lard, cocoa, dried apples, rice, oatmeal, far more than was promised, all ad libitum, and the best that the II. B. Co. can supply, and yet they grumble. There is only one article of the food store to which they have not access; that is a bag of beans which I am reserving for our own trip in the north where weight counts for so much. Beaulieu smiles when I speak to him, but I know he is at the bottom of all this mischief. To day they made 6 meals and 17 miles-this is magnificent.

"About 7.30 a pair of Wild Geese (Canada) appeared on a bay. The boys let off a whoop of delight and rushed on them in canoe and in boat as though these were their deadliest enemies. I did not think much of it until I noticed that the Geese would not fly, and it 
dawned on me that they were protecting their young behind their own bodies. A volley of shot-guns and Winchesters and one noble head fell flat on the water, another volley and the gander fell, then a wild skurrying, yelling, and shooting for some minutes resulted in the death of the two downlings.

"I could do nothing to stop them. I have trouble enough in matters that are my business and this they consider solely their own. It is nothing but kill, kill, kill every living thing they meet. One cannot blame them in general, since they live by hunting, and in this case they certainly did eat every bit of all four birds, even to their digestive organs with contents; but it seemed hard to have the devotion of the parents made their death trap when, after all, we were not in need of meat.

"July 20.--Rose at 4; had trouble on my hands at once. The Indians would not get up till 5 , so we did not get away till 6.20. Beaulieu was eviclently instructing the crew, for at the third breakfast all together (but perhaps 2) shouted out in English, 'Grub no good.'

"I walked over to them, asked who spoke; no one answered; so I reviewed the bargain, pointed out that I had given more than agreed, and added: 'I did not promise you beans, but will say now that if you work well I'll give you a bean feast once in a while.'

"They all said in various tongues and ways, 'That's all ri.' Beaulieu said it several times, and smiled and smiled. 
"If the mythical monster that dwells in the bottom of Great Slave Lake had reached up its long neck now and taken this same half-breed son of Belial, I should have said, 'Well done, good and faithful monster,' and the rest of our voyage would have been happier. Oh! what a lot of pother a beneficent little bean can make.

"At noon that day Billy announced that it was time to give me a lobstick; a spruce was selected on a slate island and trimmed to its proper style, then inscribed:

$$
\begin{aligned}
& \text { E. T. Seton } \\
& \text { E. A. Preble } \\
& \text { W. C. Loutit } \\
& 20 \text { July } \\
& 1907
\end{aligned}
$$

"Now I was in honour bound to treat the crew. I had neither the power nor the wish to give whiskey. Tobaceo was already provided, so I seized the opportunity of smoothing things by announcing a feast of beans, and this, there was good reason to believe, went far in the cause of peace.

"At 1.30 for the first time a fair breeze sprang up or rather lazily got up. Joyfully then we raised our mast and sail. The boys curled up to sleep, except Bcaulieu. He had his fiddle and now he proceeded to favour us with 'A Life on the Ocean Wave,' 'The Campbells are Coming,' ete., in a manner worthy of his social position and of his fiddle. When not in use this asthetic instrument (in its box) knocks about on deck or underfoot, among pots and pans, ex- 
posed in all weather; no one seems to fear it will be injured.

"At 7 the usual dead calm was restored. We rowed till we reached Et-then Island at 8, covering two miles more or 32 in all to-day. I was unwilling to

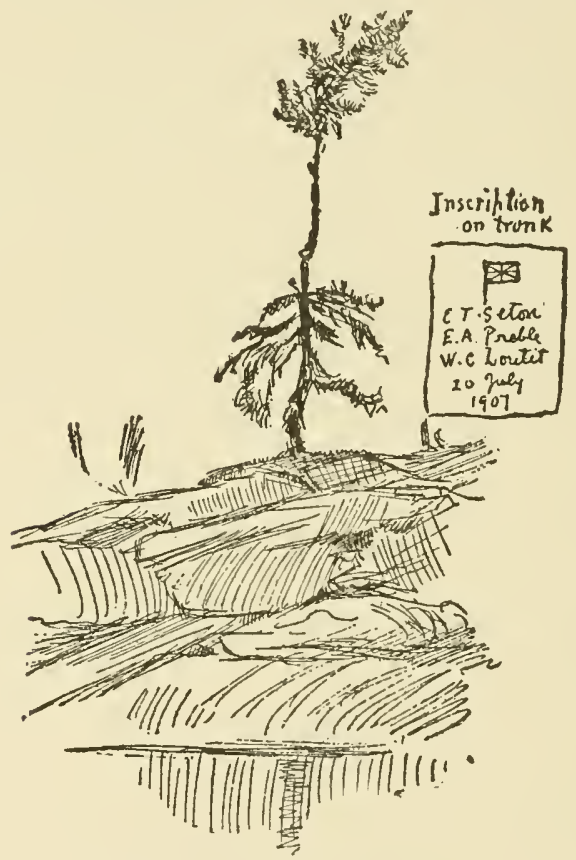

My Lobstick on a slate island, Great Slave Lake

stop now, but the boys said they would row all day Sunday if I would camp here, and then added, 'And if the wind rises to-night we'll go on.'

"At 10 o'clock I was already in bed for the night, though of course it was broad daylight. Preble had 
put out a line of mouse-traps, when the cry was raised by the Indians now eating their 7 th meal: 'Chim-palle! Hurra! Chilla quee!' ('Sailing wind! Hurra, boys!').

"The camp was all made, but after such a long calm a sailing wind was too good to miss. In 10 minutes every tent was torn down and bundled into the boat. At 10.10 we pulled out under a fine promising breeze; but alas! for its promise! at 10.30 the last vestige of it died away and we had to use the oars to make the nearest land, where we tied up at 11 P. Mr.

"That night old Weeso said to me, through Billy, the interpreter: "To-morrow is Sunday, therefore he would like to have a prayer-meeting after breakfast.'

"'Tell him,' I said, 'that I quite approve of his prayer-meeting, but also it must be understood that if the good Lord sends us a sailing wind in the morning that is His way of letting us know we should sail.'

"This sounded so logical that Weeso meekly said, 'All right.'

"Sure enough, the morning dawned with a wind and we got away after the regular sullen grumbling. About 10.20 the usual glassy calm set in and Weeso asked me for a piece of paper and a pencil. He wrote something in Chipewyan on the sheet I gave, then returned the pencil and resumed his pilotic stare at the horizon, for his post was at the rudder. At length he rolled the paper into a ball, and when I seemed not observing dropped it behind him overboard.

"What is the meaning of that, Billy?' I whispered. "'He's sending a prayer to Jesus for wind.' Half an hour afterward a strong head-wind sprang up, 
and Weeso was severely criticised for not specifying clearly what was wanted.

"There could be no question now about the propriety of landing. Old Weeso took all the Indians off to a rock, where, bareheaded and in line, they kneeled facing the east, and for half an hour he led them in prayer, making often the sign of the cross. The headwind died away as they came to the boat and again we resumed the weary rowing, a labour which all were supposed to share, but it did not need an expert to see that Beaulieu, Snuff, and Terchon merely dipped their oars and let them drift a while; the real rowing of that cumbrous old failure of a sailboat was done by Billy Loutit and Yum Freesay."

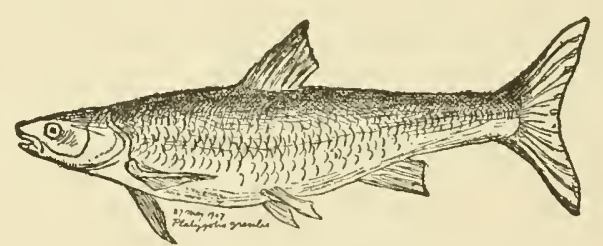

Platygobio gracilis 


\section{CHAPTER XXV}

\section{CROSSING THE LAKE-I'TS NA'TURAL HISTORY}

A LL day long here, as on the Nyarling, I busied myself with compass and sketch-book, making the field notes, slietches, and compass surveys from which my various maps were compiled; and Preble let no chance go by of noting the changing bird and plant life that told us we quit the Canadian fauna at Stony Island and now were in the Hudsonian zone.

This is the belt of dwindling trees, the last or northmost zone of the forest, and the spruce trees showed everywhere that they were living a life-long battle, growing and seeding, but dwarfed by frost and hardships. But sweet are the uses of adversity, and the stunted sprucelings were beautified, not uglified, by their troubles. I never before realised that a whole country could be such a series of charming little Japanese gardens, with tiny trees, tiny flowers, tiny fruits, and gorgeous oriental rugs upon the earth and rocks between.

I photographed one group of trees to illustrate their dainty elfish dwarfishmess, but realising that no one could guess the height without a scale, I took a second of the same with a small Indian sitting next it.

Weeso is a kind old soul; so far as I could see he took no part in the various seditions, but he was not 


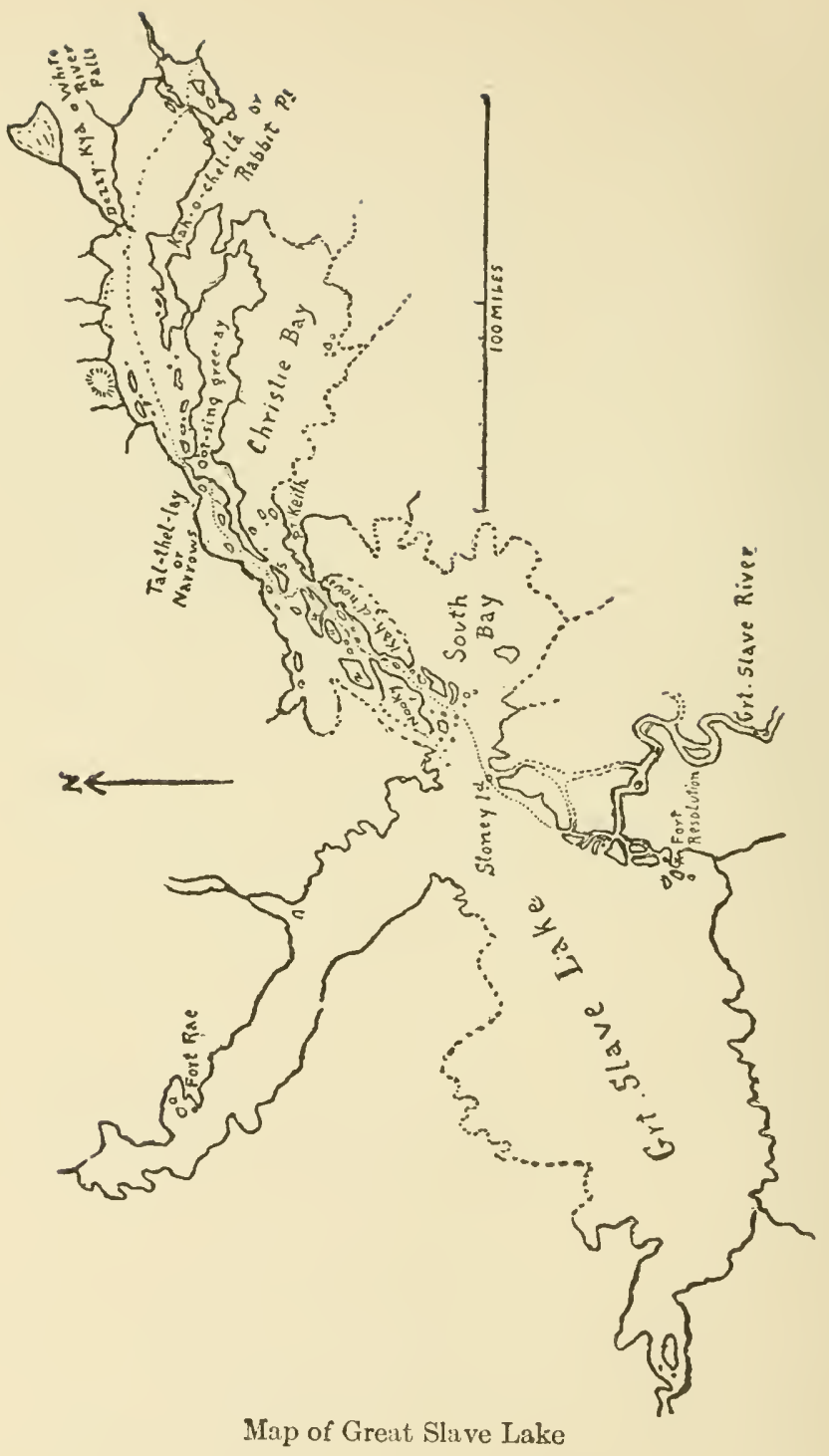




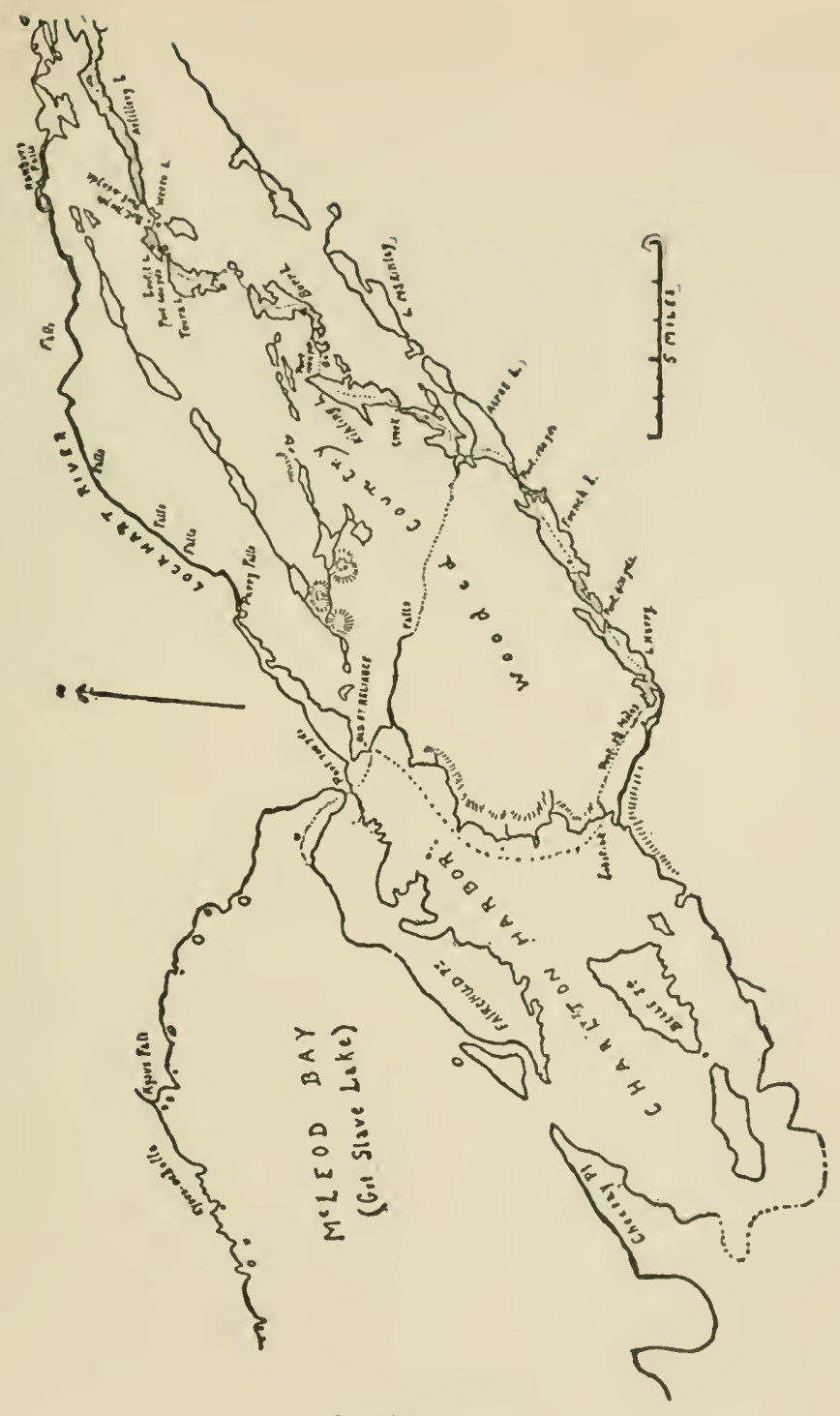

Pike's Portage

rounded chiefly on J. $W$, Tyrrell's mep of 1900 
an inspiring guide. One afternoon he did something that made a final wreck of my confidence. A thunderstorm was rumbling in the far east. Black clouds began travelling toward us; with a line of dark and troubled waters below, the faint breeze changed around

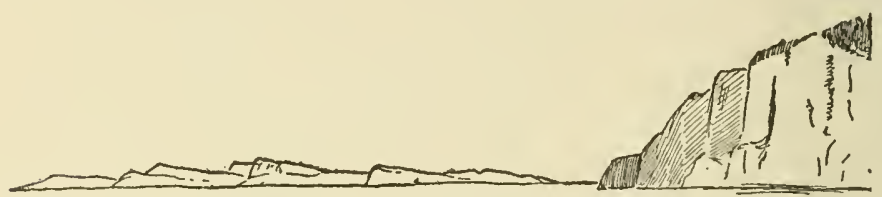

Oot-sing-gree-ay Island

Cliff on N. E. end of Et-then Island

and became a squall. Weeso looked scared and beckoned to Freesay, who came and took the helm. Nothing happened.

We were now running along the north shore of Etthen, where are to be seen the wonderful 1,200-foot cliffs described and figured by Captain George Back in 1834. They are glorious ramparts, wonderful in size and in colour, marvellous in their geological display.

Flying, and evidently nesting among the dizzy towers, were a few Barn-swallows and Phcebe-birds.

This cliff is repeated on Oot-sing-gree-ay, the next island, but there it is not on the water's edge. It gives a wonderful echo which the Indians (not to mention myself) played with, in childish fashion.

On Sunday, 21 July, we made a new record, 6 meals and 20 miles.

On July 22 we made only 7 meals and 11 miles and camped in the narrows Tal-thel-lay. These are a quarter of a mile wide and have a strong current run- 


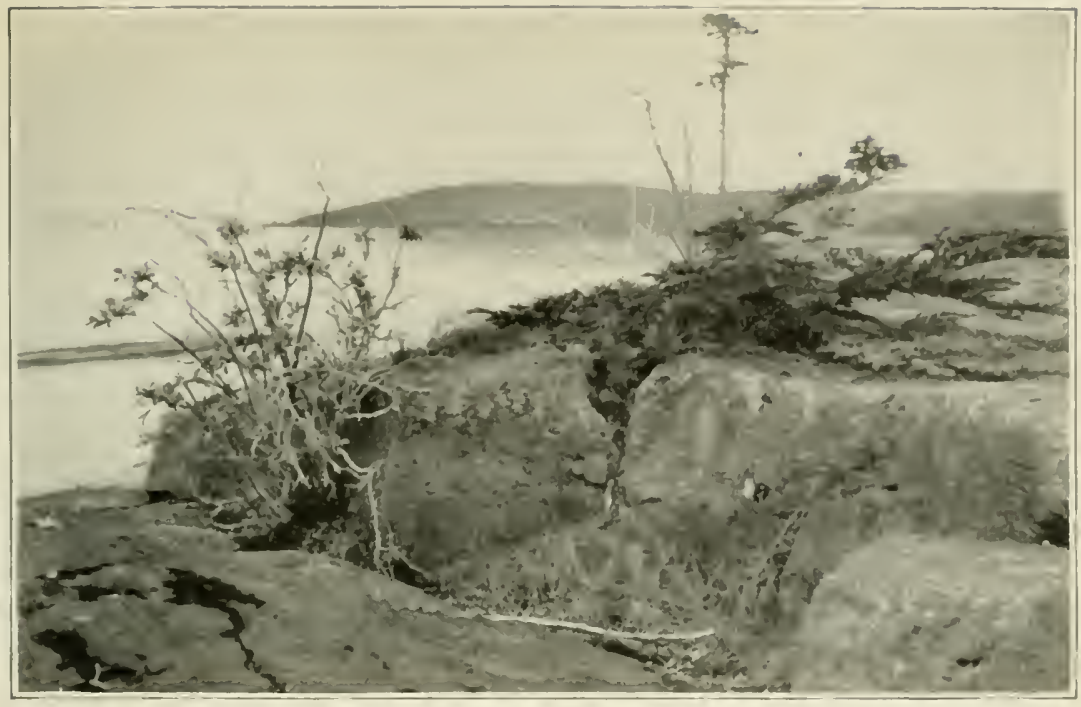

The Japanese landscipe about Great Slave Lake

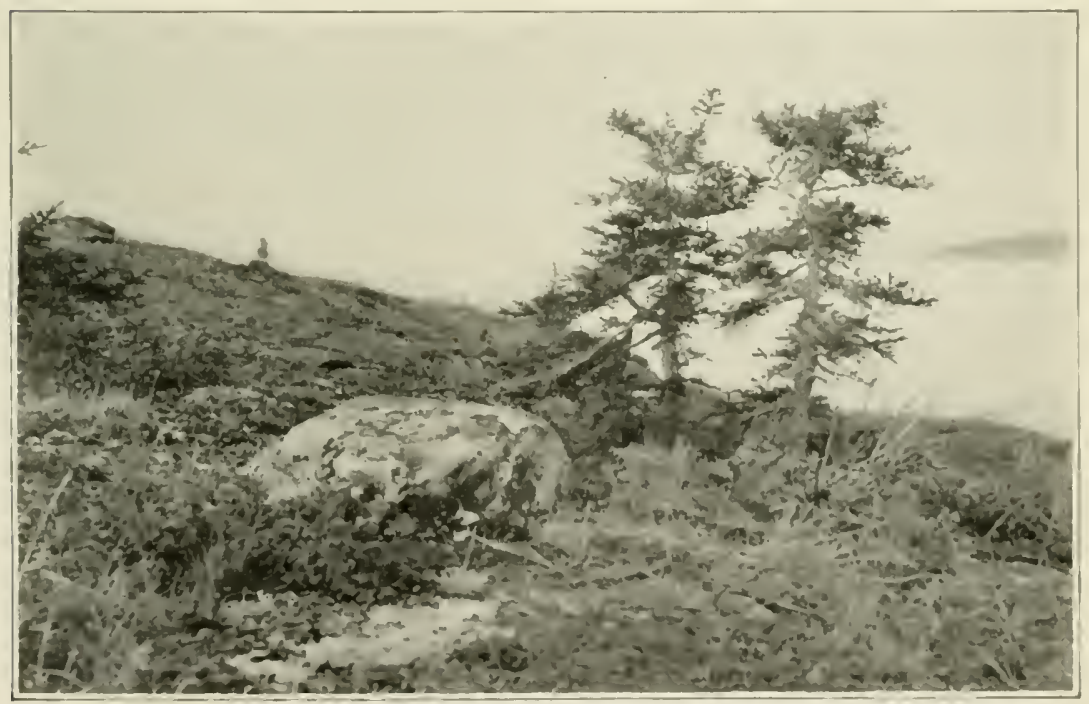

Dwarf spruce, about four feet high, on edge of the Barren-Grounds 

ning westerly. This is the place which Back says is a famous fishing ground and never freezes over, even in the hardest winters. Here, as at all points, I noted the Indian names, not only because they were appropriate, but in hopes of serving the next traveller. I found an unexpected difficulty in writing them down, viz.: no matter how I pronounced them, old Weeso and Freesay, my informants, would say, "Yes, that is right." This, I learned, was out of politeness; no matter how you mispronounce their words it is good form to say, "That's it; now you have it exactly."

The Indians were anxious to put out a net overnight here, as they could count on getting a few Whitefish; so we camped at 5.15. It is difficult to convey to an outsider the charm of the word "whitefish." Any northerner will tell you that it is the only fish that is perfect human food, the only food that man or dog never wearies of, the only lake food that conveys no disorder no matter how long or freely it is used. It is so delicious and nourishing that there is no fish in the world that ean even come second to it. It is as far superior in all food qualities to the finest Salmon or Trout as a first-prize, gold-medalled, nut-fed thoroughbred Sussex bacon-hog is to the roughest, toughest, boniest old razor-backed land-pike that ever ranged the woods of Arkansas.

That night the net yielded 3 Whitefish and 3 Trout. The latter, being 4 to 8 pounds each, would have been reckoned great prizes in any other country, but now all attention was on the Whitefish. They certainly were radiantly white, celestial in color; their backs 
were a dull frosted silver, with here and there a small electric lamp behind the scales to make its jewels sparkle. The lamps alternated with opals increased on the side; the bellies were of a blazing mother-ofpearl. It would be hard to imagine a less imaginative name than "white" fish for such a shining, burning opalescence. Indian names are usually descriptive,

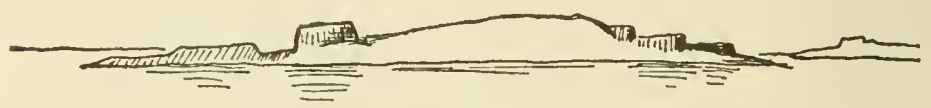

Tha-sess San-dou-ay two miles away (Swallow Island)

but their name for this is simply "The Fish." All others are mere dilutes and cheap imitations, but the Coregonus is at all times and par excellence "The Fish."

Nevertheless, in looking at it I could not help feeling that this is the fat swine, or the beef Durham of its kind. The head, gills, fins, tail, vital organs and bones all were reduced to a minimum and the meat parts enlarged and solidified, as though they were the product of ages of careful breeding by man to produce a perfect food fish, a breeding that has been crowned with the crown of absolute success.

The Indians know, for the best of reasons, the just value of every native food. When Rabbits abound they live on them but do not prosper; they call it "starving on rabbits." When Caribou meat is plenty they eat it, but crave flour. When Moose is at hand they eat it, and are strong. When Jack-fish, Sucker, Conies, and Trout are there, they take them as a variant; but on Whitefish, as on Moose, they can live with- 
out loathing, and be strong. The Indian who has his scaffold hung with Whitefish when winter comes, is accounted rich.

"And what," says the pessimist, "is the fly in all this precious ointment?" Alas! It is not a game fish; it will not take bait, spoon, or fly, and its finest properties vanish in a few hours after capture.

The Whitefish served in the marble palaces of other lands is as mere clish-water to champagne, when compared with the three times purified and ten times intensified dazzling silver Coregonus as it is landed on the bleak shores of those far-away icy lakes. So I could not say 'No' to the Indian boys when they wanted to wait here, the last point at which they could be sure of a catch.

That night (22d July) five canoes and two York boats of Indians landed at the narrows. These were Dogribs of Chief Vital's band; all told they numbered about thirty men, women, and children; with them were twenty-odd dogs, which immediately began to make trouble. When one is in Texas the topic of conversation is, "How are the cattle?" in the Klondike, "How is your claim panning out?" and in New York, "How are you getting on with your novel?" On Great Slave Lake you say, "Where are the Caribou?" The Inclians could not tell; they had seen none for weeks, but there was still much ice in the east end of the lake which kept them from investigating. They had plenty of dried Caribou meat but were out of tea and tobaceo. I had come prepared for this sort of situation, and soon we had a fine stock of dried venison. 
These were the Indians whose abandoned dogs made so much trouble for us in the days that followed.

At 4 P. м. of $23 \mathrm{~d}$ of July we were stopped by a long narrow floe of broken ice. Without consulting me the crew made for the shore.

It seemed they were full of fears: "What if they should get caught in that floe, and drift around for days? What if a wind should arise (it had been glassy calm for a week)? What if they could not get back?" ete., etc.

Preble and I climbed a hill for a view. The floe was but half a mile wide, very loose, with frequent lanes.

"Preble, is there any reason why we should not push through this floe using poles to move the cakes?"

"None whatever."

On descending, however, I found the boys preparing to camp for "a couple of days," while the ice melted or drifted away somewhere.

So I said, "You get right into this boat now and push off; we can easily work our way through." They made no reply, simply looked sulkier than ever, and proceeded to start a fire for meal No. 5 .

"Weeso," I said, "get into your place and tell your men to follow."

The old man looked worried and did nothing. He wanted to do right, but he was in awe of his crew.

Then did I remember how John MacDonald settled the rebellion on the river.

"Get in there," I said to Preble and Billy. "Come on, Weeso." We four jumped into the boat and proceeded to push off with all the supplies. 

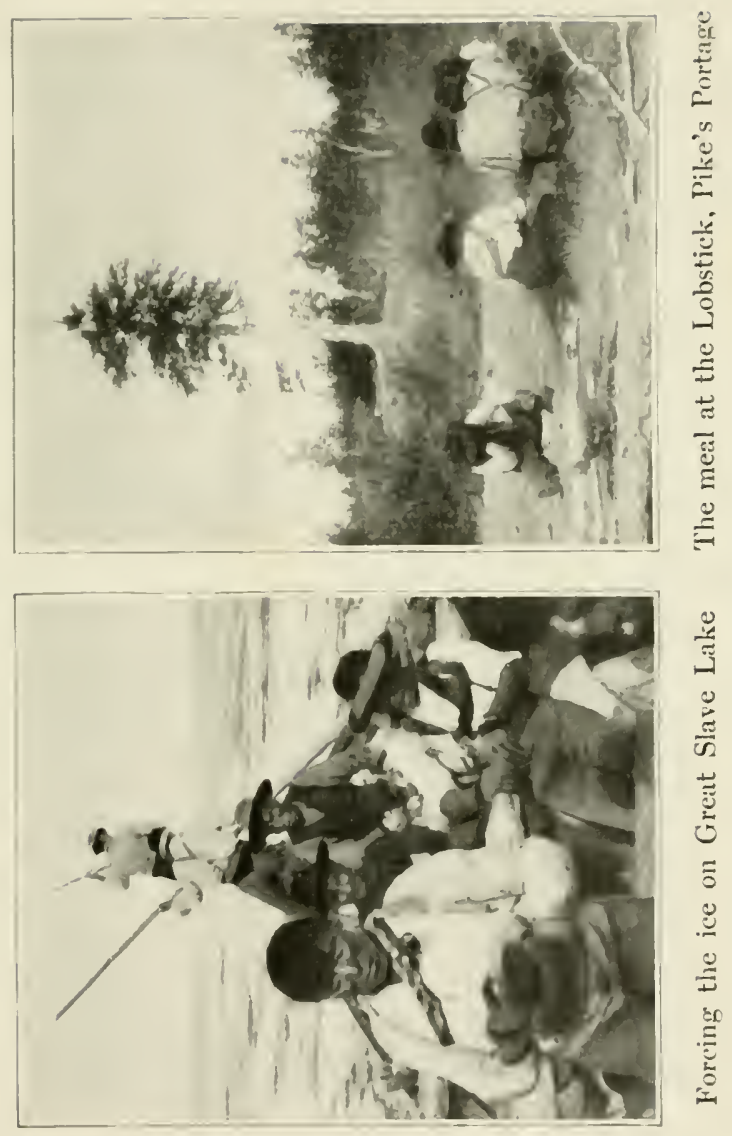

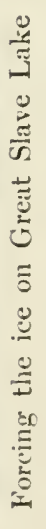



Authorities differ as to the time it took for the crew to make up their minds. Two seconds and eleven seconds are perhaps the extremes of estimate. They came jumping aboard as fast as they could.

We attacked the floe, each with a lodge-pole; that is, Billy and Preble did in the bow, while Freesay and I did at the rear; and in thirty-five minutes we had pushed through and were sailing the open sea.

The next day we had the same scene repeated with less intensity, in this case because Freesay sided with me. What would I not give to have had a crew of white men. A couple of stout Norwegian sailors would have done far better than this whole outfit of reds.

When we stopped for supper No. 1 a tiny thimbleful of down on two pink matches ran past, and at once the mother, a Pectweet, came running in distress to save lier young. The brave Beaulieu fearlessly seized a big stick and ran to kill the little one. I shouted out, "Stop that," in tones that implied that I owned the heaven, the earth, the sea, and all that in them is, but could not have saved the downling had it not leaped into the water and dived out of sight. It came up two fect away and swam to a rock of safety, where it bobbed its latter end toward its adversaries and the open sea in turn.

I never before knew that they could dive.

About eight o'clock we began to look for a good place to camp and make meal No. 6. But the islands where usually we found refuge from the dogs were without wood, and the shores were too rugged and steep or had no dry timber, so we kept going on. After trying one 
or two places the Indians said it was only a mile to Indian Mountain River (Der-sheth Tessy), where was a camp of their friends. I was always glad of a reason for pushing on, so away we went. My crew seized their rifles and fired to let their village know we were coming. The camp came quickly into view, and volley after volley was fired and returned.

These Indians are extremely poor and the shots cost 5 and 6 cents each. So this demonstration totalled up about $\$ 2.00$.

As we drew near the village of lodges the populace lined up on shore, and then our boys whispered, "Some white men." What a peculiar thrill it gave me! I had seen nothing but Indians along the route so far and expected nothing else. But here were some of my own people, folk with whom I could talk. They proved to be my American friend from Smith Landing, he whose hand I had lanced, and his companion, a young Englishman, who was here with him prospecting for gold and copper. "I'm all right now," he said, and held up the hand with my mark on it, and our greeting was that of white men meeting among strangers in a far foreign land.

As soon as we were ashore a number of Indians came to offer meat for tobacco. They seemed a lot of tobacco-maniacs. "Tzel-twee" at any price they must have. Food they could do without for a long time, but life without smoke was intolerable; and they offered their whole dried product of two Caribou, concentrated, nourishing food enough to last a family many days, in exchange for half a pound of nasty, stinking, poisonous tobacco. 
Two weeks hence, they say, these hills will be alive with Caribou; alas! for them, it proved a wholly erroneous forecast.

Y.'s guide is Sousi King Beaulieu (for pedigree, see Warburton Pike); he knows all this country well and gave us much information about the route. He says that this year the Caribou cows went north as usual, but the bulls did not. The season was so late they did not think it worth while; they are abundant yet at Artillery Lake.

He recognised me as the medicine man, and took an early opportunity of telling me what a pain he had. Just where, he was not sure, but it was hard to bear; he would like some sort of a pain-killer. Evidently he craved a general exhilarator.

Next morning we got away at $7 \mathrm{~A}$. M. after the usual painful scene about getting up in the middle of the night, which was absurd, as there was no night.

Next afternoon we passed the Great White Fall at the mouth of Hoar Frost River; the Indians eall it Dezza Kya. If this is the Beverly Falls of Back, his illustrator was without information; the published picture bears not the slightest resemblance to it.

At three in the afternoon of July $27 \mathrm{th}$, the twelfth clay after we had set out on the "three or four day run" from Resolution, this exasperating and seemingly interminable voyage really did end, and we thankfully' beached our York boat at the famous lobstick that marks the landing of Pike's Portage. 


\section{CHAPTER XXVI}

\section{THE LYNX AT BAY}

ONE of the few rewarding episodes of this voyage took place on the last morning, July 27. We were half a mile from Charleston Harbour when one of the Indians said "Cheesay" (Lynx) and pointed to the south shore. There, on a bare point a quarter mile away, we saw a large Lynx walking quietly along. Every oar was dropped and every rifle seized, of course, to repeat the same old scene; probably it would have made no difference to the Lynx, but I called out:" Hold on there! I'm going after that Cheesay."

Calling my two reliables, Preble and Billy, we set out in the canoe, armed, respectively, with a shotgun, a club, and a camera.

When we landed the Lynx was gone. We hastily made a skirmishing line in the wood where the point joined the mainland, but saw no sign of him, so concluded that he must be hiding on the point. Billy took the right shore, Preble the left, I kept the middle. Then we marched toward the point but saw nothing. There were no bushes except a low thicket of spruce, some 20 feet across and 3 or 4 feet high. This was too dense to penetrate standing, so I lay down on my breast and proceeded to crawl in under the low boughs. I had not gone six feet before a savage growl warned me 
back, and there, just alhead, crouched the Lynx. He glared angrily, then rose up, and I saw, with a little shock, that he had been crouching on the body of another Lynx, cating it. Photography was impossible there, so I took a stick and poked at him; he growled, struck at the stick, but went out, then dashed across the open for the woods. As he went I got photograph No. 1. Now I saw the incredible wonder I had heard of-a good runner can outrun a Lynx. Preble was a sprinter, and before the timber 200 yards off was reached that Lynx was headed and turned; and Preble and Billy were driving him back into my studio. He made several dashes to escape, but was out-manœuvred and driven onto the far point, where he was really between the devils and the deep sea. Here he faced about at bay, growling furiously, thumping his little bobtail from side to side, and pretending he was going to spring on us. I took photo No. 2 at 25 yards. He certainly did look very fieree, but I thought I knew the creature, as well as the men who were backing me. I retired, put a new film in place, and said:

"Now, Preble, I'm going to walk up to that Lynx and get a close photo. If he jumps for me, and he may, there is nothing can save my beauty but you and that gun."

Preble with characteristic loquacity says, "Go ahead."

Then I stopped and began slowly approaching the desperate ereature we held at bay. His eyes were glaring green, his ears were back, his small bobtail kept twitching from side to side, and his growls grew 
harder and hissier, as I neared him. At 15 feet he gathered his legs under him as for a spring, and I pressed the button getting, No. 3 .

Then did the demon of ambition enter into my heart and lead me into peril. That Lynx at bay was starving and desperate. He might spring at me, but I believed that if he did he never would reach me alive. I knew my man-this nerved me-and I said to him: "I'm not satisfied; I want him to fill the finder. Are you ready?"

"Yep."

So I crouched lower and came still nearer, and at 12 feet made No. 4 . For some strange reason, now the Lynx seemed less angry than he had been.

"He didn't fill the finder; I'll try again," was my next. Then on my knees I crawled up, watching the finder till it was full of Lynx. I glanced at the beast; he was but 8 feet away. I focused and fired.

And now, oh, wonder! that Lynx no longer seemed annoyed; he had ceased growling and simply looked bored.

Seeing it was over, Preble says, "Now where does he go? To the Museum?"

"No, indeed!" was the reply. "He surely has earned his keep; turn him loose. It's back to the woods for him." We stood aside; he saw his chance and dashed for the tall timber. As he went I fired the last film, getting No. 6; and so far as I know that Lynx is alive and well and going yet. 

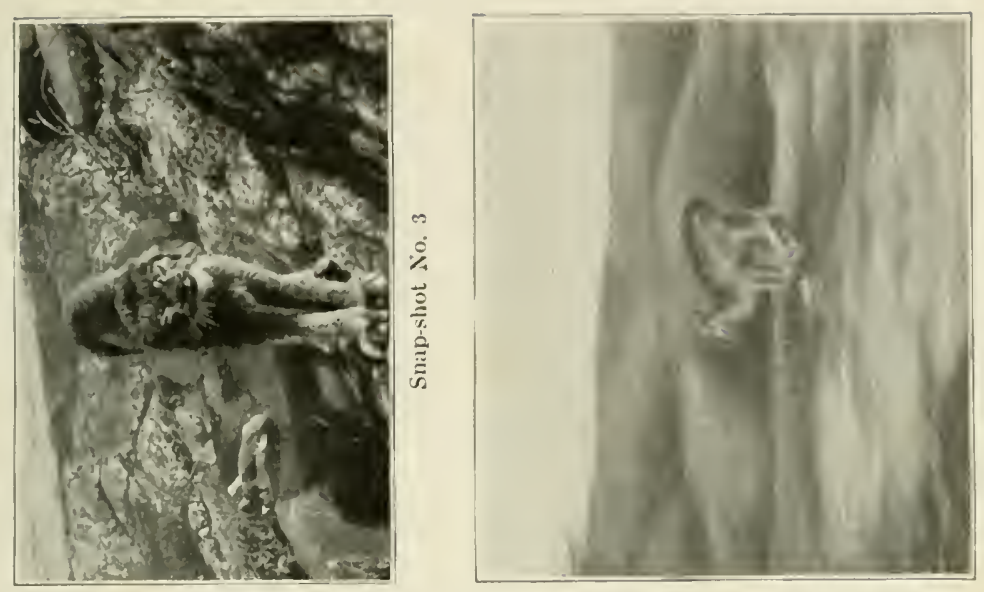

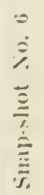
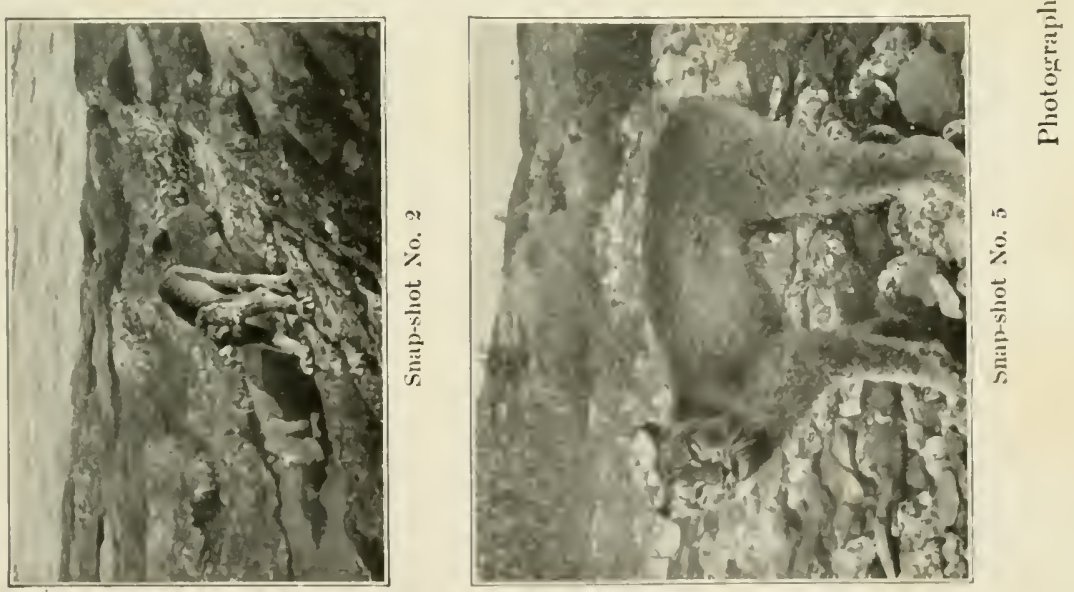



\section{CHAPTER XXVII}

\section{TIIE LAST OF' 'THAT INDIAN CREW}

Carved on the lobstick of the Landing were many names famous in the annals of this region, Pike, Maltern, McKinley, Munn, Tyrrel among them. All about were evidences of an ancient and modern camplodge poles ready for the covers, relies and wrecks of all sorts, fragments of canoes and sleds, and the inevitable stray Indian dog.

First we made a meal, of course; then I explained to the crew that I wanted all the stuff carried over the portage, $3 \frac{1}{4}$ miles, to the first lake. At once there was a row; I was used to that. There had been a row cvery morning over getting up, and one or two each day about other details. Now the evil face of Beaulieu showed that his tongue was at work again. But I knew my lesson.

"You were brought to man the boat and bring my stuff over this portage. So do it and start right now." They started 31 miles with heary loads, very heavy labour I must admit, back then in four hours to make another meal, and eamp.

Next morning another row before they would get up and take each another load. But canoe and everything were over by noon. And then eame the final scene. 
In all the quarrels and mutinies, old Weeso had been faithful to me. Freesay had said little or nothing, and had always worked well and cheerfully. Weeso was old and weak, Freesay young and strong, and therefore he was the one for our canoe. I decided it would pay to subsidise Weeso to resign in favour of the younger man. But, to be sure, first asked Freesay if he would like to come with me to the land of the Musk-ox. His answer was short and final, "Yes," but he could not, as his uncle had told him not to go beyond this portage. That settled it. The childlike obedience to their elders is admirable, but embarrassing at times.

So Weeso went after all, and we got very well acquainted on that long trip. He was a nice old chap. He always meant well; grinned so happily when he was praised, and looked so glum when he was scolded. There was little of the latter to do; so far as he knew, ne did his best, and it is a pleasure now to conjure up his face and ways. His cheery voice, at my tent door every morning, was the signal that Billy had the breakfast within ten minutes of ready.

"Okimow, To" (Chief, here is water), he would say as he set down the water for my bath and wondered what in the name of common sense should make the Okimow need washing every morning. He himself was of a cleaner kind, having needed no bath during the whole term of our acquaintance.

There were two peculiarities of the old man that should make him a good guide for the next party going northward. First, he never forgot a place once he 
had been there, and could afterward go to it direct from any other place. Second, he had the most wonderful nose for firewood; no keen-eyed raven or starving wolf could go more surely to a marrow-bone in cache, than could Weeso to the little sticks in far away hollows or granite clefts. Again and again, when we landed on the level or rocky shore and all hands set out to pick up the few pencil-thick stems of creeping birch, roots of annual plants, or wisps of grass to boil the kettle, old Weeso would wander off by himself and in five minutes return with an armful of the most amazingly acceptable firewood conjured out of the absolutely timberless, unpromising waste. I never yet saw the camp where he could not find wood. So he proved good stuff; I was glad we had brought him along.

And I was equally glad now to say good-bye to the rest of the erew. I gave them provisions for a week, added a boiling of beans, and finally the wonderful paper in which I stated the days they had worked for me, and the lind of service they had rendered, commended Freesay, and told the truth about Beaulieu.

"Dat paper tell about me," said that worthy suspiciously.

"Yes," I said, "and about the others; and it tells Harding to pay you as agreed."

We all shook hands and parted. I have not seen them since, nor do I wish to meet any of them again, except Freesay.

My advice to the next traveller would be: get white men for the trip and one Indian for guide. When 
alone they are manageable, and some of them, as seen already, are quite satisfactory, but the more of them the worse. 'They combine, as Pike says, the meanest qualities of a savage and an unscrupulous moneylender. The worst one in the crowd seems most readily followed by the others. 


\section{CHAP'TER XXVIII}

\section{GEOLOGICAL FORCES AT WORK}

IT seems to me that never before have I seen the geological forces of nature so obviously at work. Elsewhere I have seen great valleys, cliffs, islands, etc., held on good evidence to be the results of such and such powers formerly very active; but here on the Athabaska I saw daily evidence of these powers in full blast, ripping, tearing, reconstructing, while we looked on.

All the way down the river we saw the process of undermining the bank, tearing down the trees to whirl them again on distant northern shores, thus widening the river channel

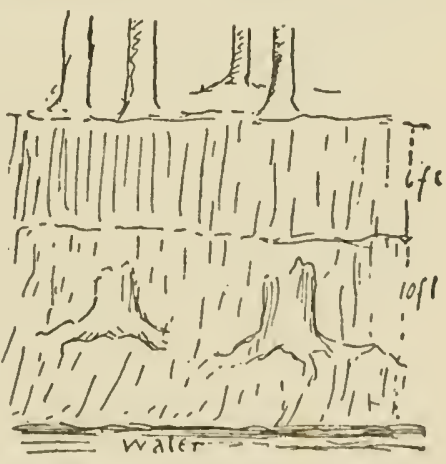

Bank exposing different levels, etc. showing how various Anods and ice plowings lase changed the level within recent rears until too wide for its normal flood, which in time drops into a deeper restricted channel, in the wide summer waste of gravel and sand.

Ten thousand landslides take place every spring, contributing their tons of mud to the millions that the river is deporting to the broad catch basins called the Athabaska and Great Slave Lakes. 
Many a tree has happened to stand on the very crack that is the upmost limit of the slide and has in consequence been ripped in two.

Many an island is wiped out and many a one made in these annual floods. Again and again we saw the evidence of some island, continued long enough to raise

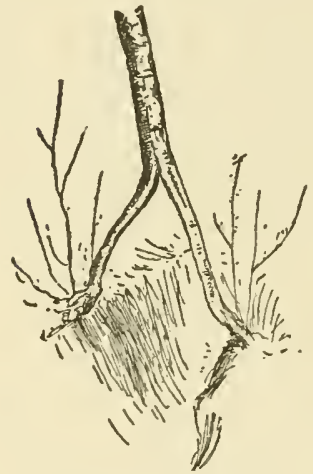

A $4 \frac{1}{2}$ inch birch split by a landslide. This is a common accident

a spruce forest, suddenly receive a 6 -foot contribution from its erratic mother; so the trees were buried to the arm-pits.

Many times I saw where some frightful jam of ice had planed off all the trees; then a deep overwhelming layer of mud had buried the stumps and grown in time a new spruce forest. Now the mighty erratic river was tearing all this work away again, exposing all its history.

In the delta of the Slave, near Fort Resolution, we saw the plan of delta work. Millions of tons of mud poured into the deep translucent lake have filled it for miles, so that it is scarcely deep enough to float a canoe; thousands of huge trees, stolen from the upper forest, are here stranded as wing-dams that check the current and hold more mud. Rushes grow on this and catch more mud. Then the willows bind it more, and the sawing down of the outlet into the Mackenzie results in all this mud being left dry land.

This is the process that has made all the lowlands at the mouth of Great Slave and Athabaska Rivers. 
And the lines of tree trunks to-day, preparing for the next constructive annexation of the lake, are so regular that one's first thought is that this is the work of man. But these are things that my sketches and photographs will show better than words.

When later we got onto the treeless Barrens or Tundra, the process was equally evident, though at this time dormant, and the chicf agent was not running water, but the giant Jack Frost.

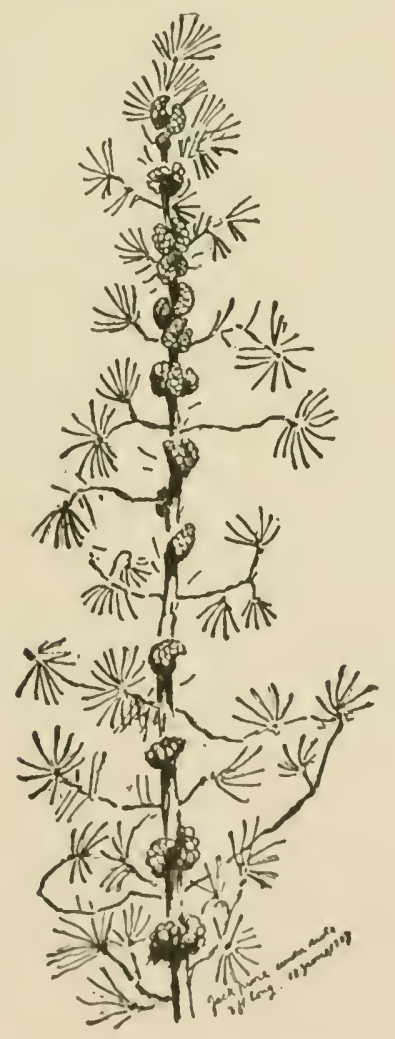




\section{CHAPTER XXIX}

\section{PIKE'S PORTAGE}

PART of my plan was to leave a provision cache every hundred miles, with enough food to carry us 200 miles, and thus cover the possibility of considerable loss. I had left supplies at Chipewyan, Smith, and Resolution, but these were settlements; now we were pushing off into the absolute wilderness, where it was unlikely we should see any human beings but ourselves. Now, incleed, we were facing all primitive conditions. Other travellers have made similar plans for food stores, but there are three deadly enemies to a cache-weather, ravens, and wolverines. I was prepared for all three. Water-proof leatheroid cases were to turn the storm, dancing tins and lines will scare the ravens, and each cache tree was made unclimbable to Wolverines by the addition of a necklace of charms in the form of large fish-hooks, all nailed on with points downward. This idea, borrowed from Tyrrell, has always proved a success; and not one of our caches was touched or injured.

Tyrrell has done much for this region; his name will ever be linked with its geography and history. His map of the portage was a godsend, for now we found that our guide had been here only once, and that when he was a child, with many resultant lapses of memory and doubts about the trail. My only wonder was that he remembered as much as he did. 


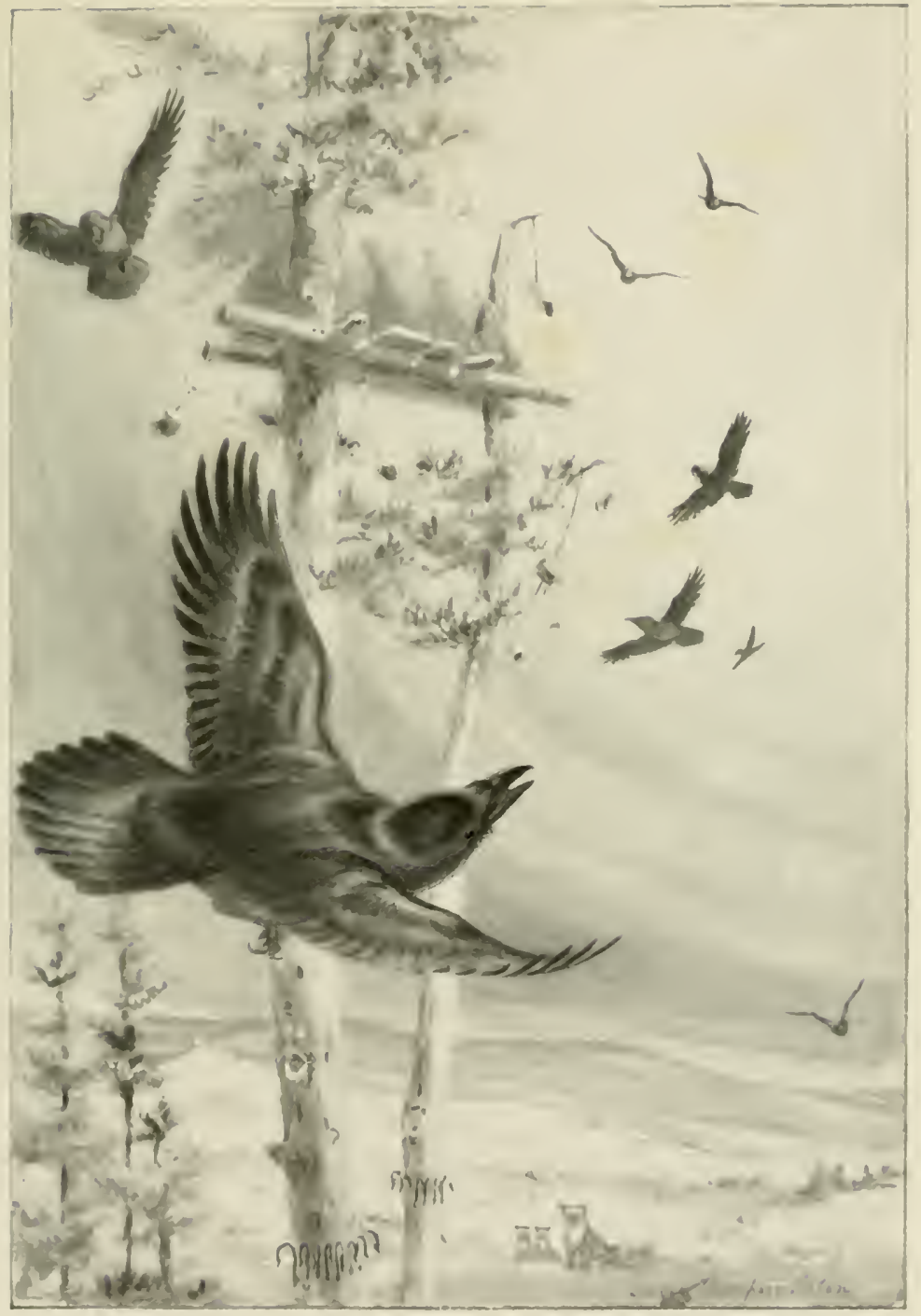

The Deathbirds, the Storm, and the Wolverine 

Here we had a sudden and unexpeeted onset of black flies; they appeared for the first time in numbers, and attacked us with a ferocity that made the mosquitoes seem like a lot of baby butterflies in comparison. However, much as we may dislike the latter, they at least do not poison us or convey disease (as yet), and are repelled by thick clothing. The black flies attack us like some awful pestilence walking in darkness, crawling in and foreing themselves under our clothing, stinging and poisoning as they go. They' are, of course, worst near the openings in our armour, that is necks, wrists, and ankles. Soon each of us had a neck like an old fighting bull walrus; cnormously swollen, corrugated with bloats and wrinkles, blotehed, bumpy, and bloody, as disgusting as it was painful. All too closely it simulated the ravages of some frightful disease, and for a night or two the torture of this itching fire kept me from slecping. Three days, fortunately, ended the black fly reign, and left us with a deeper sympathy for the poor Egyptians who on account of their own or some other bodies' sins were the victims of "plagues of flies."

But there was something in the camp that amply offset these annoyances; this was a spirit of kindness and confidence. Old Weeso was smiling and happy, ready at all times to do his best; his blundering albout the way was not surprising, all things considered, but his mistakes did not matter; sinee I had Tyrrell's admirable maps. Billy, sturdy, strong, reliable, never needed to be called twice in the morning. No matter what the hour, he was up at once and cooking the break- 
fast in the best of style, for an A 1 cook he was. And when it came to the portages he would shoulder his 200 or 250 pounds each time. Preble combined the mental force of the educated white man with the brawn of the savage, and although not supposed to do it, he took the same sort of loads as Billy did. Mine, for the best of reasons, were small, and consisted chiefly of the guns, cameras, and breakables, or occasionally, while they were transporting the heary stuff, I acted as cook. But all were literally and figuratively in the same boat, all paddled all day, ate the same food, worked the same hours, and imbued with the same spirit were eager to reach the same far goal. From this on the trip was ideal.

We were $3 \frac{1}{2}$ days covering the 8 small lakes and 9 portages (30 miles) that lie between the two great highways, Great Slave Lake and Artillery Lake; and camped on the shore of the latter on the night of July 31 .

Two of these 9 lakes had not been named by the original explorers. I therefore exercised my privilege and named them, respectively, "Loutit" and "Weeso," in honour of my men.

The country here is cut up on every side with caribou trails; deep worn like the buffalo trails on the plains, with occasional horns and bones; these, however, are not so plentiful as were the relics of the Buffalo. This, it proved, was because the Caribou go far north at horn-dropping time, and they have practically no bones that the Wolves cannot crush with their teeth.

Although old tracks were myriad-many, there were no new ones. Weeso said, however, "In about four 
day's the shores of this lake will be alive with Caribou." It will show the erratic nature of these animals when I say that the old man was all wrong; they did not appear there in numbers until many weeks later, probably not for two months.

Here, at the foot of Artillery Lake, we were near the last of the timber, and, strange to say, we found some trees of remarkably large growth. One, a tamarac, was the largest and last seen; the other, a sprucePike's Lobstick-was 55 inches in girth, 1 foot from the ground.

At this camp Weeso complained that he was feeling very sick; had pains in his back. I could not make out what was the matter with him, but Billy said sagaciously, "I think if you give him any kind of a pill he will be all right. It doesn't matter what, so long as it's a pill."

Of course "cathartic" is good blind play in case of doubt. He got a big, fierce rhubarb, and all went well. 


\section{CHAPTER XXX}

\section{CARIBOU-LAND AT LAST}

ON the morning of August 1 we launched on Artillery Lake, feeling, for the tenth time, that now we really were on the crowning stretch of our journey, that at last we were entering the land of the Caribou.

Over the deep, tranquil waters of the lake we went, scanning the painted shores with their dwindling remnants of forest. There is something inspiring about the profundity of transparency in these lakes, where they are 15 feet deep their bottoms are no more obscured than in an ordinary eastern brook at 6 inches. On looking down into the far-below world, one gets the sensation of flight as one skims overhead in the swift canoe. And how swift that elegant canoe was in a clear run I was only now finding out. All my previous estimates had been too low. Here I had the absolute gauge of Tyrrell's maps and found that we four paddling could send her, not $3 \frac{1}{2}$, but $4 \frac{1}{2}$ or 5 miles an hour, with a possibility of 6 when we made an effort. As we spun along the south-east coast of the lake, the country grew less rugged; the continuous steep granite hills were replaced by lower buttes with long grassy plains between; and as I took them in, I marvelled at their name-the Barrens; bare of trees, yes, but the plains were covered with rich, rank grass, more like New 


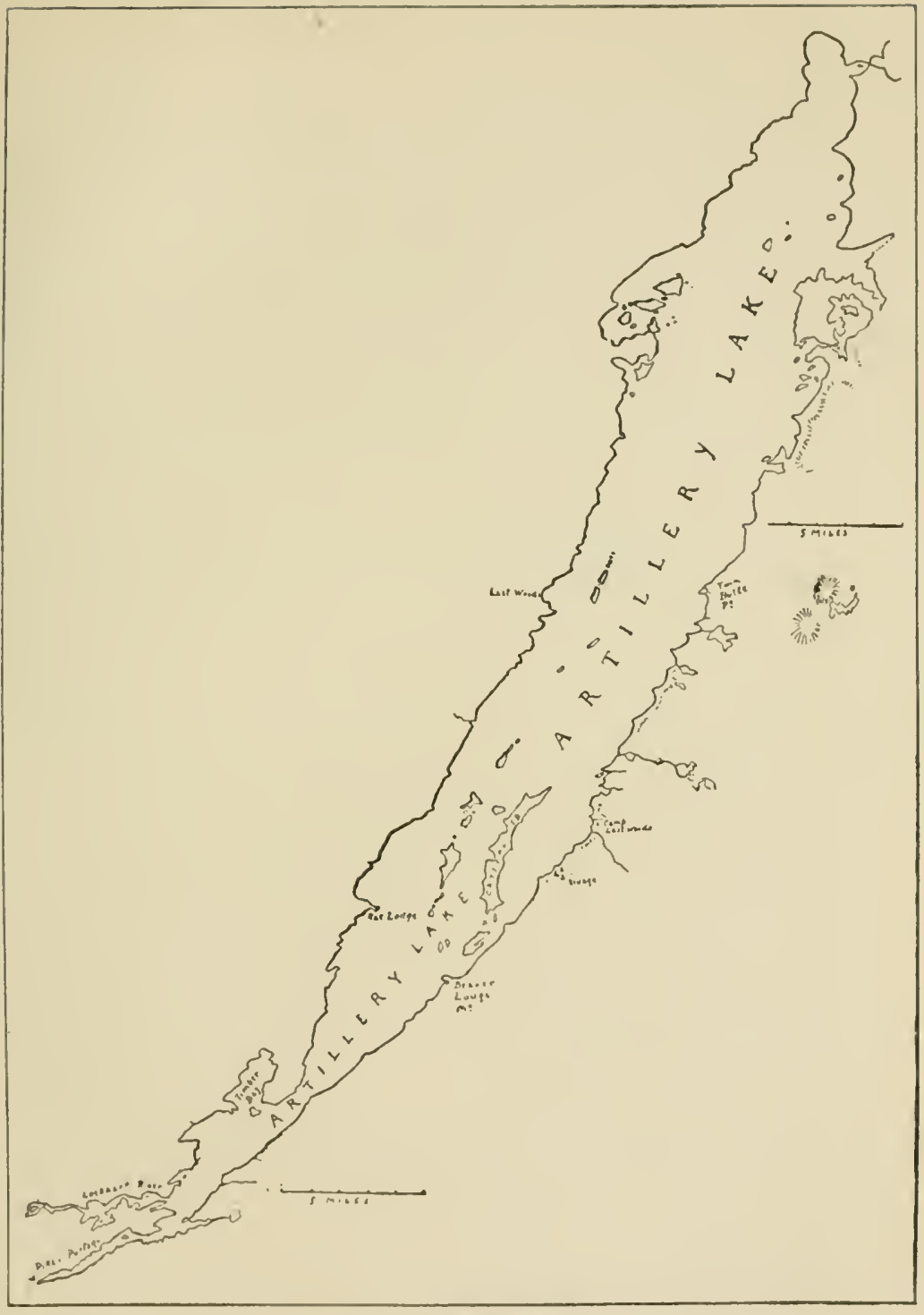

Artillery Lake

younded ihictly od J, W. Tyirell's uap of 1900 
England meadows. There were stretches where the herbage was rank as on the Indiana prairies, and the average pasture of the bleaker parts was better than the best of central Wyoming. A cattleman of the West would think himself made if he could be sure of such pastures on his range, yet these are the Barren Grounds.

At 3 we passed the splendid landmark of Beaver Lodge Mountain. Its rosy-red granite cliffs contrast

Beaver Lodge Mountain. Aug. 7, 1907

wonderfully with its emerald cap of verdant grass and mosses, that cover it in tropical luxuriance, and the rippling lake about it was of Mediterranean hues.

We covered the last 9 miles in 1 hour and 53 minutes, passed the deserted Indian village, and landed at Last Woods by 8.30 P. M.

The edge of the timber is the dividing line between the Hudsonian and the Arctic zones. It is the beginning of the country we had come to see; we were now in the land of the Caribou.

At this point we were prepared to spend several days, leave a cache, gather a bundle of choice firewood, then enter on the treeless plains.

That night it stormed; all were tired; there was no reason to bestir ourselves; it was 10 when we arose. Half an hour later Billy came to my tent and said, "Mr. Seton, here's some deer." I rushed to the door, 


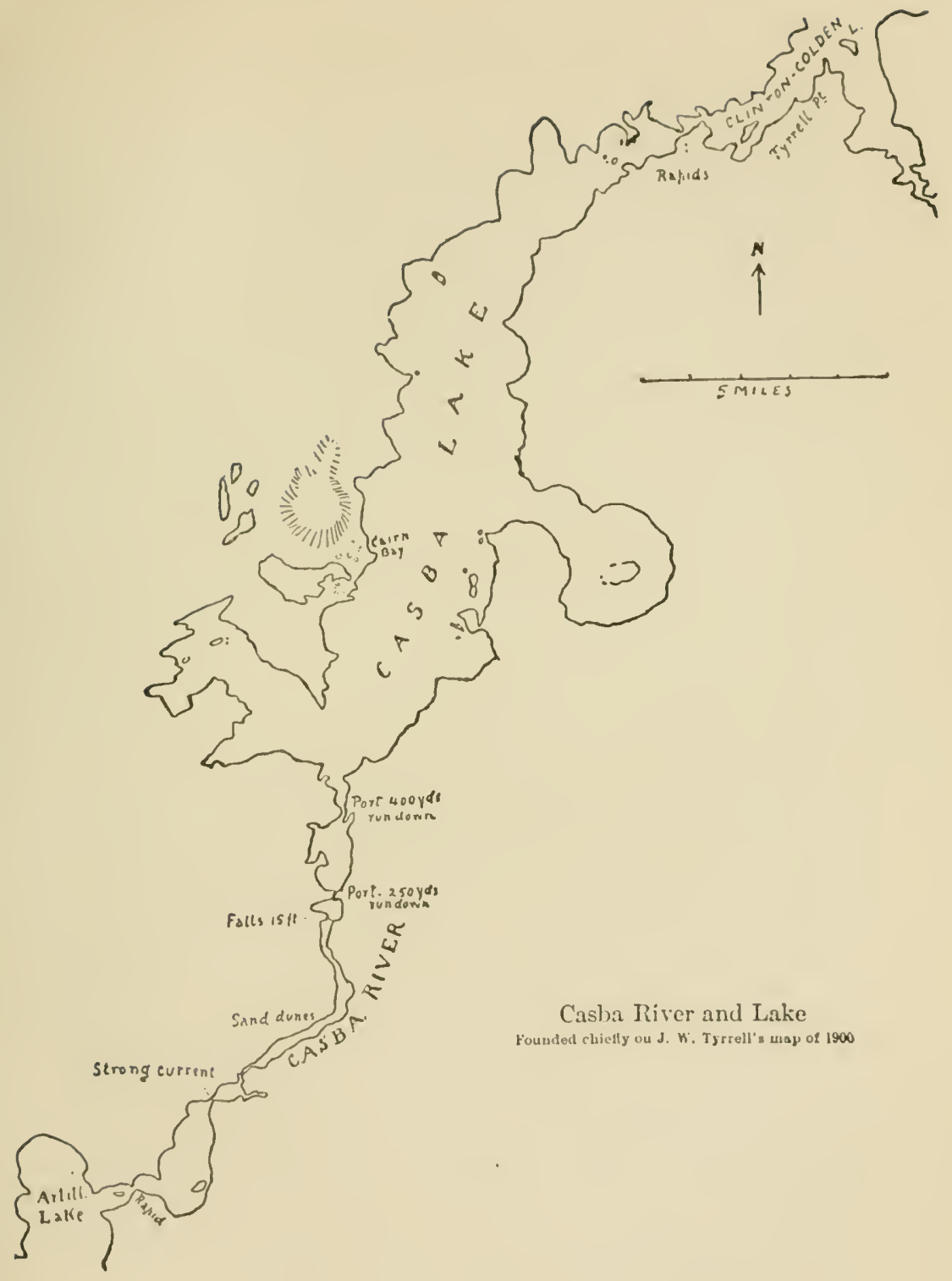


and there, with my own eyes, I saw on a ridge a mile away four great Caribou standing against the sky.

We made for a near hill and met Preble returning; he also had seen them. From a higher view-point the 4 proved part of a band of 20 .

Then other bands came in view, 16, 61, 3, 200, and so on; each valley had a scattering few, all travelling slowly southward or standing to enjoy the cool breeze that ended the torment of the flies. About 1,000 were in sight. These were my first Caribou, the first fruits of 3,000 miles of travel.

Weeso got greatly excited; these were the forerunners of the vast herd. He said, "Plenty Caribou now," and grinned like a happy child.

I went in one direction, taking only my camera. At least 20 Caribou trotted within 50 feet of me.

Billy and Weeso took their rifles intent on venison, but the Caribou avoided them, and 6 or 8 shots were heard before they got a young buck.

All that day I revelled in Caribou, no enormous herds but always a few in sight.

The next day Weeso and I went to the top ridge eastward. He with rifle, I with camera. He has a vague idea of the camera's use, but told Billy privately that "the rifle was much better for Caribou." $\mathrm{He}$ could not understand why I should restrain him from blazing away as long as the ammunition held out. "Didn't we come to shoot?" But he was amenable to discipline, and did as I wished when he understood.

Now on the top of that windy ridge I sat with this 
copper-coloured child of the spruce woods, to watch these cattle of the plains.

The Caribou is a travelsome beast, always in a hurry, going against the wind. When the wind is west, all travel west; when it veers, they veer. Now the wind was northerly, and all were going north, not walking, not galloping-the Caribou rarely gallops, and then only for a moment or two; his fast gait is a steady trot a 10-mile gait, making with stops about 6 miles an hour. But they are ever on the move; when you see a Caribou that does not move, you know at once it is not a Caribou; it's a rock.

We sat down on the hill at 3 . In a few minutes a cow Caribou eame trotting from the south, caught the wind at 50 yards, and dashed away.

In 5 minutes another, in 20 minutes a young buck, in 20 minutes more a big buck, in 10 minutes a great herd of about 500 appeared in the south. They came along at full trot, lined to pass us on the south-east. At half a mile they struck our scent and all recoiled as though we were among them. They scattered in alarm, rushed south again, then, gathered in solid body, came on as before, again to spring back and scatter as they caught the taint of man. After much and various running, seattering, and massing, they once more charged the fearsome odlour and went right through it. Now they passed at 500 yards and gave the chance for a far camera shot.

The sound of their trampling was heard a long way off-half a mile-but at 300 yards I could not distinguish the clicking of the feet, whereas this clicking 
was very plainly to be heard from the band that passed within 50 yards of me in the morning.

They snort a good deal and grunt a little, and, notwithstanding their continual haste, I noticed that from time to time one or two would lie down, but at once jump up and rush on when they found they were being left behind. Many more single deer came that day, but no more large herds.

About 4.30 a fawn of this year ( $2 \frac{1}{2}$ or 3 months) came rushing up from the north, all alone. It charged up a hill for 200 yards, then changed its mind and charged down again, then raced to a bunch of tempting herbage, cropped it hastily, dashed to a knoll, left at an angle, darted toward us till within 40 yards, then dropped into a thick bed of grass, where it lay as though it had unlimited time.

I took one photograph, and as I crawled to get one nearer, a shot passed over my head, and the merry cackle told me that Weeso had yielded to temptation and had 'collected' that fawn.

A young buck now came trotting and grunting toward us till within 16 paces, which proved too much for Weeso, who then and there, in spite of repeated recent orders, started him on the first step toward my museum collection.

I scolded him angrily, and he looked glum and unhappy, like a naughty little boy caught in some indiscretion which he cannot understand. He said nothing to me then, but later complained to Billy, asking, "What did we come for?"

Next morning at dawn I dreamed I was back in 
New York and that a couple of cats were wailing under my bedroom window. Their noise increased so that I awoke, and then I heard unaccountable caterwauls. They were very loud and near, at least one of the creatures was. At length I got up to sce. IIere on the lake a few yards from the tent was a loon swimming about, minutely inspecting the tent and uttering at intervals deep cat-like mews in expression of his curiosity.

The south wind had blown for some days before we arrived, and the result was to fill the country with Caribou coming from the north. The day after we came, the north wind set in, and continued for three days, so that soon there was not a Caribou to be found in the region.

In the afternoon I went up the hill to where Weeso left the offal of his deer. A large yellowish animal was there feeding. It disappeared over a rock and I could get no second view of it. It may have been a wolf, as I saw a fresh wolf trail near; I did not, however, see the animal's tail.

In the evening Preble and I went again, and again the creature was there, but disappeared as mysteriously as before when we were 200 yards away. Where it went we could not guess. The country was open and we scoured it with eye and glass, but saw nothing more of the prowler. It seemed to be a young Aretic wolf, ycllowish white in colour, but tailless.

Next day at noon Preble and Billy returned bearing the illusive visitor; it was a large Lynx. It was very thin and yet, after bleeding, weighed 22 pounds. But 
why was it so far from the forest, 20 miles or more, and a couple of miles from this little grove that formed the last woods?

This is another evidence of the straits the Lynxes are put to for food, in this year of famine. 


\section{CHAPTER XXXI}

\section{GOOD-BIE 'TO THE WOODS}

The last woods is a wonderfully interesting biological point or line; this ultimate arm of the forest does not die away gradually with uncertain edges and in steadily dwindling trees. The latter have sent their stoutest champions to the front, or produced, as by a final effort, some giants for the line of battle. And that line, with its sentinels, is so marked that one can stand with a foot on the territory of each combatant, or, as scientists call them, the Arctic Region and the cold Temperate.

And each of the embattled kings, Jack-frost and Sombre-pine, has his ehildren in abundanee to possess the land as he wins it. Right up to the skirmish line are they.

The low thickets of the woods are swarming with Tree-sparrows, Redpolls, Robins, Hooded Sparrows, and the bare plains, a few yards away, are peopled and vocal with birds to whom a bush is an abomination. Lap-longspur, Snowbird, Shorelarks, and Pipits are here, soaring and singing, or among the barren rocks are Ptarmigan in garments that are painted in the patterns of their rocks.

There is one sombre fowl of ampler wing that knows no line-is at home in the open or in the woods. His 
sonorous voice has a human sound that is uncanny; his form is visible afar in the desert and sinister as a gibbet; his plumage fits in with nothing but the night, which he does not love. This evil genius of the land is the Raven of the north. Its numbers increased as we

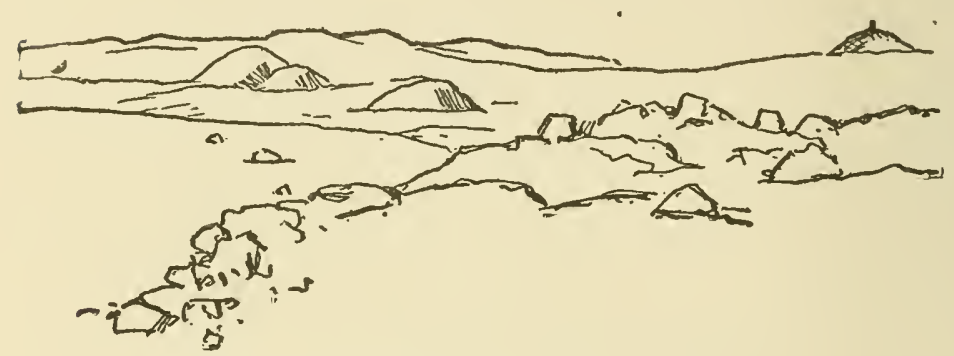

Cairn Bay, looking south. August 7, 1907

reached the Barrens, and the morning after the first Caribou was killed, no less than 28 were assembled at its offal.

An even more interesting bird of the woods is the Hooded Sparrow, interesting because so little known.

Here I found it on its breeding-grounds, a little late for its vernal song, but in September we heard its autumnal renewal like the notes of its kinsmen, Whitethroat and White-crowned Sparrows, but with less whistling, and more trilled. In all the woods of the Hudsonian Zone we found it evidently at home. But here I was privileged to find the first nest of the species known to science. The victory was robbed of its crown, through the nest having fledglings instead of eggs, but still it was the ample reward of hours of search. 
Of course it was on the ground, in the moss and ereeping plants, under some bushes of dwarf birch, screened by spruces. The structure closely resembled that of the Whitethroat, was lined with grass and fibrous roots; no down, feathers, or fur were observable. The young numbered four.

The last woods was the limit of other interesting creatures-the Ants. Wherever one looks on the ground, in a high, dry place, throughout the forest country, from Athabaska Landing northward along our route, there is to be seen at least one Ant to the square foot, usually several. Three kinds secm common-one red-bodied, another a black one with brown thorax, and a third very small and all black. They secm to live chiefly in hollow logs and stumps, but are found also on marshes, where their hills are occasionally so numerous as to form dry bridges across.

I made many notes on the growth of timber here and all along the route; and for comparison will begin at the very beginning.

In March, 1907, at my home in Connecticut, I cut down an oak tree (Q. palustris) that was 110 fect high, 32 inches in diameter, and yet had only 76 rings of annual growth.

In the Bitterroot Mountains of Idaho, where I camped in September, 1902, a yellow pine 6 feet 6 inches high was $5 \frac{1}{4}$ inches in circumference at base. It had 14 rings and 14 whorls of branches corresponding exactly with the rings.

At the same place I measured a balsam fir- 84 feet high, 15 inches in diameter at 32 inches from the 
ground. It had 52 annual rings and 50 or possibly 52 whorls of branches. The most vigorous upward growth of the trunk corresponded exactly with the largest growth of wood in the stump. Thus ring No. 33 was $\frac{3}{8}$ inch wide and whorl No. 33 had over 2 feet of growth, below it on the trunk were others which had but 6 inches.

On the stump most growth was on north-east side; there it was 9 inches, from pith to bark next on east $\delta \frac{1}{2}$ inches, on south 8 inches, north $6 \frac{1}{2}$ inches, west $6 \frac{1}{2}$ inches, least on north-west side, 6 inches. The most light in this case came from the north-east. This was in the land of mighty timber.

On Great Slave River, the higher latitude is offset by lower altitude, and on June 2, 1907, while among the tall white spruce trees I measured one of average sizc-118 feet high, 11 feet 2 inches in girth a foot from the ground ( 3 feet $6 \frac{1}{2}$ inches in diameter), and many black poplars nearly as tall were 9 feet in girth.

But the stunting effect of the short summer became marked as we went northward. At Fort Smith, June 20, I cut down a jackpine that was 12 feet high, 1 inch in diameter, with 23 annual rings at the bottom; 6 feet up it had 12 rings and 20 whorls. In all it appeared to have 43 whorls, which is puzzling. Of these 20 were in the lower part. This tree grew in dense shade.

At Fort Resolution we left the Canadian region of large timber and entered the stunted spruce, as noted, and at length on the timber line we saw the final effort of the forests to combat Jack Frost in his own king- 


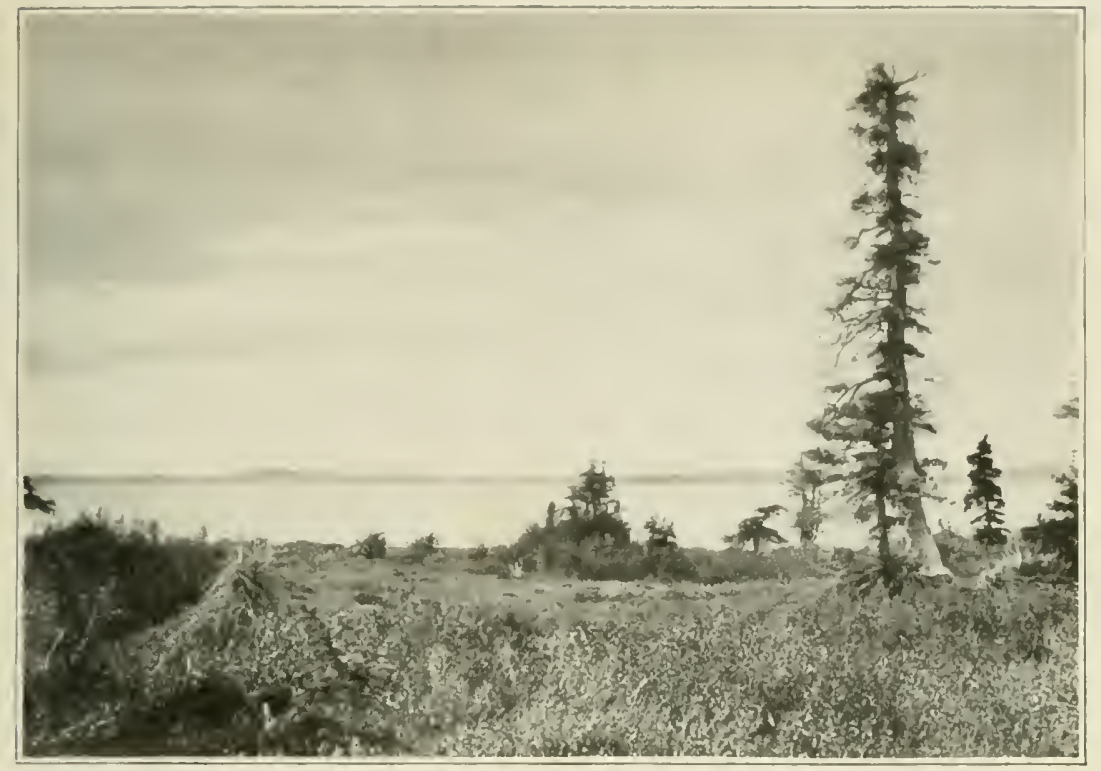

The riants on the edpe of the forest

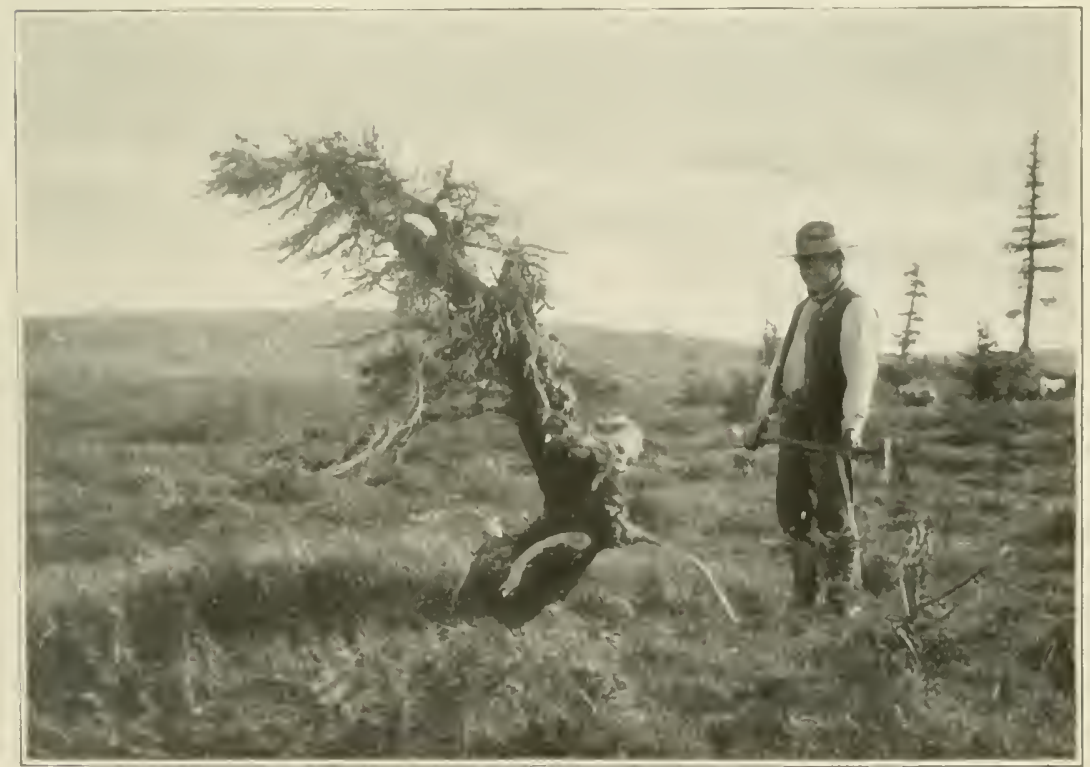

An ancient dwart about 2.50 years old. Billy ready for action. 

dom. The individual history of each tree is in three stages:

First, as a low, thick, ereeping bush sometimes ten fect across, but only a foot high. In this stage it continues until rooted enough and with capital enough to send up a long central shoot; which is stage No. 2.
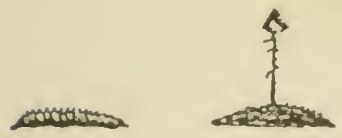

The three ages of the spruce

This central shoot is like a Noah's Ark pine; in time it becomes the tree and finally the basal thicket dies away, leaving the specimen in stage No. 3.

A stem of one of the low ereepers was cut for examination; it was $1 \frac{1}{2}$ inches through and 25 years old. Some of these low mats of spruce have stems 5 inches through. They must be fully 100 years old.

A tall, dead, white spruce at the eamp was 30 fect high and 11 inches in diameter at 4 feet from the ground. Its 190 rings were hard to count, they were so thin. The central ones were thickest, there being 16 to the inmost inch of radius; on the outside to the north 50 rings made only $\frac{1}{2}$ an inch and $\$ 6$ made one inch.

Numbers 42 and 43, counting from the outside, were two or three times as thick as those outside of them and much thicker than the next within; they must have represented years of unusual summors. No. 99 also was of great size. What years these corresponded with one could not guess, as the tree was a long time dead. 
Another, a dwarf but 8 feet high, was 12 inches through. It had 205 rings plus a 5 -inch hollow which we reckoned at about 100 rings of growth; 64 rings made only $1 \frac{3}{8}$ inches; the outmost of the 64 was 2 inches in from the outside of the wood. Those on the outer two inches were even smaller, so as to be exceedingly difficult to count. This tree was at least 300 years old; our estimates varied, according to the data, from 300 to 325 years.

These, then, are the facts for extremes. In Idaho or Connecticut it took about 10 years to produce the same amount of timber as took 300 years on the edge of the Arctic Zone.
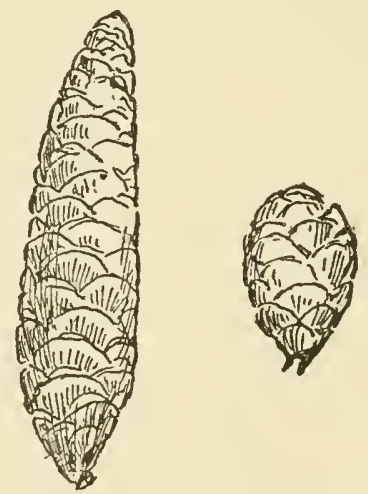

White spruce

Black spruee

(Like a red banans) (Like a purple plam) 


\section{CHAPTER XXXII}

\section{THE TREELESS PLAINS}

ON August 7 we left Camp Last Woods. Our various specimens, with a stock of food, were secured, as usual, in a cache high in two trees, in this case those already used by 'Tyrrell seven years before, and guarded by the magic necklace of cod hooks.

By noon (in 3 hours) we made fifteen miles, camping far beyond Twin Buttes. All day long the boat shot through water crowded with drowned gnats. These were about 10 to the square inch near shore and for about twenty yards out, after that 10 to the square foot for two hundred or three liundred yards still farther from shore, and for a quarter mile wide they were 10 to the square yard.

This morning the wind turned and blew from the south. At 2 r. M. we saw a band of some 60 Caribou travelling southward; these were the first seen for two or three days. After this we saw many odd ones, and about 3 o'clock a band of 400 or 500 . At night we camped on Casba River, having covered 36 miles in 7 hours and 45 minutes.

The place we had selected for camp proved to be a Caribou crossing. As we drew near a dozen of them came from the east and swam across. A second band of $S$ now appeared. We gave chase. They spurted; so did we. Our canoe was going over 6 miles an hour, 
and yet was but slowly overtaking them. They made the water foam around them. Their heads, necks, shoulders, backs, rumps, and tails were out. I never before saw land animals move so fast in the water. A fawn in danger of being left behind reared up on its mother's back and hung on with forefeet. The leader was a doe or a young buck, I could not be sure which; the last was a big buck. They soon struck bottom and bounded along on the shore. It was too dark for a picture.

As we were turning in for the night 30 Caribou came trotting and snorting through the camp. Half of them crossed the water, but the rest turned back when Billy shouted.

Later a band of two hundred passed through and around our tents. In the morning Billy complained that he could not sleep all night for Caribou travelling by his tent and stumbling over the guy ropes. From this time on we were nearly always in sight of Caribou, small bands or scattering groups; one had the feeling that the whole land was like this, on and on and on, unlimited space with unlimited wild herds.

A year afterward, as I travelled in the fair State of Illinois, famous for its cattle, I was struck by the idea that one sees far more Caribou in the north than cattle in Illinois. This State has about 56,000 square miles of land and 3,000,000 cattle; the Arctic Plains have over $1,000,000$ square miles of prairie, which, allowing for the fact that I saw the best of the range, would set the Caribou number at over $30,000,000$. There is a good deal of evidence that this is not far from the truth. 

The reader may recollect the original postulate of my plan. Other travellers have gone, relying on the abundant Caribou, yet saw none, so starved. I relied on no Caribou, I took plenty of grocerics, and because I was independent, the Caribou walked into camp nearly every day, and we lived largely on their meat, saving our groceries for an emergency, which came in an unexpected form. One morning when we were grown accustomed to this condition I said to Billy:

"How is the meat?"

"Nearly gone. We'll need another Caribou about Thursday."

"You better get one now to be ready Thursday. I do not like it so steaming fresh. See, there's a nice little buck on that hillside."

"No, not him; why he is nearly half a mile off. I'd have to pack him in. Let's wait till one comes in camp."

Which we did, and usually got our meat delivered near the door.

Caribou meat fresh, and well prepared, has no superior, and the ideal way of cooking it is of course by roasting.

Fried meat is dried meat, Boiled meat is spoiled meat,

Roast moat is best meat.

How was it to be roasted at an open fire without continued vigilance? By a very simple contrivance that I invented at the time and now offer for the use of all campers. 
A wire held the leg; on the top of the wire was a paddle or shingle of wood; above that, beyond the heat, was a cord.

The wind gives the paddle a push; it winds up the cord, which then unwinds itself. This goes on without fail and without effort, never still, and the roast is perfect.

Thus we were living on the fat of many lands and on the choicest fat of this.

And what a region it is for pasture. At this place it reminds one of Texas. Open, grassy plains, sparser reaches of sand, long slopes of mesquite, mesas dotted with cedars and stretches of chapparal and soapweed. Only, those vegetations here are willow, dwarf birch, tiny spruce, and ledum, and the country as a whole is far too green and rich. The emerald verdure of the shore, in not a few places, carried me back to the west coast of Ireland.

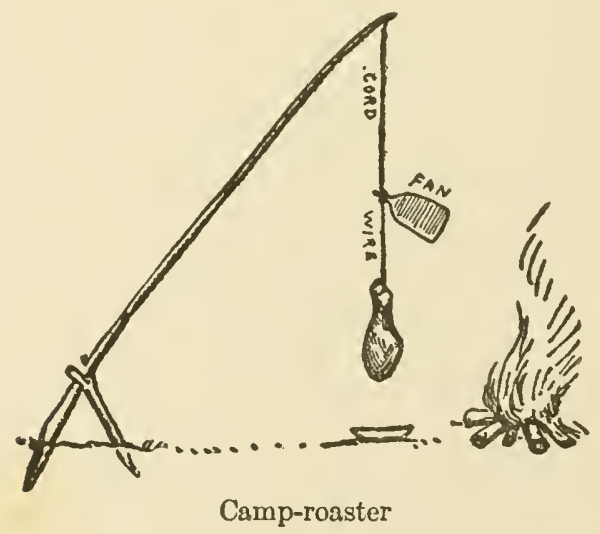




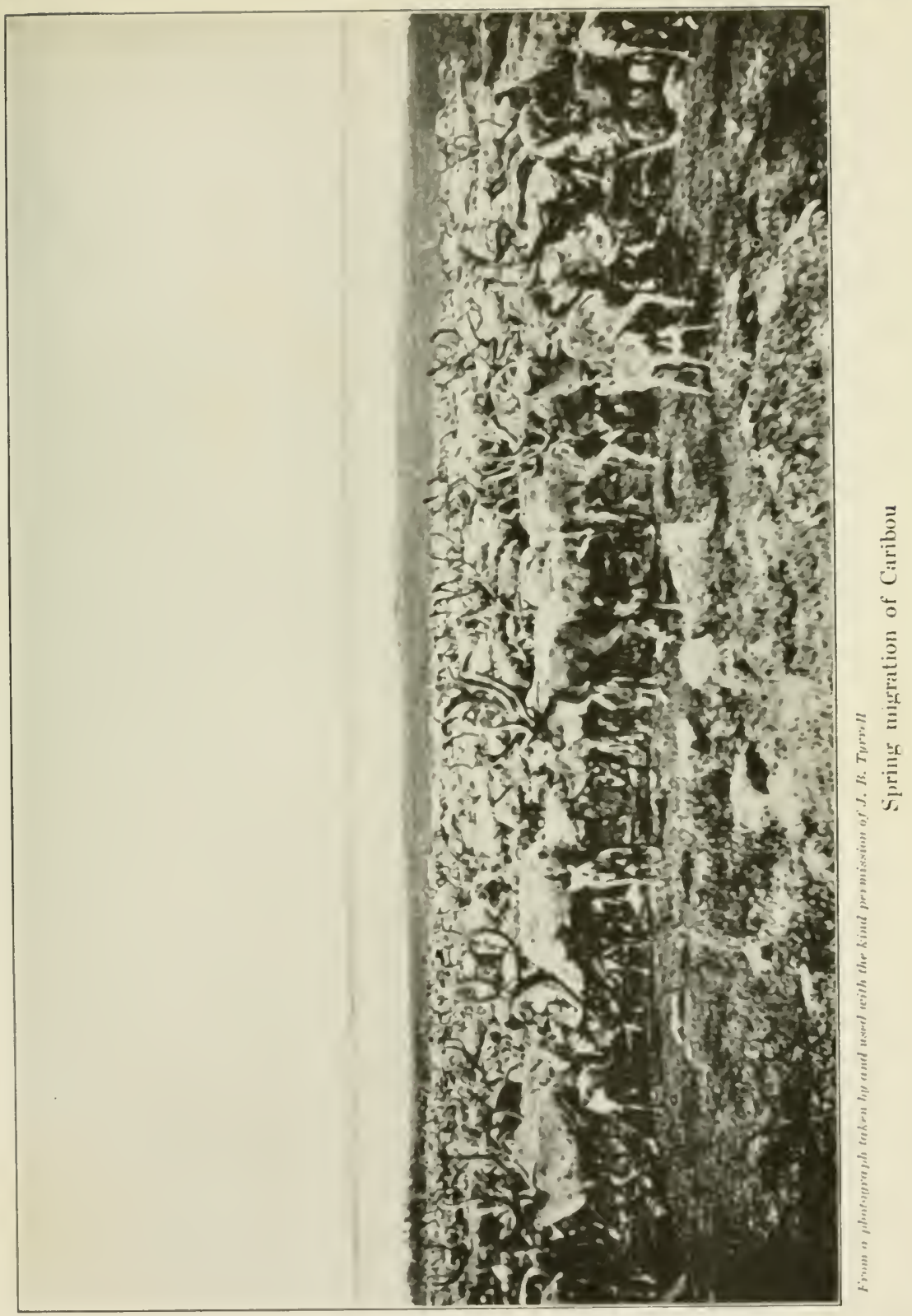





\section{CHAPTER XXXIII}

\section{TIIE UNKNOWN}

The daily observations of route and landmark I can best leave for record on my maps. I had one great complaint against previous explorers (except Tyrrell); that is, they left no monuments. Aiming to give no ground of complaint against us, we made monuments at all important points. On the night of August $S$ we camped at Cairn Bay on the west side of Casba Lake, so named because of the five remarkable glacial cairns or conical stone-piles about it. On the top of one of these I left a monument, a six-foot pillar of large stones.

On the afternoon of August 9 we passed the important headland that I have called "Tyrrell Point." Here we jumped off his map into the unknown. I had, of course, the small chart drawn by Sir George Back in 1834, but it was hastily made under great difficulties, and, with a few exceptions, it secmed impossible to recognize his landscape features. Next day I explored the east arm of Clinton-Colden and discovered the tributary that I have called "Laurier River," and near its mouth made a cairn enclosing a Caribou antler with inseription "E. T. Seton, 10 Aug." 1907."

Future travellers on this lake will find, as I did, that the Conical Butte in the eastern part is an in- 
portant landmark. It is a glacial dump about 50 feet above the general level, which again is 100 feet above the water, visible and recognizable from nearly all parts of the lake.

Thus we went on day by day, sometimes detained by head or heavy winds, but making great progress in the calm, which nearly always came in the evening; 30

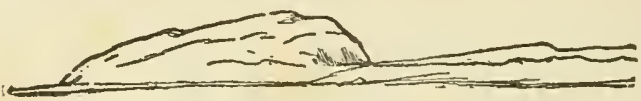

Ptarmigan Head from the east

and 35 miles a day we went, led on and stimulated by the thirst to see and know. "I must see what is over that ridge," "I must make sure that this is an island," or "Maybe from that lookout I shall see Lake Aylmer, or a band of Caribou, yes, or even a band of Musk-ox." Always there was some reward, and nearly always it was a surprise.

From time to time we came on Snowbirds with their young broods, evidently at home. Ptarmigan abounded. Parry's Groundsquirrel was found at nearly all points, including the large islands. The Laplongspur swarmed everywhere; their loud "chee chups" were the first sounds to greet us each time we neared the land. And out over all the lake were Loons, Loons, Loons. Four species abound here; they caterwaul and yodel all day and all night, each in its own particular speech. From time to time a wild hyena chorus from the tranquil water in the purple sunset haze suggested that a pack of goblin hounds were chivying a goblin buck, but it turned out always to 

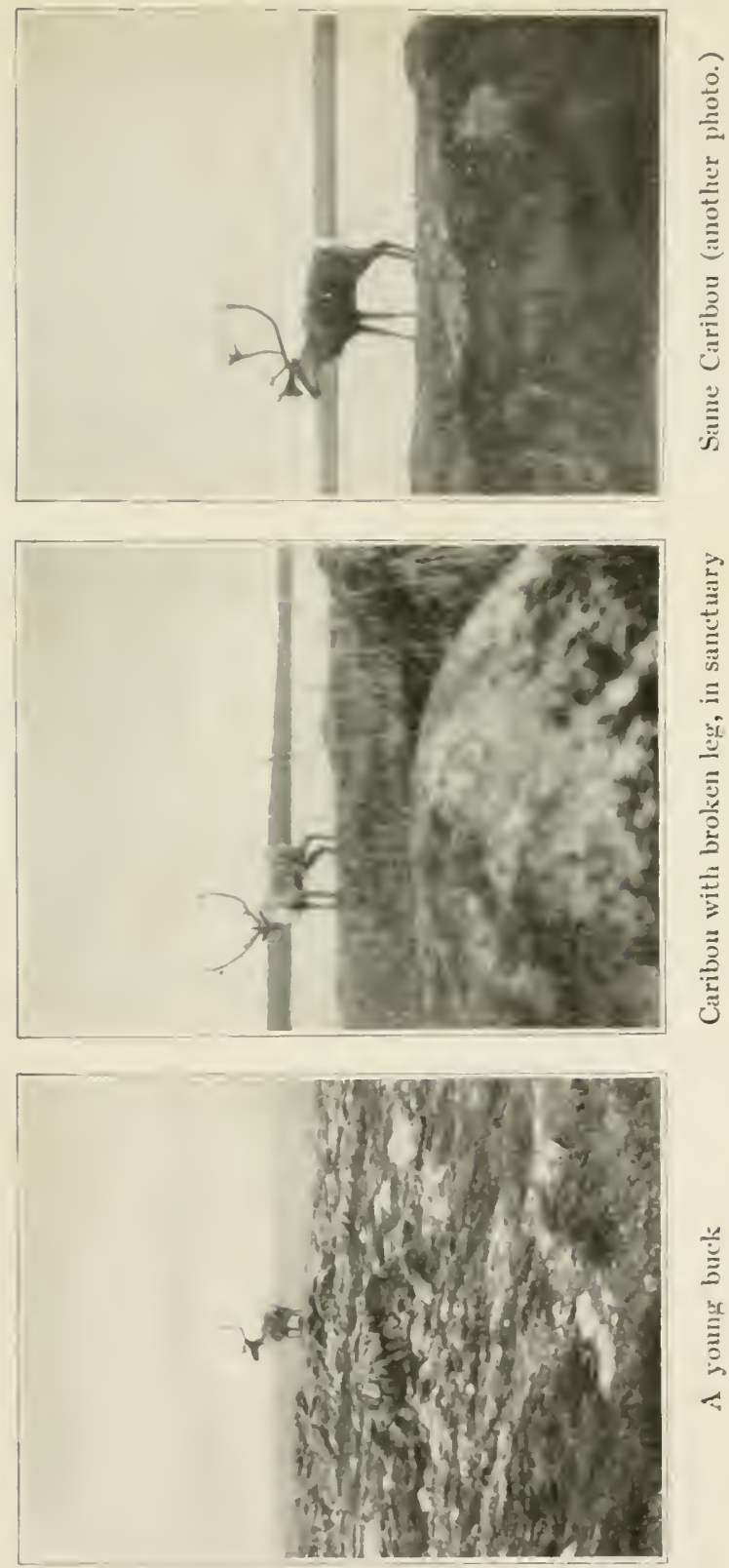

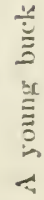



be a family of Red-throated Loons, yodelling their inspiring marching song.

One day when at Gravel Mountain, old Weeso came to camp in evident fear- "far off he had seen a man." In this country a man must mean an Eskimo; with them the Indian has a long feud; of them he is in terror. We never learned the truth; I think he was mistaken.

Once or twice the long howl of the White Wolf sounded from the shore, and every day we saw a few Caribou.

A great many of the single Caribou were on the small islands. In six cases that came under close observation the animal in question had a broken leg. A broken leg generally evidenees recent inroads by hunters, but the nearest Indians were 200 miles to the south, and the nearest Eskimo 300 miles to the north. There was every reason to believe that we were the only human beings in that vast region, and certainly we had broken no legs. Every Caribou fired at (S) had been secured and used. There is only one dangerous large enemy common in this country; that is the White Wolf. And the more I pondered it, the more it seemed sure that the Wolves had broken the Caribous' legs.

How! This is the history of each case: The Caribou is so much swifter than the Wolves that the latter have no chance in open chase; they therefore adopt the stratagem of a sneaking surround and a drive over the rocks or a precipice, where the Caribou, if not actually killed, is moro or less disabled. In some cases only a leg is broken, sand then the Caribou knows his only 
chance is to reach the water. Here his wonderful powers of swimming make him easily safe, so much so that the Wolves make no attempt to follow. The crippled deer makes for some island sanctuary, where he rests in peace till his leg is healed, or it may be, in some cases, till the freezing of the lake brings him again into the power of his foe.

These six, then, were the eripples in hospital, and I hope our respectful behaviour did not inspire them with a dangerously false notion of humanity.

On the island that I have called Owl-and-Hare, we saw the first White Owl and the first Arctic Hare.

In this country when you see a tree, you know perfectly well it is not a tree; it's the horns of a Caribou. An unusually large affair of branches appeared on an island in the channel to Aylmer. I landed, camera in hand; the Caribou was lying down in the open, but there was a tuft of herbage 30 yards from him, another at 20 yards. I crawled to the first and made a snapshot, then, flat as a rug, sneaked my way to the one estimated at 20 yards. The click of the camera, alarmed the buck; he rose, tried the wind, then lay down again, giving me another chance. Having used all the films, I now stood up. The Caribou dashed away and by a slight limp showed that he was in sanctuary. The 20 -yard estimate proved too long; it was only 16 yards, which put my picture a little out of focus.

There never was a day, and rarely an hour of each day, that we did not see several Caribou. And yet I never failed to get a thrill at each fresh one. "There's a Caribou," one says with perennial intensity that is 


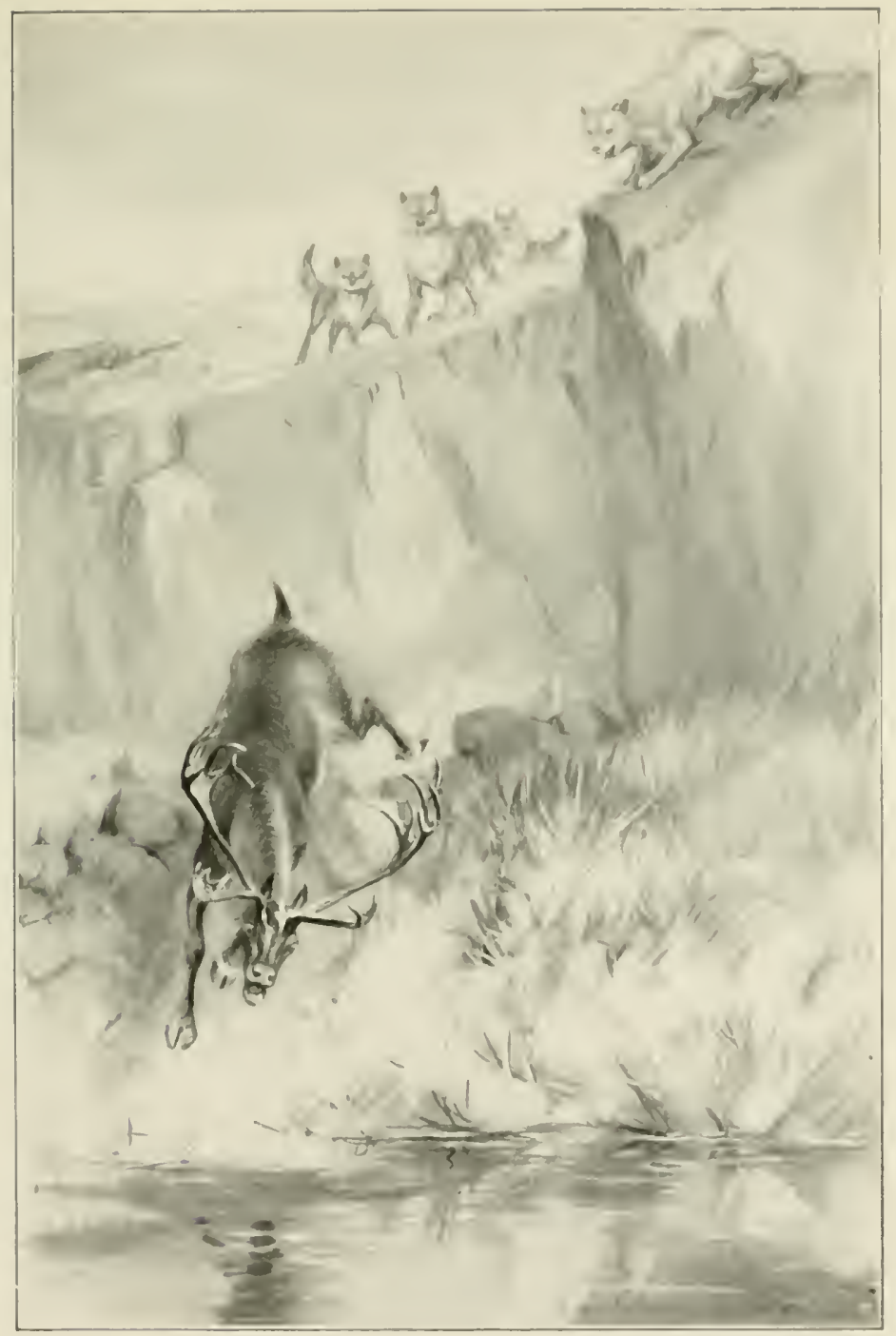

'The leap' for life 



\section{THE UNKNOWN}

evidence of perennial pleasure in the sight. There never was one sighted that did not give us a happy sense of satisfaction-the thought "This is what we came for."
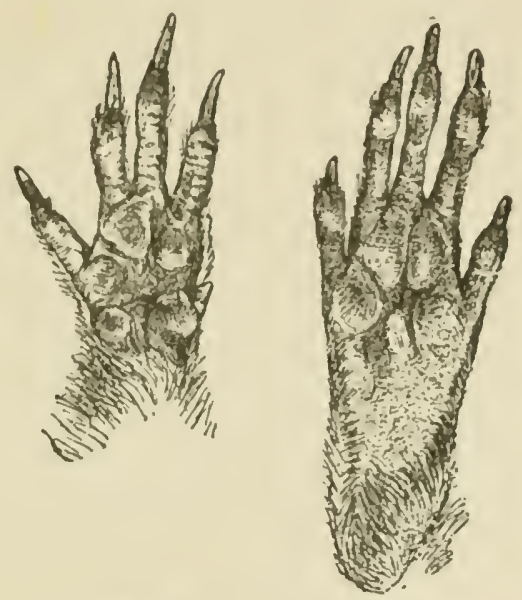

Feet of Groundsquirrel 


\section{CHAPTER XXXIV}

\section{AYLMER LAKE}

ONE of my objects was to complete the ambiguous shore line of Aylmer Lake. 'The first task was to find the lake. So we left the narrows and pushed on and on, studying the Back map, vainly trying to identify points, etc. Once or twice we saw gaps ahead that seemed to open into the great inland sea of Aylmer. But each in turn proved a mere bay. On August 12 we left the narrows; on the 13th and 14 th we journeyed westward seeking the open sea. On the morning of the 15th we ran into the final end of the farthest bay we could discover and camped at the mouth of a large river entering in.

As usual, we landed-Preble, Billy, and I-to study topography, Weeso to get firewood, and curiously enough, there was more firewood here than we had seen since leaving Artillery Lake. The reason of this appeared later.

I was utterly puzzled. We had not yet found Aylmer Lake, and had discovered an important river that did not seem to be down on any map.

We went a mile or two independently and studied the land from all the high hills; evidently we had crossed the only great sheet of water in the region. About noon, when all had assembled at camp, I said: "Preble, 


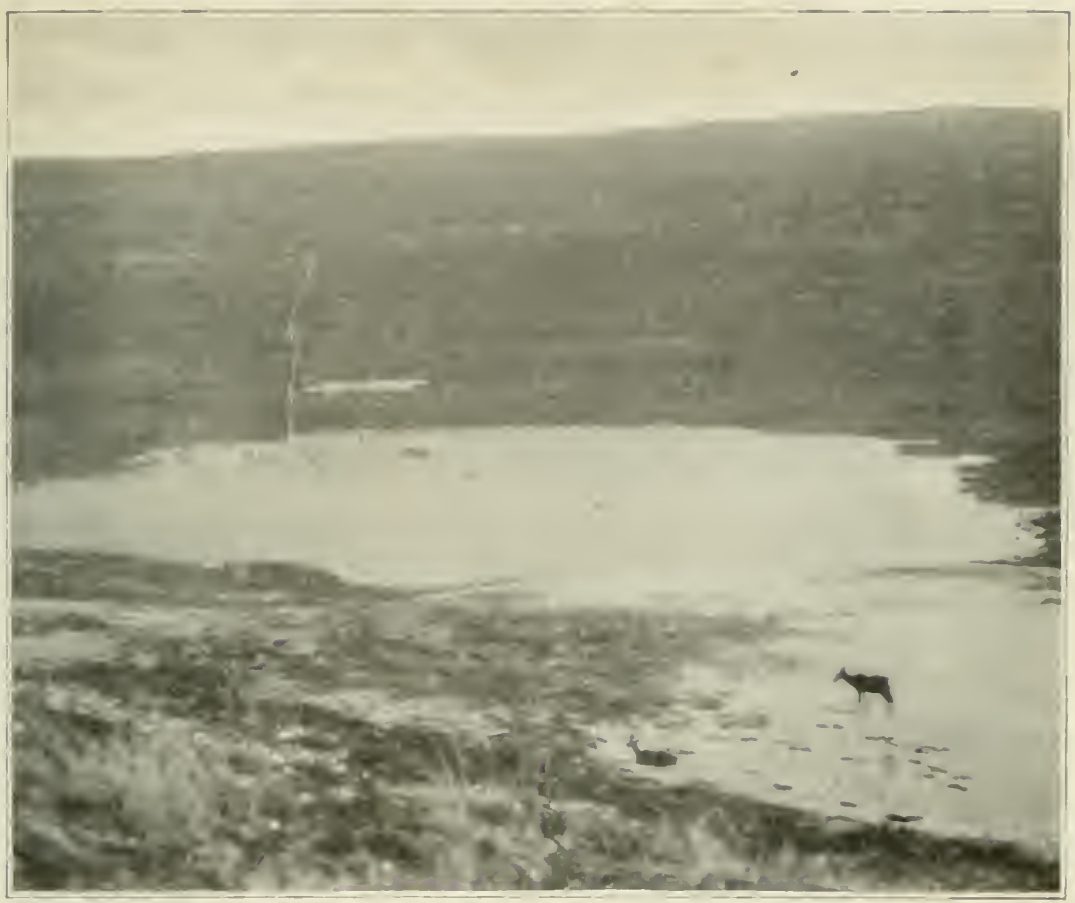

Caribou enjoyingr a brecze

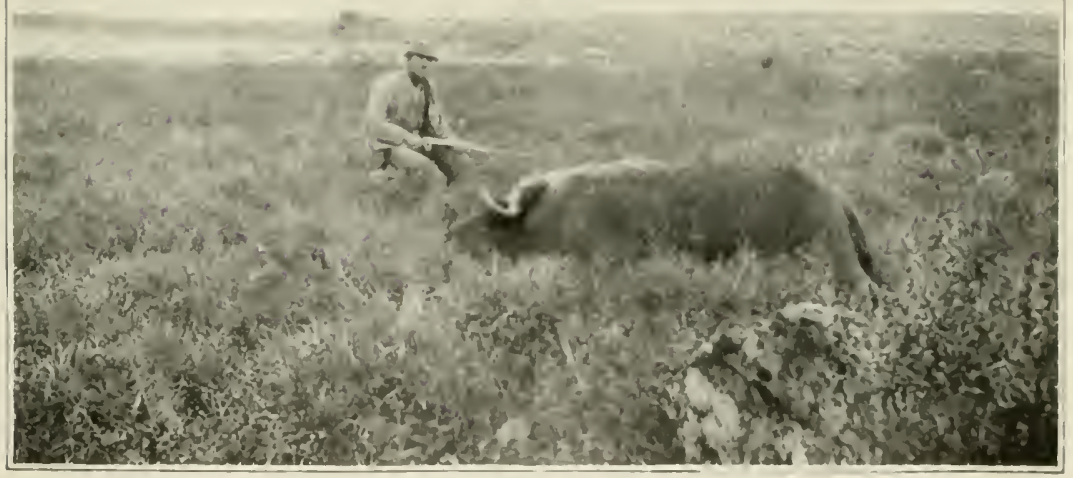

The trophy that weighed nine hundred pounds 



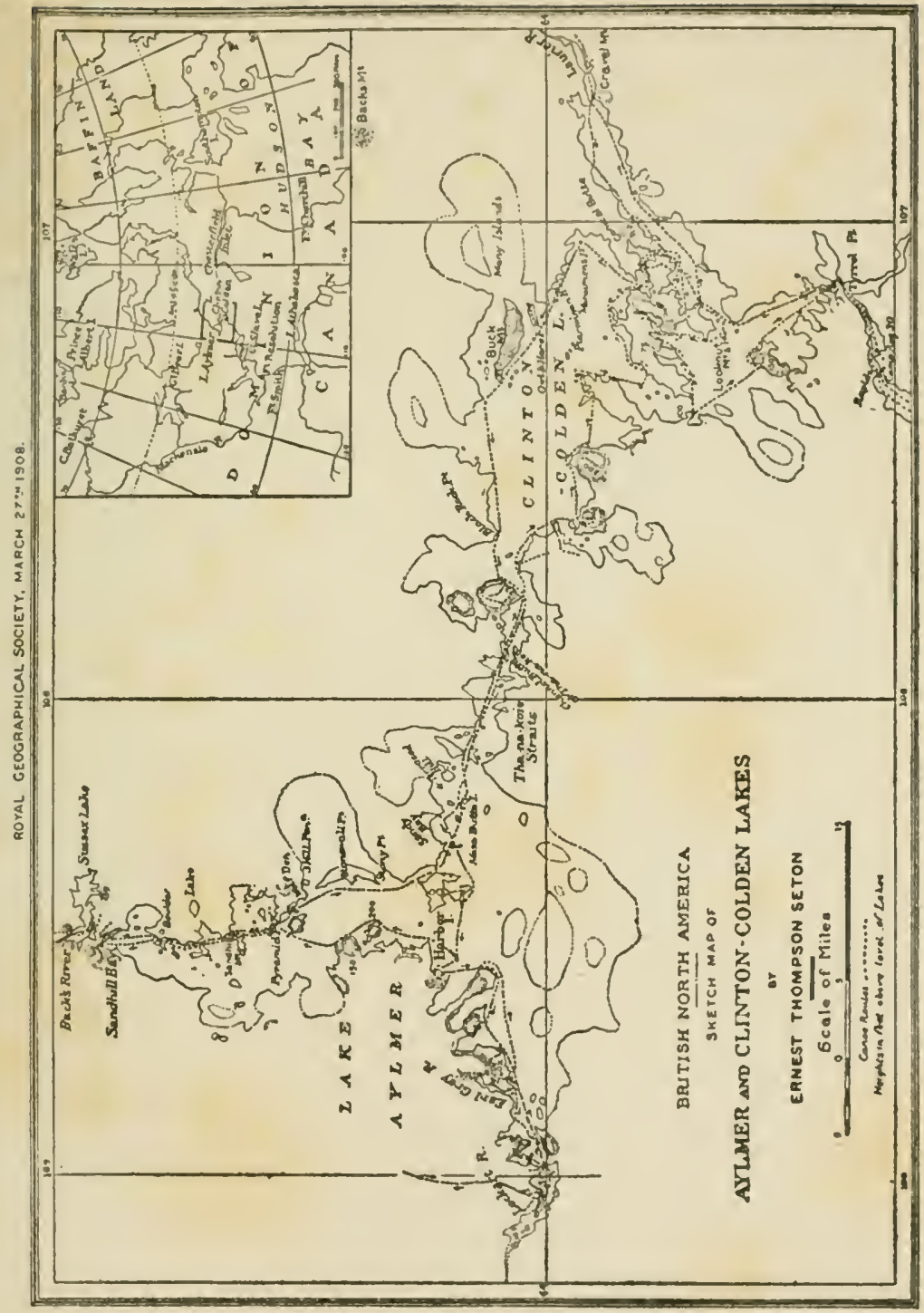


why, isn't this Lockhart's River, at the western extremity of Aylmer Lake?" The truth was dawning on me.

He also had been getting light and slowly replied: "I have forty-nine reasons why it is, and none at all why it isn't."

There could be no doubt of it now. The great open sea of Aylmer was a myth. Back never saw it; he passed in a fog, and put down with a query the vague information given him by the Indians. This little irregular lake, much like Clinton-Colden, was Aylmer. We had covered its length and were now at its farthest western end, at the mouth of Lockhart's River.

How I did wish that explorers would post up the names of the streets; it is almost as bad as in New York City. What a lot of time we might have saved had we known that Sandy Bay was in Back's three-fingered peninsula! Resolving to set a good example I left a monument at the mouth of the river. The kind of stone made it easy to form a cross on top. This will protect it from wandering Indians; I do not know of anything that will protect it from wandering white men.

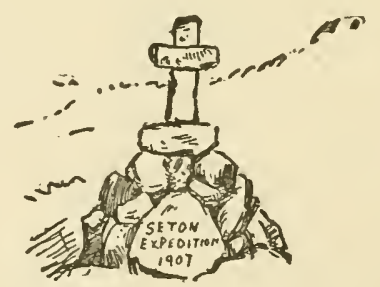

Near mouth of Lockhart River 


\section{CHAPTER XXXV}

\section{THE MIUSK-OX}

In the afternoon, Preble, Billy, and I went northward on foot to look for Musk-ox. A couple of miles from camp I left the others and went more westerly.

After wandering on for an hour, disturbing Longspurs, Snowbirds, Pipits, Groundsquirrel, and Caribou, I came on a creature that gave me new thrills of pleasure. It was only a Polar Hare, the second we had seen; but its very scarceness here, at least this year, gave it unusual interest, and the Hare itself helped the feeling by letting me get near it to study, sketch, and photograph.

It was exactly like a Prairie Hare in all its manners, even to the method of holding its tail in running, and this is one of the most marked and distinetive peculiarities of the different linds.

On the 16th of August we left Lockhart's River, knowing now that the north arm of the lake was our way. We passed a narrow bay out of which there seemed to be a current, then, on the next high land, noted a large brown spot that moved rather quickly along. It was undoubtedly some animal with short legs, whether a Wolverine a mile away, or a Musk-ox two miles away, was doubtful. Now did that canoe put on its six-mile gait, and we soon knew for certain 
that the brown thing was a Musk-ox. We were not yet in their country, but here was one of them to meet us. Quickly we landed. Guns and cameras were loaded.

"Don't fire till I get some pictures-unless he charges," were the orders. "And then we raced after

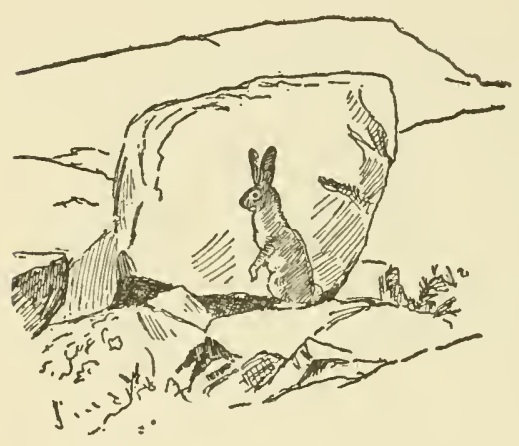

Arctic Hare. August 15, 1907 the great creature grazing from us.

We had no idea whether he would run away or charge, but knew that our plan was to remain unseen as long as possible. So, hiding behind rocks when he looked around, and dashing forward when he grazed, we came unseen within two hundred yards, and had a good look at the huge woolly ox. He looked very much like an ordinary Buffalo, the same in colour, size, and action. I never was more astray in my preconcept of any animal, for I had expected to see something like a large brown sheep.

My first film was fired. Then, for some unknown reason, that Musk-ox took it into his head to travel fast away from us, not even stopping to graze; he would soon have been over a rocky ridge. I nodded to Preble. His rifle rang; the bull wheeled sharp about with an angry snort and came toward us. His head was up, his eye blazing, and he looked like a South African Buffalo and a Prairie Bison combined, and 


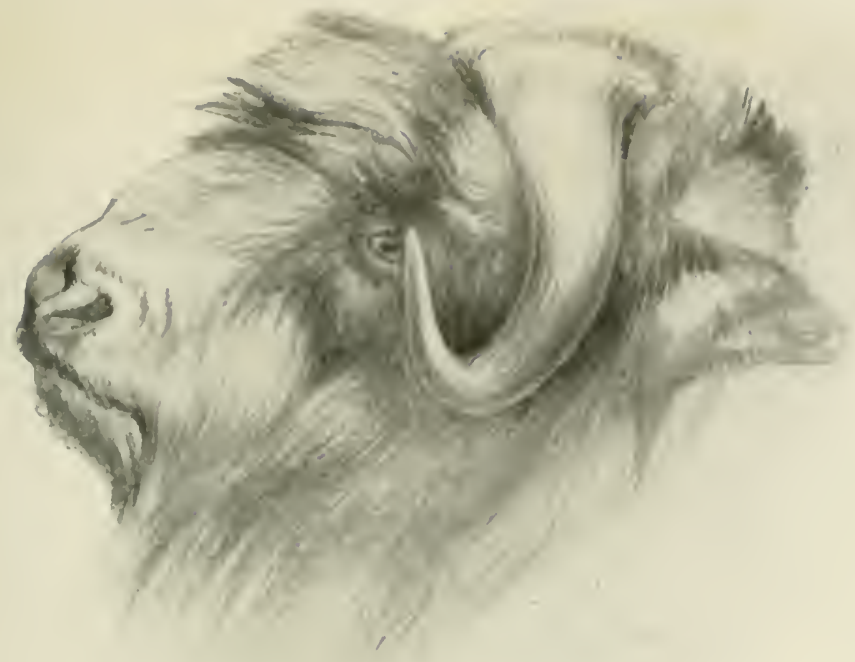

'The head of the Musk-ox

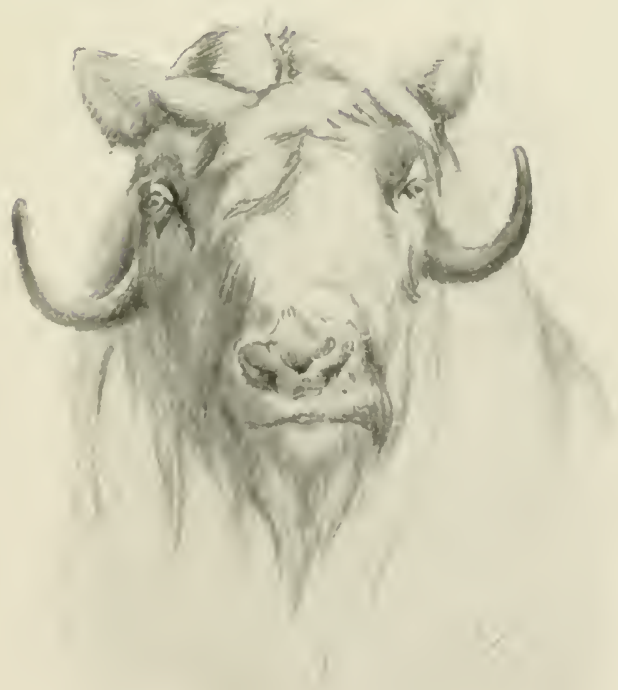

Head of bull Musk-ox-a jencil study 

seemed to get bigger at every moment. We were safely hidden behind rocks, some fifty yards from him now, when I got my second snap.

Realising the occasion, and knowing my men, I said: "Now, Preble, I am going to walk up to that bull and get a close picture. He will certainly charge me,
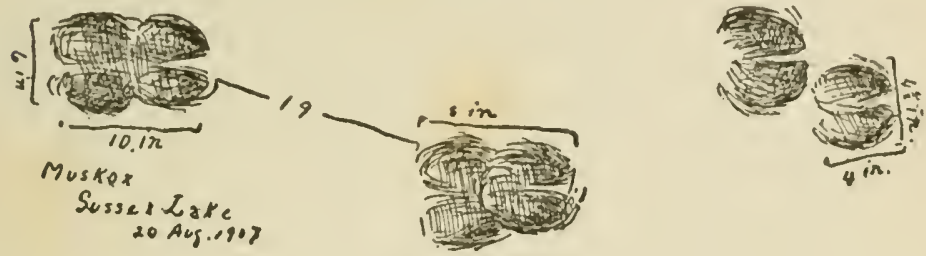

Tracks of Musk-ox

as I shall be nearest and in full view. There is only one combination that can save my life: that is you and that rifle."

Then with characteristic loquacity did Preble reply: "Go ahead."

I fixed my camera for twenty yards and quit the sheltering rock. The bull snorted, shook his head, took aim, and just before the precious moment was to arrive a heavy shot behind me rang out, the bull staggered and fell, shot through the heart, and Weeso cackled aloud in triumph.

How I cursed the meddling old fool. He had not understood. He saw, as he supposed, "the Okimow in peril of his life,"and acted according to the dictates of his accursedly poor discretion. Never again shall he carry a rifle with me.

So the last scene came not, but we had the trophy 
of a Musk-ox that weighed nine hundred pounds in life and stood five feet high at the shoulders-a world's record in point of size.

Now we must camp perforce to save the specimen. Measurements, photos, sketches, and weights were needed, then the skinning and preparing would be a

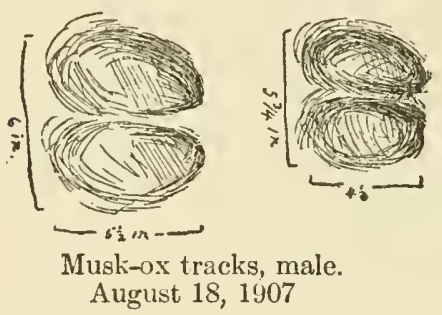
heavy task for all. In the many portages afterwarcls the skull was part of my burden; its weight was actually forty pounds, its heaviness was far over a hundred.

What extraordinary luck we were having. It was impossible in our time limit to reach the summer haunt of the Caribou on the Aretic Coast, therefore the Caribou came to us in their winter haunt on the Artillery Lake. We did not expect to reach the real Musk-ox country on the Lower Back River, so the Musk-ox sought us out on Aylmer Lake. And yet one more piece of luck is to be recorded. That night something came in our tent and stole meat. The next night Billy set a trap and secured the thief-an Arctic Fox in summer coat. We could not expect to go to him in his summer home, so he came to us.

While the boys were finishing the dressing of the bull's hide, I, remembering the current from the last bay, set out on foot over the land to learn the reason. A couple of miles brought me to a ridge from which I made the most important geographical discovery of the journey. Stretching away before me to the far 


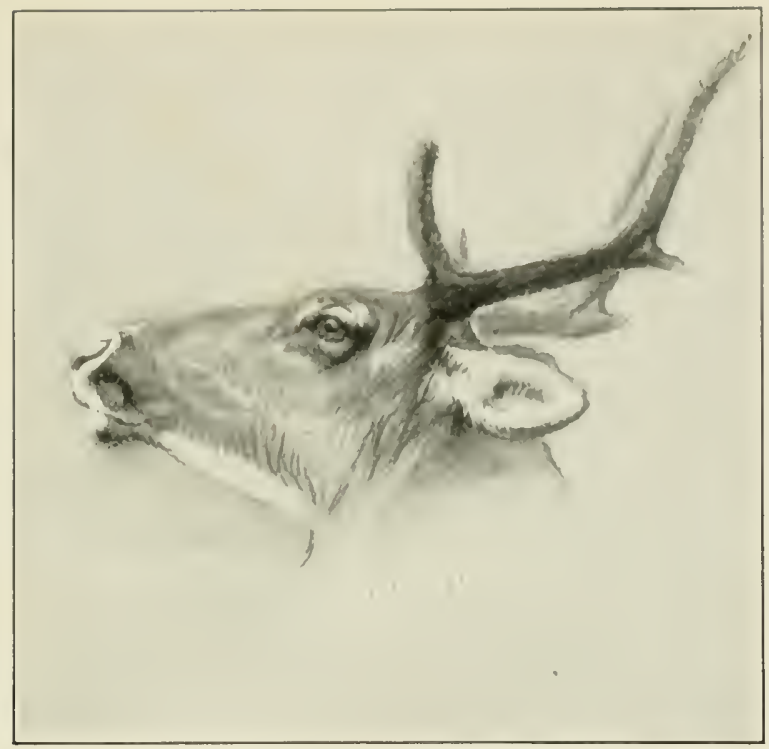

Head of a young buck

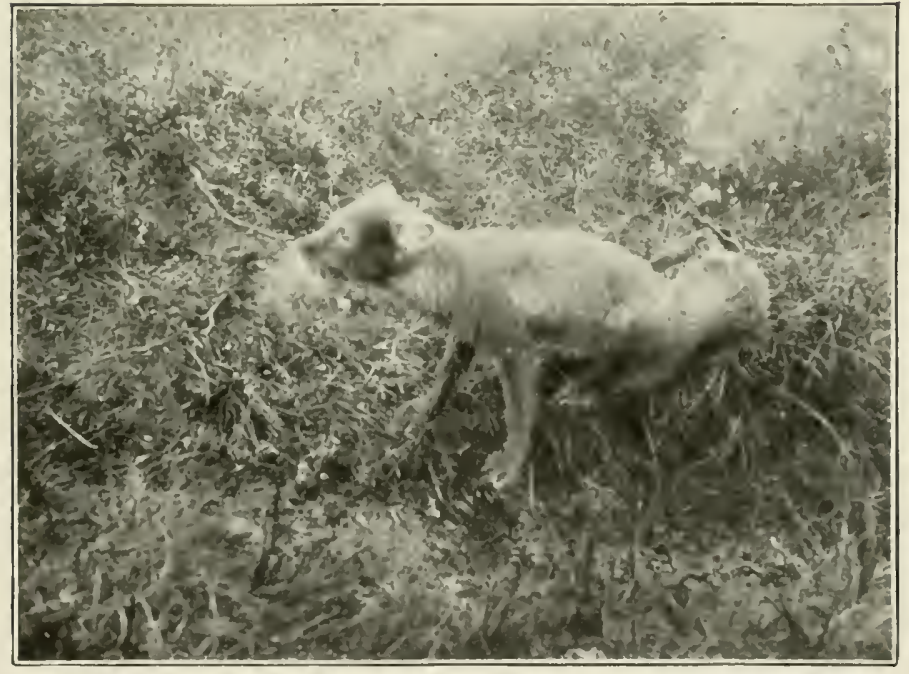

An Arctic fox in his summer coat 

dim north-west was a great, splendid river-broad, two hundred yards wide in places, but averaging serenty or eighty yards across-broken by white rapicls and waterfalls, but blue deep in the smoother stretches and emptying into the bay we had noticed. So far as the record showed, I surely was the first

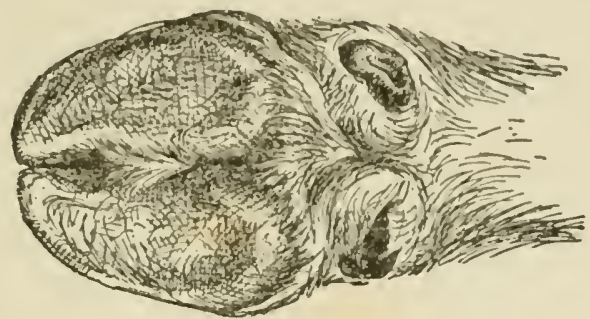

Left front foot of male Musk-ox

white man to behold it. I went to the margin; it was stocked with large trout. I followed it up a couple of miles and was filled with the delight of discovery. "Earl Grey River" I have been privileged to name it, after the distinguished statesman, now Governorgeneral of Canada.

Then and there I built a cairn, with a record of my visit, and sitting on a hill with the new river below me, I felt that there was no longer any question of the expedition's success. The entire programme was carried out. I had proved the existence of abundance of Caribou, had explored Aylmer Lake, had discovered two great rivers, and, finally, had reached the land of the Musk-ox and secured a record-breaker to bring away. This I felt was the supreme moment of the journey. 
Realizing the farness of my camp from human abode-it could scarcely have been farther on the continent-my thoughts flew back to the dear ones at home, and my comrades, the men of the Camp-fire Club. I wondered if their thoughts were with me at the time. How they must envy me the chance of launching into the truly unknown wilderness, a land still marked on the maps as "unexplored!" How I enjoyed the thoughts of their sympathy over our probable perils and hardships, and imagined them crowding around me with hearty greetings on my safe return! Alas! for the rush of a great city's life and crowds, I found out later that these, my companions, did not even know that I had been away from New York.
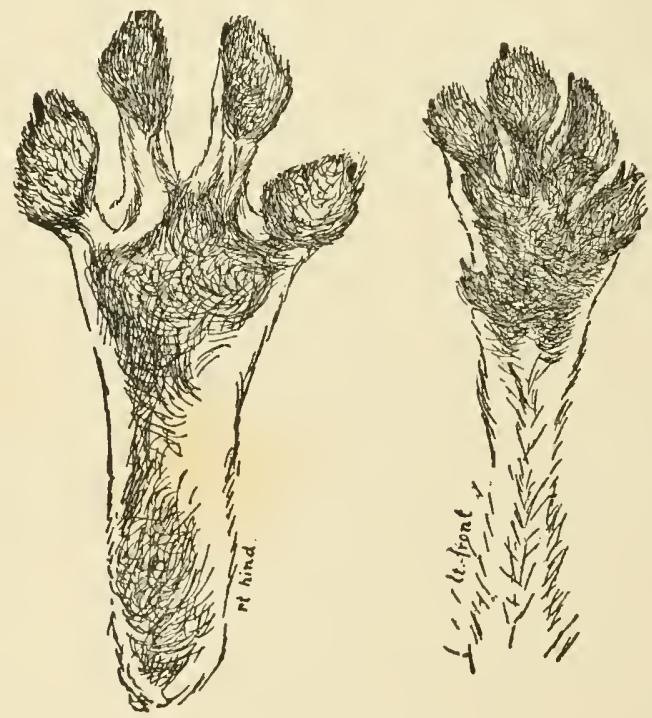

Feet of Polar Hare 


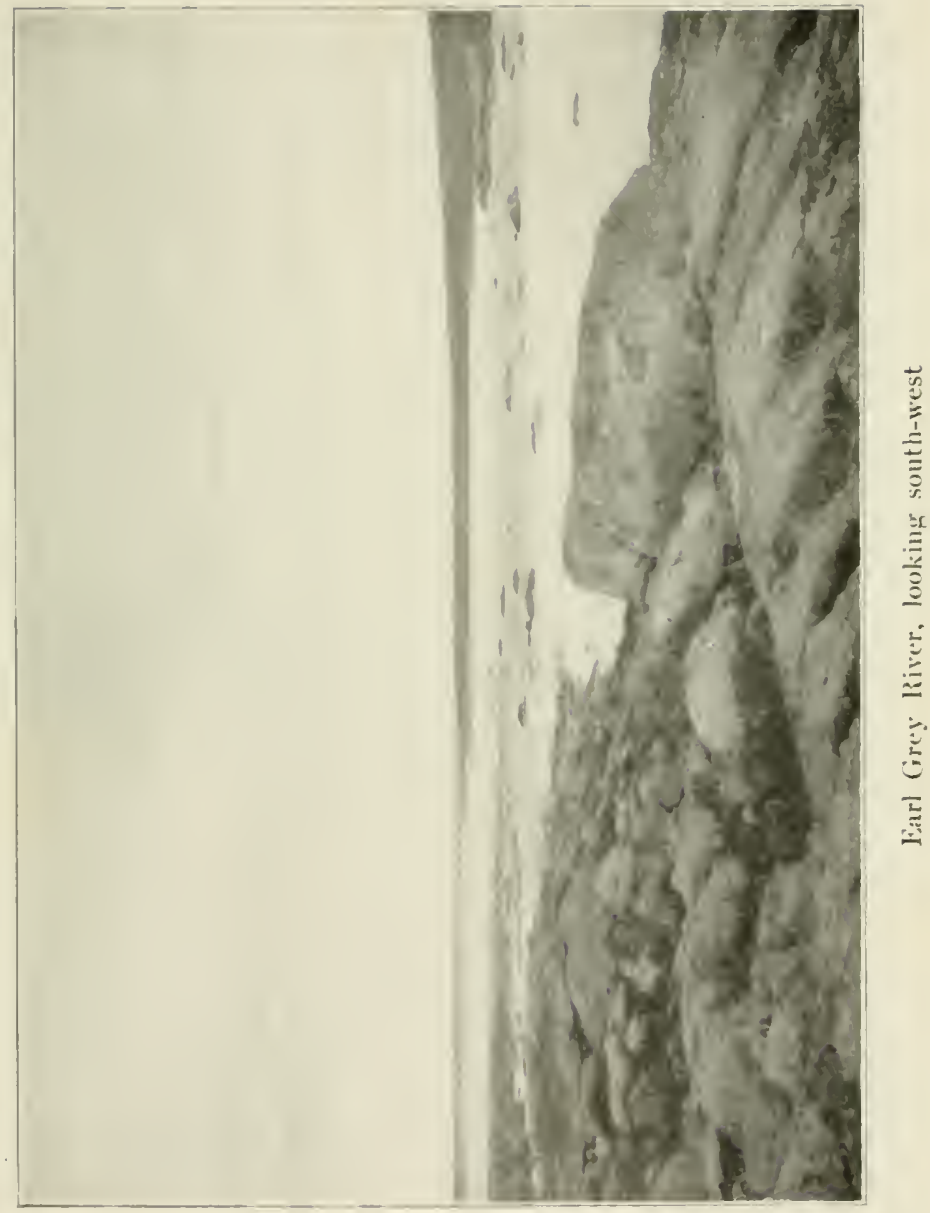





\section{CHAPTER XXXVI}

\section{THE ARC'TIC PRAIRIES AND MY FARTHEST NOR'TH}

Camp Musk-ox provided many other items of interest besides the Great River, the big Musk-ox, and the Aretic Fox. Here Preble secured a Groundsquirrel with its check-pouches full of mushrooms and shot a cock Ptarmigan whose crop was crammed with leaves of willow and birch, though the ground was bright with berries of many kincts. The last evening we were there a White Wolf followed Billy into camp, kecping just beyond reach of his shotgun; and, of course, we saw Caribou every hour or two.

"All aboard," was the cry on the morning of August 19 , and once more we set out. We reached the north arm of the lake, then turned north-eastward. In the evening I got photos of a Polar Hare, the third we had seen. The following day (August 20), at noon, we camped in Sandhill Bay, the north point of Aylmer Lake and the northernmost point of our travels by canoe. It seems that we were the fourth party of white men to camp on this spot.

Captain George Back, 1833-34.

Stewart and Anderson, 1855.

Warburton Pike, 1890.

E. T. Seton, 1907. 
All day long we had seen small bands of Caribou. A score now appeared on a sandhill half a mile away; another and another lone specimen trotted past our camp. One of these stopped and gave us an extraordinary exhibition of agility in a sort of St. Vitus's jig, jumping, kicking, and shaking its head; I suspect the nose-worms were annoying it. While we lunched, a fawn came Our Cairn at Sand Hill Bay and gazed curiously from a distance of 100 yards. In the afternoon Preble returned from a walk to say that the Caribou were visible in all directions, but not in great bands.

Next morning I was awakened by a Caribou clattering through camp within 30 feet of my tent.

After breakfast we set off on foot northward to seek for Musk-ox, keeping to the eastward of the Great Fish River. The country is rolling, with occasional rocky ridges and long, level moadows in the lowlands, practically all of it would be considered horse country; and nearly every meadow had two or three grazing Caribou.

About noon, when six or seven miles north of Aylmer, we halted for rest and lunch on the top of the long ridge of glacial dump that lies to the east of Great Fish River. And now we had a most complete and spectacular view of the immense open country that we had come so far to see. It was spread before us like a huge, minute, and wonderful chart, and plainly marked with the processes of its shaping-time. 

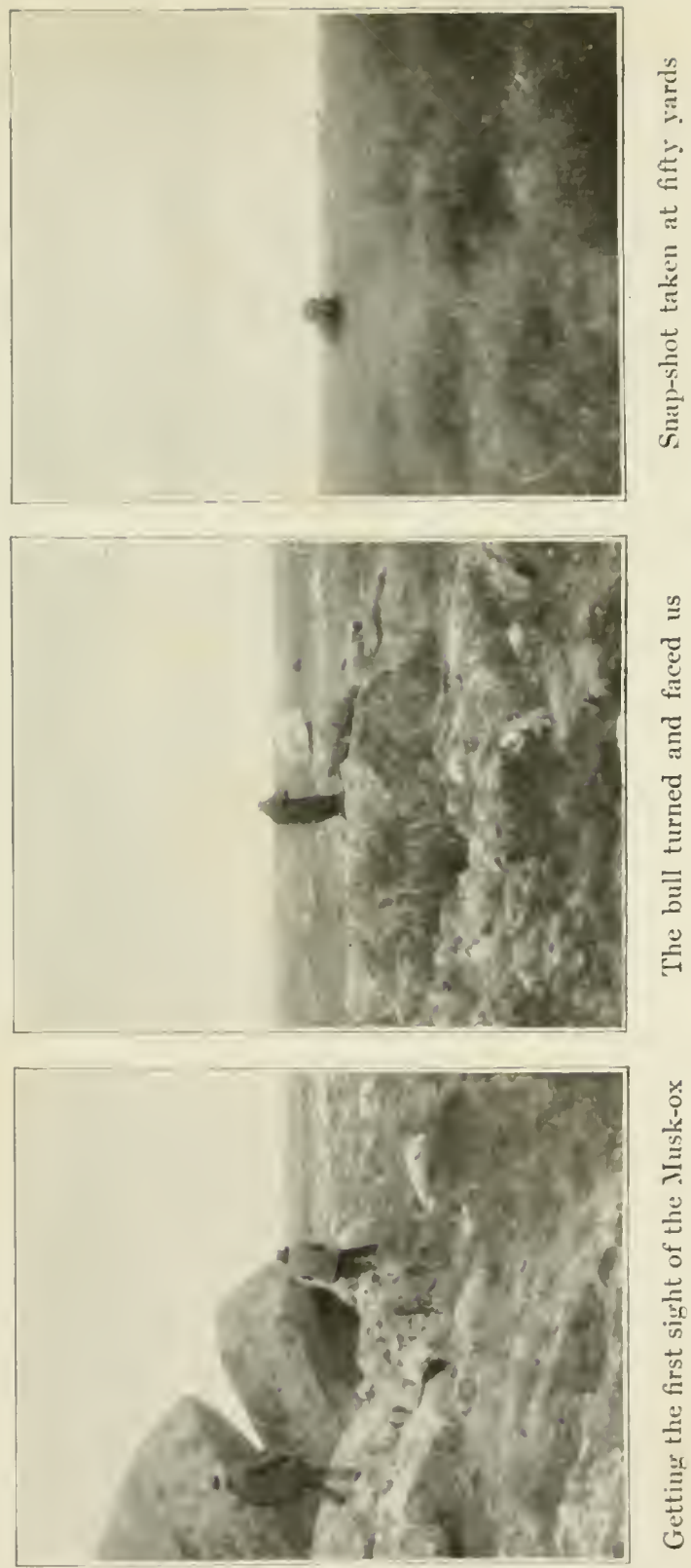

Imagine a region of low archacan hills, extending one thousand miles cach way, subjected for thousands of ycars to a contimual succession of glaciers, crushing, grinding, planing, smoothing, ripping up and smoothing again, carrying off whole ranges of broken hills, in fragments, to dump them at some other point, grind them again while there, and then push and hustle them out of that region into some other a few hundred miles farther; there again to tumble and grind them together, pack them into the hollows, and dump them in pyramidal piles on plains and uplands. Imagine this going on for thousands of years, and we shall have the hills lowered and polished, the valleys more or less filled with broken rocks.

Now the glacial action is succeeded by a time of flood. For another age all is below water, dammed by the northern ice, and icebergs breaking from the parent sheet carry bedded in them countless boulders, with which they go travelling south on the open waters. As they melt the boulders are dropped; hill and hollow share equally in this age-long shower of erratics. Nor does it cease till the progress of the warmer day removes the northern ice-clam, sets free the flood, and the region of archacan rocks stands bare and dry.

It must have been a dreary spectacle at that time, low, bare hills of gneiss, granite, etc.; low valleys halffilled with broken rock and over everything a sprinkling of erratic boulders; no living thing in sight, nothing green, nothing growing, nothing but evidence of mighty power used only to destroy. A waste of shattered granite spotted with hundreds of lakes, thou- 
sands of lakelets, millions of ponds that are marvellously blue, clear, and lifeless.

But a new force is born on the scene; it attacks not this hill or rock, or that loose stone, but on every point of every stone and rock in the vast domain, it appears - the lowest form of lichen, a mere stain of gray. This spreads and by its own corrosive power eats foothold on the granite; it fructifies in little black velvet

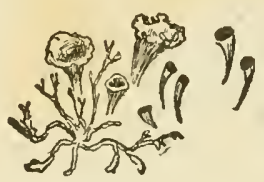

Bugle moss

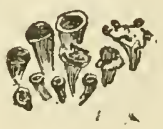

Lichens

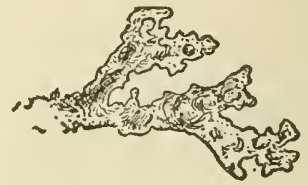

Cetraria

spots. Then one of lilac flecks the pink tones of the granite, to help the effect. Soon another kind follows - a pale olive-green lichen that fruits in bumps of rich brown velvet; then another branching like a tiny tree - there is a ghostly kind like white chalk rubbed lightly on, and yet another of small green blots, and one like a sprinkling of scarlet snow; each, in turn, of a higher and larger type, which in due time prepares the way for mosses higher still.

In the less exposed places these come forth, seeking the shade, searching for moisture, they form like small sponges on a coral reef; but growing, spread and change to meet the changing contours of the land they win, and with every victory or upward move, adopt some new refined intensive tint that is the outward and visible sign of their diverse inner excellences and their triumph. Ever evolving they spread, until there are 


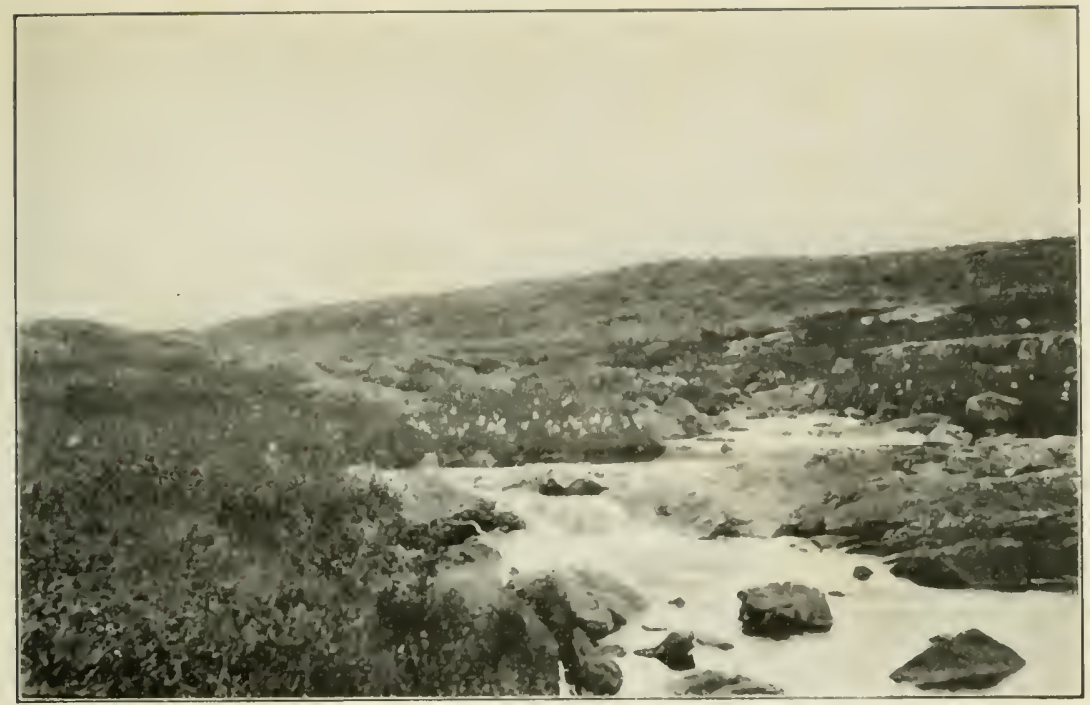

The trout brook back of 'lyrrell's Nionmment, I anst Woods

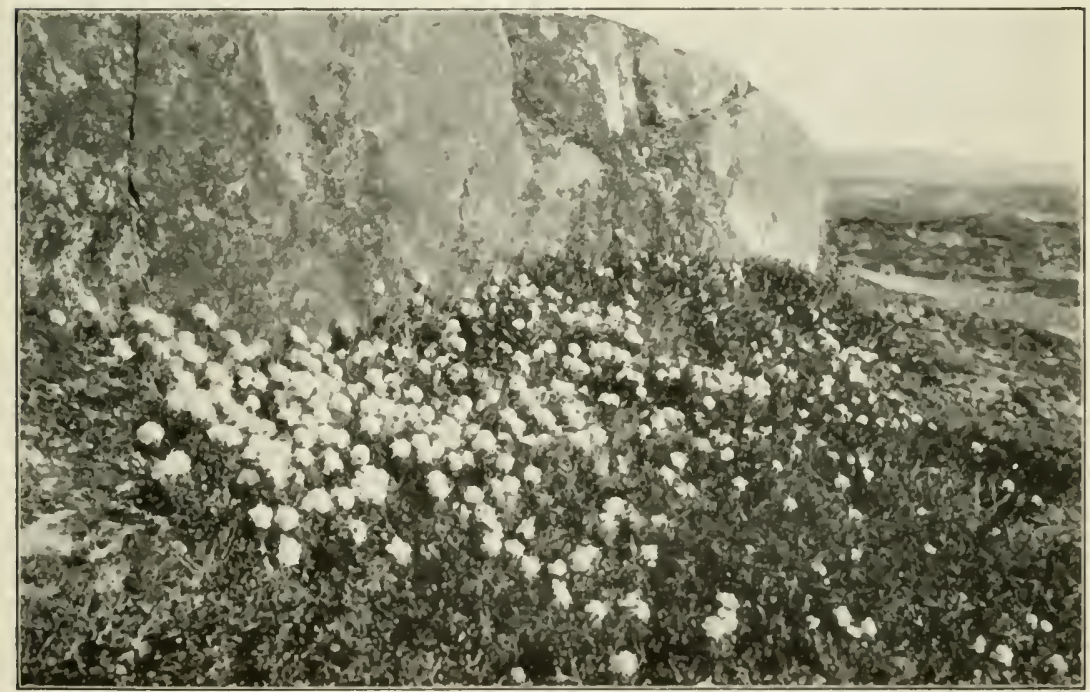

Typical lindscaue, Aretic l'rairies 

great living rugs of strange textures and oriental tones; broad carpets there are of gray and green; long luxurious lanes, with lilac mufflers under foot, great beds of a moss so yellow chrome, so spangled with intense red sprigs, that they might, in clumsy hands, look raw. There are knee-deep breadths of polytrichum, which blends in the denser shade into a moss of delicate crinson plush that baffles description.

Down between the broader masses are bronze-green growths that run over cach slight dip and follow down

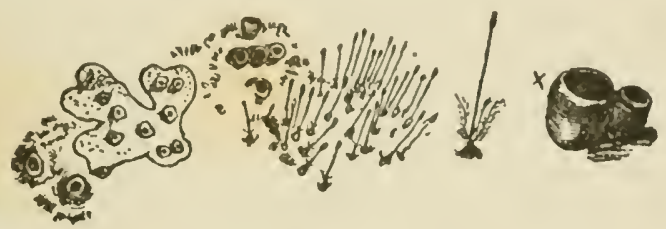

Lichens and moss forms

the rock crannies like streams of molten brass. Thus the whole land is overlaid with a living, corrosive mantle of activities as varied as its hues.

For ages these toil on, improving themselves, and improving the country by filing down the granite and strewing the dust around each rock.

The frost, too, is at work, breaking up the granite lumps; on every ridge there is evidence of that-low, rounded piles of stone which plainly are the remnants of a boulder, shattered by the cold. Thus, lichen, moss, and frost are toiling to grind the granite surfaces to dust.

Much of this porwdered rock is washed by rain into the lakes and ponds; in time these cut their exits 
down, and drain, leaving each a broad mud-flat. The climate mildens and the south winds cease not, so that wind-borne grasses soon make green meadows of the broad lake-bottom flats.

The process climbs the hill-slopes; every little earthy foothold for a plant is claimed by some new settler, until each low hill is covered to the top with vegetation graded to its soil, and where the flowering kinds cannot establish themselves, the lichen pioneers still maintain their hold. Rarely, in the landscape, now, is any of the primitive colour of the rocks; even the tall, straight Saxifrage cliffs of Aylmer are painted and frescoed with lichens that flame and glitter with purple and orange, silver and gold. How precious and fertile the ground is made to seem, when every square foot of it is an exquisite elfin garden made by the little people, at infinite cost, filled with dainty flowers and still later embellished with delicate fruit.

One of the wonderful things about these
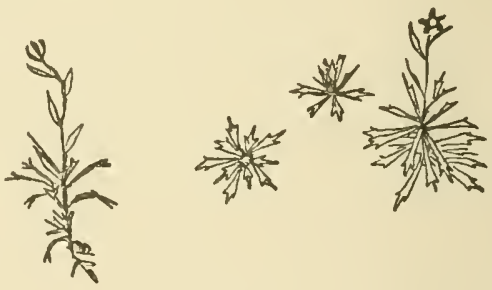
children of the Barrens is the great size of fruit and flower compared with the plant. The cranberry, the crowberry, the cloudberry, etc., produce fruit any one of which might outweigh the herb itself.

Nowhere does one get the impression that these are 
weeds, as often happens among the rank growths farther south. The flower's in the wildest profusion are generally low, always delicate and mostly in beds of a single species. The Lalique jewchry was the sensation of the Paris Exposition of 1S99. Yet here is Lalique renewed and changed for every week in the season and lavished on every square foot of a region that is a million square miles in extent.

Not a cranny in a rock but is seized on at once by the eager little gardeners in charge and made a bed of bloom, as though every inch of room were priceless. And yet Nature here exemplifies the law that our human gardeners are only lcarning: "Mass your bloom, to gain effect."

As I stood on that hill, the foreground

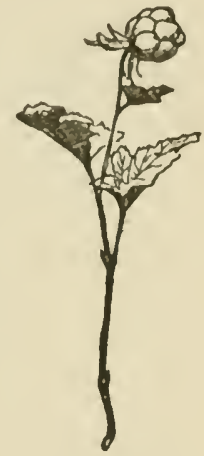

Cloudberry was a broad stretch of old gold-the shining sandy yellow of drying grass-but it was patched with large scarlet mats of arctous that would put red maple to its reddest blush. There was no Highland heather here, but there were whole hillsides of purple red vaccinium, whose leaves were but a shade less red than its luscious grape-hued fruit.

Here were white ledums in roods and acre beds; purple mairanias by the hundred acres, and, framed in lilac rocks, were rich, rank meadows of golden-green by the mile.

There were leagues and leagues of earibou moss, pale green or lilac, and a hundred others in clumps, that, seeing here the glory of the painted mosses, were sim- 
ulating their ways, though they themselves were the not truly mosses at all.

I never before saw such a realm of exquisite flowers so exquisitely displayed, and the effect at every turn throughout the land was colour, colour, colour, to as far outdo the finest autumn tints of New England as the Colorado Canyon outdoes the Hoosac Gorge. What Nature can do only in October, elsewhere, she does here all season through, as though when she set out to paint the world she began on the Barrens with a full palette and when she reached the Tropics had nothing left but green.

Thus at every step one is wading through lush grass or crushing prairie blossoms and fruits. It is so on and on; in every part of the scene, there are but few square feet that do not bloom with flowers and throb with life; yet this is the region called the Barren Lands of the North.

And the colour is an index of its higher living forms, for this is the chosen home of the Swans and Wild Geese; many of the Ducks, the Ptarmigan, the Laplongspur and Snowbunting. The blue lakes echo with the wailing of the Gulls and the eerie magic calling of the Loons. Colonies of Lemmings, Voles, or Groundsquirrels are found on every sunny slope; the Wolverine and the White Wolf find this a land of plenty, for on every side, as I stood on that high hill, were to be seen small groups of Caribou.

This was the land and these the creatures I had come to see. This was my Farthest North and this was the culmination of years of dreaming. How very 
good it seemed at the time, but how different and how infinitely more delicate and satisfying was the realisation than any of the day-dreams founded on my vision through the eyes of other men.

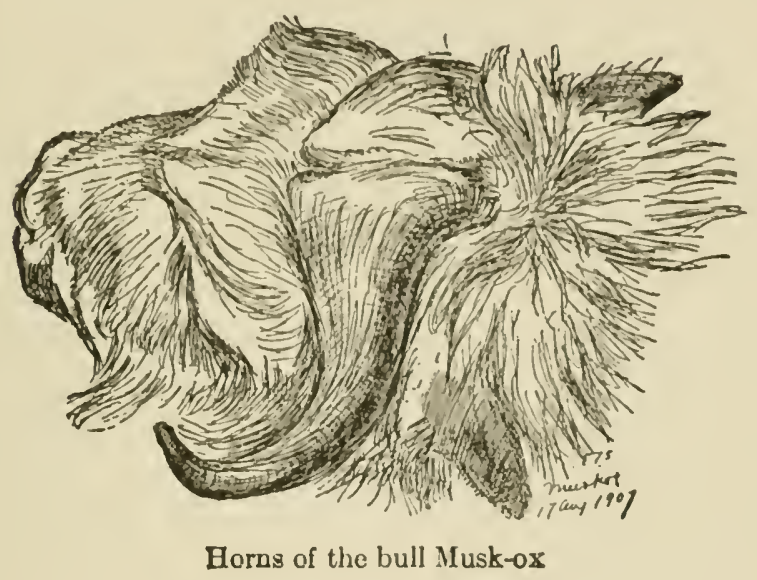




\section{CHAPTER XXXVII}

\section{FACING HOMEWARD}

ON this hill we divided, Preble and Billy going northward; Weeso and I eastward, all intent on finding a herd of Musk-ox; for this was the beginning of their range. There was one continual surprise as we journeyed-the willows that were mere twigs on Aylmer Lake increased in size and were now plentiful and as high as our heads, with stems two or three inches thick. This was due partly to the decreased altitude and partly to removal from the broad, cold sheet of Aylmer, which, with its July ice, must tend to lower the summer temperature.

For a long time we tramped eastward, among hills and meadows, with Caribou. Then, at length, turned south again and, after a 20-mile tramp, arrived in camp at 6.35, having seen no sign whatever of Musk-ox, although this is the region where Pike found them common; on July 1, 1890, at the little lake where we lunched, his party killed seven out of a considerable band.

At 9.30 that night Preble and Billy returned. They had been over Icy River, easily recognised by the thick ice still on its expansions, and on to Musk-ox Lake, without seeing any fresh tracks of a Musk-ox. As they came into camp a White Wolf sneaked away. 
Rain began at 6 and continued a heavy storm all night. In the morning it was still in full blast, so no one rose until 9.30, when Billy, starved out of his warm bed, got up to make breakfast. Soon I heard him calling: "Mr. Seton, here's a big Wolf in camp!" "Bring him in here," I said. Then a rifle-shot was heard, another, and Billy appeared, dragging a huge White Wolf. (He is now to be seen in the American Museum.)

All that day and the next night the storm raged. Even the presence of Caribou bands did not stimulate us enough to face the sleet. Next day it was dry, but too windy to travel.

Billy now did something that illustrates at once the preciousness of firewood, and the pluck, strength, and reliability of my cook. During his recent tramp he found a low, rocky hollow full of large, dead willows. It was eight miles back; nevertheless he set out, of his own free will; tramped the eight miles, that wet, blustery day, and returned in five and one-half hours, bearing on his back a heavy load, over 100 pounds of most acceptable firewood. Sixteen miles afoot for a load of wood! But it seemed well worth it as we revelled in the blessed blaze.

Next day two interesting observations were made; down by the shore I found the midden-heap of a Lemming family. It contained about four hundred pellets: their colour and dryness, with the absence of grass, showed that they dated from winter.

In the evening the four of us witnessed the tragic end of a Lap-longspur. Pursued by a ficrce Skua Gull, it unfortunately dashed out over the lake. In 
vain then it darted up and down, here and there, high and low; the Skua followed even more quickly. A second Skua came flying to help, but was not needed. With a falcon-like swoop, the pirate seized the Longspur in his bill and bore it away to be devoured at the nearest perch.

At 7.30 A. M., August 24, 1907, surrounded by scattering Caribou, we pushed off from our camp at Sand Hill Bay and began the return journey.

At Wolf-den Point we discovered a large and ancient wolf-den in the rocks; also abundance of winter sign of

Musk-ox. That day

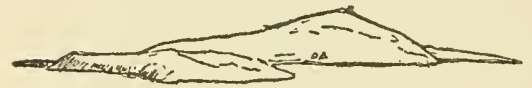

Tha-xa-koie from south we made forty miles and camped for the night on the Sand Hill Mountain in Thana-koie, the channel that joins Aylmer and ClintonColden. Here we were detained by high winds until the 28th.

This island is a favourite Caribou crossing, and Billy and Weeso had pitched their tents right on the place selected by the Caribou for their highway. Next day, while scanning the country from the top of the mount, I saw three Caribou trotting along. They swam the river and came toward me. As Billy and Weeso were in their tents having an afternoon nap, I thought it would be a good joke to stampede the Caribou on top of them, so waited behind a rock, intending to jump out as soon as they were past me. They followed the main trail at a trot, and I leaped out with "horrid yells" when they passed my rock, but now the unexpected 
happened. "In case of doubt take to the water" is Caribou wisdom, so, instead of dashing madly into the tents, they made three desperate down leaps and plunged into the deep water, then ealmly swam for the other shore, a quarter of a mile away.

This island proved a good place for small mammals. Here Preble got our first specimen of the White Lemming. Large islands usually prove better for small mammals than the mainland. They have the same conditions to support life, but being moated by the water are usually without the larger predatory quadrupeds.

The great central inland of Clinton-Colden proved the best place of all for Groundsquirrels. Here we actually found them in colonics.

On the 29th and 30 th we paddled and surveyed without ceasing and camped beyond the rapid at the exit of Clinton-Colden. The next afternoon we made the exit rapids of Casba Lake. Preble was preparing to portage them, but asked Weeso, "Can we run them?"

Weeso landed, walked to a view-point, took a squinting look and said, "Ugh!" (Yes). Preble rejoined, "All right! If he says he can, he surely can. That's the Indian of it. A white man takes risks; an Indian will not; if it is risky he'll go around." So we ran the rapids in safety.

Lighter each day, as the food was consumed, our elegant canoe went faster. When not detained by heavy seas 30 or 40 miles a day was our journey. On August 30 we made our last 6 miles in one hour and $6 \frac{1}{2}$ minutes. On September 2, in spite of head-winds, 
we made 36 miles in $8 \frac{1}{4}$ hours and in the evening we skimmed over the glassy surface of Artillery Lake, among its many beautiful islands and once more landed at our old ground-the camp in the Last Woods.

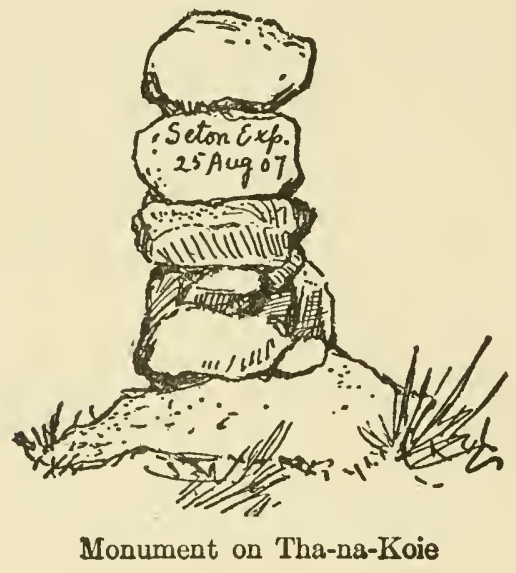




\section{CHAPTER XXXVIII}

\section{THE FIRST IVOODS}

How shall I set forth the feelings it stirred? None but the shipwrecked sailor, long drifting on the open sea, but come at last to land, ean fully know the thrill it gave us. We were like starving Indians suddenly surrounded by Caribou. Wood-timber-fuel-galore! It was hard to realise-but there it was, all about us, and in the morning we were awakened by the sweet, sweet, home-like song of the Robins in the trees, singing their "Cheerup, cheerily," just as they do it in Ontario and Connecticut. Our cache was all right; so our stock of luxuries was replenished. We now had unlimited food as well as unlimited firewood; what more could any one ask? Yet there was more. The weather was lovely; perfect summer days, and the mosquitoes were gone, yes, now actually nets and flybars were discarded for good. On every side was animal life in abundance; the shimmering lake with its Loons and islands would fit exactly the Indian's dream of the heavenly hunting-grounds. These were the happy halcyon days of the trip, and we stayed a week to rest and revel in the joys about us.

In the morning I took a long walk over the familiar hills; the various skeletons we had left were picked bare, evidently by Gulls and Ravens, as no bones were broken and even the sinews were left. There were many fresh 
tracks of single Caribou going here and there, but no trails of large bands. I sent Weeso off to the Indian village, two miles south. He returned to say that it was deserted and that, therefore, the folk had gone after the Caribou, which doubtless were now in the woods south of Artillery Lake. Again the old man was wholly astray in his Caribou forecast.

That night there was a sharp frost; the first we had had. It made nearly half an inch of ice in all kettles. Why is ice always thickest on the kettles? No doubt because they hold a small body of very still water surrounded by highly conductive metal.

Billy went "to market" yesterday, killing a nice, fat little Caribou. This morning on returning to bring in the rest of the meat we found that a Wolverine had been there and lugged the most of it away. The tracks show that it was an old one accompanied by one or maybe two young ones. We followed them some distance but lost all trace in a long range of rocks.

The Wolverine is one of the typical animals of the far North. It has an unenviable reputation for being the greatest plague that the hunter knows. Its habit of following to destroy all traps for the sake of the bait is the prime cause of man's hatred, and its cleverness in eluding his efforts at retaliation give it still more importance.

It is, above all, the dreaded enemy of a cache, and as already seen, we took the extra precaution of putting our caches up trees that were protected by a necklace of fishhooks. Most Northern travellers have regaled us with tales of this animal's diabolical clever- 


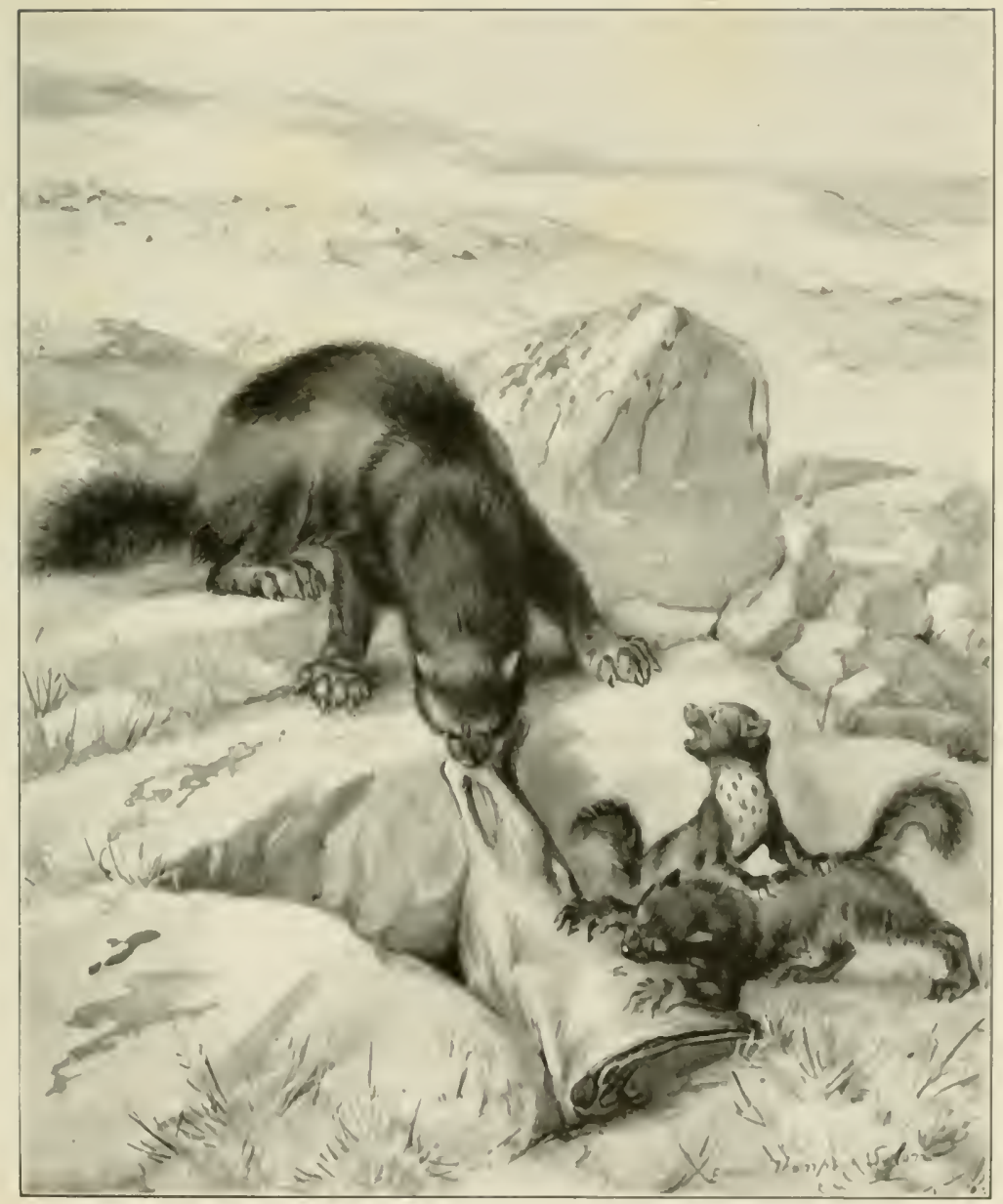

A Wolverine and her cubs stealing our Caribun meat 

ness and wickelness. It is fair to say that the malice, at least, is not proven; and there is a good side to Wolverine character that should be emphasized; that is, its nearly ideal family life, coupled with the heroic bravery of the mother. I say "nearly" ideal, for so far as I can learn, the father does not assist in rearing the young. But all observers agree that the mother is absolutely fearless and devoted. More than one of the hunters have assured me that it is safer to molest a mother Bear than a mother Wolverine when accompanied by the cubs.

Bellalise, a half-breed of Chipewyan, told me that twice he had found Wolverine dens, and been seriously endangered by the mother. The first was in midMay, 190t, near Fond du Lac, north side of Lake Athabaska. He went out with an Indian to bring in a skiff left some miles off on the shore. He had no gun, and was surprised by coming on an old Wolverine in a slight hollow under the boughs of a green spruce. She rushed at him, showing all her tecth, her eyes shining blue, and uttering sounds like those of a Bear. The Indian boy hit her once with a stick, then swung himself out of danger up a tree. Bellalise ran off after getting sight of the young ones; they were four in number, about the size of a Muskrat, and pure white. Their eyes were open. The nest was just such as a dog might make, only six inches deep and lined with a little dry grass. Scattered around were bones and fur, chiefly of Rabbits.

The second occasion was in 1905 , within three miles of Chipewyan, and, as before, about the middle of May. 
The nest was much like the first one; the mother saw him coming, and charged furiously, uttering a sort of coughing. He shot her dead; then captured the young and examined the nest; there were three young this time. They were white like the others.

Not far from this camp, we found a remarkable midden-yard of Lemmings. It was about 10 feet by

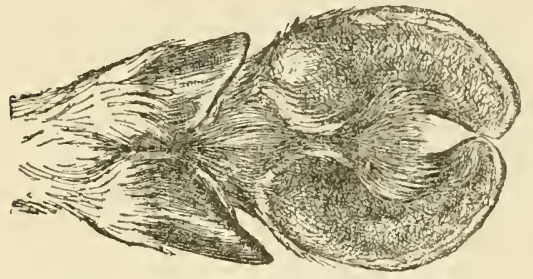

Foot of a Barren-Ground Caribou 40 feet, the ground within the limits was thickly strewn with pellets, at the rate of 14 to the square inch, but nowhere were they piled up. At this reckoning, there were over 800,000 , but there were also many outside, which probably raised the number to 1,000,000. Each pellet was long, brown, dry, and curved, i.e., the winter type. The place, a high, dry, very sheltered hollow, was evidently the winter range of a colony of Lemmings that in summer went elsewhere, I suppose to lower, damper grounds.

After sunset, September 5, a bunch of three or four Caribou trotted past the tents between us and the Lake, 200 yards from us; Billy went after them, as, thanks to the Wolverine, we were out of meat, and at one shot secured a fine young buck.

His last winter's coat was all shed now, his ears were turning white and the white areas were expanding on feet and buttocks; his belly was pure white.

On his back and rump, chiefly the latter, were the 
scars of 121 bots. I could not see that they affected the skin or hair in the least.

Although all of these Caribou scem to have the normal foot-click, Preble and I worked in vain with the fect of this dearl one to make the sound; we could not by any combination of movement, or weight or simulation of natural conditions, produce anything like a "click."

That same day, as we sat on a hill, a cow Caribou came curiously toward us. At 100 yards she circled slowly, gazing till she got the wind 150 yards to one side, then up went her tail and off she trotted a quarter of a mile, but again drew nearer, then circled as before till a second time the wind warned her to flee. This she did three or four times before trotting away; the habit is often seen.

Next afternoon, Billy and I saw a very large buck; his neck was much swollen, his beard flowing and nearly white. He sighted us afar, and worked north-west away from us, in no great alarm. I got out of sight, ran a mile and a half, headed him off, then came on him from the north, but in spite of all I could do by running and yelling, he and his band ( 3 cows with 3 calves) rushed galloping between me and the lake, 75 yards away. He was too foxy to be driven back into that suspicious neighbourhood.

Thus we had fine opportunities for studying wild life. In all these days there was only one unfulfilled desire: I had not seen the great herd of Caribou returning to the woods that are their winter range.

This herd is said to rival in numbers the Buffalo herds of story, to reach farther than the eye can see, 
and to be days in passing a given point; but it is utterly erratic. It might arrive in early September. It was not sure to arrive until late October, when the winter had begun. This year all the indications were that it would be late. If we were to wait for it, it would mean going out on the ice. For this we were wholly unprepared. There were no means of getting the necessary dogs, sleds, and fur garments; my business was calling me back to the East. It was useless to discuss the matter, decision was forced on me. Therefore, without having seen that great sight, one of the world's tremendous zoological spectacles-the march in one body of millions of Caribou-I reluctantly gave the order to start. On September 8 we launched the Ann Seton on her homeward voyage of 1,200 upstream miles.

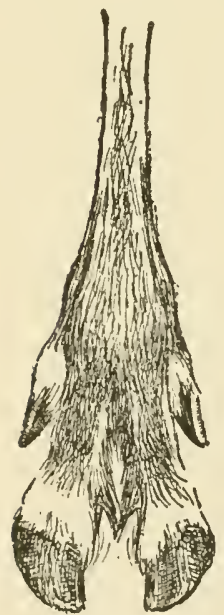

Front left foot of caribou showing position of backward and forward stroke when swimming

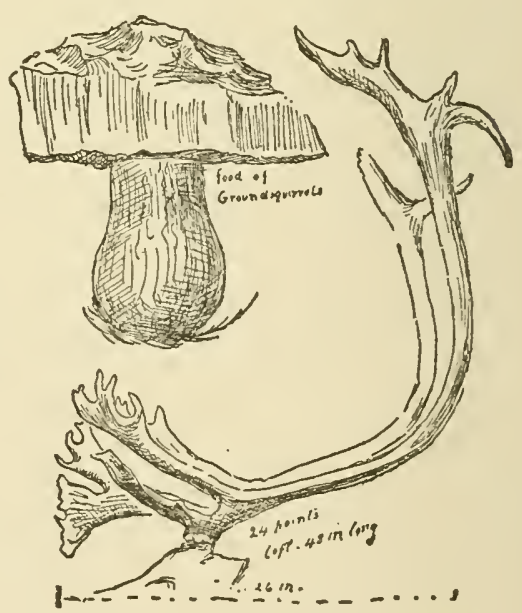

Food of groundsquirrels. Antlers of Caribou 


\section{CHAPTER XXXIX}

\section{FAREWELI, TO THE CARIBOU}

ALL along the shore of Artillery Lake we saw small groups of Caribou. They were now in fine coat; the manes on the males were long and white and we saw two with cleaned antlers; in one these were of a brilliant red, which I suppose meant that they were cleaned that day and still bloody.

We arrived at the south end of Artillery Lake that night, and were now again in the continuous woodswhat spindly little stuff it looked when we left it; what superb forest it looked now-and here we bade goodbye to the prairies and their Caribou.

Now, therefore, I shall bricfly summarise the information I gained about this notable creature. The species ranges orer all the treeless plains and islands of Aretic America. While the great body is migratory, there are scattered individuals in all parts at all scasons. The main body winter's in the sheltered southern third of the range, to avoid the storms, and moves north in the late spring, to avoid the plagues of deer-flies and mosquitocs. The former are found chiefly in the woods, the latter are bad everywhere; by travelling against the wind a certain measure of relief is secured, northerly winds prevail, so the Caribou are kept travelling northward. When there is no wind, the instinctive habit of migration doubtless directs the general movement. 
How are we to form an idea of their numbers? The only way seems to be by watching the great migration to its winter range. For the reasons already given this was impossible in my case, therefore, I array some of the known facts that will evidence the size of the herd.

Warburton Pike, who saw them at Mackay Lake, October" 20, 1859, says: "I cannot believe that the herds [of Buffalo] on the prairie ever surpassed in size La Foule (the throng) of the Caribou. La Foule had really come, and during its passage of six days I was able to realize what an extraordinary number of these animals still roam the Barren Grounds."

From figures and facts given me by H. T. Munn, of Brandon, Manitoba, I reckon that in three weeks following July 25, 1892, he saw at Artillery Lake (N. latitude $62 \frac{1}{2}^{\circ}$, W. Long. $112^{\circ}$ ) not less than 2,000,000 Caribou travelling southward; he calls this merely the advance guard of the great herd. Colonel Jones (Buffalo Jones), who saw the herd in October at Clinton-Colden, has given me personally a description that furnishes the basis for an interesting calculation of their numbers.

He stood on a hill in the middle of the passing throng, with a clear view ten miles each way and it was one army of Caribou. How much further they spread, he did not know. Sometimes they were bunched, so that a hundred were on a space one hundred feet square; but often there would be spaces equally large without any. They averaged at least one hundred Caribou to the acre; and they passed him at the rate of about three miles an hour. He did not know how long they 
were in passing this point; but at another place they were four days, and travelled day and night. The whole world seemed a moving mass of Caribou. He got the impression at last that they were standing still and he was on a rocky hill that was rapidly running through their hosts.

Even halving these figures, to keep on the safe side, we find that the number of Caribou in this army was ovel $25,000,000$. Yet it is possible that there are several such armies. In which case they must indeed outnumber the Buffalo in their palmiest epoch. So much for their abundance to-day. To what extent are they being destroyed? I looked into this question with care.

First, of the Indian destruction. In 1812 the Chipewyan population, according to Kiennicott, was 7,500. Thomas Anderson, of Fort Smith, showed me a census of the Mackenzic River Indians, which put them at 3,961 in 1884. Official returns of the Canadian government give them in 1905 at 3,411 , as follows:

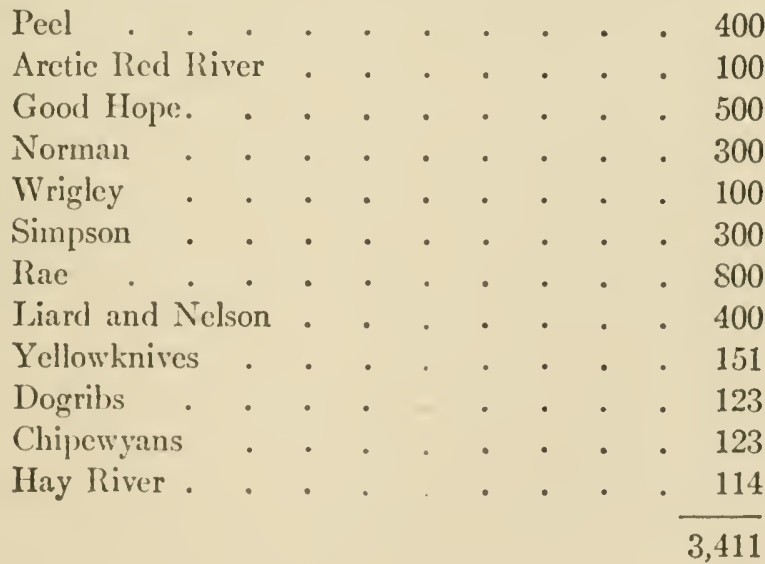


Of these the Hay River and Liard Indians, numbering about 500, can scarcely be considered Cariboueaters, so that the Indian population feeding on Caribou to-day is about 3,000 , less than half what it was 100 years ago.

Of these not more than 600 are hunters. The traders generally agree that the average annual kill of Caribou is about 10 or 20 per man, not more. When George Sanderson, of Fort Resolution, got 75 one year, it was the talk of the country; many got none. Thus 20,000 per annum killed by the Indians is a liberal estimate to-day.

There has been so much talk about destruction by whalers that I was careful to gather all available information. Several travellers who had visited Hershell Island told me that four is the usual number of whalers that winter in the north-east of Point Barrow. Sometimes, but rarely, the number is increased to eight or ten, never more. They buy what Caribou they can from Eskimo, sometimes aggregating 300 or 400 carcasses in a winter, and would use more if they could get them, but they cannot, as the Caribou herds are then far south. This, E. Sprake Jones, William Hay, and others, are sure represents fairly the annual destruction by whalers on the north coast. Only one or two vessels of this traffic go into Hudson's Bay, and these with those of Hershell are all that touch Caribou country, so that the total destruction by whalers must be under 1,000 head per annum.

The Eskimo kill for their own use. Franz Boas ("Handbook of American Indians") gives the number 
of Eskimo in the central region at 1,100. Of these not more than 300 are hunters. If we allow their destruction to equal that of the 600 Indians, it is liberal, giving a total of 40,000 Caribou killed by native hunters. As the whites rarely enter the region, this is practically all the destruction by man. The annual increase of 30,000,000 Caribou must be several millions and would so far overbalance the hunter toll that the latter cannot make any permanent difference.

There is, moreover, good evidence that the native destruction has diminished. As already seen, the tribes which hunt the Barren-Ground Caribou, number less than one-half of what they did 100 years ago. Since then, they have learned to use the rifle, and this, I am assured by all the traders, has lessened the destruction. By the old method, with the spear in the water, or in the pound trap, one native might kill 100 Caribou in one day, during the migrations; but these methods called for wooderaft and were very laborious. The rifle, being much easier, has displaced the spear; but there is a limit to its destruction, especially with cartridges at five cents to seven cents each, and, as already seen, the hunters do not average 20 Caribou each in a year.

Thus, all the known facts point to a greatly diminished slaughter to-day when compared with that of 100 years ago. This, then, is my summary of the BarrenGround Caribou between the Mackenzie River and Hudson's Bay. They number over 30,000,000, and may be double of that. They are in primitive conditions and probably never more numerous than now. 
The native destruction is less now than formerly and never did make any perceptible difference.

Finally, the matter has by no means escaped the attention of the wide-awake Canadian government represented by the Minister of the Interior and the Royal North-west Mounted Police. It could not be in better hands; and there is no reason to fear in any degree a repetition of the Buffalo slaughter that disgraced the plains of the United States.

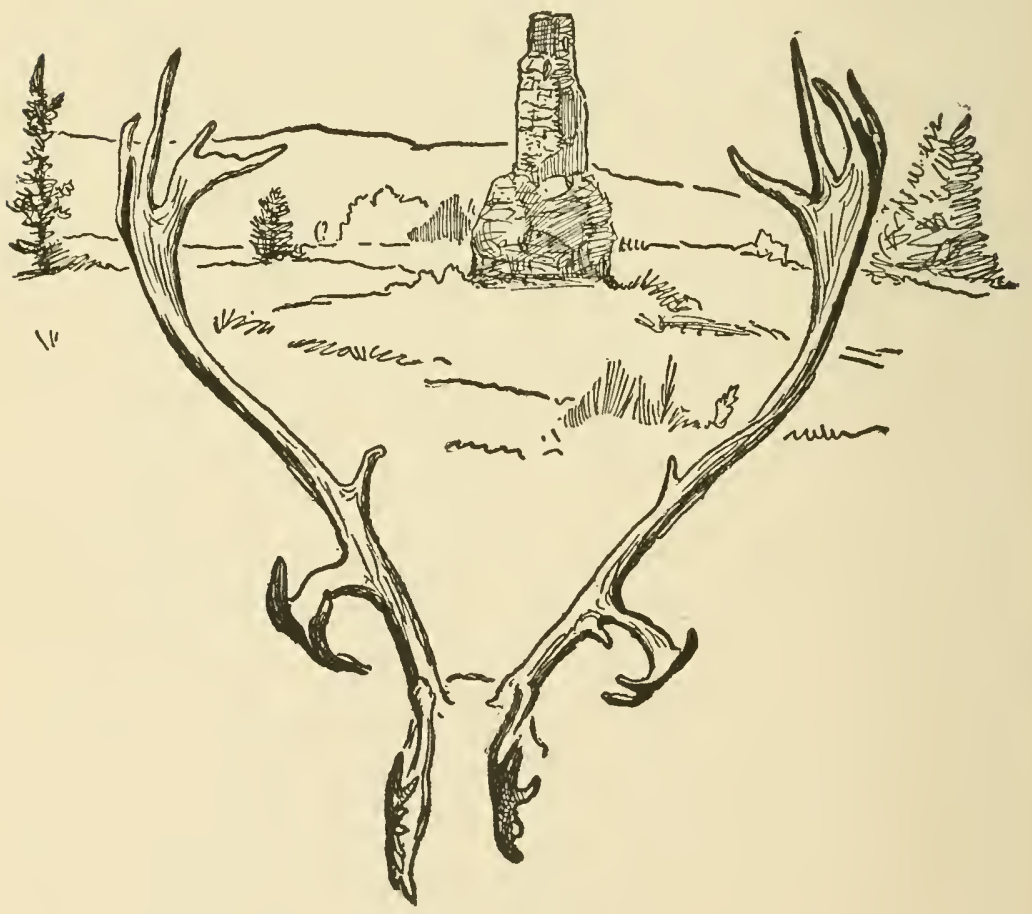

Barren-Ground Caribou

OId Fort Reliance in hackground, September 13, 1907 


\section{CHAPTER XL}

\section{OLD FORT RELIANCE TO FORT RESOLUTION}

ALL night the storm of rain and snow raged around our camp on the south shore of Artillery Lake, but we were up and away in the moming in spite of it. That day we covered five portages (they took two days in coming out). Next day we crossed Lake Harry and camped three-quarters of a mile farther on the long portage. Next day, September 11, we camped (still in storm) at the Lobstick Landing of Great Slave Lake. How tropically rich all this vegetation looked after the "Land of little sticks." Rain we could face, but high winds on the big water were dangerous, so we were storm-bound until September 14, when we put off, and in two hours were at old Fort Reliance, the winter quarters of Sir George Back in 1S33-4. In the Far North the word "old" means "abandoned" and the fort, abandoned long ago, had disappeared, except the great stone chimneys. Around one of these that intrepid explorer and hunter-Buffalo Jones-had built a shanty in 1897 . There it stood in fairly good condition, a welcome shelter from the storm which now set in with redoubled fury. We soon had the big fireplace aglow and sitting there in comfort that we owed to him, and surrounded by the skeletons of the Wolves that he had killed about the door in that fierce winter time, we 
drank in hot and copious tea the toast: "Long life and prosperity to our host so far away, the brave old hunter, Buffalo Jones."

The woods were beautiful and abounded with life, and the three days we spent there were profitably deroted to collecting, but on September 17 we

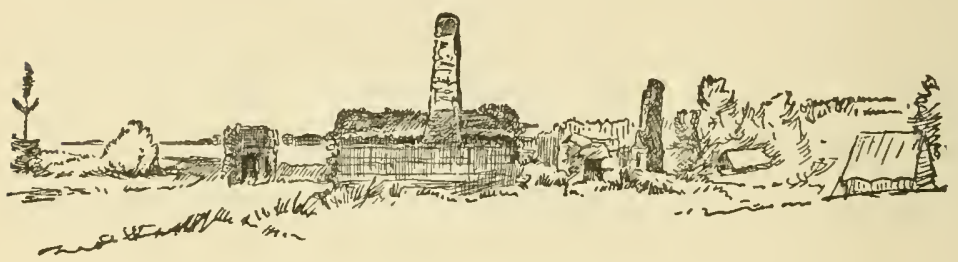

Old Fort Reliance from north

crossed the bay, made the short portage, and at night camped 32 miles away, on the home track.

Next morning we found a camp of Indians down to the last of their food. We supplied them with flour and tobacco. They said that no Caribou had come to the Lake, showing how erratic is the great migration.

In the afternoon we came across another band in still harder luck. They had nothing whatever but the precarious catch of the nets, and this was the offseason. Again we supplied them, and these were among the unexpected emergencies for which our carefully guarded supplies came in.

In spite of choppy seas we made from 30 to 35 miles a day, and camped on Tal-thel-lay the evening of September 20. That night as I sat by the fire the moon rose in a clear sky and as I gazed on her calm bright disc something seemed to tell me that at that 
moment the dear ones far away were also looking on that radiant face.

On the 21st we were storm-bound at Et-then Island, but utilised the time collecting. I gathered a lot of roots of Pulsatilla and $C a-$ lypso. Here Billy amused us by eatching Wiskajons in

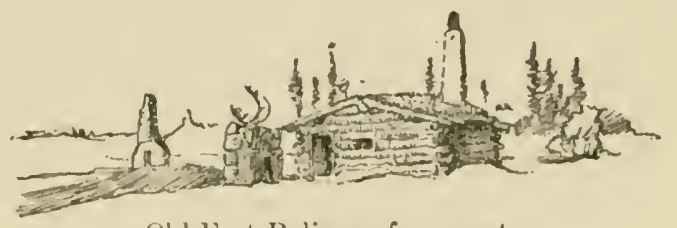

Old lort Reliance from east

an old-fashioned springle that dated from the days when guns were unknown; but the eaptured birds came back fearlessly each time after being released.

All that day we had to lie about eamp, keeping under cover on account of the rain. It was dreary work listening to the surf ceasclessly pounding the shore and realising that all these precious hours were needed to bring us to Fort

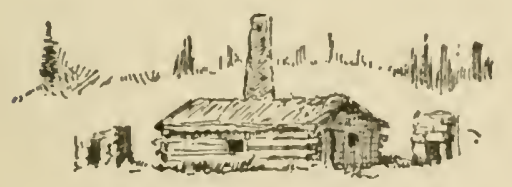

Old Fort Reliance from south

Resolution, where the steamer was to meet us on the 2.5th.

On the $23 \mathrm{~d}$ it was calmer and we got away in the gray dawn at 5.45. We were now in Weeso's country, and yet he ran us into a singular pocket that I have called Weeso's Trap-a straight glacial groove a mile long that came to a sudden end and we had to go back that mile.

The old man was much mortified over his blunder, but he did not feel half so badly about it as I did, for every hour was precious now. 
What a delight it was to feel our canoe skimming along under the four paddles. Three times as fast we trav lled now as when we came out with the bigger boat; $5 \frac{1}{2}$ miles an hour was frequently our rate and

when we camped that

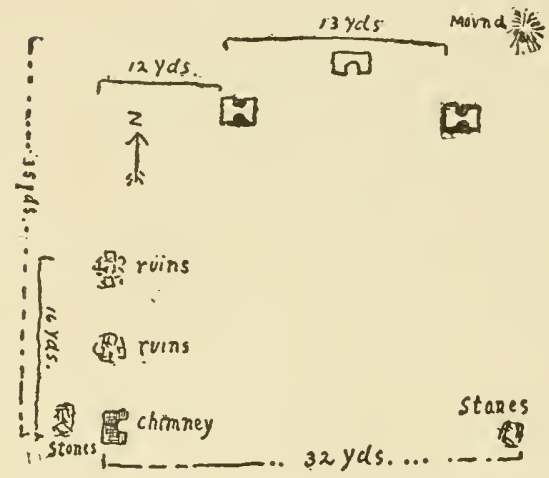

Plan of old Fort Reliance

night we had covered 47 miles since dawn.

On Kahdinouay we camped and again a storm arose to pound and bluster all night. In spite of a choppy sea next day we reached the last small island before the final crossing; and here, perforce, we stayed to await a calmer sea. Later we heard that during this very storm a canoe-load of Indians attempted the crossing and upset; none were swimmers, all were drowned.

We were not the only migrants hurrying southward. Here for the first time in my life I saw Wild Swans, six in a flock. They were heading southward and flew not in very orderly array, but ever changing, occasionally forming the triangle after the manner of Geese. They differ from Geese in flapping more slowly, from White Cranes in flapping faster, and seemed to vibrate only the tips of the wings. This was on the $23 \mathrm{~d}$. Next day we saw another flock of seven; I suppose that in each case it was the old one and young of the year. 
As they flew they uttered three different notes: a deep horn-like "too" or "coo," a higher pitched "coo," and a warble-like "tootle-tootle," or sometimes simply "tcetee." Maybe the last did not come from the Swans, but no other birds were near; I suppose that these three styles of notes came from male, female, and young.

Next morning 7 flocks of Swans flew overhead toward the south-west. They totalled $46 ; 12$ were the most in one flock. In this large flock I

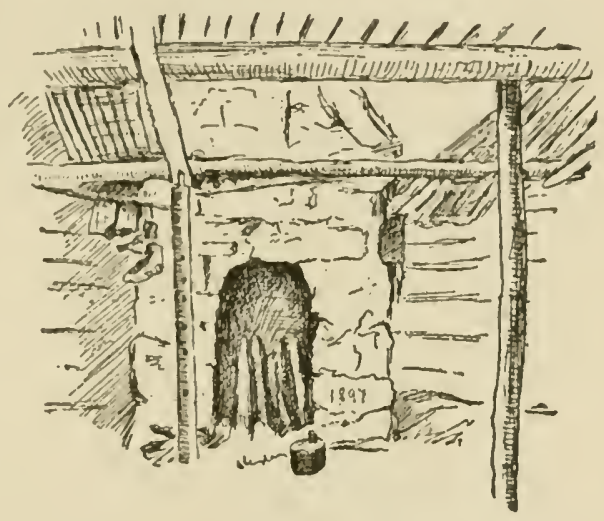

Back's chimney in Buffalo Jones's cabin

saw a quarrel. No. 2 turned back and struck No. 3, his long neck bent and curled like a snake, both dropped downward several feet then 3,4 and 5 left that flock. I suspect they were of another family.

But, later, as we entered the river mouth we had a thrilling glimpse of Swan life. Flock after flock came in view as we rounded the rush beds; 12 flocks in all we saw, none had less than 5 in it, nearly 100 Swans in sight at once, and all rose together with a mighty flapping of strong, white wings, and the chorus of the insignificant "too-too-tees" sailed farther southward, probably to make the great Swan tryst on Hay River. 
No doubt these were the same 12 flocks as those observed on the previous days, but still it rejoiced my heart to see even that many. I had feared that the species was far gone on the trail of the Passenger Pigeon.

But this is anticipating. We were camped still on the island north of the traverse, waiting for possible

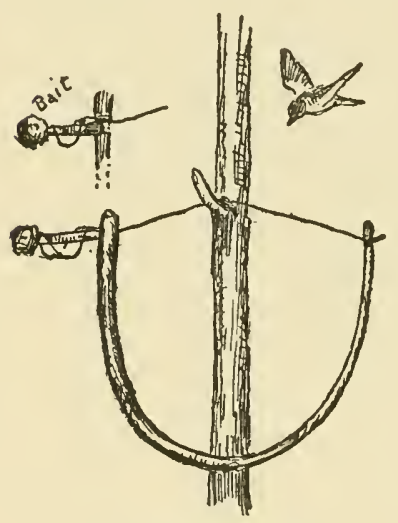

Billy's springle water. All day we watched in vain, all night the surf kept booming, but at three in the morning the wind dropped, at four it was obviously calmer. I called the boys and we got away before six; dashing straight south in spite of rolling seas we crossed the 15-mile stretch in $3 \frac{3}{4}$ hours, and turning westward reached Stony Island by noon. Thence southward through ever calmer water our gallant boat went spinning, reeling off the level miles up the river channel, and down again on its south-west branch, in a glorious red sunset, covering in one day the journeys of four during our outgoing, in the supposedly far speedier York boat. Faster and faster we seemed to fly, for we had the grand incentive that we must catch the steamer at any price that night. Weeso now, for the first time, showed up strong; knowing every yard of the way he took advantage of every swirl of the river; in and out among the larger islands we darted, and when we 
should have stopped for the night no man said "Stop," but harder we paddled. We could smell the steamer smoke, we thought, and pietured her eaptain cagrerly

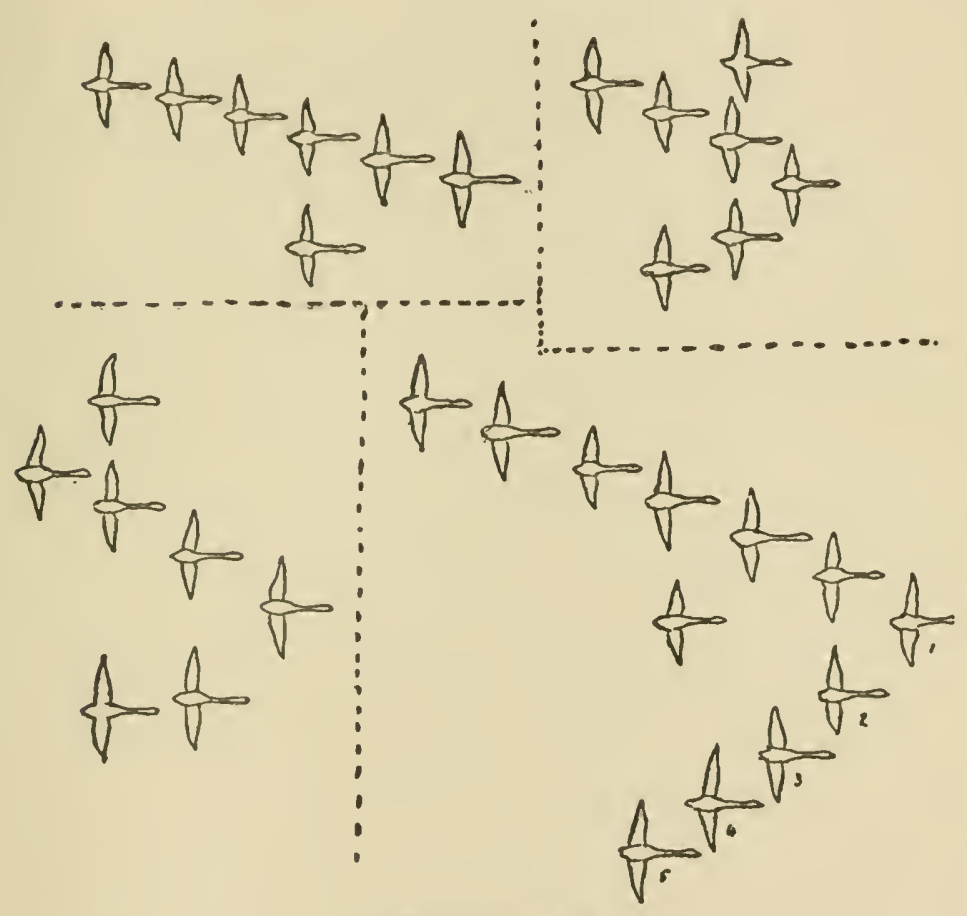

Flocks of Swans

seanning the offing for our flying canoe; it was most inspiring and the Ann Seton jumped up to 6 miles an hour for a time. So we went; the night came down, but far away were the glittering lights of Fort Resolution, and the steamer that should end our toil. How cheering. The skilly pilot and the lusty paddler 
slacked not-40 miles we had come that day-and when at last some 49 , nearly 50 , paddled miles brought us stiff and weary to the landing it was only to learn that the steamer; notwithstanding bargain set and agreed on, had gone south two days before. 


\section{CHAPTER XLI}

\section{GOING UP 'THE LOWER SLAVE}

What we thought about the steamboat official who was responsible for our dilemma we did not need to put into words; for every one knew of the bargain and its breach: nearly every one present had protested at the time, and the hardest things I felt like saying were mild compared with the things already said by that official's own colleagues. But these things were forgotten in the hearty greetings of friends and bundles of letter's from home. It was eight o'clock, and of course black night when we landed; yet it was midnight when we thought of sleep.

Fort Resolution is always dog-town; and now it seemed at its worst. When the time came to roll up in our blankets, we were fully possessed of the camper's horror of slceping indoors; but it was too dark to put up a tent and there was not a square foot of ground anywhere near that was not polluted and stinking of "dog-sign," so very unwillingly I broke my long spell of sleeping out, on this 131st day, and passed the night on the floor of the Hudson's Bay Company house. I had gone indoors to avoid the "(log-sign" and next morning found, alas, that I had been lying all night on "cat-sign."

I say lying; I did not sleep. The closeness of the room, in spite of an open window, the novelty, the 
smells, combined with the excitement of letters from home, banished sleep until morning came, and, of course, I got a bad cold, the first I had had all summer.

Here I said "good-bye" to old Weeso. He grinned affably, and when I asked what he would like for a present said, "Send me an axe like yours." There were three things in my outfit that aroused the cupidity of nearly every Indian, the Winchester rifle, the Peterboro canoe and the Marble axe, "the axe that swallows its face." Weeso had a rifle, we could not spare or send him a canoe, so I promised to send him the axe. Post is slow, but it reached him six months later and I doubt not is even now doing active service.

Having missed the last steamer, we must go on by canoe. Canoeing up the river meant "tracking" all the way; that is, the canoe must be hauled up with a line, by a man walking on the banks; hard work needing not only a strong, active man, but one who knows the river. Through the kindness of J. McLeneghan, of the Swiggert Trading Company, I was spared the horrors of my previous efforts to secure help at Fort Resolution, and George Sanderson, a strong young half-breed, agreed to take me to Fort Smith for $\$ 2.00$ a day and means of returning. George was a famous hunter and fisher, and a "good man" to travel. I marked his broad shoulders and sinewy, active form with joy, especially in view of his reputation. In one respect he was different from all other half-breeds that I ever knew-he always gave a straight answer. Ask an ordinary half-breed, or western white man, indeed, 
how far it is to such a point, his reply commonly is "Oh, not so awful far," or "It is quite a picce," or "It aint such a hell of a ways," conveying to the stranger no shadow of idea whether it is a hundred yards, a mile, or a wcek's travel. Again and again when Sanderson was asked how far it was to a given place, he would pause and say, "Three miles and a half," or "Little more than cight miles," as the case might be. The usual half-breed when asked if we could make such a point by noon would say "Maybe. I don't know. It is quite a piece." Sanderson would say, "Yes," or "No, not by two miles," according to circumstances; and his information was always correct; he knew the river "like a book."

On the afternoon of September 27 we left "Dogtown" with Sanderson in Wceso's place and began our upward journey. George proved as good as his reputation. The way that active fellow would stride along the shore, over logs and brush, around fallen trees, hauling the canoe against stream some three or four miles an hour was perfectly fine; and each night my heart was glad and sang the old refrain, "A day's march nearer home."

The toil of this tracking is second only to that of portageing. The men usually relieve each other every 30 minutes. So Billy and George were the team. If I were going again into that country and had my choice these two again would be my crew.

Once or twice I took the track-line myself for a quarter of an hour, but it did not appeal to me as a per- 
manent amusement. It taught me one thing that I did not suspect, namely, that it is much harder to haul a canoe with three inches of water under her kecl than

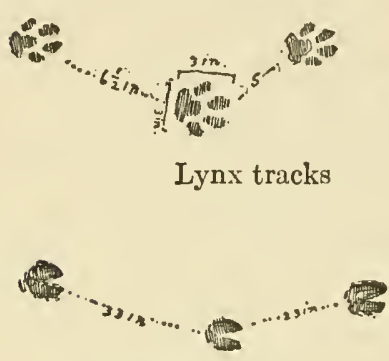

Musk-ox tracks
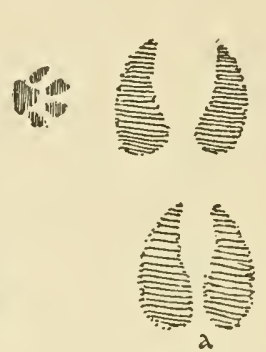
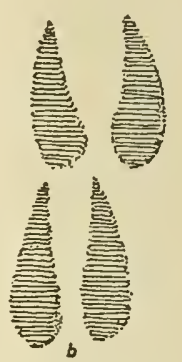

a. Moose track in rocky country $b$. The same in muddy country

with three fect. In the former case, the attraction of the bottom is most powerful and evident. The experience also explained the old sailor phrase about the vessel feeling the bottom: this I had often heard, but never before comprehended.

All day we tracked, covering 20 to 25 miles between camps and hourly making observations on the wild life of the river. Small birds and mammals were evidently

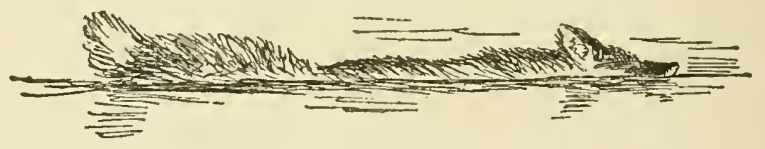

[Fox swimming Slave River. October 4, 1907

much more abundant than in spring, and the broad, muddy, and sandy reaches of the margin were tracked over by Chipmunks, Weasels, Foxes, Lynxes, Bear, and Moose. 
A Lynx, which we surprised on a sand-bar, took to the water without hesitation and swam to the mainland. It went as fast as a dog, but not nearly so fast as a Caribou. $A$ large Fox that we saw crossing the river proved very inferior to the Lynx in swimming speed.

The two portages, Ennuyeux and Détour, were duly passed, and on the morning of October 3 , as we travelled, a sailboat hove into sight. It held Messis. Thomas Christy, C. Harding, and Stagg. We were now within $1 \frac{1}{2}$ days of Fort Smith, so I took advantage of the opportunity to send Sanderson back. On the evening of the $3 \mathrm{~d}$ we came to Salt River, and there we saw Pierre Squirrel with his hundred dogs and at 1 р. м., October 4, arrived at Fort Smith.
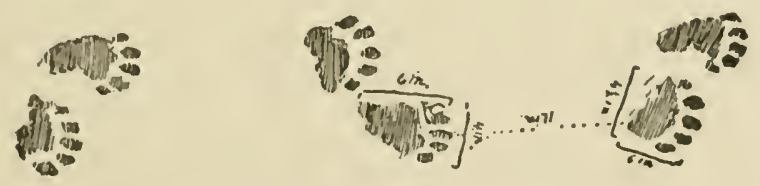

Tracks of Blackbear, Athabaska Rivor 


\section{CHAPTER XLII}

\section{FORT SMITH AND THE TUG}

HERE again we had the unpleasant experience of sleeping indoors, a miserable, sleepless, stifling night, followed by the inevitable cold.

Next day we rode with our things over the portage to Smith Landing. I had secured the tug Ariel to give us a lift, and at 7 P. M., October 5, pulled out for the next stretch of the river, ourselves aboard the tug, the canoe with a cargo towed behind.

That night we slept at the saw-mill, perforce, and having had enough of indoors, I spread my blankets outside, with the result, as I was warned, that every one of the numerous dogs came again and again, and passed his opinion on my slumbering form. Next night we selected an island to camp on, the men did not want to stay on the mainland, for "the woods are full of mice and their feet are so cold when they run over your face as you sleep." We did not set up our tents that time but lay on the ground; next morning at dawn, when I looked around, the camp was like a country graveyard, for we were all covered with leaves, and each man was simply a long mound. The dawn came up an ominous rose-red. I love not the rosy dawn; a golden dawn or a chill-blue dawn is happy, but I fear the dawn of rose as the red head-light of a 


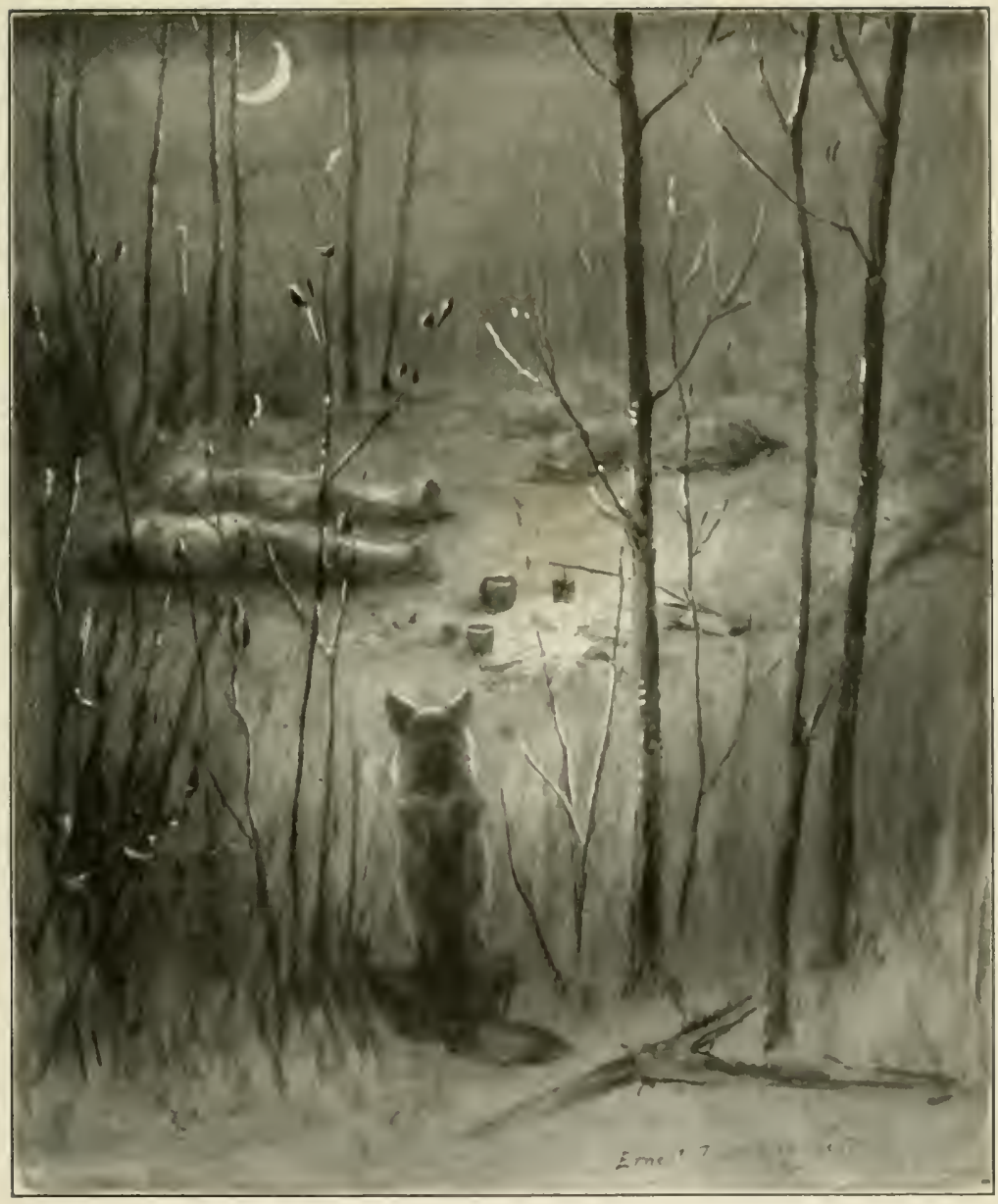

The camp was like a country graveyard 

storm. It came; by 8.30 the rain had set in and steadily fell all day.

The following morning we had our first accident. The steamer with the loaded eanoe behind was rushing up a rapid. A swirl of water upset the canoe, and all our large packs were afloat. All were quickly recovered except a bag of salted skins. These sank and were seen no mole.

On October 9 we arrived at Fort Chipewyan. As we drew near that famous place of water-fowl, the long strings and massed flocks of various geese and ducks grew more and more plentiful; and at the Fort itself we found their metropolis. The Hudson's Bay Company had killed and salted about 600 Waveys or Snow Geese; cach of the Loutit families, about 500; not less than 12,000 Wareys will be salted down this fall, besides Honkers, White-fronts and Ducks. Each year they reckon on about 10,000 Waveys, in poor years they take 5,000 to 6,000 , in fat years 15,000 . The Snow and White-fronted Geese all had the white parts of the head more or less stained with orange. Only one Blue Goose had been taken. This I got; it is a westernmost record. No Swans had been secured this year; in fact, I am told that they are never taken in the fall because they never come this way, though they visit the east end of the lake; in the spring they come by here and about 20 are taken each year. Chipewyan was Billy Loutit's home, and the family gave a dance in honour of the wanderer's return. Here I secured a tall half-breed, Gregoire Daniell, usually known as "Bellalise," to go with me as far as Athabaska Landing. 
There was no good reason why we should not leave Chipewyan in three hours. But the engineer of my tug had run across an old friend; they wanted to have a jollification, as of course the engine was "hopelessly out of order." But we got away at 7 next day-my four men and the tug's three. At the wheel was a half-breed-David MacPherson-who is said to be a natural-born pilot, and the best in the country. Although he never was on the Upper Slave before, and it is an exceedingly difficult stream with its interminable, intricate, shifting shallows, crooked, narrow channels, and impenetrable muddy currents, his "nose for water" is so good that he brought us through at full speed without striking once. Next time he will be qualified to do it by night.

In the grove where we camped after sundown were the teepee and shack of an Indian (Chipewyan) Brayno (probably Brénaud). This is his hunting and trapping ground, and has been for years. No one poaches on it; that is unwritten law; a man may follow a wounded animal into his neighbour's territory, but not trap there. The nearest neighbour is 10 miles off. He gets 3 or 4 Silver Foxes every year, a few Lynx, Otter, Marten, etc.

Bellalise was somewhat of a character. About 6 feet 4 in height, with narrow, hollow chest, very large hands and feet and a nervous, restless way of flinging himself about. He struck me as a man who was killing himself with toil beyond his physical strength. He was strongly recommended by the Hudson's Bay Company people as a "good man." I liked his face and manners, 
he was an intelligent companion, and I was glad to have secured him. At the first and second camps he worked hard. At the next he ceased work suddenly and went aside; his stomach was upset. A few hours afterwards he told me he was fecling ill. The engineer, who wanted him to cut wood, said to me, "That man is shamming." My reply was short: "You have known him for months, and think he is shamming; I have known him for hours and I know he is not that kind of a man."

He told me next morning, "It's no use, I got my breast crushed by the tug a couple of weeks ago, I have no strength. At Fort McKay is a good man named Jiarobia, he will go with you."

So when the tug left us Bellalise refunded his advance and returned to Chipewyan. He was one of those that made me think well of his people; and his observations on the wild life of the country showed that he had a tongue to tell, as well as eyes to see.

That morning, besides the calls of Honkers and Waveys we heard the glorious trumpeting of the White Crane. It has less rattling croak and more whoop than that of the Brown Crane. Bellalise says that every year a few come to Chipewyan, then go north with the Waveys to breed. In the fall they come back for a month; they are usually in flocks of three and four; two old ones and their offspring, the latter known by their brownish colour. If you get the two old ones the young ones are easily killed, as they keep flying low over the place.

Is this then the secret of its disappearance? and is it 
on these far breeding grounds that man has proved too hard?

At Lobstick Point, 2 P. x., October 13, the tug turned back and we three continued our journey as before, Preble and Billy taking turns at tracking the canoe.

Next day we reached Fort McKay and thus marked another important stage of the journey. 


\section{CHAPTER XLIII}

\section{FORT MCKAY ANI) JIAROBIA}

Fort McKar was the last point at which we saw the Chiperyan style of teepee, and the first where the Cree appeared. But its chief interest to us lay in the fact that it was the home of Jiarobia, a capable river-man who wished to go to Athabaska Landing. The first thing that struck us about Jiarobia-whose dictionary name by the way is Elzear Robillard-was that his house had a good roof and a large pile of wood ready cut. These were extremely important indications in a land of improvidence. Robillard was a thin, active, half-breed of very dark skin. He was willing to go for $\$ 2.00$ a day the round trip (1S days) plus food and a boat to return with. But a difficulty now appeared; Madame Robillard, a tall, dark half-breed woman, objected: "Elzear had been away all summer, he should stay home now." "If you go I will run off into the backwoods with the first wild Indian that wants a squaw," she threatened. "Now," said Rob, in choice English, "I am up against it." She did not understand English, but she could read looks and had some French, so I took a hand.

"If Madame will consent I will advance $\$ 15.00$ of her husband's pay and will let her select the finest silk handkerchief in the Hudson's Bay store for a present." In about three minutes her Cree eloquence died a 
natural death; she put a shawl on her head and stepped toward the door without looking at me. Rob nodded to me, and signed to go to the Hudson's Bay store; by which I inferred that the case was won; we were going now to select the present. To my amazement she turned from all the bright-coloured goods and selected a large black silk handkerchief.

The men tell me it is always so now; fifty years ago every woman wanted red things. Now all want black; and the traders who made the mistake of importing red have had to import dyes and dip them all.

Jiarobia, or, as we mostly call him, "Rob," proved a most amusing character as well as a "good man" and the reader will please note that nearly all of my single help were "good men." Only when I had a crowd was there trouble. His store of anecdote was unbounded and his sense of humour ever present, if broad and simple. He talked in English, French, and Cree, and knew a good deal of Chipewyan. Many of his personal adventures would have fitted admirably into the Decameron, but are scarcely suited for this narrative. One evening he began to sing, I listened intently, thinking maybe I should pick up some ancient chanson of the voyageurs or at least a woodman's "Come-all-ye." Alas! it proved to be nothing but the "Whistling Coon."

Which reminds me of another curious experience at the village of Fort Smith. I saw a crowd of the Indians about a lodge and strange noises proceeding therefrom. When I went over the folk made way for me. I entered, sat down, and found that they were 
crowded around a cheap gramophone which was hawhing, spitting and sereeching some awful rag-time music and nigger jigs. I could forgive the traders for bring-

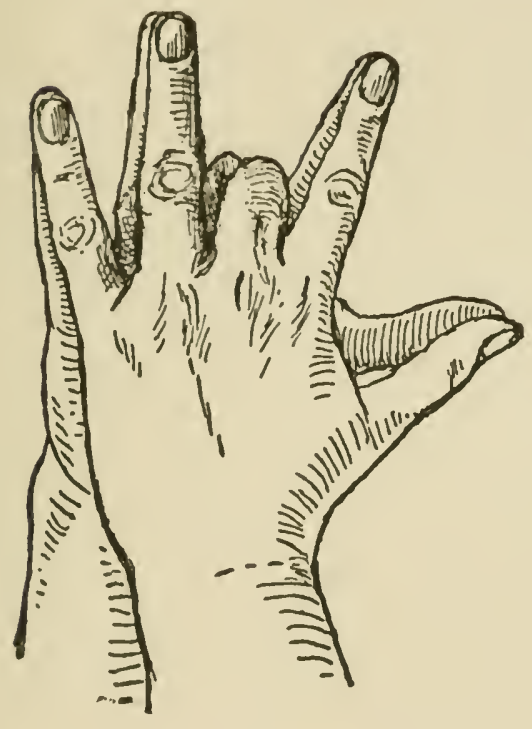
ing in the gramophone, but why, oh, why, did they not bring some of the simple world-wide human songs which could at least have had an educational effect? The Indian group listened to this weird instrument with the profoundest gravity. If there is anything inherently comic in our low comies it was entirely lost on them.

One of Rob's amusing fireside tricks was thus: $\mathrm{He}$ put his hands together, so: (illustration). "Now de tumbs is you and your fader, de first finger is you and your mudder, ze next is you and your sister, ze little finger is you and your brudder, ze ring finger is you and your sweetheart. You and your fader separate easy, like dat; you and your brudder like dat, you and your sister like dat, dat's easy; you and your mudder like dat, dat's not so easy; but you and your sweetheart cannot part widout all everything go to hell first." 
Later, as we passed the American who lives at Fort McMurray, Jiarobia said to me: "Dat man is the biggest awful liar on de river. You should hear him talk. 'One day,' he said, 'dere was a big stone floating up de muddy river and on it was tree men, and one was blind and one was plumb naked and one had no arms nor legs, and de blind man he looks down on bottom of river an see a gold watch, an de cripple he reach out and get it, and de naked man he put it in his pocket.' Now any man talk dat way he one most awful liar, it is not possible, any part, no how." 


\section{CHAPTER XLIV}

\section{THE RIVER}

Now we resumed our daily life of tracking, eating, tracking, camping, tracking, slecping. The weather had continued fine, with little change ever since we left Resolution, and we were so hardened to the life that it was pleasantly monotonous.

How different now were my thoughts compared with those of last Spring, as I first looked on this grent river.

When we had cmbarked on the leaping, boiling, muddy Athabaska, in this frail canoe, it had seemed a foolhardy enterprise. How could such a craft ride such a stream for 2,000 miles? It was like a mouse mounting a monstrous, untamed, plunging and rearing horse. Now we set out each morning, familiar with stream and our boat, having no thought of langer, and viewing the water, the same turbid flood, as our servant. Even as a skilful tamer will turn the wildest horse into his willing slave, so have we conquered this river and made it the bearer of our burdens. So I thought and wrote at the time; but the wise tamer is ever alert, never lulled into false security. He knows that a heedless move may turn his steed into a deadly, dangerous monster. We had our lesson to learn.

That night (October 15) there was a dull yellow sunset. The morning came with a strong north wind and rain that turned to snow, and with it great flocks 
of birds migrating from the Athabaska Lake. Many rough-legged Hawks, hundreds of small land birds, thousands of Snow-birds in flocks of 20 to 200, myriads of Ducks and Geese, passed over our heads going southward before the frost. About 8.30 the Geese began to pass in ever-increasing flocks; between 9.45 and $10 \mathrm{I}$
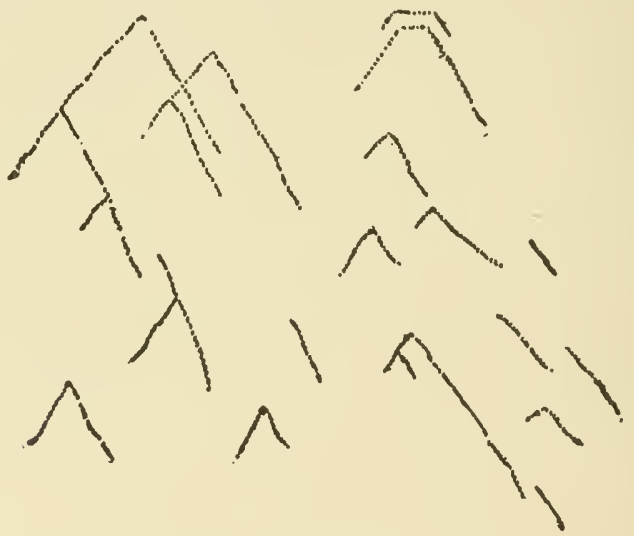

Flocks of Snow-Geese passing southward

counted 114 flocks averaging about 30 each (5 to 300 ) and they kept on at this rate till 2 P. M. This would give a total of nearly 100,000 Geese. It was a joyful thing to see and hear them; their legions in flight array went stringing high aloft, so high they looked not like Geese, but threads across the sky, the cobwebs, indeed, that Mother Carey was sweeping away with her north-wind broom. I sketched and counted flock after flock with a sense of thankfulness that so many were left alive. Most were White Geese, but a twentieth, perhaps, were Honkers. 
The Ducks began to pass orer about noon, and became more numerous than the Geese as they went on.

In the midst of this myriad procession, as though they were the centre and cause of all, were two splendid White Cranes, bugling as they flew. Later that day we saw another band, of three, but these were all; their race is nearly run.

The full moon was on and all night the wild-fowl flew. The frost was close behind them, sharp and sudden. Next morning the ponds about us had ice an inch thick and we heard of it three inches at other places.

But the sun came out gloriously and when at ten we landed at Fort MeMurray the day was warm and perfect in its autumnal peace.

Miss Gordon, the postmaster, did not recognise us at first. She said we all looked "so much older, it is always so with folks who go north."

Next morning we somehow left our tent behind. It was old and of little value, so we did not go back, and the fact that we never really needed it speaks much for the sort of weather we had to the end of the trip.

A couple of Moose (cow and calf) crossed the river ahead of us, and Billy went off in hot pursuit; but saw no more of them.

Tracks of animals were extremely abundant on the shore here. Large Wolves became quite numerous, evidently we were now in their country. Apparently they had killed a Moose, as their dung was full of Moose hair. 
We were now in the Canyon of the Athabaska and from this on our journey was a fight with the rapids. One by one my skilful boatmen negotiated them; either we tracked up or half unloaded, or lancled and portaged, but it was hard and weary work. My journal entry for the night of the 18th runs thus:

"I am tired of troubled waters. All day to-day and for five days back we have been fighting the rapids of this fierce river. My place is to sit in the canoe-bow with a long pole, glancing here and there, right, left, and ahead, watching ever the face of this snarling: river; and when its curling green lips apart betray a yellow brown gleam of deadly teeth too near, it is my part to ply with might and main that pole, and push the frail canoe aside to where the stream is in milder, kindlier mood. Oh, I love not a brawling river any more than a brawling woman, and thoughts of the broad, calm Slave, with its majestic stretches of level flood, are now as happy halcyon memories of a bright and long-gone past."

My men were skilful and indefatigable. One by one we met the hard rapids in various ways, mostly by portaging, but on the morning of the 19th we came to one so small and short that all agreed the canoe could be forced by with poles and track-line. It looked an insignificant ripple, no more than a fish might make with its tail, and what happened in going up, is recorded as follows: 


\section{CHAPTER XLV}

\section{THE RIVER SHOWS I'TS TEETH}

"Oct. 20, 1907.-Athabaska River. In the Canyon. This has been a day of horrors and mercies. We left the camp early, 6.55-long before sunrise, and portaged the first rapid. About 9 we came to the middle rapid; this Billy thought we could track up, so with two ropes he and Rob were hauling us, I in bow, Preble in stern; but the strong waters of the middle part whirled the canoe around suddenly, and dashed her on a rock. There was a crash of breaking timber, a roar of the flood, and in a moment Preble and I and all the stuff were in the water.

"'My journals,' I shouted as I went down, and all the time the flood was boiling in my ears my thought was, 'My journals,'-'my journals.'

"The moment my mouth was up again above the water, I bubbled out, 'My journals, - save my journals,' then struck out for the shore. Now I saw Preble langing on to the canoe and trying to right it. His face was calm and unchanged as when setting a mousetrap. 'Never mind that, save yourself,' I called out; he made no response, and, after all, it was safest to hang on to the canoe. I was swept into a shallow place at once, and got on my feet, then gained the shore. 
"'My journals—save them first!' I shouted to the two boys, and now remembered with horror, how, this very morning, on account of portaging, I had for the first time put all three journals in the hand-bag that had disappeared, whereas the telescope that used to hold two of them, was floating high. It is the emergency that proves your man, and I learned that day I had three of the best men that ever boarded a boat. A glance showed Preble in shallow water coolly hauling in the canoe.

"Rob and Billy bounded along the rugged shores, from one ice-covered rock to another, over piles of drift logs and along steep ledges they went; like two mountain goats; the flood was spotted with floating things, but no sign of the precious journal-bag. Away out was the grub-box; square and high afloat, it struck a reef. 'You save the grub,' yelled Billy above the roaring, pitiless flood, and dashed on. I knew Billy's head was cool and clear, so I plunged into the water, ice-cold and waist deep-and before the merciless one could snatch it along, I had the grub-box safe. Meanwhile Rob and Billy had danced away out of sight along that wild canyon bank. I set out after them. In some eddies various articles were afloat, a cocoa tin, a milk pot, a bag of rare orchids intended for a friend, a half sack of flour, and many little things I saved at cost of a fresh wetting each time, and on the bank, thrown hastily up by the boys, were such bundles as they had been able to rescue.

"I struggled on, but the pace was killing. They were young men and dog-runners; I was left behind 
and was getting so tired now I could not keep warm; there was a keen frost and I was wet to the skin. The chance to rescuc other things came again and again. Twelve times did I plunge into that deadly cold river, and so gathered a lot of small truck. Then knowing I could do little more, and realising that everything man could do would be done without me, turned back reluctantly. Preble passed me at a run; he had left the canoe in a good place and had saved some bedding.

"Have you seen my journal-bag?' He made a quick gesture down the river, then dashed away. Alas! I knew now, the one irreplaceable part of our cargo was deep in the treacherous flood, never to be seen again.

"At the canoe I set about making a fire; there was no axe to cut kindling-wood, but a birch tree was near, and a pile of shredded birch-bark with a lot of dry willow on it made a perfect fire-lay; then I opened my waterproof matchbox. Oh, horrors! the fifteen matches in it were damp and soggy. I tried to dry them by blowing on them; my frozen fingers could scarcely hold them. After a time I struck one. It was soft and useless; another and another at intervals, till thirteen; then, despairing, I laid the last two on a stone in the weak sunlight, and tried to warm myself by gathering firewood and moving quickly, but it seemed uselessa very death chill was on me. I have often lighted a fire with rubbing-sticks, but I needed an axe, as well as a buckskin thong for this, and I had neither. I looked through the baggage that was saved, no matches 
and all things dripping wet. I might go three miles down that frightful canyon to our last camp and maylue get some living coals. But no! mindful of the forestry laws, we had as usual most earefully extinguished the fire with buckets of water, and the clothes were freezing on my back. I was tired out, teeth chattering. Then came the thought, Why despair while two matches remain? I struck the first now, the fourteenth, and, in spite of dead fingers and the sizzly, doubtful match, it cracked, blazed, and then, oh blessed, blessed birch bark! - with any other tinder my numbed hands had surely failed-it blazed like a torch, and warmth at last was mine, and outward comfort for a house of gloom. "The boys, I knew, would work like heroes and do their part as well as man could do it, my work was right here. I gathered all the things along the beach, made great racks for drying and a mighty blaze. I had no pots or pans, but an aluminum bottle which would serve as kettle; and thus I prepared a meal of such things as were saved-a scrap of pork, some tea and a soggy mass that once was pilot bread. Then sat down by the fire to spend five hours of growing horror, 175 miles from a settlement, canoe smashed, guns gone, pots and pans gone, specimens all gone, half our bedding gone, our food gone; but all these things were nothing, compared with the loss of my three precious journals; 600 pages of observation and discovery, geographical, botanical, and zoological, 500 drawings, valuable records made under all sorts of trying circumstances, discovery and compass survey of the beautiful Nyarling River, compass survey of the two great 
northern lakes, discovery of two great northern rivers, many lakes, a thousand things of interest to others and priceless to me-my summer's work-gone; yes, I could bear that, but the three chapters of life and thought irrevocably gone; the magnitude of this calamity was erushing. Oh, Gorl, this is the most awful blow that could have fallen at the end of the six months' trip.

"The hours went by, and the gloom grew deeper, for there was no sign of the boys. Never till now did the thought of danger enter my mind. Had they been too foolhardy in their struggle with the terrible stream? Had they, too, been made to feel its power? My guess was near the truth; and yet there was that awful river unchanged, glittering, surging, beautiful, exactly as on so many days before, when life on it had seemed so bright.

"At three in the afternoon, I saw a fly crawl down the rocks a mile away. I fed the fire and heated up the food and tea. In twenty minutes I could sce that it was Rol, but both his hands were empty. 'If they' had found it,' I said to myself, 'they would send it back first thing, and if he had it, he would swing it aloft,' Yet no, nothing but a shiny tin was in his hands and the blow had fallen. The suspense was over, anyway. I bowed my head, "We have done what we could.'

"Rob came slowly up, worn out. In his hand a tin of baking-powder. Across his breast was a canvas band. He tottered toward me, too tired to speak in answer to my unspoken question, but he turned and 
there on his back was the canvas bag that held the labour of all these long toilsome months.

"'I got 'em all right,' he managed to say, smiling in a weak way.

"And the boys?"

"'All right now.'

"'Thank God!' I broke down, and wrung his hand; 'I won't forget,' was all I could say. Hot tea revived him, loosened his tongue, and I heard the story.

"'I knew,' he said, 'what was first to save when I seen you got ashore. Me and Billy we run like crazy, we see dat bag 'way out in the deep strong water. De odder tings came in de eddies, but dat bag it keep 'way out, but we run along de rocks; after a mile it came pretty near a point, and Billy, he climb on a rock and reach out, but he fall in deep water and was carried far, so he had to swim for his life. I jump on rocks anoder mile to anoder point; I got ahead of de bag, den I get two logs, and hold dem between my legs for raft, and push out; but dat dam river he take dem logs very slow, and dat bag very fast, so it pass by. But Billy he swim ashore, and run some more, and he make a raft; but de raft he stick on rock, and de bag he never stick, but go like hell.

"Den I say, "Here, Billy, you give me yo" sash," and I run tree mile more, so far I loss sight of dat bag and make good raft. By'mebye Billy he come shouting and point, I push out in river, and paddle, and watch, and sure dere come dat bag. My, how he travel! far out now; but I paddle and push hard and bump he came at raft and I grab him. Oh! maybe I 
warn't glad! ice on river, frost in air, 14 mile run on snowy rocks, but I no care, I bet I make dat boss glad when he see me."

"Glad! I never felt more thankful in my life! My heart swelled with gratitude to the brave boys that had leaped, scrambled, slidden, tumbled, fallen, swum or climbed over those 14 perilous, horrible miles of icy rocks and storm-piled timbers, to save the books that, to them, seemed of so little value, but which they yet knew were, to me, the most precious of all my things. Guns, cameras, food, tents, bedding, dishes, were trifling losses, and the horror of that day was turned to joy by the crowning mercy of its close.

"I won't forget you when we reach the Landing, Rob!' were the meagre words that rose to my lips, but the tone of voice supplied what the words might lack. And I did not forget him or the others; and Robillard said afterward, 'By Gar, dat de best day's work I ever done, by Gar, de time I run down dat hell river after dem dam books!'” 


\section{CHAPTER XLVI}

\section{BRIGH'T'AGAIN}

In an hour the other men came back. The rest of the day we put in drying the things, especially our bedding. We used the aluminum bottle, and an old meat tin for kettle; some bacon, happily saved, was fried on sticks, and when we turned in that night it was with light and thankful hearts, in spite of our manifold minor losses.

Morning dawned bright and beautiful and keen. How glorious that surging river looked in its noble canyon; but we were learning thoroughly that noble scenery means dangerous travel-and there was much noble scenery ahead; and I, at least, felt much older than before this upset.

The boys put in a couple of hours repairing the canoe. then they studied the river in hopes of recovering the guns. How well the river-men seemed to know it! Its every ripple and curl told them a story of the bottom and the flood.

"There must be a ledge there," said Billy, "just where we upset. If the guns went down at once they are there. If they were carried at all, the bottom is smooth to the second ledge and they are there." He pointed a hundred yards away.

So they armed themselves with grappling-poles that had nails for claws. Then we lowered Rob in 
the eanoe into the rapid and held on while he fished above the ledge.

"I tink I feel 'em," said Rob, again and again, but could not bring them up. Then Billy tried.

"Yes, they are there." But the current was too fierce and the hook too poor; he could not hold them.

Then I said: "There is only one thing to do. A man must go in at the end of the rope; maybe he can reach down. I'll never send any man into such a place, but I'll go myself."

So I stripped, padded the track-line with a towel and put it around my waist, then plunged in. Ouch! it was cold, and going seven miles an hour. The boys lowered me to the spot where I was supposed to dive or reach down. It was only five feet deep, but, struggle as I might, I could not get even my arm down. I ducked and dived, but I was held in the surface like a pennant on an air-blast. In a few minutes the icy flood had robbed me of all sensation in my limbs, and showed how impossible was the plan, so I gave the signal to haul me in; which they did, nearly cutting my body in two with the rope. And if ever there was a grovelling fire-worshipper, it was my frozen self when I landed.

Now we tried a new scheme. A tall spruce on the shore was leaning over the place; fifty feet out, barely showing, was the rock that wrecked us. We cut the spruce so it fell with its butt on the shore, and lodged against the rock. On this, now, Rob and Billy walked out and took turns grappling. Juck was with Rob. 
In a few minutes he triumphantly hauled up the rifle and a little later the shotgun, none the worse.

Now, we had saved everything except the surplus provisions and my little camera, trifling matters, indeed; so it was with feelings of triumph that we went on south that day.

In the afternoon, as we were tracking up the last part of the Boiler Rapid, Billy at the bow, Rob on the shore, the line broke, and we were only saved from another

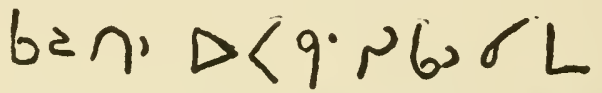 \\ Gor-dn ouspa-que=se-kan ne=ma Gordon "flour a his}

dreadful disaster by Billy's nerve and quickness; for he fearlessly leaped overboard, had the luck to find bottom, and held the canoe's head with all his strength. The rope was mended and a safe way was found. That time I realized the force of an Indian reply to a trader who sought to sell him a cheap rope. "In the midst of a rapid one does not count the cost of the line."

At night we camped in a glorious red sunset, just above the Boiler Rapid. On the shore was a pile of flour in sacks, inscribed in Cree, "Gordon his flour."

Here it was, the most prized foreign product in the country, lying unprotected by the highway, and no man seemed to think the owner foolish. Whatever else these Indians are, they are absolutely honest. 
The heavenly weather of the Indian Summer was now upon us. We had left all storms and frost behind, and the next day, our final trouble, the lack of food, was ended. A great steamer hove in sight-at least it looked like a steamer-but, steadily coming on, it proved a scow with an awning and a stove on it. The boys soon recognised the man at the bow as William Gordon, trader at Fort MeMurray. We hailed him to stop when he was a quarter of a mile ahead, and he responded with his six sturdy oarsmen; but such was the force of the stream that he did not reach the shore till a quarter-mile below us.

"Hello, boys, what's up?" He shouted in the brotherly way that all white men seem to get when meeting another of their race in a savage land.

"Had an upset and lost all our food."

"Ho! that's easy fixed." Then did that generous man break open boxes, bales, and packages and freely gave without a stint, all the things we needed: kettles, pans, sugar, oatmeal, beans, jam, etc.

"How are you fixed for whiskey?" he asked, opening his own private, not-for-sale supply.

"We have none and we never use it," was the reply. Then I fear I fell very low in the eyes of my crew.

"Never use it! Don't want it! You must be pretty damn lonesome in a country like this," and he seemed quite unable to grasp the idea of travellers who would not drink.

Thus the last of our troubles was ended. Thenceforth the journey was one of warm, sunny weather and pleasant travel. Each night the sun went down in 
red and purple fire; and each morning rose in gold on a steel-blue sky. There was only one bad side to this, that was the constant danger of forest fire. On leaving each camp-we made four every day-I put the fire out with plenty of water, many buckets. Rob thought it unnecessary to take so much trouble. But great clouds of smoke were seen at several reaches of the river, to tell how dire it was that other campers had not done the same. 


\section{CHAPTER XLVII}

\section{WHEN NATURE SMILED}

IT seems a law that every deep valley must be next a high mountain. Our sorrows ended when we quit the canyon, and then, as though in compensation, nature crammed the days with the small joys that seem so little and mean so much to the naturalist.

Those last few days, unmarred of the smallest hardship, were one long pearl-string of the things I came for - the chances to see and be among wild life.

Each night the Coyote and the Fox came rustling about our camp, or the Weasel and Woodmouse scrambled over our sleeping forms. Each morning at gray dawn, gray Wiskajon and his matc-always a paircame wailing through the woods, to flirt about the camp and steal scraps of meat that needed not to be stolen, being theirs by right. Their small cousins, the Chicadees, came, too, at breakfast time, and in our daily travelling, Ruffed Grouse, Ravens, Pine Grosbeaks, Bohemian Chatterers, Hairy Woodpeckers, Shrikes, Tree-sparrows, Linnets, and Snowbirds enlivened the radiant sunlit scene.

One afternoon I heard a peculiar note, at first like the "cheepy-teet-leet" of the Pine Grosbeak, only louder and more broken, changing to the jingling of Blackbirds in spring, mixed with some Bluejay "jay-jays," 
and a Robin-like whistle; then I saw that it came from a Northern Shrike on the bushes just ahead of us. It flew off much after the manner of the Summer Shrike, with flight not truly undulatory nor yet straight, but flapping half a dozen times - then a pause and repeat. He would dive along down near the ground, then up with a fine display of wings and tail to the next perch selected, there to repeat with fresh variations and shrieks, the same strange song, and often indeed sang it on the wing, until at last he crossed the river.

Sometimes we rode in the canoe, sometimes tramped along the easy shore. Once I came across a Great Horned Owl in the grass by the water. He had a fish over a foot long, and fiew with difficulty when he bore it off. Another time I saw a Horned Owl mobbed by two Wiskajons. Spruce Partridge as well as the Ruffed species became common: one morning some of the former marched into camp at breakfast time. Rob called them "Chickens"; farther south they are called "Fool Hens," which is descriptive and helps to distinguish them from their neighbours-the "Sage Hens." Frequently now we heard the toy-trumpeting and the clack of the Pileated Woodpecker or Cock-of the-Pines, a Canadian rather than a Hudsonian species. One day, at our three o'clock meal, a great splendid fellow of the kind gave us a thrill. "Clack-clackclack," we heard him coming, and he bounded through the air into the trees over our camp. Still uttering his loud "Clack-clack-clack," he swung from tree to tree in one long festoon of flight, spread out on the up- 
swoop like an enormous black butterfly with whitestarred wings. "Clack-clack-clack," he stirred the echoes from the other shore, and ignored us as he swooped and clanged. There was much in his song of the Woodpecker tang; it was very nearly the springtime "cluck-cluck" of a magnified Flicker in black; and I gazed with open mouth until he thought fit to bound through the air to another woods. This was my first close meeting with the King of the Woodpeckers; I long to know him better.

Mammals, too, abounded, but we saw their signs rather than themselves, for most are nocturnal. The Redsquirrels, so scarce last spring, were quite plentiful,

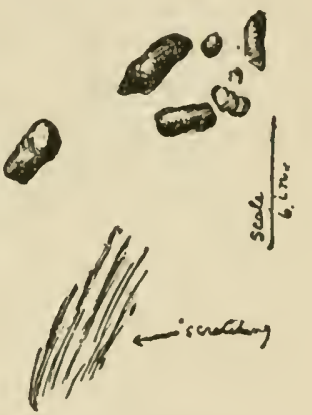

Scatology of Wolf and the beach at all soft places showed abundant trace of Weasels, Chipmunks, Foxes, Coyotes, Lynx, Wolves, Moose, Caribou, Deer. One Wolf track was of special interest. It was $5 \frac{1}{2}$ inches long and travelling with it was the track of a small Wolf; it vividly brought back the days of Lobo and Blanca, and I doubt not was another case of mates; we were evidently in the range of a giant Wolf who was travelling around with his wife. Another large Wolf track was lacking the two inner toes of the inner hind foot, and the hind foot pads were so faint as to be lost at times, although the toes were deeply impressed in the mud. This probably meant that he had been in a trap and was starved to a skeleton. 
We did not see any of these, but we did see the postgraduate evidences of their diet, and were somewhat surprised to learn that it included much fruit, especially of the uva-ursi. We also saw proof that they had eaten part of a Moose; probably they had killed it.

Coyote abounded now, and these we saw from time to time. Once I tramped up within thirty feet of a

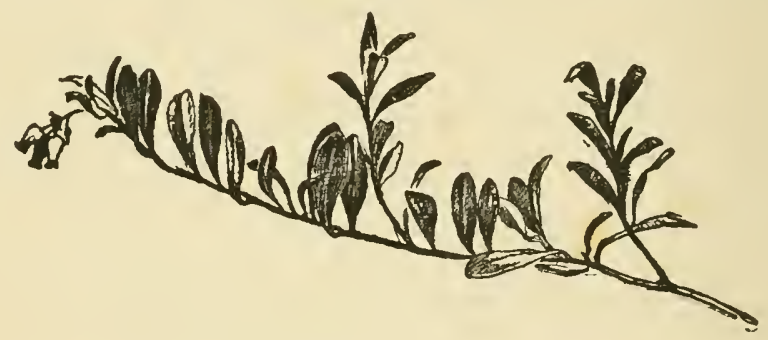

Bear-berry, or Uva-ursi

big fellow who was pursuing some zoological studies behind a log. But again the incontrovertible-postmortem-evidence of their food habits was a surprisethe bulk of their sustenance now was berries, in one case this was mixed with the tail hairs-but no body hairs - of a Chipmunk. I suppose that Chipmunk escaped minus his tail. There was much evidence that all those creatures that can eat fruit were in good condition, but that flesh in its most accessible form-rabbits-was unknown, and even next best thing - the mice-were too scarce to count; this weighed with especial force on the Lynxes; they alone seemed unable to eke out with fruit. The few we saw were starving and at our camp of the 28th we found the wretched body of one that was dead of hunger. 
On that same night we had a curious adventure with a Weasel.

All were sitting around the camp-fire at bed-time, when I heard a distinct patter on the leaves. "Something coming," I whispered. All held still, then out of the gloom came bounding a snow-white Weasel. Preble was lying on his back with his hands clasped behind his head and the Weasel fearlessly jumped on my colleague's broad chest, and stood peering about.

In a flash Preble's right elbow was down and held the Weasel prisoner, his left hand coming to assist. Now, it is pretty well known that if you and a Weasel grab each other at the same time he has choice of holds.

"I have got him," said Preble, then added feelingly, "but he got me first. Suffering Moses! the little cuss is grinding his teeth in deeper."

The muffled sereaming of the small demon died away as Preble's strong left hand crushed out his life, but as long as there was a spark of it remaining, those desperate jaws were grinding deeper into his thumb. It scemed a remarkably long affair to us, and from time to time, as Preble let off some fierce ejaculation, one of us would ask, "Hello! Are you two still at it," or, "How are you and your friend these times, Preble?"

In a few minutes it was over, but that creature in his fury seemed to have inspired himself with lock-jaw, for his teeth were so driven in and double-locked, that I had to pry the jaws apart before the hand was free. The Weasel may now be seen in the American Museum, and Preble in the Agricultural Department at Washington, the latter none the worse. 
306

\section{ARC'TIC PRAIRIES}

So wore away the month, the last night came, a night of fireside joy at home (for was it not Hallowe'en?), and our celebration took the form of washing, shaving, mending clothes, in preparation for our landing in the morning. 


\section{CHAPTER XLVIII}

\section{THE END}

AlL that night of Hallowe'en, a Partridge drummed near my untented couch on the balsam boughs. What a glorious sound of woods and life triumphant it seemed; and why did he drum at night? Simply because he had more joy than the short fall day gave him time to express. He secmed to be beating our march of victory, for were we not in triumph coming home? The gray firstlight came through the trees and showed us lying each in his blanket, covered with leaves, like babes in the woods. The gray Jays came wailing through the gloom, a faroff Cock-of-the-Pines was trumpeting in the lovely, unplagued autumn woods; it seemed as though all the very best things in the land were assembled and the bad things all left out, so that our final memories should have no evil shade.

The scene comes brightly back again, the sheltering fir-clad shore, the staunch canoe skimming the river's tranquil reach, the water smiling round her bow, as we push from this, the last of full five hundred camps.

The dawn fog lifts, the river sparkles in the sun, we round the last of a thousand headlands. The little frontier town of the Landing swings into view once more-what a metropolis it seems to us now!-The Ann Seton lands at the spot where six months ago she 
had entered the water. Now in quick succession come the thrills of the larger life-the letters from home, the tclegraph office, the hearty good-bye to the brave riverboys, and my long canoe-ride is over.

I had held in my heart the wanderlust till it swept me away, and sent me afar on the back trail of the north wind; I have lived in the mighty boreal forest, with its Red-men, its Buffalo, its Moose, and its Wolves; I have seen the Great Lone Land with its endless plains and prairies that do not know the face of man or the crack of a rifle; I have been with its countless lakes that re-echo nothing but the wail and yodel of the Loons, or the mournful music of the Arctic Wolf. I have wandered on the plains of the Musk-ox, the home of the Snowbird and the Caribou. These were the things I had burned to do. Was I content? Content!! Is a man ever content with a single sip of joy long-dreamed of?

Four years have gone since then. The wanderlust was not stifled any more than a fire is stifled by giving it air. I have taken into my heart a longing, given shape to an ancient instinct. Have I not found for myself a kingdom and become a part of it? My reason and my heart say, "Go back to see it all." Grant only this, that I gather again the same brave men that manned my frail canoe, and as sure as life and strength continue I shall go. 



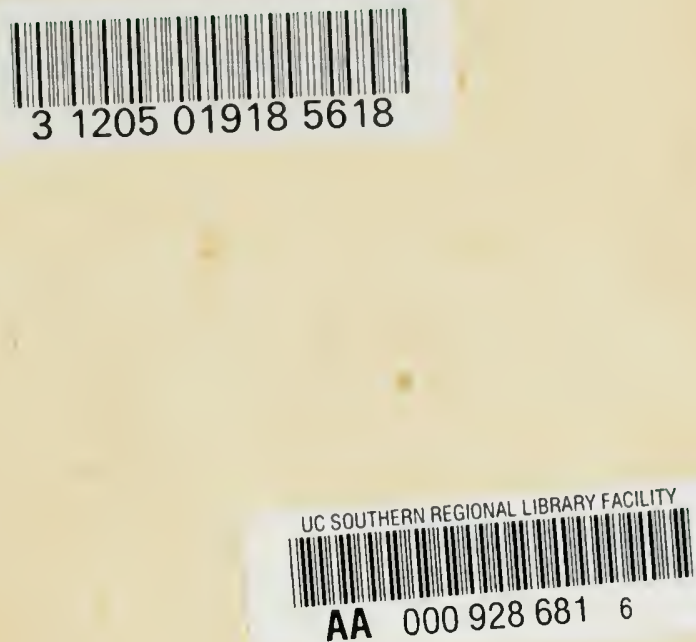
